Energy Systems Environmental Restoration Program

Clinch River Environmental Restoration Program

\title{
White Oak Creek Embayment Site Characterization and Contaminant Screening Analysis
}

\author{
B. G. Blaylock \\ C. J. Ford \\ M. L. Frank \\ F. O. Hoffman \\ L. A. Hook
}

Date Issued-January 1993

\author{
Prepared by \\ Environmental Sciences Division \\ Oak Ridge National Laboratory \\ ESD Publication 3821 \\ Prepared for \\ U.S. Department of Energy
}

Office of Environmental Restoration and Waste Management under budget and reporting codes CD 1072 and EW 20

OAK RIDGE NATIONAL LABORATORY

Oak Ridge, Tennessee 37831-6285

managed by

MARTIN MARIETTA ENERGY SYSTEMS, INC.

for the

U.S. DEPARTMENT OF ENERGY under contract DE-AC05-84OR21400 


\section{CONTENTS}

ACKNOWLEDGEMENTS $\ldots \ldots \ldots \ldots \ldots \ldots \ldots \ldots \ldots \ldots \ldots \ldots \ldots \ldots \ldots \ldots \ldots \ldots$ xiii

EXECUTIVE SUMMARY $\ldots \ldots \ldots \ldots \ldots \ldots \ldots \ldots \ldots \ldots \ldots \ldots \ldots \ldots \ldots$

1. SITE CHARACTERIZATION $\ldots \ldots \ldots \ldots \ldots \ldots \ldots \ldots \ldots \ldots \ldots \ldots$

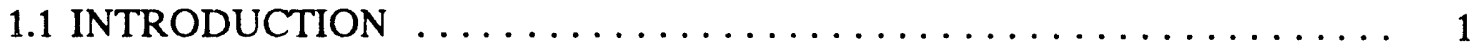

1.1.1 Events Leading to the Interim Ccirective Action . . . . . . . . . 1

1.2 DESCRIPTION OF AREA $\ldots \ldots \ldots \ldots \ldots \ldots \ldots \ldots \ldots \ldots \ldots \ldots \ldots$

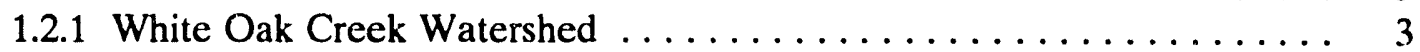

1.2.2 White Oak Lake Dam $\ldots \ldots \ldots \ldots \ldots \ldots \ldots \ldots \ldots \ldots \ldots \ldots$

1.2 .3 White Oak Lake .......................... 5

1.2.4 Inventory of Radionuclides in White Oak Lake Sediments . . . . . . , 7

1.2.5 White Oak Creek Embayment .................. 7

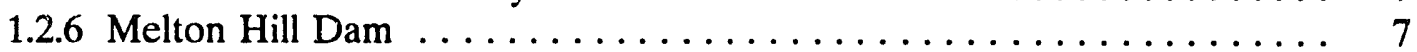

1.3 CONTAMINANTS IN WHITE OAK CREEK EMBAYMENT $\ldots \ldots \ldots \ldots .10$

1.3.1 Radionuclides in White Oak Creek Embayment ............ 10

1.3.2 Historical Radiological Data . . . . . . . . . . . . . . . . 10

1.3.3 Recent Radiological Data . . . . . . . . . . . . . . . . . 12

1.3.4 Organic Contaminants in White Oak Creek Embayment Sediments . . . 18

1.3.5 Inorganic Contaminants in White Oak Creek Embayment Sediments . . 19

1.3.6 Classification of Potential Waste from

White Oak Creek Embayment Sediments ... . . . . . . . . . . . 20

1.3.7 Water Analyses .......................... 22

1.3.8 Aquatic Biota in White Oak Creek Embayment ............ 22

1.3.9 External Radiation Survey ..................... 23

1.3.10 Source of ${ }^{137} \mathrm{Cs}$ in White Oak Creek Embayment Sediments . . . . . . 24

2. SCREENING OF CONTAMINANTS IN THE WHITE OAK CREEK

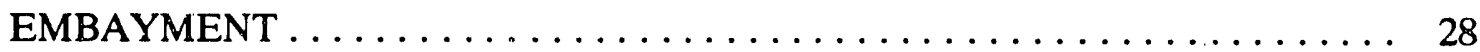

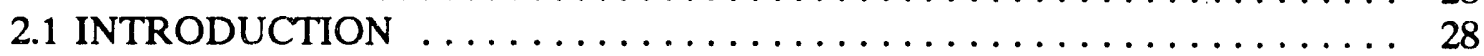

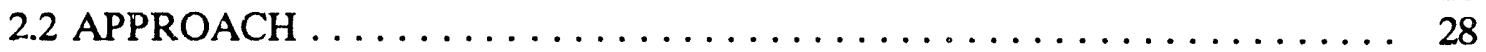

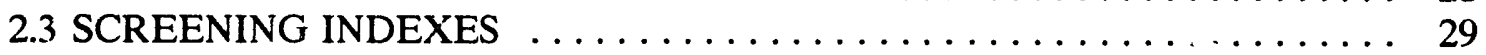

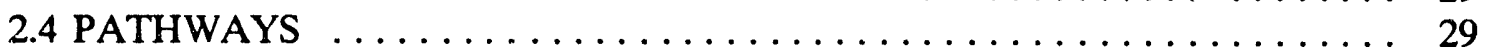

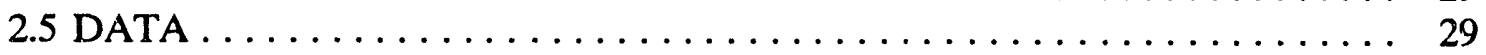

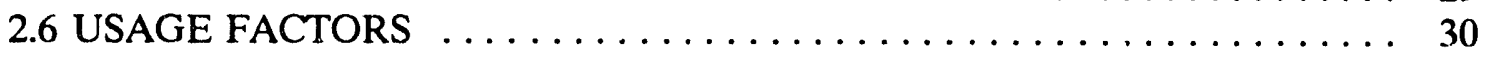

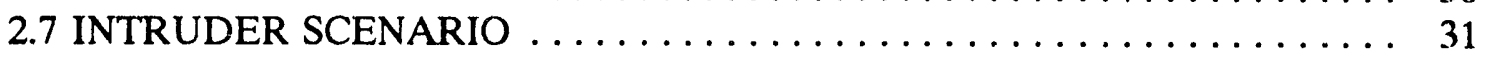

2.8 SCREENING CRITERIA $\ldots \ldots \ldots \ldots \ldots \ldots \ldots \ldots \ldots \ldots \ldots \ldots \ldots \ldots$

3. CONTAMINANT SCREENING RESULTS $\ldots \ldots \ldots \ldots \ldots \ldots \ldots \ldots \ldots \ldots$

3.1 DETECTABLE CONTAMINANTS $\ldots \ldots \ldots \ldots \ldots \ldots \ldots \ldots \ldots \ldots \ldots$

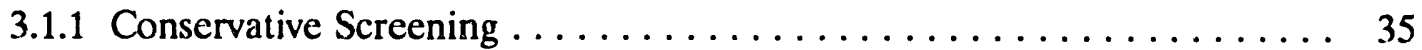

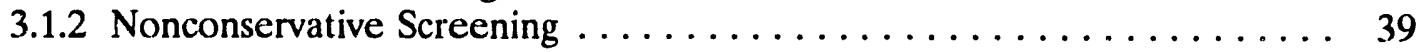

3.1.3 Intruder Scenario . . . . . . . . . . . . . . . . . . . . 41

3.2 NONDETECTABLE CONTAMINANTS $\ldots \ldots \ldots \ldots \ldots \ldots \ldots \ldots \ldots$

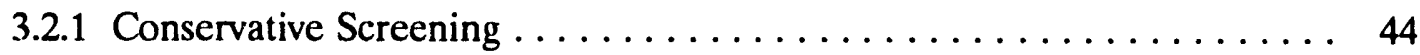


3.2 .2 Nonconservative Screening . . . . . . . . . . . . . . . . 44

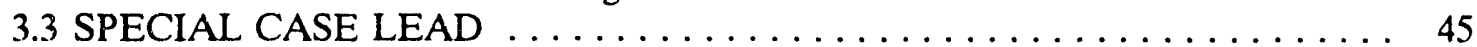

3.4 NONCLASSIFIED CONTAMINANTS $\ldots \ldots \ldots \ldots \ldots \ldots \ldots \ldots$

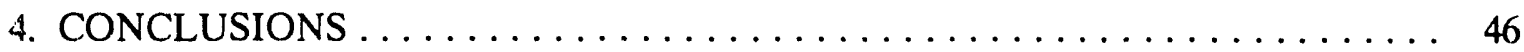

REFERENCES $\ldots \ldots \ldots \ldots \ldots \ldots \ldots \ldots \ldots \ldots \ldots \ldots \ldots \ldots \ldots \ldots$

APPENDIX A: Concentrations of Radionuclides in White Oak

Creek Embayment Core Samples Collected in $1977 \ldots \ldots \ldots \ldots \ldots \ldots \ldots$

APPENDIX B: Concentrations of Contaminants

in TVA Core Samples Collected in White

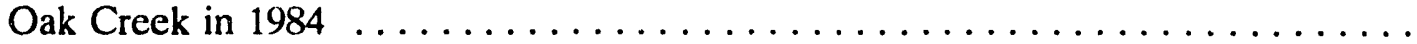

APPENDIX C: Concentrations of Inorganic and Organic

Contaminants in White Oak Creek Embayment Core

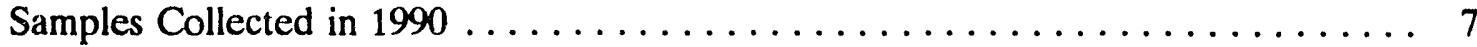

APPENDIX D: Concentrations of Radionuclides in White Oak

Creek Embayment Surface Sediment Samples

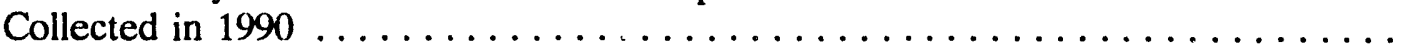

APPENDIX E: Summary of National Pollutant Discharge

Elimination System (NPDES) Data Collected at White Oak Creek

Dam from January 1989 to September 1990 .

APPENDIX F: Summary of Contaminant Concentrations

in White Oak Creek Embayment Water Samples

Collected in 1990

APPENDIX G: Summary of Contaminant Concentrations

in White Oak Creek Embayment Fish Collected in 1990

APPENDIX H: Conservative Screening of the Detectable

Contaminants Data Base for Carcinogens and

Noncarcinogens

APPENDIX I: Nonconservative Screening of the Detectable

Contaminants Data Base for Carcinogens and

Noncarcinogens

APPENDIX J: Screening of the Intruder Scenario for Detected

Carcinogens and Noncarcinogens

APPENDIX K: Conservative Screening of the Nondetectable

Contaminants Data Base for Carcinogens

and Noncarcinogens 
APPENDIX L: Nonconservative seening of the Nondetectable

Contaminants Data Base for Carc ... gens and

Noncarcinogens ................................. 127

APPENDIX M: Classification of Sediment Waste from White Oak

Creek Embayment by Toxicity Characteristic Leachate

Procedure .................................... 133 


\section{FIGURES}

1.1 Profile of ${ }^{137} \mathrm{Cs}$ concentrations of sediment in core no. $9500 \mathrm{G}$ taken $\sim 50 \mathrm{~m}$ upstream from the mouth of White Oak Creek .............. 2

1.2 The White Oak Creek Watershed including the Oak Ridge National Laboratory and associated waste disposal areas ................ 4

1.3 Graph from a stage-height recorder at the mouth of White Oak Creek .... 8

1.4 Location of historical core sampling sites in WOCE and site of core $9500 \mathrm{G}$ (9500T is split of 9500G), which was collected in June $1990 \ldots \ldots \ldots \ldots . \ldots 11$

1.5 Concentration of ${ }^{137} \mathrm{Cs}$ with depth below the sediment surface for three core

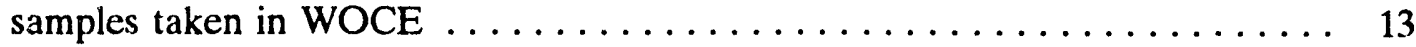

1.6 Location of sediment core sampling sites in WOCE . . . . . . . . 14

1.7 Locations where surface sediment grab samples were collected in 1990 and 1991 from the lower end of WOCE . . . . . . . . . . . . . . . . . . . 16

1.8 Locations where surface sediment grab samples were collected in 1990 and 1991 from the upper end of WOCE . . . . . . . . . . . . . . . . . .

1.9 Profiles of the distribution of arsenic, lead, and mercury by depth in three sediment cores

1.10 Survey of gamma (primarily ${ }^{137} \mathrm{Cs}$ ) radiation exposure rates measured $1 \mathrm{~m}$ above the ground surface along the banks of WOCE when water was at fullpool level

1.11 Survey of gamma (primarily ${ }^{137} \mathrm{Cs}$ ) radiation exposure rates measured $1 \mathrm{~m}$ above the ground surface when the water was at low-pool level ..........

1.12 Survey of gamma (primarily ${ }^{137} \mathrm{Cs}$ ) radiation exposure rates measured $1 \mathrm{~m}$ above the floodplain surface when the water was at low-pool level . . . . . . . .

2.1 Criteria for conservative and nonconservative screening of carcinogens $\ldots \ldots 33$

2.2 Criteria for conservative and nonconservative screening of noncarcinogens .. 34

D.1 Depth profiles for ${ }^{137} \mathrm{Cs}$ in sediment cores taken in transect across the mouth

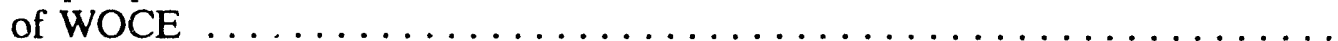

D.2 Depth profiles for ${ }^{137} \mathrm{Cs}$ in sediment cores taken in transect across WOCE

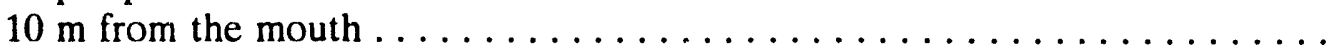


D.3 Depth profiles for ${ }^{137} \mathrm{Cs}$ in sediment cores taken in transect across WOCE $20 \mathrm{~m}$ from the mouth . . . . . . . . . . . . . . . . . .

D.4 Depth profiles for ${ }^{137} \mathrm{Cs}$ in sediment cores taken adjacent to each other at three locations in the embayment

M.1 Locations of core sampling sites near the mouth of WOCE from which samples were collected and screened for inorganic contaminants before subjecting them to the Toxicity Characteristic Leachate Procedure to determine the waste classification of the sediment 


\section{TABLES}

1.1 Estimated discharges of selected radionuclides from White Oak Creek

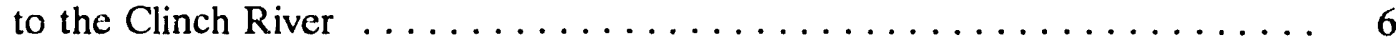

1.2 Historical changes in White Cak Lake $\ldots \ldots \ldots \ldots \ldots \ldots \ldots \ldots$

1.3 Budget of radionuclides (curies) in White Oak Lake sediment . . . . . . 10

1.4 Estimated inventory of various radionuclides in WOCE sediments . . . . . 19

2.1 Values used for contaminant concentrations in conservative and nonconservative screening and intruder scenarios $\ldots \ldots \ldots \ldots \ldots \ldots$

2.2 Usage factors for conservative and nonconservative screening $\ldots \ldots \ldots 31$

3.1 Summary table for conservative screening of detected carcinogens $\ldots \ldots \ldots 36$

3.2 Carcinogens assigned to different screening categories by conservative screening of data base where at least one value or each contaminant was

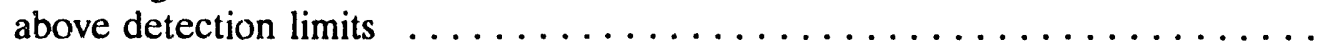

3.3. Summary table for conservative screening of detected noncarcinogens $\ldots \ldots 38$

3.4. Noncarcinogens assigned to different screening categories by conservative screening of data base where at least one value for each contaminant was

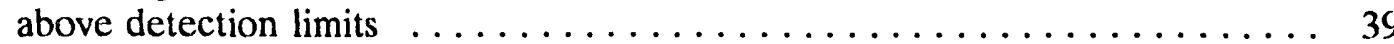

3.5. Summary table for nonconservative screening of detected carcinogens $\ldots \ldots \quad 40$

3.6. Carcinogens assigned to different screening categories by nonconservative screening of data base where at least one value for each contaminant was above detection limits $\ldots \ldots \ldots \ldots \ldots \ldots \ldots \ldots \ldots \ldots \ldots$

3.7. Summary table for nonconservative screening of detected noncarcinogens $\ldots \quad . \quad 42$

3.8. Noncarcinogens assigned to different screening categories by nonconservative screening of data base where at least one value for each contaminant was above detection limits

3.9. Summary table of intruder scenario screening indexes for detected

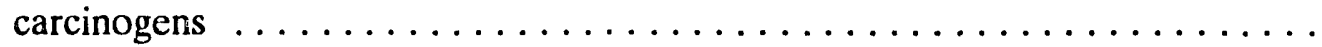

3.10. Summary table of intruder scenario screening indexes for detected

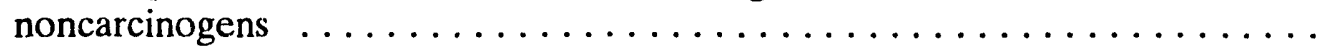


A.1 Summary of radionuclide concentrations in WOCE core samples collected

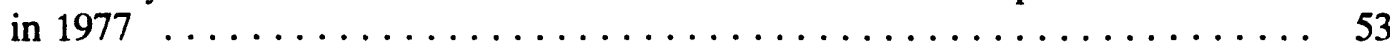

A.2 Radionuclide concentrations in WOCE core samples collected in $1977 \ldots \ldots$. . 54

B.1 Summary of contaminant concentrations in TVA core samples collected in 1984

B.2 Contaminant concentrations in TVA core samples collected in 1984

C.1 Summary of inorganic and organic contaminant concentrations in WOCE core samples collected in 1990

C.2 Summary of inorganic and organic contaminant concentrations in WOCE core samples collected after July $1990 \ldots \ldots \ldots \ldots \ldots \ldots \ldots \ldots \ldots$

D.1 Summary of radionuclide concentrations in WOCE grab samples $\ldots \ldots \ldots 79$

D.2 Radionuclide concentrations in WOCE grab samples $\ldots \ldots \ldots \ldots \ldots \ldots$

D.3 Summary of radionuclide concentrations in WOCE core samples $\ldots \ldots \ldots 82$

D.4 Summary of individual core radionuclide concentrations in WOCE . . . . 83

E.1 Summary of White Oak Creek Dam NPDES and radiological data collected from January 1989 through September 1990 . . . . . . . . . . . . 91

F.1 Summary of inorganic, organic, and radioactive, contaminant concentrations in WOCE water samples collected in $1990 \ldots \ldots \ldots \ldots \ldots \ldots \ldots . \ldots . \ldots 5$

G.1 Summary of contaminant concentrations in WOCE fish samples collected

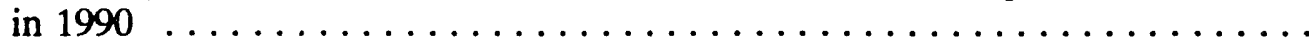

H.1 Results of conservative screening for carcinogens where at least one value was above detection limits

H.2 Results of conservative screening for noncarcinogens where at least one value was above detection limits

I.1 Results of nonconservative screening for carcinogens where at least one value was above detection limits

I.2 Results of nonconservative screening for noncarcinogens where at least one value was above detection limits

J.1 Int/ermittent intruder scenario screening indexes for detected cárcinogens $\ldots 119$

J.2 Intermittent intruder scenario screening indexes for detected noncarcinogens 
K.1 Results of conservative screening for carcinogens where no samples were above detection limits (Concentrations are the 95\% upper confidence bound of the arithmetic mean of the detection limits)

K.2 Results of conservative screening for noncarcinogens where no samples were above detection limits (Concentrations are the $95 \%$ upper confidence bound of the arithmetic mean of the detection limits) $\ldots \ldots \ldots \ldots \ldots \ldots$

L.1 Results of nonconservative screening for carcinogens where no samples were above detection limits (Concentrations are minimum detection limits) . 129

L.2 Results of nonconservative screening for noncarcinogens where no samples were above detection limits (Concentrations are minimum detection limits) . . 131

M.1 Comparison of TCLP values for WOCE sediments with regulatory guidelines

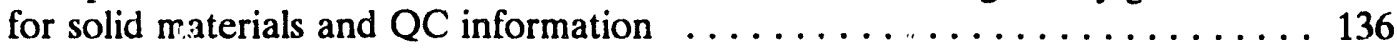




\section{ACKNOWLEDGEMENTS}

The authors wish to thank Dawn Miller and Scott Niemela of Automated Sciences Group, Inc., Tom Stephens of the Environmental Sciences Division, and George Houser of the Environmental and Health Protection Division for the effort they put forth in collecting and processing the multitude of samples essential to this study. Special thanks are due Lauren Larsen and Daniel Marsh of the Environmental Sciences Division for their cooperation in analyzing the samples for gamma emitters and maintaining a bigh level of quality control.

The conscientious data management efforts of Merilyn Gentry and Roy Longman of the University of Tennessee throughout the embayment study are truly appreciated. The authors wish to acknowledge the important contributions of Barbara Jackson of the Computing and Telecommunications Division to generating risk assessment and data summary tables and Craig Brandt of the Engineering Physics and Mathematics Division for his help in analyzing and interpreting the data representing the embayment sediment. The geographic information system expertise and efforts of Kris Dearstone of the Environmental Sciences Division in preparing maps and calculating areas of the embayment are greatly appreciated.

The perceptive reviews and constructive criticism offered by S. I. Auerbach, H. L. Boston, J. R. Trabalka, B. L. Kimmel, and R. B. Cook of the Environmental Sciences Division were extremely helpful in preparing the final report and our thanks go to them.

Last, but not least, we will to thank Becky Stanley of the Environmental Sciences Division whose exceptional secretarial skills greatly facilitated the production of this report. 


\section{EXECUTIVE SIJMMARY}

Analyses of sediment samples collected near the mouth of White Oak Creek during the summer of 1990 revealed ${ }^{137} \mathrm{Cs}$ concentrations $\left[>10^{6} \mathrm{~Bq} / \mathrm{kg}\right.$ dry wt $\left(>10^{4} \mathrm{pCi} / \mathrm{g}\right.$ dry wt)] near the sediment surface. Available evidence indicates that these relatively high concentrations of ${ }^{137} \mathrm{Cs}$ now at the sediment surface were released from White Oak Dam in the mid-1950s and had accumulated at depositional sites in the embayment. These accumulated sediments are being eroded and transported downstream primarily during winter low-water levels by flood events and by a combination of normal downstream flow and the water turbulence created by the release of water from Meiton Hill Dam during hydropower generation cycles. The U.S. Department of Energy and regulatory agencies were notified on September 7, 1990, of the contaminated surface sediments near the mouth of White Oak Creek. A time-critical Comprehensive Environmental Response, Compensation, and Liability Act removal action is being conducted, and a coffercell-type sediment-retention structure has been constructed at the mouth of White Oak Creek to reduce sediment erosion and to minimize the transport of radioactive sediments from the White Oak Creek Embayment (WOCE) into the Clinch River.

This report provides a more thorough characterization of the extent of contamination in WOCE than was previously available. Environmental samples collected from WOCE were analyzed for organic, inorganic, and radiological contaminants in fish, water, and sediment. These results were used to conduct a human health effects screening analysis. Walkover radiation surveys conducted inside the fenced area surrounding the WOCE at summer-pool (741 $\mathrm{ft}$ MSL) and at winter-pool ( $733 \mathrm{ft}$ MSL) level, indicated a maximum exposure rate of $3 \mathrm{mR} \mathrm{h}^{-1} 1 \mathrm{~m}$ above the soil surface.

Radiological data from sediment samples were used to estimate the inventory of radionuclides contained in the embayment sediment. Cesium-137 is the dominant radionuclide and the estimated inventory ranges from 6.6 to $11.8 \mathrm{Ci}$, depending on the method of calculation. The second highest inventory is for ${ }^{90} \mathrm{Sr}$, which has an estimated $0.2 \mathrm{Ci}$ in the sediment. Several other radionuclides are present but occur in much lower quantities.

A contaminant screening analysis was conducted to determine which contaminants in the embayment might be a problem from a human health standpoint. A screening analysis using nonconservative estimates for carcinogen exposure pathways for detectable contaminants identified arsenic in water ingestion, Aroclor-1254 (polychlorinated biphenyls) in fish ingestion, and ${ }^{60} \mathrm{Co}$ and ${ }^{137} \mathrm{Cs}$ in the sediment external exposure pathway as high priority contaminants requiring immediate consideration for remedial action. Arsenic in the water ingestion pathway is a possible artifact because only 2 of the 24 water samples analyzed had concentrations above the limits of detection. Two inorganic, three organic, and four radiological contaminants had screening indexes between $10^{-6}$ and $10^{-4}$. The screening analysis of noncarcinogens did not identify any detectable contaminants that should be assigned a high priority for consideration.

A screening analysis scenario was developed to permit a reasonable estimate of a maximum exposure to a hypothetical individual (an illegal intruder) under current conditions. Under this 
scenario, an individual using the embayment frequently for fishing purposes would be exposed to $>10^{-4}$ risk of excess cancer incidence from external exposure to ${ }^{137} \mathrm{Cs}$ in sediment and from ingestion of polychlorinated biphenyls in fish. All noncarcinogens had screening indexes of $<1.0$, indicating that concentrations of noncarcinogens were below the levels of concern for a realistic maximum exposure situation.

When completed, the sediment-retention, structure at the mouth of the embayment should reduce the transport of contaminated sediment into the Clinch River, maintain year-round inundation of the embayment sediments to reduce external radiation exposure, and impede the movement of fish into and out of the embayment. 


\section{SITE CHARACTERIZATION}

\subsection{INTRODUCTION}

The purpose of this report is to describe the rationale and background information that have led to the proposed construction of a sediment retention structure at the mouth of White Oak Creek to prevent the erosion and transport of radioactive sediments from White Oak Creek Embayment (WOCE). This report presents the sequence of events that led to this proposed action, a general description of the area and tharacterization of the contaminants, and a contaminant screening assessment for the embayment.

\subsubsection{Events Leading to the Interim Corrective Action}

A preliminary screening analysis of the Clinch River-Watts Bar Reservoir environment by Hoffman et al. (1990) identified WOCE as an area of concern to human health because of the potential for external exposure to ${ }^{137} \mathrm{Cs}$. The conclusion from this analysis is supported by a 1986 aerial survey that showed that the dose rate in the lower portion of WOCE from ${ }^{137} \mathrm{Cs}$ ranged from 42 to $64 \mu \mathrm{R} / \mathrm{h}$ (Fritzsche 1987) or about 227 to $345 \mathrm{mrem}$ per year. This dose rate exceeds radiation protection standards for members of the public. Background radiation in this vicinity is about 7 to $12 \mu R / \mathrm{h}$.

In accordance with the Clinch River remedial investigation (RI) Phase-I sampling plan Energy Systems 1990), a sediment core (9500G) was collected in late June 1990 from the 'ower portion of WOCE $50 \mathrm{~m}$ upstream from the mouth of White Oak Creek. This core was analyzed for gamma-emitting radionuclides and the data became available in August 1990. The core contained $\sim 1.7 \times 10^{6} \mathrm{~Bq} / \mathrm{kg}$ dry wt $\left(4.6 \times 10^{4} \mathrm{pCi} / \mathrm{g}\right.$ dry wt $)$ of ${ }^{137} \mathrm{Cs}$ in the surface sediment. The profile of ${ }^{137} \mathrm{Cs}$ concentration with depth for this core is shown in Fig. 1.1. The level of radioactivity was higher than had been anticipated and the sample was reanalyzed to verify its accuracy. Subsequently, 31 grab samples of surface sediment were collected on August 30, 1990, and analyzed for radioactivity to determine the spatial distribution of radionuclides in surface sediments in lower $V:-E$. Results of these analyses confirmed that relatively high levels of ${ }^{137} \mathrm{Cs}$ activity ranging fro... $<1.5 \times 10^{2}$ to about $7.9 \times 10^{5} \mathrm{~Bq} / \mathrm{kg}$ dry wt $\left(4.0 \times 10^{0}\right.$ to $2.1 \times 10^{4} \mathrm{pCi} / \mathrm{g}$ dry wt $)$ and averaging about $4.0 \times 10^{5} \mathrm{~Bq} / \mathrm{kg}$ dry wt $\left(1 \times 10^{4}\right.$ $\mathrm{pCi} / \mathrm{g}$ dry wt) existed in the surface sediments at the lower end of the embayment. Using a risk factor provided by the Environmental Protection Agency (EPA) (EPA 1990), a lifetime (70-year) exposure to surface sediment containing $11 \mathrm{~Bq} / \mathrm{kg}$ dry wt of ${ }^{137} \mathrm{Cs}$ would result in a $10^{-4}$ risk to an individual of developing excess cancer. A risk of $10^{-4}$ is considered an action level by EPA at Superfund sites.

In conjunction with the site characterization and risk-screening activities, an alternatives evaluation was conducted which identified a coffercell-type sediment-retention structure as an effective and environmentally appropriate method for achieving control of the contaminated sediments (U.S. Army Corps of Engineers 1991, Energy Systems 1991). 


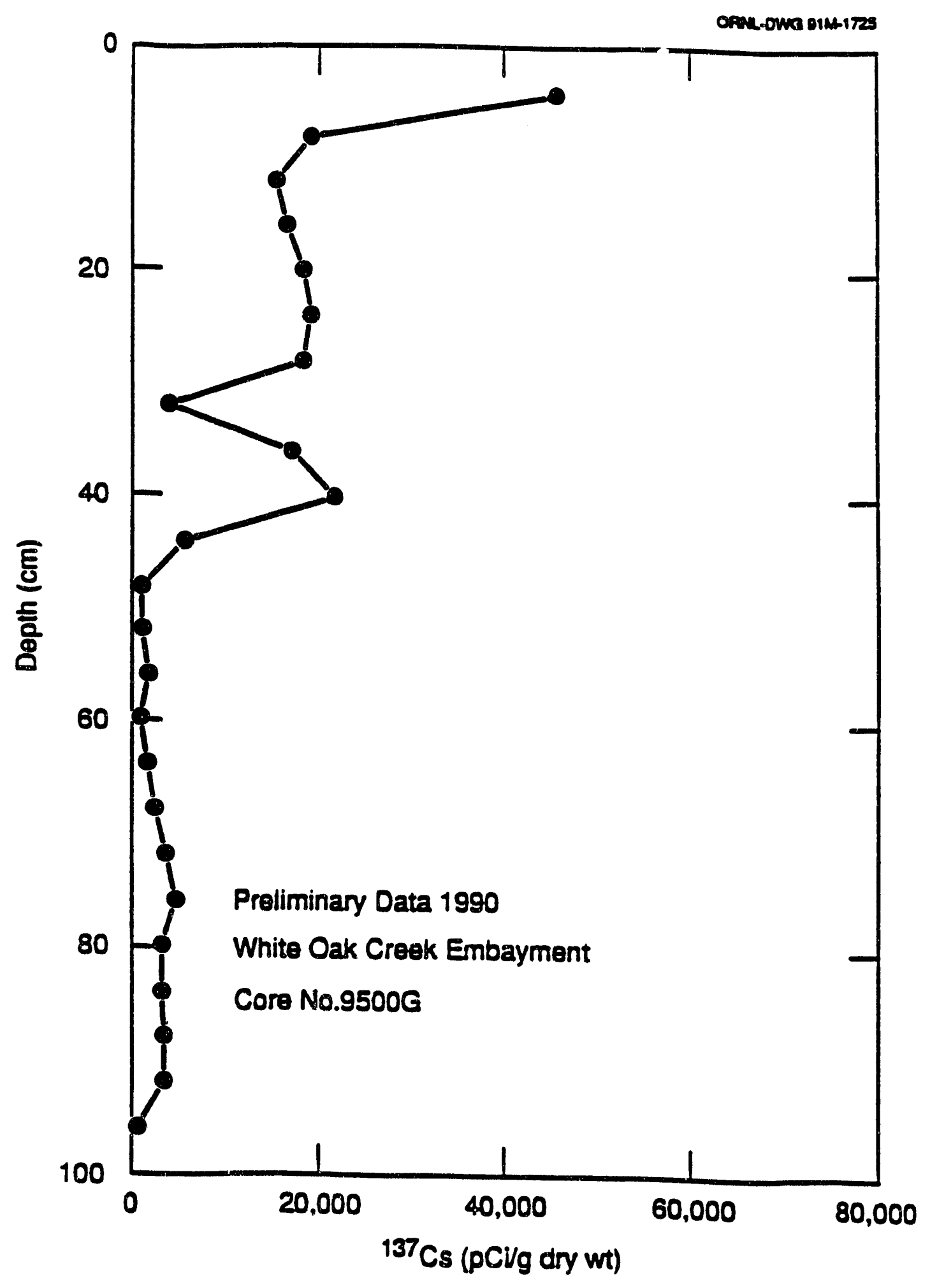

Fig. 1.1. Profile of ${ }^{137} \mathrm{Cs}$ concentrations of sediment in core no. $9500 \mathrm{G}$ taken $-50 \mathrm{~m}$ upstream from the mouth of White Oak Creek (1 pCi $=0.037 \mathrm{~Bq})$. 
The concentrations of ${ }^{137} \mathrm{Cs}$ found at the sediment surface produced immediate concern because surface sediments in the WOCE were not controlled (i.e., they could be readily eroded from the embayment and transported downstream into the Clinch River). On September 7, 1990, an occurrence report was filed and regulatory agencies were subsequently notified of the occurrence of contaminated surface sediments near the mouti: of White Oak Creek.

\subsection{DESCRIPTION OF THE AREA}

\subsection{White Oak Creek Watershed}

The White Oak Creek watershed drainage area is $\sim 16.8 \mathrm{~km}^{2}$ (6.5 square miles) (Fig. 1.2). White Oak Creek originates on the forested slope of Chestnut Ridge and flows $\sim 2.5 \mathrm{~km}$ (1.6 miles) in a southerly direction before entering the confines of the Oak Ridge National Laboratory (ORNL). Above ORNL, White Oak Creek ranges from 0.6 to $1.2 \mathrm{~m}$ (2.0 to $4.0 \mathrm{ft}$ ) in width and 10 to $25 \mathrm{~cm}$ ( 4 to $10 \mathrm{in}$ ) in depth and is fed by numerous springs. After the creek enters the environs of ORNL, a substantial part of the flow consists of waste water from ORNL operations. Melton Branch, which has a drainage area of $-3.8 \mathrm{~km}^{2}$ (1.5 square miles), enters White Oak Creek at km 2.5 (mile 1.56). White Oak Dam, a small earthen dam constructed in 1943, is located on White Oak Creek $1 \mathrm{~km}(0.6$ miles) upstream from the Clinch River. The portion of White Oak Creek below the dam to its mouth at Clinch River $\mathrm{km} 33.5$ (mile 20.8) is known as the WOCE.

The topography of the watershed consists of parallel, northeast-southwest trending valleys and ridges formed by differential erosion of alternating weak and resistant rock strata (Edgar 1978). Four major rock formations occurring in White Oak Creek Basin (McMaster and Waller 1965) are:

- Rome formation, underlying Haw Ridge, made up of shale, siltstone, and sandstone;

- Conasauga group, underlying Melton Valley, made up of shale, siltstone, and limestone;

- Knox dolomite, underlying Chestnut Ridge and Melton Hill; and

- Chickamauga limestone, underlying Bethel Valley.

Because the Rome formation and Conasauga group underlie most of the White Oak Creek Basin, the base-flow discharge of White Oak Creek is low, and during intervals of low rainfall, no natural flow occurs. The belt of Knox dolomite underlying Chestnut Ridge forms the northwestern drainage divide and is the principal water-bearing formation.

The soils of the basin are of the red-yellow podsolic, the reddish brown laterite, and the lithosol groups. These soils are strongly leached, low in organic matter, and acidic, and they generally have exchange capacities of less than $10 \mathrm{meq} / 100 \mathrm{~g}$ of soil. Texture varies from silty loam to plastic clay with infiltration capacities ranging from $15 \mathrm{~cm} / \mathrm{h}(10 \mathrm{in} . / \mathrm{h})$ to less than $0.5 \mathrm{~cm} / \mathrm{h}(0.2 \mathrm{in} . / \mathrm{h})$ (McMaster and Waller 1965).

\subsection{White Oak Lake Dam}

In 1941, the Tennessee Valley Authority (TVA) placed a culvert and an earthen fill at White Oak Creek km 1.0 (mile 0.6) for a highway crossing. In 1943, interlocking steel piling 


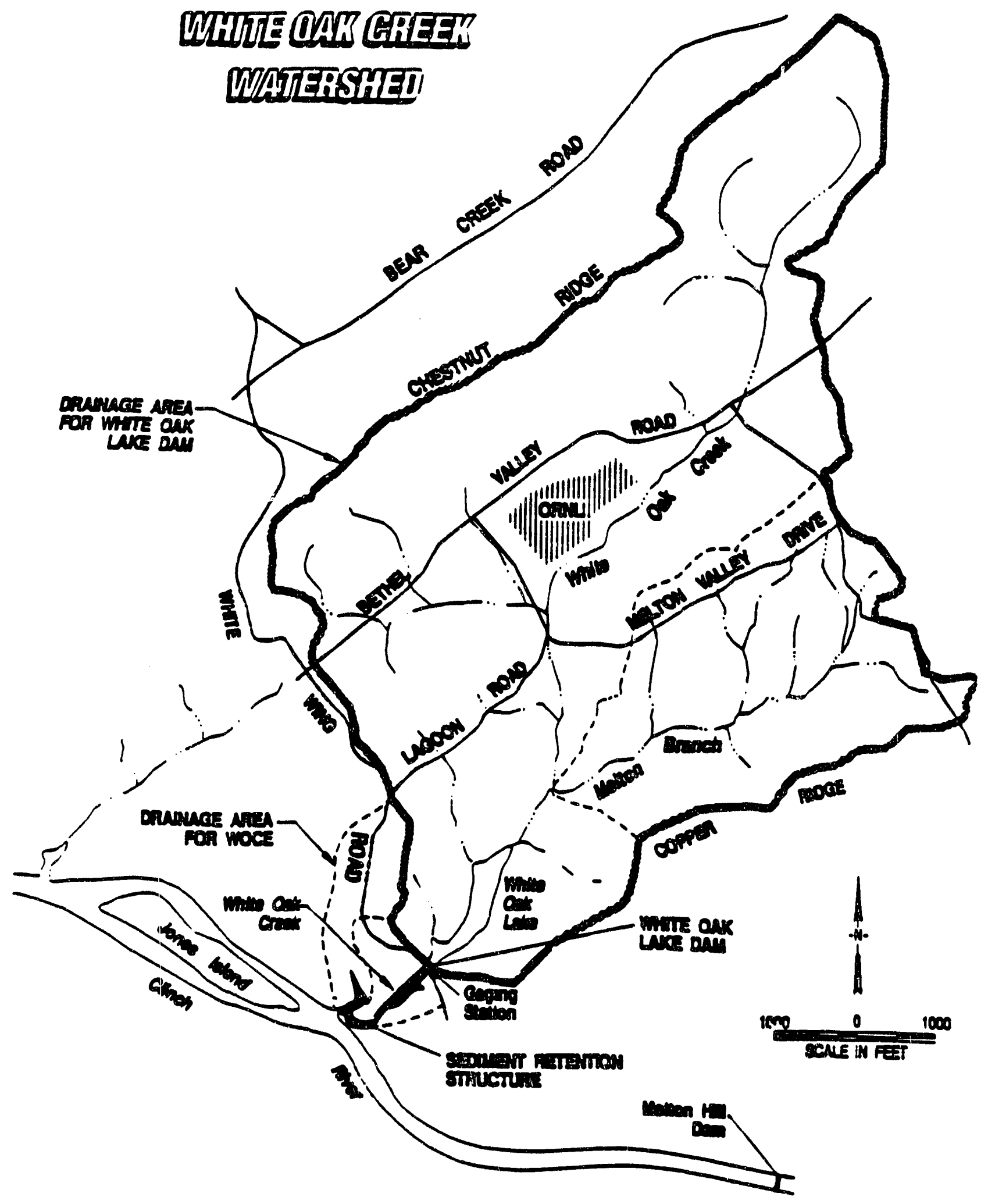

Fig. 1.2 The White Oak Creek Watershed, including the Oak Ridge National Laboratory and associated waste disposal areas. Drainage area is outlined by the broad dark lines. 
and a sluice gate were placed on the upstream side of the culvert creating White Oak Lake. At the overflow elevation of $228.5 \mathrm{~m}$ (750 ft ) MSL the impoundment was $-3.15 \times 10^{5} \mathrm{~m}^{3}$ $\left(10.5 \times 10^{6} \mathrm{ft}^{3}\right)$ with a surface area of 17.9 ha $(44.2$ acres $)$. The gate on the spillway was raised or lowered to increase the water retention time of White Oak Lake and permit the settling of suspended solids and the decay of short-lived radionuclides. Until 1949, the normal operating level of the dam ranged from 227.5 to $228.2 \mathrm{~m}$ ( 747 to $749 \mathrm{ft}$ ) $\mathrm{MSL}$, which resulted in an impoundment of 12 to 16 ha (30 to 40 acres). At a flow rate of $7.5 \mathrm{cfs}$, the storage capacity was $23.1 \mathrm{~d}$ at an elevation of $228.5 \mathrm{~m}$ (750 ft ) MSL (Setter and Kochtitzky 1950); however, periodic heavy rains could flush out the lake in a few hours.

In 1979, White Oak Lake was drawn down when an evaluation of the integrity of White Oak Dam indicated the possibility of internal erosion that could lead to subsidence (Oakes et al. 1982a, Tschantz 1987). Plans were made for improving the structure of the dam and providing a new discharge structure on the northwest side that would accommodate a 100 -year flood (Oakes et al. 1982a, Boyle et al. 1982). In 1980, the dam was stabilized by adding a rock berm over a crushed rock and sand fill on the downstream side of the dam. The new discharge channel and weir system were completed in 1983.

\subsection{White Oak Lake}

White Oak Lake has served as the final settling basin for low-level radioactive effluents from ORNL since 1943. Low levels of radioactivity are released over the dam and are either deposited in the embayment sediments or transported to the Clinch River. Current levels of radioactivity that are released over the dam are much lower than in early years (Table 1.1), usually less than one $\mathrm{Ci}$ per year of ${ }^{137} \mathrm{Cs}$. However, in the past, larger quantities were released. For example, after the lake was drained in $1955, \sim 170 \mathrm{Ci}$ of ${ }^{137} \mathrm{Cs}$ (DOE 1988) were re' aased over White Oak Dam in 1956.

In 1954, it was determined that White Oak Lake was no longer effective in terms of its ability to dilute and otherwise retain radioactive materials (Lee and Auerbach 1959). The fish population was poisoned with rotenone and removed and the lake was partially drained in October 1955 , leaving a standing pond of $\sim 2.8$ ha (6.1 acres) behind the dam. The lake was drained slowly so that the contaminated silt would not be disturbed. Measurements of the radiation field above the lake bed showed that the highest dose rates were associated with former stream channels that had been filled with contaminated silt (Lee and Auerbach 1959). Flooding in 1956 and later years eroded the stream channels down to their preimpoundment depth. In 1961, an investigation was conducted to determine the extent of sediment deposition or losses from the lake bed since the draining in 1955 (Oakes et al. 1982a). By comparing measurements of the depth of sediments in 1961 with measurements made by TVA in 1953, investigators reached an estimate that $-4250 \mathrm{~m}^{3}\left(150,000 \mathrm{ft}^{3}\right)$ of silt left the lake bed because of siream channel and lake bed erosion.

From 1955 to 1969 , the size of White Oak Lake varied with changes in gate elevation that gradually increased the size of the lake. In 1960, the lake area was increased to 3.2 ha (8 acres). In 1963 in response to th: construction of Melton Hill Dam on the Clinch River at $37.4 \mathrm{~km}$ (CRM 23.4), the gate was reworked and the size of the lake was increased to 6.0 ha (15.0 acres). By 1969, the surface area of the lake was 10.5 ha (26.3 acres) (Kolehmainen and Nelson 1969), and it remained approximately this size until late November of 1979 when the elevation was reduced to $226 \mathrm{~m}$ ( $742 \mathrm{ft}$ ) MSL to permit improvements to 
Table 1.1. Estimated discharges of selected radionuclides from White Oak Creek to the Clinch River (curies)

\begin{tabular}{|c|c|c|c|c|c|c|c|}
\hline Year & ${ }^{137} \mathrm{Cs}$ & ${ }^{106} \mathrm{Ru}$ & ${ }^{90} \mathrm{Sr}$ & ${ }^{131} 1$ & ${ }^{60} \mathrm{Co}$ & ${ }^{3} \mathrm{H}$ & $\operatorname{TRU}^{b}$ \\
\hline 1949 & 77 & 110 & 150 & 77 & & $N^{c}{ }^{c}$ & $0.04^{d}$ \\
\hline 1950 & 19 & 23 & 38 & 19 & & & 0.04 \\
\hline 1951 & 20 & 18 & 29 & 18 & & & 0.08 \\
\hline 1952 & 10 & 15 & 72 & 20 & & & 0.03 \\
\hline 1953 & 6 & 26 & 130 & 2 & & & 0.08 \\
\hline 1954 & 22 & 11 & 140 & 4 & NA & & 0.07 \\
\hline 1955 & 63 & 31 & 93 & 7 & 7 & & 0.25 \\
\hline 1956 & 70 & 29 & 100 & 4 & 46 & & 0.28 \\
\hline 1957 & 89 & 60 & 83 & 1 & 5 & & 0.15 \\
\hline 1958 & 55 & 42 & 150 & 8 & 9 & & 0.08 \\
\hline 1959 & 76 & 520 & 60 & 1 & 77 & & 0.68 \\
\hline 1960 & 31 & 1900 & 28 & 5 & 72 & & 0.19 \\
\hline 1961 & 15 & 2000 & 22 & 4 & 31 & & 0.07 \\
\hline 1962 & 6 & 1400 & 9 & 0.4 & 14 & & 0.06 \\
\hline 1963 & 4 & 430 & 8 & 0.4 & 14 & & 0.17 \\
\hline 1964 & 6 & 190 & 7 & 0.3 & 15 & 1,900 & 0.08 \\
\hline 1965 & 2 & 69 & 3 & 0.2 & 12 & 1,200 & 0.50 \\
\hline 1966 & 2 & 29 & 3 & 0.2 & 7 & 3,100 & 0.16 \\
\hline 1967 & 3 & 7 & 5 & 0.9 & 3 & 13,300 & 1.03 \\
\hline 1968 & 1 & 5 & 3 & 0.3 & 1 & 9,700 & 0.04 \\
\hline 1969 & 1 & 2 & 3 & 0.5 & 1 & 12,200 & 0.20 \\
\hline 1970 & 2 & 1 & 4 & 0.3 & 1 & 9,500 & 0.40 \\
\hline 1971 & 1 & 0.5 & 3 & 0.2 & 1 & 8,900 & 0.05 \\
\hline 1972 & 2 & 0.5 & 6 & 0.3 & 1 & 10,600 & 0.07 \\
\hline 1973 & 2 & 0.7 & 7 & 0.5 & 1 & 15,000 & 0.08 \\
\hline 1974 & 1 & 0.2 & 6 & 0.2 & 0.6 & 8,600 & 0.02 \\
\hline 1975 & 0.6 & 0.3 & 7 & 0.3 & 0.5 & 11,000 & 0.02 \\
\hline 1976 & 0.2 & 0.2 & 5 & 0.03 & 0.9 & 7,400 & 0.01 \\
\hline 1977 & 0.2 & 0.2 & 3 & 0.03 & 0.4 & 6,200 & 0.03 \\
\hline 1978 & 0.3 & 0.2 & 2 & 0.04 & 0.4 & 6,300 & 0.03 \\
\hline 1979 & 0.2 & 0.1 & 2.4 & 0.04 & 0.4 & 7,700 & 0.03 \\
\hline 1980 & 0.6 & 0 & 1.5 & 0.04 & 0.4 & 4,600 & 0.04 \\
\hline 1981 & 0.2 & 0.1 & 1.5 & 0.04 & 0.7 & 2,900 & 0.04 \\
\hline 1982 & 1.5 & 0.2 & 2.7 & 0.06 & 1.0 & 5,400 & 0.03 \\
\hline 1983 & 1.2 & 0.2 & 2.1 & 0.004 & 0.3 & 5,600 & 0.05 \\
\hline 1984 & 0.6 & 0.2 & 2.6 & 0.05 & 0.2 & 6,400 & 0.03 \\
\hline 1985 & 0.4 & 0.007 & 3.0 & & 0.6 & 3,700 & 0.008 \\
\hline 1986 & 1.0 & 0 & 1.8 & & 0.54 & 2,600 & 0.024 \\
\hline 1987 & 0.6 & 0 & 1.2 & & 0.12 & 2,500 & 0.006 \\
\hline 1988 & 0.4 & 0 & 1.1 & & $<0.07$ & 1,700 & \\
\hline 1989 & 1.2 & 0 & 2.9 & & 0.13 & 4,100 & \\
\hline 1990 & 1.1 & 0 & 3.1 & & 0.12 & 3,100 & \\
\hline Total & 696.3 & $6,931.6$ & $1,204.9$ & 175.33 & 325.26 & 175,200 & 5.248 \\
\hline
\end{tabular}

${ }^{a}$ All digits carried through to avoid rounding errors. Only first two are significant.

$b$ Transuranics.

c "NA" means no analysis performed.

${ }^{d}$ Estimated from measurements made during last quarter of 1949. 
the structure of the dam and construction of the new weir. A standing pond of $\sim 5.2$ ha (13 acres) (Loar et al. 1981) existed during this time. The lake is currently maintained at an elevation of $227 \mathrm{~m}$ ( $745 \mathrm{ft}$ ) MSL with a standing pond of $\sim 6.9$ ha (17 acres). Historical changes in the surface area of the lake and the major events associated with significant changes in the lake are summarized in Table 1.2.

\subsubsection{Inventory of Radionuclides in White Oak Lake Sediments}

Radioactive contamination of the sediment in White Oak Lake is well documented (Lomenick and Gardiner 1965, Oakes et al. 1982a, and Sherwood and Loar 1987). Estimates of the inventory of radionuclides in the sediment for different years are given in Table 1.3. Lomenick and Gardiner's (1965) estimate was based on the results of a comprehensive 250 -core sampling program and is probably the most reliable estimate. The most recent estimate of the radionuclides in the sediment was made by Blaylock and Mohrbacher [Loar (ed) 1989].

\subsubsection{White Oak Creek Embayment}

WOCE is the hydrologic link between White Oak Lake Dam and the Clinch River. WOCE extends $1 \mathrm{~km}$ ( 0.6 mile) downstream from White Oak Dam and joins the Clinch River, an arm of Watts Bar Reservoir, at km 33.5 (mile 20.8) (Fig. 1.2). Water level and flow in WOCE are largely controlled by the operation of Melton Hill Dam and Watts Bar Dam. Melton Hill Dam is $4.7 \mathrm{~km}$ (2.6 miles) upstream of the mouth of White Oak Creek on the Clinch River. Watts Bar Dam, which forms Watts Bar Reservoir, is about 90 km (56.4 miles) downstream on the Tennessee River. The summer water elevation at the mouth of White Oak Creek at Watts Bar Reservoir is $225.8 \mathrm{~m}$ (741 ft ) MSL. At this elevation, the depth of water at the upper end of the embayment ranges from 0.3 to $1.0 \mathrm{~m}$ ( 1 to $3 \mathrm{ft}$ ) and the width is $-68.5 \mathrm{~m}(225 \mathrm{ft})$. At the lower end the embayment narrc ws to a width of $\sim 12 \mathrm{~m}(40 \mathrm{ft})$ and the maximum depth is $\sim 3 \mathrm{~m}(10 \mathrm{ft})$. The width at the mouth of WOCE is $-36.5 \mathrm{~m}(120 \mathrm{ft})$. The area of the embayment at the summer pool level is $-33,570 \mathrm{~m}^{2}$ ( 8.5 acres). The winter elevation at the mouth of WOCE is $223 \mathrm{~m}(733 \mathrm{ft})$ MSL. At winter pool, White Oak Creek is a small stream that meanders through mud flats that are covered by water at the summer pool elevation. At the lower end of the stream, as it approaches the Clinch River, the water can reach a depth of 1 to $2 \mathrm{~m} \mathrm{(3} \mathrm{to} 6 \mathrm{ft}$ ) in winter. During winter, the lower mud flats are covered periodically $b_{y}$, water because of high precipitation or the operation of Melton Hill Dam.

\subsubsection{Melton Hill Dam}

Melton Hill Dam, located at km 37.7 (mile 23.4) on the Clinch River, is a TVA hydroelectric dam that was completed in 1963 (Fig 1.2). The electrical generating capacity of the dam is used as a peaking unit in TVA's power production grid, usually generating electricity twice a day. When the generators are operating, the release of water from the dam reverses the flow in WOCE and increases the depth of water at the mouth of the embayment by more than $2 \mathrm{ft}$ within a few minutes (Fig. 1.3). When the generators stop operating, the current in WOCE reverses direction and the excess water is rapidly discharged into the Clinch River. This phenomenon increases the potential for sediment erosion in the lower portion of the embayment and sediment transport from the embayment to the Clinch River. 


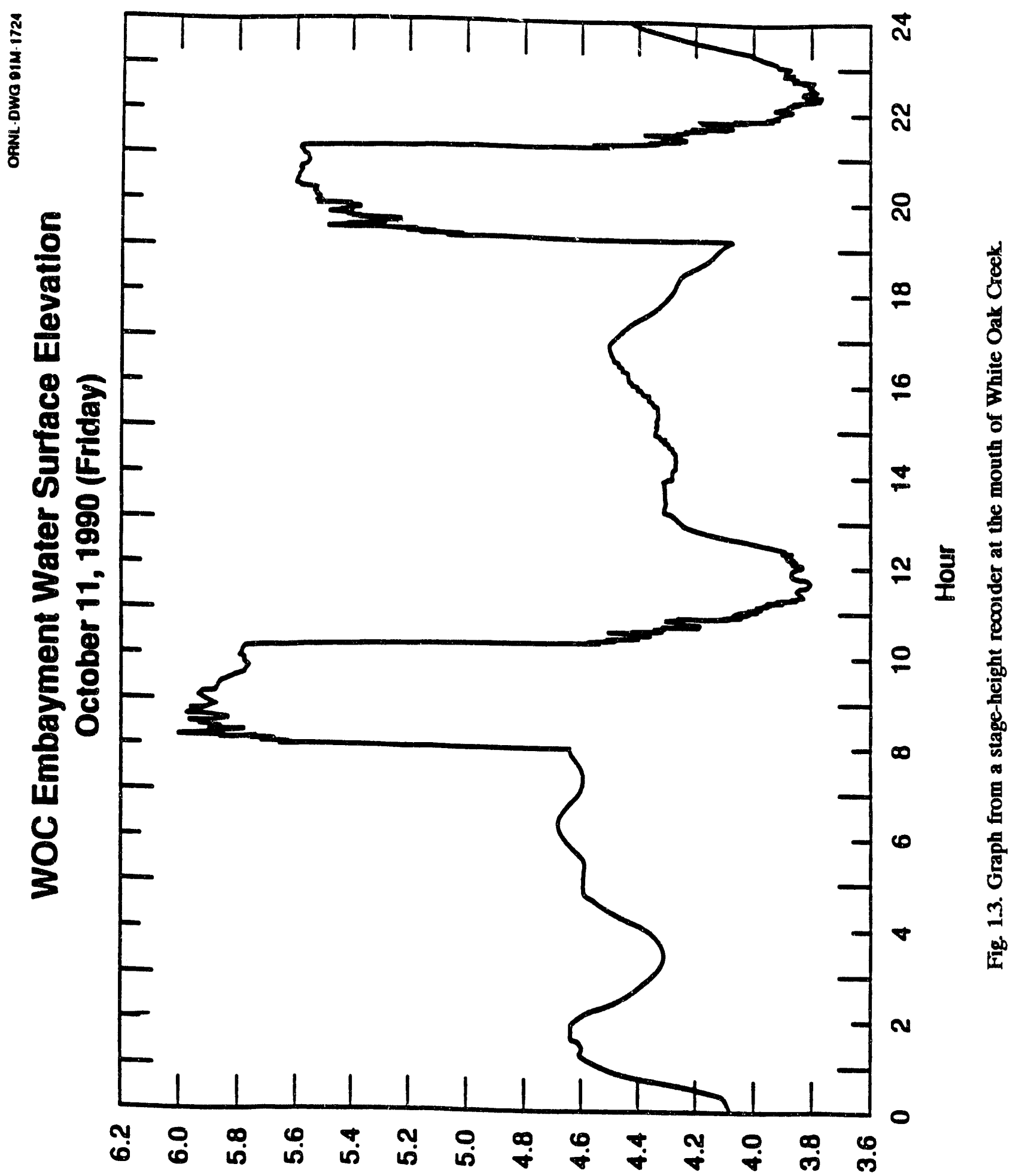

(4) Obeis 
Table 1.2. Historical changes in White Oak Lake

\begin{tabular}{|c|c|c|c|}
\hline Date & $\begin{array}{l}\text { Surface } \\
\text { area (ha) }\end{array}$ & Events & References \\
\hline 1941 & & Highway fill and culvert installed by TVA & Smith 1945 as in Krumholz 1954 \\
\hline 1943 & 14.5 & $\begin{array}{l}\text { Sheet piling dam installed with spillway with } \\
\text { vertical sliding gate }\end{array}$ & Krumholz 1954 \\
\hline 1943 & & $\begin{array}{l}\text { Generation of radioactive waste at ORNL began } \\
\text { and lake served as final settling basin ( } 150 \mathrm{ft} \\
\text { MSL) }\end{array}$ & Morton 1961 \\
\hline 1944 & NA & $\begin{array}{l}\text { Dikes at White Oak Creek km } 3.3 \text { and } 3.9 \\
\text { washed out ( } 7.75 \text { in., } 26 \text { h, } 3.5 \text { in. runoff) }\end{array}$ & Setter and Kochtitzky 1950 \\
\hline 1945 & 12.2 & $\begin{array}{l}\text { Investigation of structural strength of dam } \\
(746.5 \mathrm{ft})\end{array}$ & Oakes et al. 1982a \\
\hline 1948 & 10.3 & $\begin{array}{l}\text { Lake lowered to } 745.5 \mathrm{ft} \text { to facilitate sediment } \\
\text { sampling, normal operation from } 1948 \text { to } 1955 \\
\text { was from } 747 \text { to } 749 \mathrm{ft}\end{array}$ & Oakes et al. 1982a \\
\hline 1953 & NA & $\begin{array}{l}\text { Lake partially drained during rotenone survey of } \\
\text { fish population }\end{array}$ & Oakes et al. 1982a \\
\hline 1955 & 2.8 & $\begin{array}{l}\text { Lake drained: radionuclides in lake sediment and } \\
\text { water believed to be in equilibrium so lake } \\
\text { served no useful function in retaining } \\
\text { radioactivity but could function as an emergency } \\
\text { storage basin }\end{array}$ & Morton 1961 \\
\hline 1956 & 0.4 & $\begin{array}{l}\text { Significant releases of }{ }^{137} \mathrm{Cs} \text { probably from } \\
\text { erosion of freshly exposed sediment after lake } \\
\text { was drained }\end{array}$ & Lackey 1957 \\
\hline 1959 & NA & $\begin{array}{l}\text { Gate structure renovated to prevent inflow of } \\
\text { backwaters from Clinch River }\end{array}$ & Morton 1961 \\
\hline 1960 & 3.2 & Dam closed, surface level raised & Kolehmainen and Nelson 1969 \\
\hline 1963 & 6.0 & Completion of Melton Hill Dam & Kolehmainen and Nelson 1969 \\
\hline 1967 & 8.1 & None reported & McMaster 1967 \\
\hline 1969 & 10.5 & None reported & Kolehmainen and Nelson 1969 \\
\hline 1979 & 4.6 & $\begin{array}{l}\text { Lake level gradually dropped from } 745 \text { to } 742 \mathrm{ft} \\
\text { because of potential instability of the dam }\end{array}$ & Oakes et al. $1982 a$ \\
\hline 1980 & 6.9 & $\begin{array}{l}\text { Construction of a berm to stabilize dam was } \\
\text { completed }\end{array}$ & Boyle et al. 1982 \\
\hline 1983 & 6.9 & $\begin{array}{l}\text { Discharge channel and weir constructed, roadbed } \\
\text { rerouted }\end{array}$ & Oakes et al. $1982 \mathrm{~b}$ \\
\hline 1988 & 6.9 & $\begin{array}{l}\text { Estimate of surface area and volume }\left(43,900 \mathrm{~m}^{3}\right) \\
\text { at lake elevation of } 74.5 \mathrm{ft}\end{array}$ & Cox et al. 1991 \\
\hline
\end{tabular}


Tak'. . .3. Budget of radionuclides (curies) in White Oak Lake sadiment

\begin{tabular}{|c|c|c|c|c|c|c|c|}
\hline Date & ${ }^{60} \mathrm{Co}$ & ${ }^{137} \mathrm{Cs}$ & "Ru & ${ }^{90} \mathrm{Sr}$ & $\mathrm{TRE}^{a}$ & Total & Reference \\
\hline 1945 & & & & & & 21 & \\
\hline 1946 & & & & & & 20 & \\
\hline 1948 & & & & & & 310 & \\
\hline 1950 & & & & & & 392 & Ahee 1953 \\
\hline 1951 & & & & & & 359 & \\
\hline 1952 & & & & & & 303 & \\
\hline 1962 & 152 & 704 & 1038 & 14.6 & 16.6 & 1925 & $\begin{array}{l}\text { Lomenick and } \\
\text { Gardiner } 1965\end{array}$ \\
\hline 1979 & 33 & 591 & & 20 & & 644 & Oakes et al. 1982a \\
\hline 1989 & 11.4 & 405 & & 17.8 & & 434 & Loar (ed) 1989 \\
\hline
\end{tabular}

\subsection{CONTAMINANTS IN WHITE OAK CREEK EMBAYMENT}

\subsubsection{Radionuclides in White Oak Creek Embayment}

ORNL has hosted an array of nuclear and other research programs involving radioactive materials, such as reactor operations, fuel element reprocessing, reactor-related research, isotope production, and environmental research. Some of these activities have resulted in the release to White Oak Creek and Melton Branch of (1) primary fission products including ${ }^{90} \mathrm{Sr}$, ${ }^{137} \mathrm{Cs}$, and rare earth radionuclides and (2) activation products including ${ }^{60} \mathrm{Co}$ and many long-lived isotopes of transuranic elements such as plutonium. Radioactive contamination of the sediment of WOCE is well documented (Oakes et al. 1982a, TVA 1984). The dominant gamma-emitting radionuclide in WOCE is ${ }^{137} \mathrm{Cs}$.

\subsubsection{Historical Radiological Data}

Sediment cores and surface grab samples have been collected from WOCE previously and analyzed for radioactivity (Cerling and Spalding 1981, Oakes et al. 1982b, and TVA 1986). The gamma-emitting radionuclides with the highest concentrations in these sediment samples were ${ }^{137} \mathrm{Cs}$ and ${ }^{60} \mathrm{Co}$, with ${ }^{137} \mathrm{Cs}$ concentrations usually approximately an order of magnitude higher than those for ${ }^{60} \mathrm{Co}$. In 1978, twenty four sediment cores were collected from the embayment and analyzed for radionuclides by Oakes et al. (1982b). Core no. 23, taken from the lower portion of the embayment (Fig. 1.4) contained the highest concentration of ${ }^{137} \mathrm{Cs}$, $\sim 3.0 \times 10^{6} \mathrm{~Bq} / \mathrm{kg}$ dry wt $\left(8.0 \times 10^{4} \mathrm{pCi} / \mathrm{g}\right.$ dry wt $)$ at a depth of $66 \mathrm{~cm}(26 \mathrm{in}$.$) , that had been$ reported for WOCE prior to 1990 . Radionuclide concentrations measured in the sediment cores taken by Oakes et al. (1982b) are listed according to depth in Appendix A. Cesium-137 concentrations in surface grab samples taken by Cerling and Spalding (1981) in the upper portion of the embayment ranged from $3.6 \times 10^{4}$ to $2.0 \times 10^{5} \mathrm{~Bq} / \mathrm{kg}$ dry wt $\left(9.7 \times 10^{2}\right.$ to 5.4 $\times 10^{3} \mathrm{pCi} / \mathrm{g}$ dry wt) and averaged $\sim 1.5 \times 10^{5} \mathrm{~Bq} / \mathrm{kg}$ dry wt $\left(3.9 \times 10^{3} \mathrm{pCi} / \mathrm{g}\right.$ dry wt $)$. 


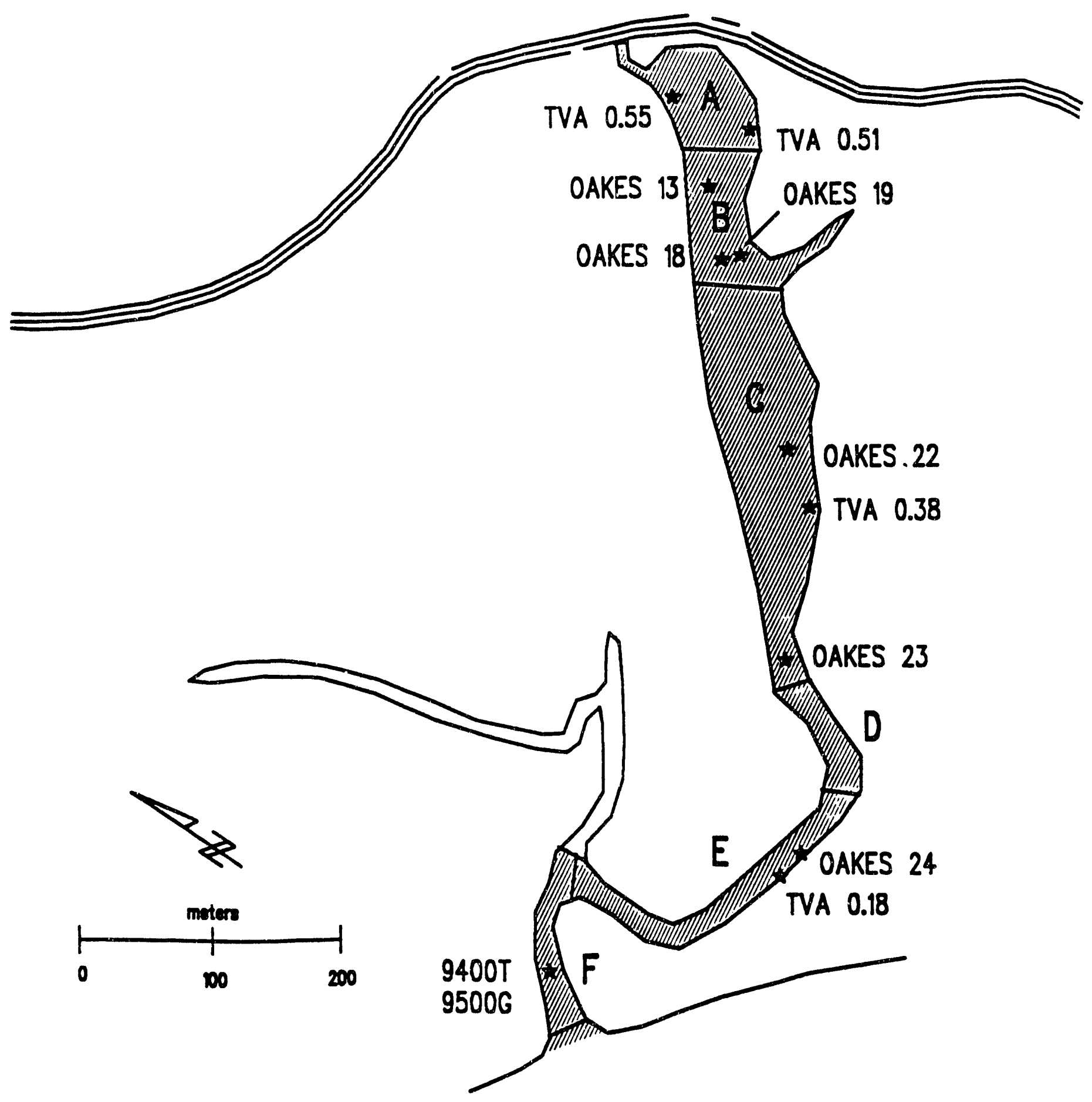

Fig. 1.4. Location of historical core sampling sites in WOCE and site of core $9500 \mathrm{G}$ (9500T is split of 9500G) which was collected in June 1990. The embayment was divided into six areas for the purpose of estimating inventories of radionuclides. 
In 1984, four sediment cores were collected by TVA (TVA 1986) and analyzed for radioactivity and other contaminants. The cores were divided into 3- to 5-in. depth intervals for analysis of radioactivity. A sediment core collected by TVA a short distance downstream from Oakes' core no. 24 (Fig. 1.4) contained $\sim 1.7 \times 10^{6} \mathrm{~Bq} / \mathrm{kg}$ dry wt $\left(4.7 \times 10^{4} \mathrm{pCi} / \mathrm{g}\right.$ dry wt) of ${ }^{137} \mathrm{Cs}$ at a depth of $\sim 25 \mathrm{~cm}$. In addition to the data from these core samples, a summary of the TVA core data is given in Table 1 of Appendix B.

\subsubsection{Recent Radiological Data}

Sediment core $9500 \mathrm{G}$, referred to previously, was taken in June 1990 as part of the Clinch River RI Phase I sampling and analyzed for radionuclides and inorganic contaminants (Energy Systems 1990). A summary of the data is given in Table 1 of Appendix C. The core was sectioned into 4-cm lengths to obtain a depth profile of the contaminant.s. Core $9500 \mathrm{G}$ was taken $-50 \mathrm{~m}$ upstream from the mouth of the embayment (Fig. 1.4). The surface sediments (0- to 4-cm depth) contained $-1.7 \times 10^{6} \mathrm{~Bq} / \mathrm{kg}$ dry wt $\left(4.6 \times 10^{4} \mathrm{pCi} / \mathrm{g}\right.$ dry wt $)$ of ${ }^{137} \mathrm{Cs}$. A comparison of the depth profile of the concentration of ${ }^{137} \mathrm{Cs}$ iil this core with previous cores collected by Oakes et al. (1982b) and TVA (1986) is shown in Fig. 1.5. The highest concentrations of ${ }^{137} \mathrm{Cs}$ detected in 1979 (Oakes et al. 1982b) and 1984 (TVA 1986) cores were 30 or more $\mathrm{cm}$ below the sediment surface; whereas, the core taken in June 1990 showed the highest concentration at the sediment surface. In addition, core $9500 \mathrm{G}$ was taken nearer the mouth of the creek and several hundred meters downstream from previous core sample sites.

After core $9500 \mathrm{G}$ was taken in June 1990, 31 additional sediment cores were taken in the embayment (Fig. 1.6) and analyzed for gamma-emitting radionuclides. Three transects were established across the embayment downstream from the location of core 9500G. Eight cores were taken along a transect at the mouth of the embayment. Eleven cores were taken along a transect at the mouth, and another seven along a transect $\sim 10 \mathrm{~m}$ upstream from the mouth. In addition, another sediment core $10800 \mathrm{G}$ was taken near the site of the $9500 \mathrm{G}$ core and others were taken farther upstream (Fig. 1.6) for analysis of gamma emitters. Details of the procedures used for collecting and processing the sediment samples are given in the Clinch River RI Plan (Energy Systems 1990).

Depth profiles of ${ }^{137} \mathrm{Cs}$ for cores from the three transects near the mouth of the embayment are shown in Figs. D1, D2, and D3. These profiles show that the distribution of ${ }^{137} \mathrm{Cs}$ is heterogeneous with depth and that the highesi concentrations are found near the middle of the channel in depositional zones. The maximum concentration of ${ }^{137} \mathrm{Cs}$ $\left(2.2 \times 10^{6} \mathrm{~Bq} / \mathrm{kg}\right)$ was detected at a depth of 22 to $24 \mathrm{~cm}$ in core $58400 \mathrm{G}$ which was taken midchannel about $10 \mathrm{~m}$ upstream from the mouth of the embayment (Fig. 1.6). The highest concentration of ${ }^{60} \mathrm{Co}\left(7.0 \times 10^{3} \mathrm{~Bq} / \mathrm{kg}\right)$ was found in core $54400 \mathrm{G}$ which was taken midchannel about $10 \mathrm{~m}$ upstream from the mouth of the embayment. Depth profiles of cores taken adjacent to each other show the heterogenous distribution of ${ }^{137} \mathrm{Cs}$ with space as well as depth (Fig. 4 of Appendix D). Higher concentrations of ${ }^{137} \mathrm{Cs}$ and ${ }^{60} \mathrm{Co}$ could be present in the embayment, but even more intensive sampling would be required to make this determination.

Core $9500 \mathrm{G}$ was divided into $4-\mathrm{cm}$ sections and each section was analyzed for ${ }^{241} \mathrm{Am}$, ${ }^{244} \mathrm{Cm},{ }^{239-240} \mathrm{Pu},{ }^{234} \mathrm{U},{ }^{235} \mathrm{U},{ }^{238} \mathrm{U}$, and ${ }^{90} \mathrm{Sr}$. A summary of the data for these radionuclides, including the maximum and mean concentrations, is provided in Table 3 of Appendix D. The 


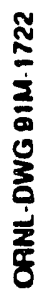

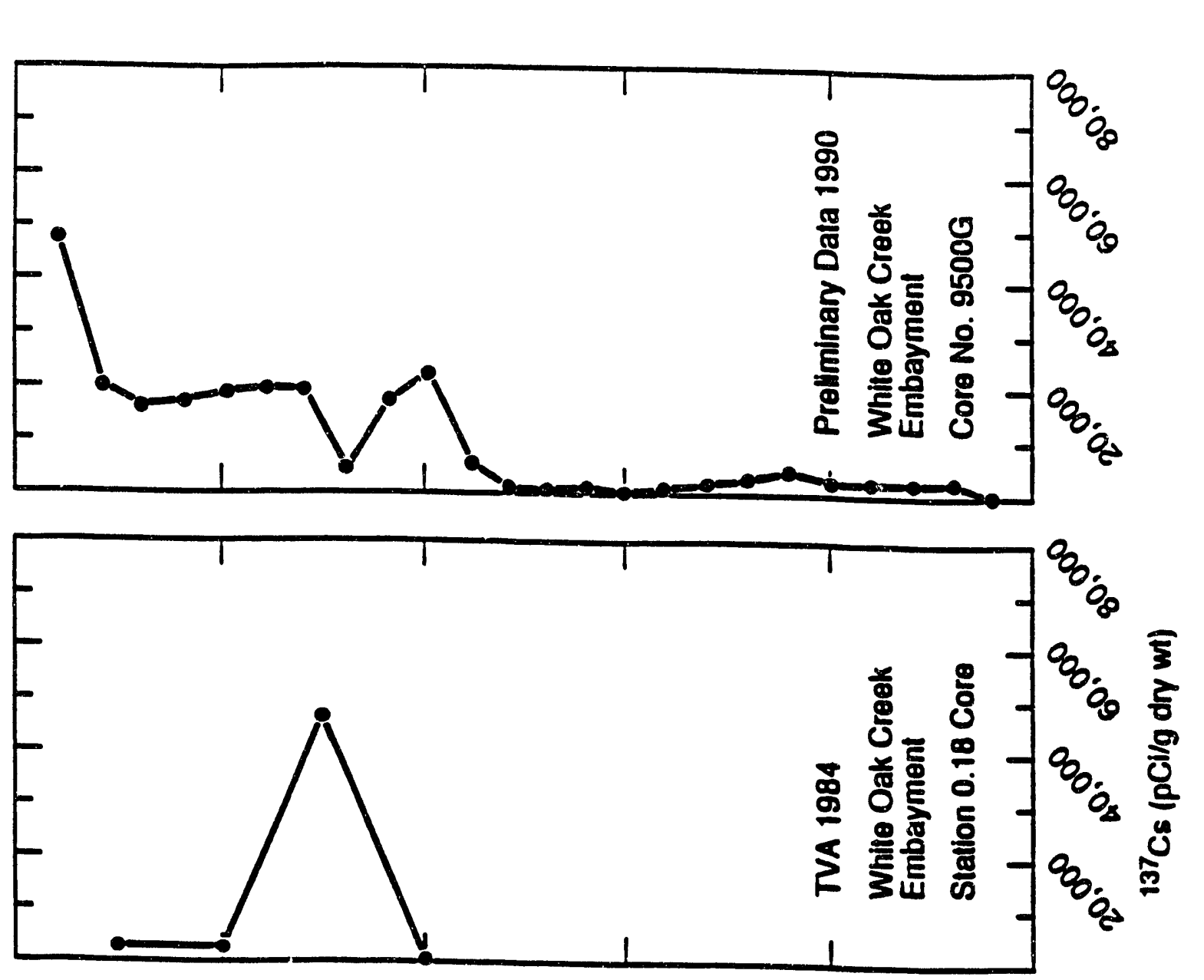

ริ

ช్

II

8

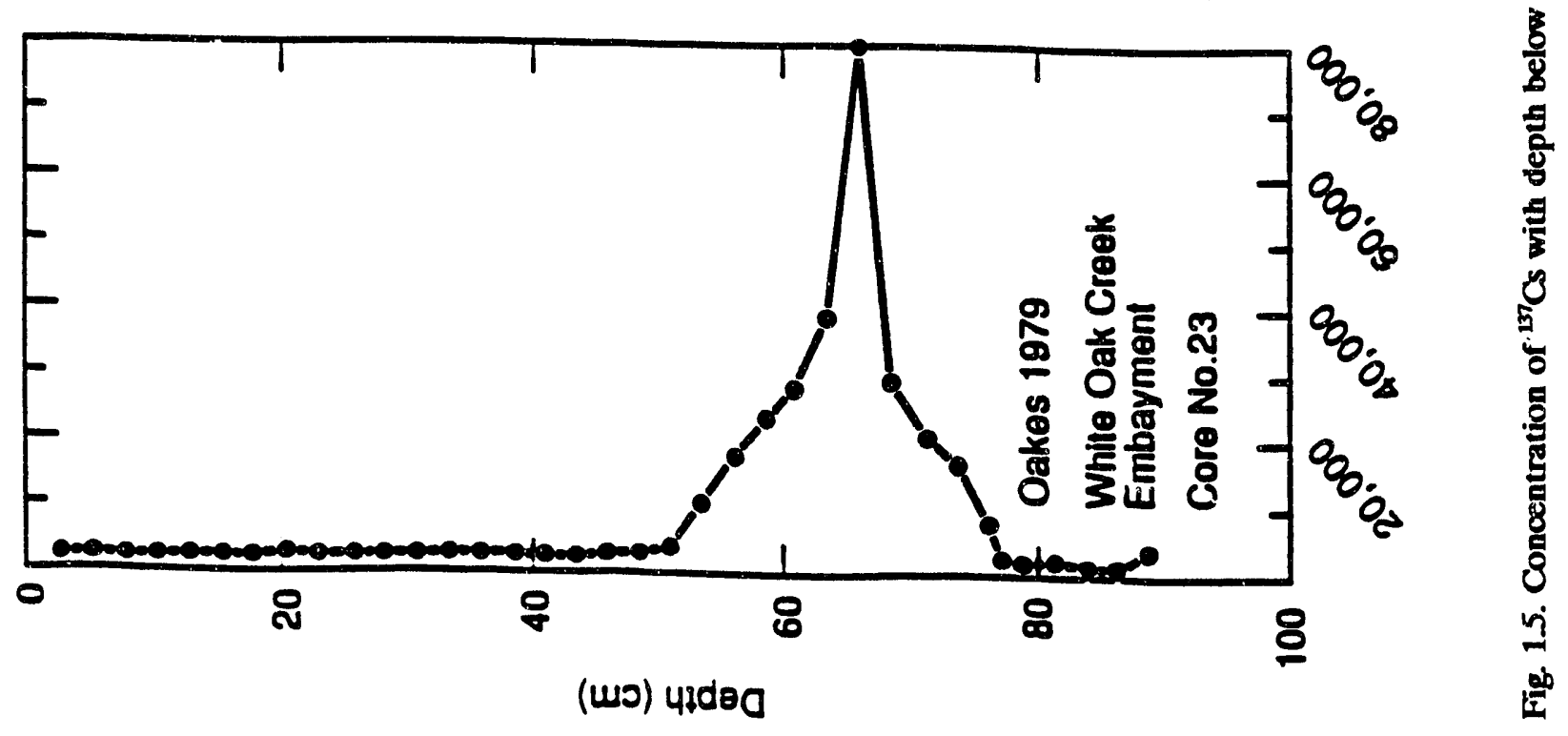



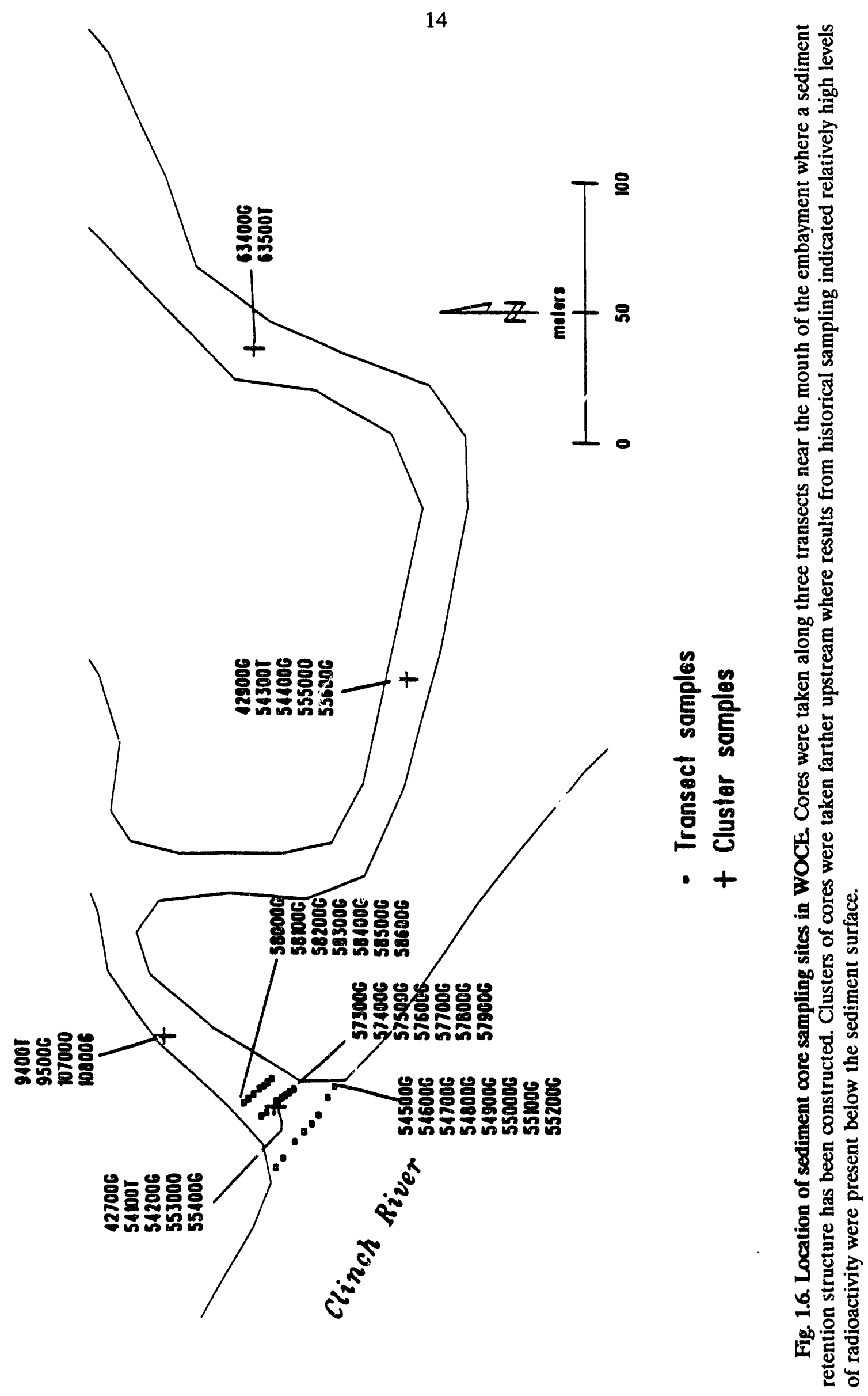
mean concentrations for ${ }^{239-240} \mathrm{Pu}$ and ${ }^{90} \mathrm{Sr}$ in core $9500 \mathrm{G}$ are about an order of magnitude greater than the concentrations reported by TVA. in 1986 (Table 1 of Appendix B).

To determine the spatial distribution of the surface sediment radioactivity in the embayment, 31 sediment grab samples were collected near the mouth of the embayment on August 30, 1990 (Fig. 1.7), and 41 grab samples were collected from the upper portion of the embayment on September 18, 1990 (Fig. 1.8). These samples were analyzed for gamma-emitting radioactivity and the concentrations of ${ }^{60} \mathrm{Co}$ and ${ }^{137} \mathrm{Cs}$ in these samples are given in Table D2. Concentrations of ${ }^{60} \mathrm{Co}$ in the surface sediment ranged from less than detectable to about $6 \times 10^{3} \mathrm{~Bq} / \mathrm{kg}$ dry wt $\left(1.6 \times 10^{2} \mathrm{pCi} / \mathrm{g}\right.$ dry wt $)$ with a mean concentration of about $9 \times 10^{2} \mathrm{~Bq} / \mathrm{kg}$ dry wt $\left(2.4 \times 10^{1} \mathrm{pCi} / \mathrm{g}\right.$ dry wt $)$. Concentrations of ${ }^{137} \mathrm{Cs}$ ranged from about $1.5 \times 10^{2}$ to $1.1 \times 10 \mathrm{~Bq} / \mathrm{kg}$ dry wt $\left(4.0 \times 10^{\mathrm{C}}\right.$ to $2.9 \times 10^{4} \mathrm{pCi} / \mathrm{g}$ dry wt $)$ with a mean concentration of $-1.0 \times 10^{5} \mathrm{~Bq} / \mathrm{kg}$ dry wt $\left(2.7 \times 10^{3} \mathrm{pCi} / \mathrm{g}\right.$ dry wt $)$. Although the concentrations of ${ }^{137} \mathrm{Cs}$ in the surface sediment samples did not exceed the concentrations in the $9500 \mathrm{G}$ core samples, results from the surface sediment analyses confirmed that relatively high levels of ${ }^{137} \mathrm{Cs}$ activity existed at the sediment surface over an area extending from the mouth to $0.25 \mathrm{~km}$ upstream. For example, samples $30500 \mathrm{~B}$ and $31600 \mathrm{~B}$ (Fig. 1.7) had ${ }^{137} \mathrm{Cs}$ concentrations of $4.4 \times 10^{5}$ and $7.9 \times 10^{5} \mathrm{~Bq} / \mathrm{kg}$ dry wt $\left(1.2 \times 10^{4}\right.$ and $\left.2.1 \times 10^{4} \mathrm{pCi} / \mathrm{g} \mathrm{dry} \mathrm{wt}\right)$, respectively.

\subsubsection{Estimated Inventories of Radionuclides in Embayment Sediment}

Data from 78 samples (72 plus 6 additional) of surface sediment (Appendix D) together with data from historical and recent sediment cores were used to estimate inventories for the radioactive contaminants that reside in the embayment sediment. To obtain as accurate an inventory as possible, the embaynent was divided into six sections (Fig. 1.4) and an inventory was calculated for each section. Surface sediment samples were taken throughout the embayment (Figs. 1.7 and 1.8) but only historical core data were available for Sections A, B, and C. Data from recent core samples taken along transects (Fig. 1.6) showed that the contamination extended to a depth of $\sim 1 \mathrm{~m}$ within the main stream channel, but outside the channel most of the contamination was in the top few centimeters of sediment (Figs. D1, D2, and D3). Therefore, an inventory was calculated for the radionuclides in the top $12 \mathrm{~cm}$ of embayment sediment and another for the radionuclides in the stream channel.

The radionuclide inventories for the surface sediment in Sections $D, E$, and F was based on the average concentration of the radionuclides in the surface samples together with the concentration in the upper $12 \mathrm{~cm}$ of the core samples taken in the same section. Because only historical core data were available for Sections A, B, and C, only the surface grab sample data were used to calculate the surface sediment inventory for these sections. The average surface sediment concentration $(\mathrm{Bq} / \mathrm{kg}$ ) for each section was multiplied by (1) the volume of sediment in the top $12 \mathrm{~cm}$ of each section and (2) the density of the sediment $\left(1.3 \mathrm{~g} / \mathrm{cm}^{3}\right)$ to provide an estimate of the radionuclide inventory. It was estimated that $-1.2 \mathrm{Ci}$ of ${ }^{137} \mathrm{Cs}$ are present in the surface sediments of the embayment.

Data from 31 cores from Sections D, E, and F (Figs. 1.4 and 1.6) were available to estimate the inventory of radionuclides in the stream channel. The majority of these cores were taken in Section $F$ where the coffercell-type sediment-retention structure is being constructed. Based on results if core samples taken along transects across the embayment, the width of the stream channel in Sections D, E, and F was assumed to be one-third the width of the embayment. The inventory of the stream channel was estimated by using the 


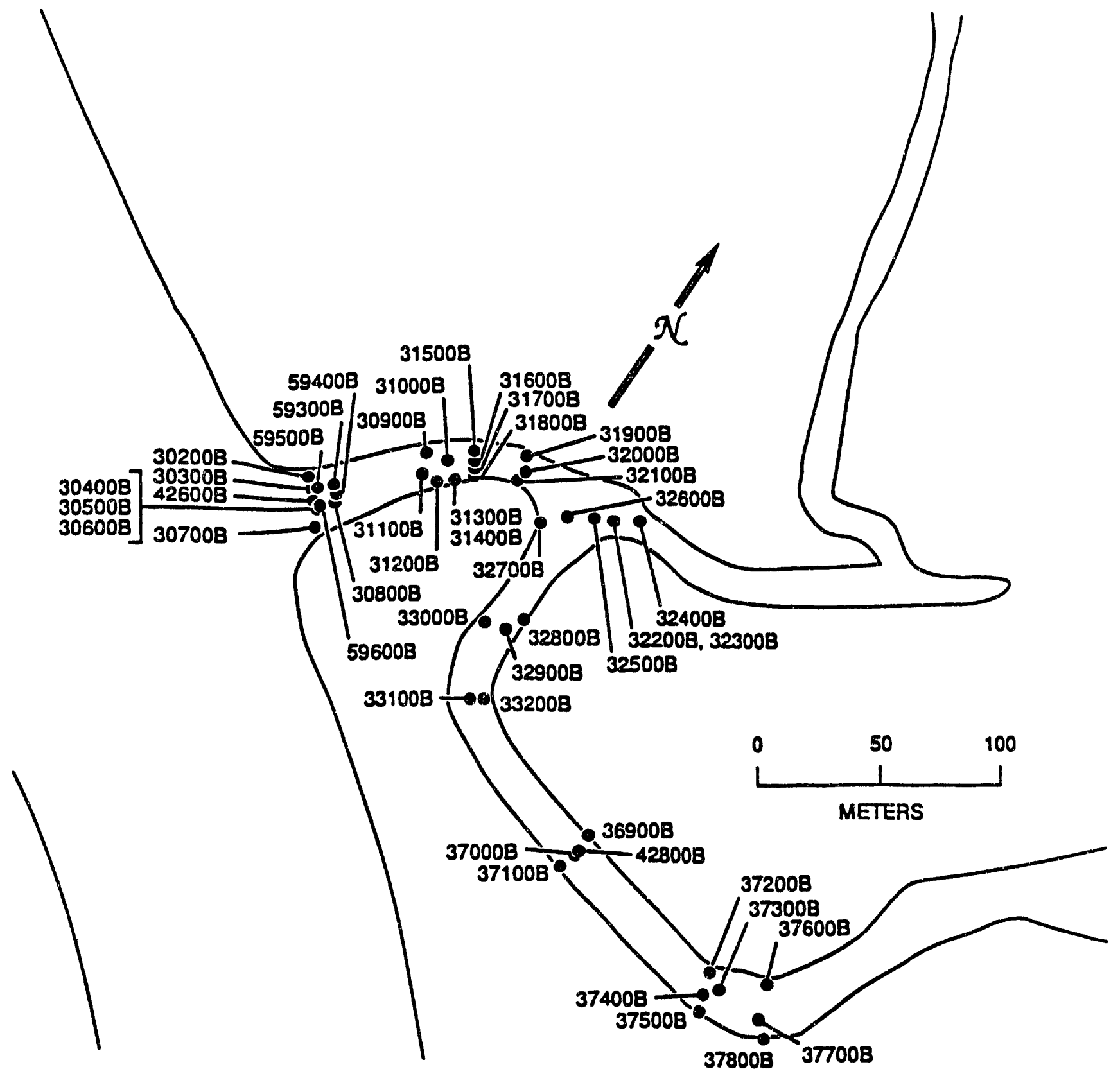

Fig. 1.7. Locations where surface sediment grab samples were collectid in 1990 and 1991 from the lower end of WOCE. 


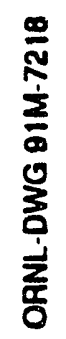

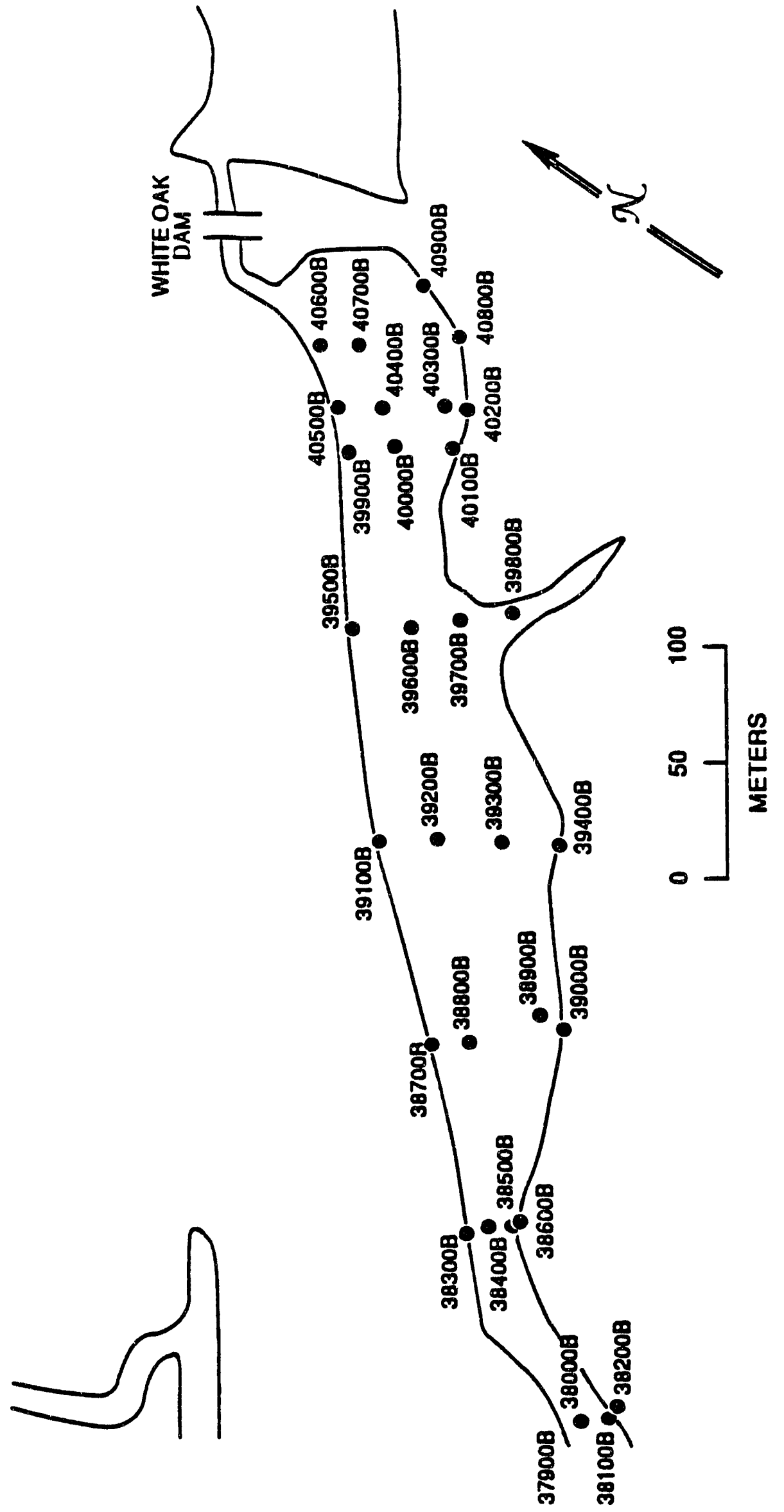

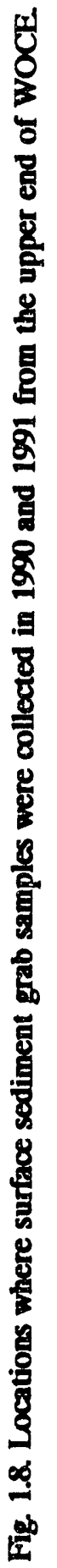


diameter of the cores to calculate the concentration of the radionuclides on an area basis and then obtaining the mean concentration per $\mathrm{m}^{2}$ for each section. $\mathrm{U}$ sing this procedure, an estimate of $4.5 \mathrm{Ci}$ of ${ }^{137} \mathrm{Cs}$ was obtained for the stream channel in Sections D, E, and F. Using the same procedure but substituting the concentration per $\mathrm{m}^{2}$ for ${ }^{137} \mathrm{Cs}$ in core $9500 \mathrm{G}$ for the average concentration yields a stream channel inventory of $9.7 \mathrm{Ci}$ of ${ }^{137} \mathrm{Cs}$ for these sections.

Because the core data for Sections A, B, and C were historical and limited, the radionuclide inventory for the upper sections of the stream channel was based on the concentration $(\mathrm{Bq} / \mathrm{kg})$ of the radionuclides in the sediment following the procedure used for the surface samples. The area of the stream channel in Sections A, B, and C was based on the width of the stream at the winter pool level $(733 \mathrm{ft} \mathrm{MSL})$. The estimated inventory of ${ }^{137} \mathrm{Cs}$ for the stream channel in Sections A, B, and C is $1.7 \mathrm{Ci}$. If the inventory of ${ }^{137} \mathrm{Cs}$ in the surface sediment is combined with the inventory for the entire stream channel based on average concentrations, the total ${ }^{137} \mathrm{Cs}$ inventory for the embayment sediment is $6.6 \mathrm{Ci}$; however, using the inveniory value for the stream channel in Sections $D, E$, and $F$ based on the concentration per $\mathrm{m}^{2}$ in core $9500 \mathrm{G}$ would result in an estimate of $11.8 \mathrm{Ci}$ of ${ }^{137} \mathrm{Cs}$ in the sediment.

Using the same methods described above, the estimated inventory for ${ }^{60} \mathrm{Co}$ in the embayment ranges from $0.06 \mathrm{Ci}$ using mean values to $0.09 \mathrm{Ci}$ using the value from core $9500 \mathrm{G}$. Inventories for other radionuclides in the sediment are based on data from core $9500 \mathrm{G}$ and historical data from cores taken several years earlier (Table 1 of Appendix B). Estimated inventories for radionuclides in the embayment sediment are given in Table 1.4.

Considerable uncertainty is associated with estimating the inventory of radionuclides in the sediment of the embayment because of the heterogeneous distribution of the radionuclides. The uncertainty of the estimates is also compounded by the fact that a limited number of core samples from the upper section of the embayment were available for analysis and that few samples were analyzed for ${ }^{90} \mathrm{Sr}$ and transuranic radionuclides. The uncertainty associated with the estimated inventories for Sections $\mathrm{A}, \mathrm{B}$, and $\mathrm{C}$ could be reduced by collecting additional cores along the stream channel in these sections. A "walk over" radiation survey (Sect. 1.3.9) revealed a relatively high external exposure rate $\left(3 \mathrm{mR} \mathrm{h}^{-1}\right)$ at one location along the str $n$ channel in Section $A$ which suggests that the inventory of ${ }^{137} \mathrm{Cs}$ for this section may be underestimated. Greatest confidence can be placed on the estimated ${ }^{137} \mathrm{Cs}$ and ${ }^{60} \mathrm{Co}$ inventories for Section $F$ where the largest number of cores were collected.

\subsubsection{Organic Contaminants in White Oak Creek Embayment Sediments}

Data for organic and inorganic contaminants in WOCE are more limited than data for radionuclides. Analyses for polychlorinated biphenyls (PCBs) in White Oak Lake, White Oak Creek above the lake, and Melton Branch clearly indicate that the White Oak Creek system is contaminated with PCBs (Boyle et al. 1982). An average concentration of $0.5 \mu \mathrm{g} / \mathrm{g}$ dry wt of PCBs was detected in WOCE sediment during monitoring in 1974-1975 (ERDA 1975). In 1984, TVA sampled sediments in WOCE as part of the Oak Ridge Task Force Study (TVA 1985a,b). PCBs were not detected in samples from three of four cores; however, TVA core White Oak Creek 0.18 (Fig. 1.4) contained $2.8 \mu \mathrm{g} / \mathrm{g}$ dry wt of PCBs (TVA 1985a,b). In addition to PCB analyses, composite samples from the sediment cores collected by TVA were analyzed for 43 other organic contaminants (Appendix B). Concentrations of all of these contaminants were less than detectable except for bis (2-ethylhexyl) phthalate, which was detected at a concentration of $1.6 \mu \mathrm{g} / \mathrm{g}$ dry wt in TVA core White Oak Creek 0.55 (Fig. 1.4). 
Table 1.4. Estimated inventory of various radionuclides in WOCE sediments

\begin{tabular}{|c|c|c|c|}
\hline Radionuclide & $\begin{array}{l}\text { Total } \mathrm{Ci}^{a} \\
\text { (mean) }\end{array}$ & $\begin{array}{c}\text { Total } \mathrm{Ci}^{a} \\
\text { (maximum) }\end{array}$ & $\begin{array}{l}\text { Percent of total } \\
\text { activity }\end{array}$ \\
\hline Cs-137 & 6.6 & $(11.8)$ & 95 \\
\hline Co- 60 & 0.06 & $(0.09)$ & 1 \\
\hline Sr $-90^{b}$ & 0.2 & & 3 \\
\hline Am-241 ${ }^{b}$ & 0.009 & & 0 \\
\hline $\mathrm{Cm}-244^{b}$ & 0.001 & & 0 \\
\hline $\mathrm{Pu}-238^{b}$ & 0.002 & & 0 \\
\hline Pu-239, 240 & 0.056 & & 1 \\
\hline $\mathrm{U}-234^{b}$ & 0.005 & & 0 \\
\hline $\mathrm{U}-235^{b}$ & 0.005 & & 0 \\
\hline U-238 & 0.003 & & 0 \\
\hline Total activity & 6.9 & & \\
\hline
\end{tabular}

Sediment core 107000 (a split of 10800G) (Fig. 1.6), collected as part of the Clinch River RI Phase I sampling (Energy Systems 1990), was analyzed for inorganic and organic contaminants. The cores were sectioned into 4-cm lengths, and each section was analyzed to determine the concentration of pollutants with depth. The samples were analyzed for a total of 85 organic contaminants including PCBs. Of these contaminants, only PCBs and diethylphthlate were above the limits of detection for the analytical methods used. A summary of the data showing the mean values and ranges is given in Appendix C.

Two additional sediment cores (553000 and 555000, splits of 55400G and 55600G, respectively) were collected in January 1991 from different sections of WOCE (Fig. 1.6) and analyzed for organic contaminants. These cores were sectioned into 4-cm lengths and each section was analyzed for 91 organic contaminants. Only five contaminants were above the limits of detection: Aroclor-1260, bis (2-ethylhexyl) phthalate, fluoranthene, phenanthrene, and pyrene. Although these organic compounds were detected, the reported values are estimates because the concentrations were less than the contract-required quantitation limits. A summary of the data for these cores is provided in Table 2 of Appendix C.

\subsubsection{Inorganic Contaminants in White Oak Creek Embayment Sediments}

Composite samples from four sediment cores collected by TVA in 1984 (TVA 1986) were analyzed for metals by available inductively coupled plasma and absorption spectrometry methodologies. A summary of these data is given in Appendix B. Metals having the highest mean concentrations in the cores were chromium, lead, nickel, and zirconium. Mercury had a mean concentration in sediment of $3.4 \pm 1.7 \mathrm{mg} / \mathrm{kg}$ dry wt and a maximum value of 
$6.0 \mathrm{mg} / \mathrm{kg}$; arsenic had a mean concentration of $8.3 \pm 3.8 \mathrm{mg} / \mathrm{kg}$ dry $\mathrm{wt}$ and a maximum value of $12.0 \mathrm{mg} / \mathrm{kg}$ dry wt.

A summary of the data from sediment core $9400 \mathrm{~T}$ (a split of $9500 \mathrm{G}$ ) is given in Appendix C. Metals having the highest mean concentrations in this sediment core were zinc, mercury, lead, chromium, copper, and nickel, respectively. The mean concentrations of metals in core 9400T were much higher than the mean concentrations in the four TVA cores, except for arsenic, which was lower. The mean concentration for arsenic was $4.0 \pm 1.7 \mathrm{mg} / \mathrm{kg}$ dry wt with a maximum value of $7.6 \mathrm{mg} / \mathrm{kg}$ dry wt. Concentrations of mercury and lead were greater than $100 \mathrm{mg} / \mathrm{kg}$ dry wt in the top four $\mathrm{cm}$ of core $9400 \mathrm{~T}$. The concentration of mercury in core $9400 \mathrm{~T}$ is relatively high in comparison to most other metals detected in the core sample. The highest concentration ( $360 \mathrm{mg} / \mathrm{kg}$ dry wt) occurred at a depth of $36 \mathrm{~cm}$ (Fig. 1.9). Because of the limited number of metal analyses, the variability observed in the concentrations, and the high concentrations observed in core $9400 \mathrm{~T}$, it was determined that additional samples were needed.

Three additional sediment cores (54100T, 54300T, and 63500T) collected from different locations in WOCE (Fig. 1.5) after July 1990 were analyzed for inorganic contaminants. Methods used to analyze these cores were similar to those used for core $9400 \mathrm{~T}$. In most instances, the mean and maximum values for inorganics reported for core $9400 \mathrm{~T}$ are greater than the values reported for the three additional cores (Tables 1 and 2 of Appendix C). An exception to this observation is arsenic, which showed a maximum of $17.4 \mathrm{mg} / \mathrm{kg}$ and a mean of $4.6 \pm 2.7 \mathrm{mg} / \mathrm{kg}$, values that are slightly higher than previously reported. The mean value for lead in core $9400 \mathrm{~T}$ was much higher $(66.1 \mathrm{mg} / \mathrm{kg}$ dry wt) than the mean in the three additional cores $(34.9 \mathrm{mg} / \mathrm{kg}$ dry $\mathrm{wt})$. The maximum value $(156 \mathrm{mg} / \mathrm{kg}$ dry wt) for lead occurred at a depth of 12 to $16 \mathrm{~cm}$ in core 54300T. Profiles of the distribution of arsenic, lead, and mercury with sediment depth for cores $9400 \mathrm{~T}, 54100 \mathrm{~T}$, and $54300 \mathrm{~T}$ are shown in Fig. 1.9.

Mean sediment values for zinc were the same for core $9400 \mathrm{~T}$ and the other cores (Tables $\mathrm{C} 1$ and C2). A maximum concentration of $403 \mathrm{mg} / \mathrm{kg}$ was found at a depth of 100 to $104 \mathrm{~cm}$ in core 54300T. Because this value is about a factor of 4 higher than the maxima for the other cores, the maximum value is possibly an artifact. Concentrations of mercury in core $9400 \mathrm{~T}$ are unusually high in comparison to the concentrations found in the other three cores. The mean mercury concentration for core $9400 \mathrm{~T}$ is more than an order of magnitude greater than the mean values for the other cores (Tables $\mathrm{C} 1$ and $\mathrm{C2}$ ) and the maximum is about a factor of 6 greater. The high value for core 9400T appears to be an isolated deposit of mercury. An estimate of the average concentration of mercury in the embayment sediment based on data from the three cores (54100T, 54300T, and 63500T) would be much lower than an estimate based on the mercury concentration reported for core $9400 \mathrm{~T}$.

\subsubsection{Classification of Potential Waste from White Oak Creek Embayment Sediments}

The discovery of elevated levels of radionuclides and inorganic contaminants (using conventional analytical techniques) in WOCE complicated the waste classification of the sediment. Sediment waste from the construction of the sediment retention structure must be categorized, for waste management and health and safety concerns, as either low-level radioactive waste (LLW) or mixed waste (containing LLW and inorganic contaminants). A designation of the embayment sediment as mixed waste would present difficulties in managing waste generated by construction activities. The Toxicity Characteristic Leachate Procedure 

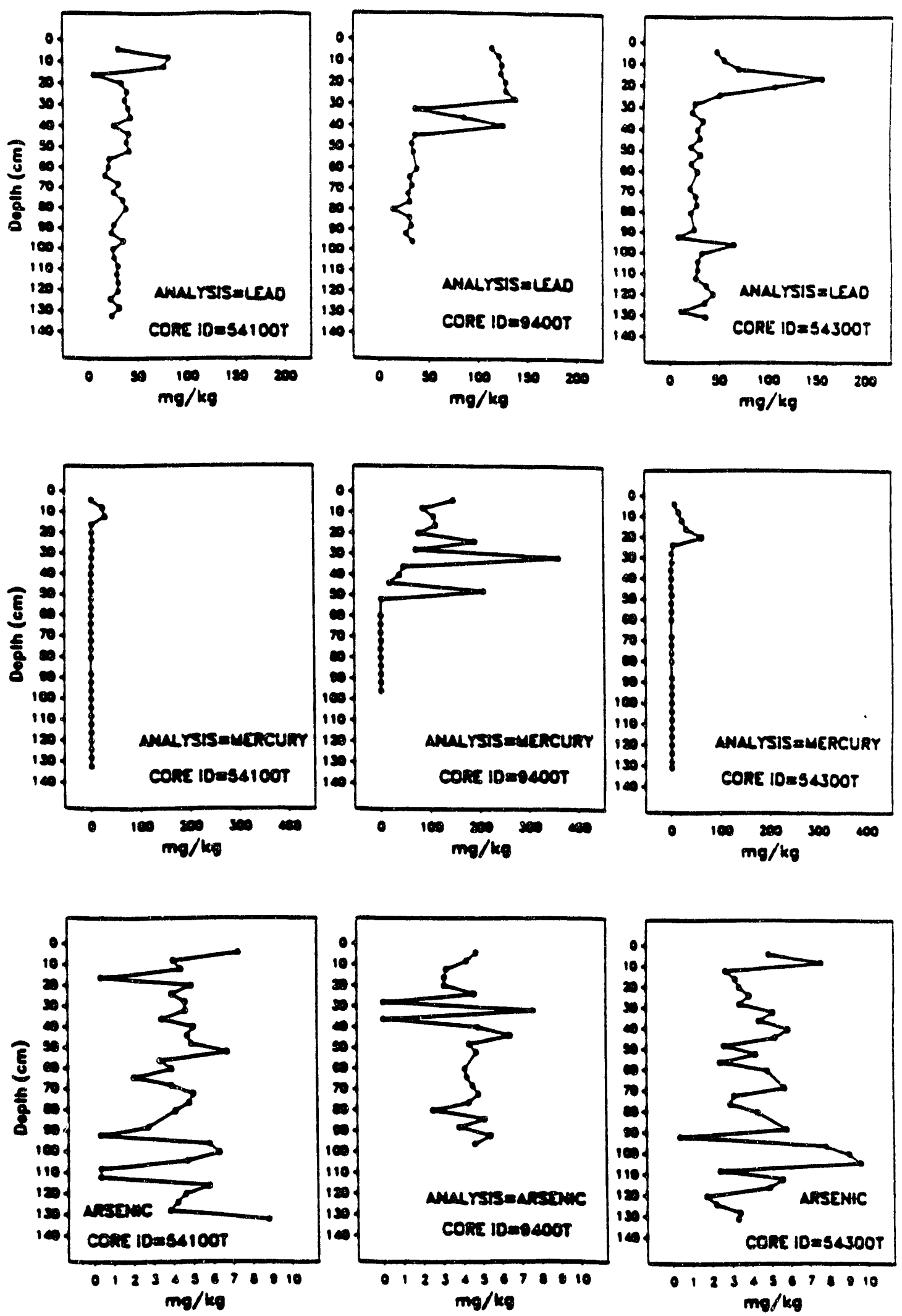

Fig 1.9. Profiles of the distribution of arsenic, lead, and mercury by depth in three sediment cores. 
(TCLP) is mandated by EPA as a method for waste characterization (Federal Register, 1990a, $1990 \mathrm{~b}$ ). Samples were screened by conventional analytical procedures prior to submittal for TCLP analysis. If the concentration of a contaminant in a sample was close to or above the guidance level for solid materials given in the Federal Register (1990b), the TCLP was performed. Results from the TCLP analyses showed that the embayment sediments do not fall into the category of mixed waste. A more detailed discussion of the TCLP, analytical results, and sample locations is given in Appendix M.

\subsubsection{Water Analyses}

A National Pollutant Discharge Elimination System and radiological monitoring station has been located at White Oak Dam for many years. Water samples are analyzed for anions, metals, organics (chloroform, total PCBs, and trichloroethylene), radionuclides (gross beta, gross alpha, total strontium, and seven specific radionuclides), and water quality parameters. A summary of the data collected from January 1989 to September 1990 is given in Table 1 of Appendix E. The concentration of tritium was higher than that of any of the other radionuclides analyzed in the water samples at White Oak Dam, reaching a maximum concentration of $1.6 \times 10^{4} \mathrm{~Bq} / \mathrm{L}\left(4.3 \times 10^{2} \mathrm{pCi} / \mathrm{mL}\right)$.

A Clinch River RI water sample was collected $\sim 50 \mathrm{~m}$ upstream from the mouth of White Oak Creek in February 1990 and analyzed for organics, metals, and radionuclides. The results of these analyses are summarized in Table 1 of Appendix F. Total and dissolved metal concentrations were determined. Concentrations of all organics for which analyses were conducted were less than detection limits. Of the 13 metals for which analyses were conducted, only zinc and chromium were above the limits of detection; zinc had the higher concentration. Tritium and ${ }^{90} \mathrm{Sr}$ were the most abundant radionuclides in the water with approximate concentrations of $1 \times 10^{4}$ and $8 \times 10^{\circ} \mathrm{Bq} / \mathrm{L}\left(3 \times 10^{2}\right.$ and $\left.2 \times 10^{-1} \mathrm{pCi} / \mathrm{mL}\right)$, respectively. Concentrations are considered approximate and of limited use because of incorrect preservation of the samples before analysis; therefore, they should not be used outside of this report. The Clinch River RI values are, however, well within the range of observed concentrations from ORNL radiological monitoring activities.

\subsubsection{Aquatic Biota in White Oak Creek Embayment}

Sampling of biota in the WOCE for radiological and chemical analyses has focused primarily on fish; however, biota in White Oak Lake have been more intensively sampled, and invertebrates, aquatic macrophytes, turtles, waterfowl, and fish have been analyzed. Most analyses in the past were for radionuclides, but recently more emphasis has been placed on PCBs, mercury, and other metals. In general, the concentration of contaminants in biota in White Oak Lake is greater than in biota in WOCE because of the higher environmental concentrations of contaminants in the lake; however, PCBs are an exception [Loar (ed) 1989]. Previous analyses of fish from WOCE have shown that the primary contaminants above background levels are PCBs, chlordane, mercury, ${ }^{60} \mathrm{Co},{ }^{137} \mathrm{Cs}$, and ${ }^{90} \mathrm{Sr}$ [Loar (ed) 1989, 1990].

Three species of fish from WOCE were analyzed for either organics, metals, or radionuclides following guidelines found in the Clinch River RI Phase I sampling plan (Energy Systems 1990). These data are summarized in Table 1 of Appendix G. Bluegill (Lepomis macrochirus) were analyzed for metals and ${ }^{137} \mathrm{Cs}$. Catfish (Ictalurus punctatus) were analyzed for organics, including PCBs, and for ${ }^{60} \mathrm{Co},{ }^{137} \mathrm{Cs}$, ${ }^{90} \mathrm{Sr}$, and ${ }^{235} \mathrm{U}$. Largemouth bass (Micropterus salmoides) were analyzed for a selected list of contaminants including metals and 
${ }^{137} \mathrm{Cs}$. Bluegill have a small home range and usually remain in the same area; therefore, they are considered good indicators of contaminants in a particular stretch of a stream. Catfish are benthic feeders, have a high lipid content, tend to accumulate PCBs and other organic contaminants, and should contain the highest concentration of organic contaminants. Largemouth bass represent top predators in the food chain and should serve as indicators of contaminants that accumulate through the food chain. Additionally, these three species are commonly consumed by the general public and are representative of different trophic levels.

Six to ten individuals of each species were analyzed for the various contaminants; however, for some organic contaminants only two largemouth bass were analyzed. Concentrations of the primary contaminants (PCBs, mercury, arsenic, ${ }^{137} \mathrm{Cs}$, and ${ }^{90} \mathrm{Sr}$ ) in these samples were similar to those reported previously [Loar (ed) 1989, 1990].

\subsubsection{External Radiation Survey}

A walkover gamma radiation survey was conducted inside the fenced area surrounding WOCE in October and November 1990 by the Measurement Applications and Development group of the Health and Safety Research Division (Patania 1991a). This survey was designed to provide a rapid estimate of the extent of surface contamination by measuring the radiation emitted by gamma-emitting radionuclides. During this survey, the water was at summer-pool level (741 ft MSL) and the upper end of the embayment was covered with water.

A second survey began in February 1991 (Patania 1991b) to determine the radiation exposure rates associated with the embayment at the winter-pool level ( $733 \mathrm{ft}$ MSL) when much of the embayment sediment is exposed. Unfortunately, this low-water survey had to be terminated at the end of March 1991 as a result of weather conditions and increasing water levels. Consequently, only the upper two-thirds of the north side of the embayment was surveyed at the winter-pool level.

The survey technique consisted of a gamma radiation survey at $1 \mathrm{~m}$ above the soil surface with hand-held gamma scintillometers over the entire accessible area on both bar: of the embayment. A pressurized ionization chamber was used to quantify the exposure rate indicated by the scintillometers. No ground-level contamination survey was conducted, nor were sediment samples taken for analysis in conjunction with the surveys.

The gamma survey conducted when the water was at the summer pool level indicated elevated exposure rates throughout $\sim 80 \%$ of the length of the embayment, restricted primarily to the shorelines and other low-lying areas where sediment deposition by embayment water is likely. The exposure rates, ranged from 19.0 to $318 \mu \mathrm{R} / \mathrm{h}$, and a general pattern of exposure is shown in Fig. 1.10. A 1-year continuous exposure at $318 \mu \mathrm{R} / \mathrm{h}$ is approximately equivalent to a $2 \times 10^{-3}$ lifetime risk of excess cancer incidence (using a risk coefficient of $7.2 \times 10^{-4}$ per rem). Natural background in the vicinity of the embayment ranged from 7.0 to $12.0 \mu \mathrm{R} / \mathrm{h}$. A 1 -year exposure at the background rate is approximately equivalent to a lifetime risk of excess cancer incidence of $4 \times 10^{-5}$ to $1 \times 10^{-4}$. The highest exposure rate of $318 \mu \mathrm{R} / \mathrm{h}$ was located at a spot on the north bank of the embayment in the vicinity of the area where the higher levels of ${ }^{137} \mathrm{Cs}$ were found in sediment cores by Oakes et al. (1982b) and TVA (1984) (Fig 1.4). Levels of exposure at the mouth of the embayment and adjacent banks of the Clinch River both upstream and downstream ranged from 11 to $107 \mu \mathrm{R} / \mathrm{h}$.

The exposure rates at the winter pool level ranged from 47 to $3000 \mu \mathrm{R} / \mathrm{h}$ and were highest near the stream channel. A general pattern of exposure rates for the area on the north side 
of the embayment that is above the summer water level is shown in Fig. 1.11. At the winter pool level, when more of the embayment sediment is exposed, the exposure rate at the security fence on the north side reaches $60 \mu \mathrm{R} / \mathrm{h}$ (Fig. 1.11); whereas, at the summer-pool level, the exposure rate at the same location is $<25 \mu \mathrm{R} / \mathrm{h}$ (Fig. 1.10). The higher exposure rate at the winter pool level results from the gamma radiation coming from the exposed bottom sediments in the floodplain.

A pattern of exposure rates for the north side of the exposed floodplain at winter pool level is shown in Fig. 1.12. Exposure rates ranged from 200 to $3000 \mu \mathrm{R} / \mathrm{h}$ near the stream channel for the portion of the floodplain that was surveyed. The highest exposure rates (1500 to $3000 \mu \mathrm{R} / \mathrm{h}$ ) occurred in a small area along the stream channel about $100 \mathrm{~m}$ downstream from White Oak Dam and Highway 95 (Fig. 1.12). A one-year continuous exposure at $3,000 \mu \mathrm{R} / \mathrm{h}$ is approximately equivalent to a $1.9 \times 10^{-2}$ lifetime risk of excess cancer incidence. Concentrations of ${ }^{137} \mathrm{Cs}$ in surface sediment grab samples $(40100 \mathrm{~B}, 40100 \mathrm{~B}$, and $40300 \mathrm{~B}$ ) from this area ranged from $4 \times 10^{4}$ to $8.5 \times 10^{4} \mathrm{~Bq} / \mathrm{kg}$ dry weight. A sediment core is needed from this area to determine the distribution of gamma-emitting radionuclides with depth. The area of the embayment south of the stream channel was not surveyed for gamma radiation because of rising water levels.

\subsubsection{Source of ${ }^{137} \mathrm{Cs}$ in White Oak Creek Embayment Sediments}

Cesium-137 released over White Oak Dam either in solution or associated with suspended solids is the primary source of ${ }^{137} \mathrm{Cs}$ in WOCE sediments. When released over White Oak Dam, ${ }^{137} \mathrm{Cs}$ is either deposited in the sediment of WOCE or transported into the Clinch River. The relatively high concentration of ${ }^{137} \mathrm{Cs}$ found at a depth of $63 \mathrm{~cm}$ in core no. 23 taken in 1979 (Oakes et al. 1982b) and at a depth of $25 \mathrm{~cm}$ in TVA core 0.18 (TVA 1984) (Fig. 1.5) suggests that these concentrations represent past releases. The relatively high concentrations of ${ }^{137} \mathrm{Cs}$ observed at the sediment surface in core $9500 \mathrm{G}$ taken June 1990 as part of the Clinch River RI Phase-1 sampling (Fig. 1.6) and in the surface sediment grab samples taken near the mouth of White Oak Creek (Fig. 1.7) suggest either that relatively high levels of ${ }^{137} \mathrm{Cs}$ have been released over White Oak Dam in recent years or that sediments deposited in previous years have been redistributed. Annual release records of ${ }^{137} \mathrm{Cs}$ at White Oak Dam (Table 1.1) and recent monitoring data (Table E1) indicate that recent releases are unlikely to be responsible for the concentrations in the surface sediments at the mouth of White Oak Creek. In addition, it is unlikely that resuspension of White Oak Lake sediments during storm events is the source of the ${ }^{137} \mathrm{Cs}$, because the current concentration of ${ }^{137} \mathrm{Cs}$ in surface sediments in White Oak Lake ranges from $1 \times 10^{5}$ to $2 \times 10^{5} \mathrm{~Bq} / \mathrm{kg}$ dry wt $\left(3 \times 10^{3}\right.$ to $5 \times 10^{3} \mathrm{pCi} / \mathrm{g}$ dry wt) [Loar (ed) 1989]. Data in Table 1.1 show that most of the ${ }^{137} \mathrm{Cs}$ was released from White Oak Lake from 1954 to 1957 . The greatest release $(170 \mathrm{Ci})$ occurred in 1956 as a result of flooding that scoured highly contaminated sediment from the lake bed after White Oak Lake was drained in 1955.

All evidence supports the conclusion that relatively high concentrations of ${ }^{137} \mathrm{Cs}$ in the surface sediment near the mouth of WOCE are from past releases. Some of the highly contaminated sediment from White Oak Lake was deposited in depositional zones of WOCE where it continued to be covered by less contaminated sediment. Normal erosion processes, especially during storm events, undoubtedly resulted in the redistribution and downstream transport of embayment sediment. When Melton Hill Dam became operational in 1963, fluctuating water levels and flow reversals (Fig. 1.3) associated with power generation resulted in daily flooding and draining of mud flats during winter pool conditions and likely contributed to the erosion and redistribution of sediments in the embayment. 


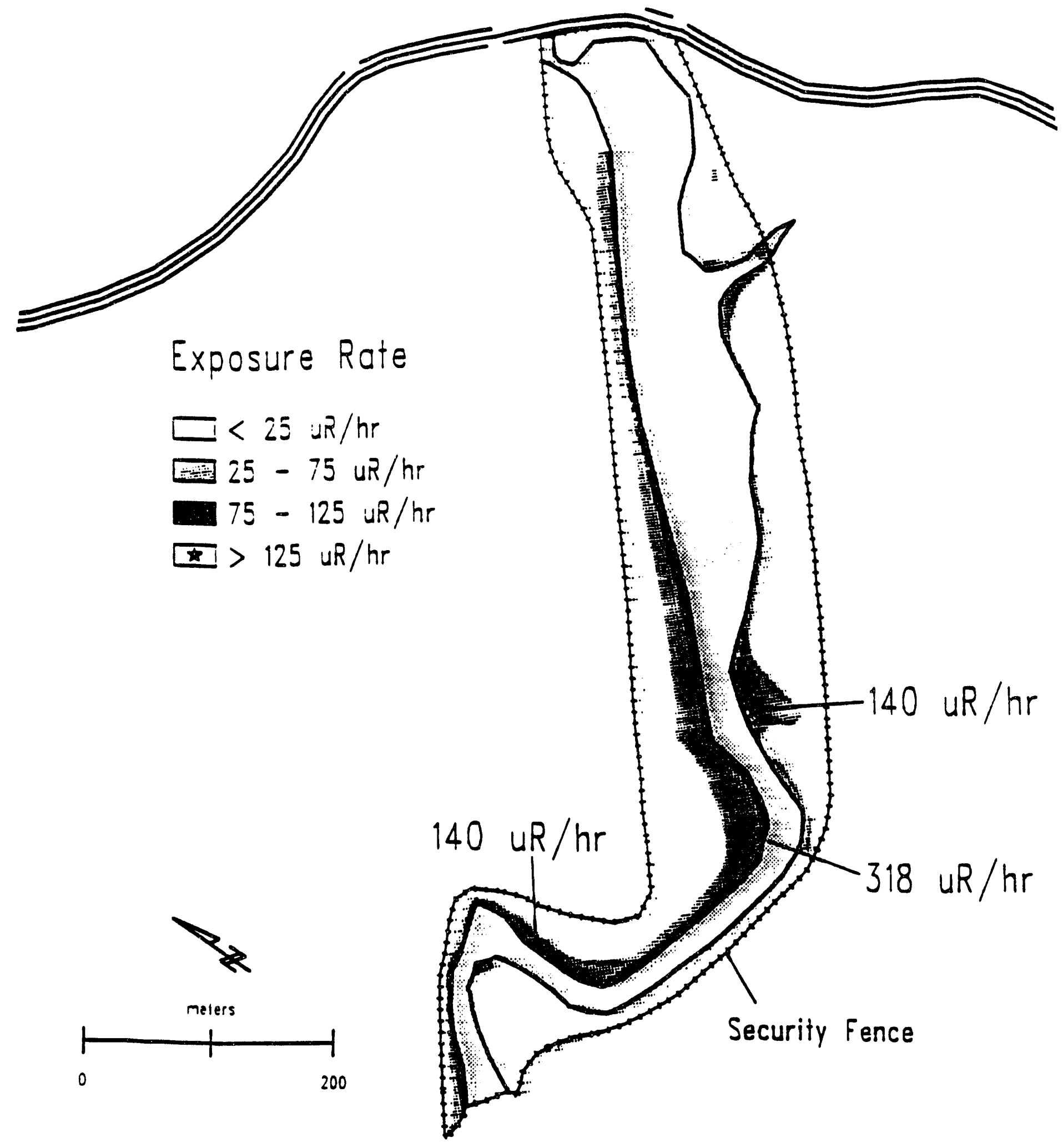

Fig. 1.10 Survey of gamma (primarily ${ }^{37} \mathrm{Cs}$ ) radiation exposure rates measured $1 \mathrm{~m}$ above the ground surface along the banks of WOCE when water was at full-pool level. 


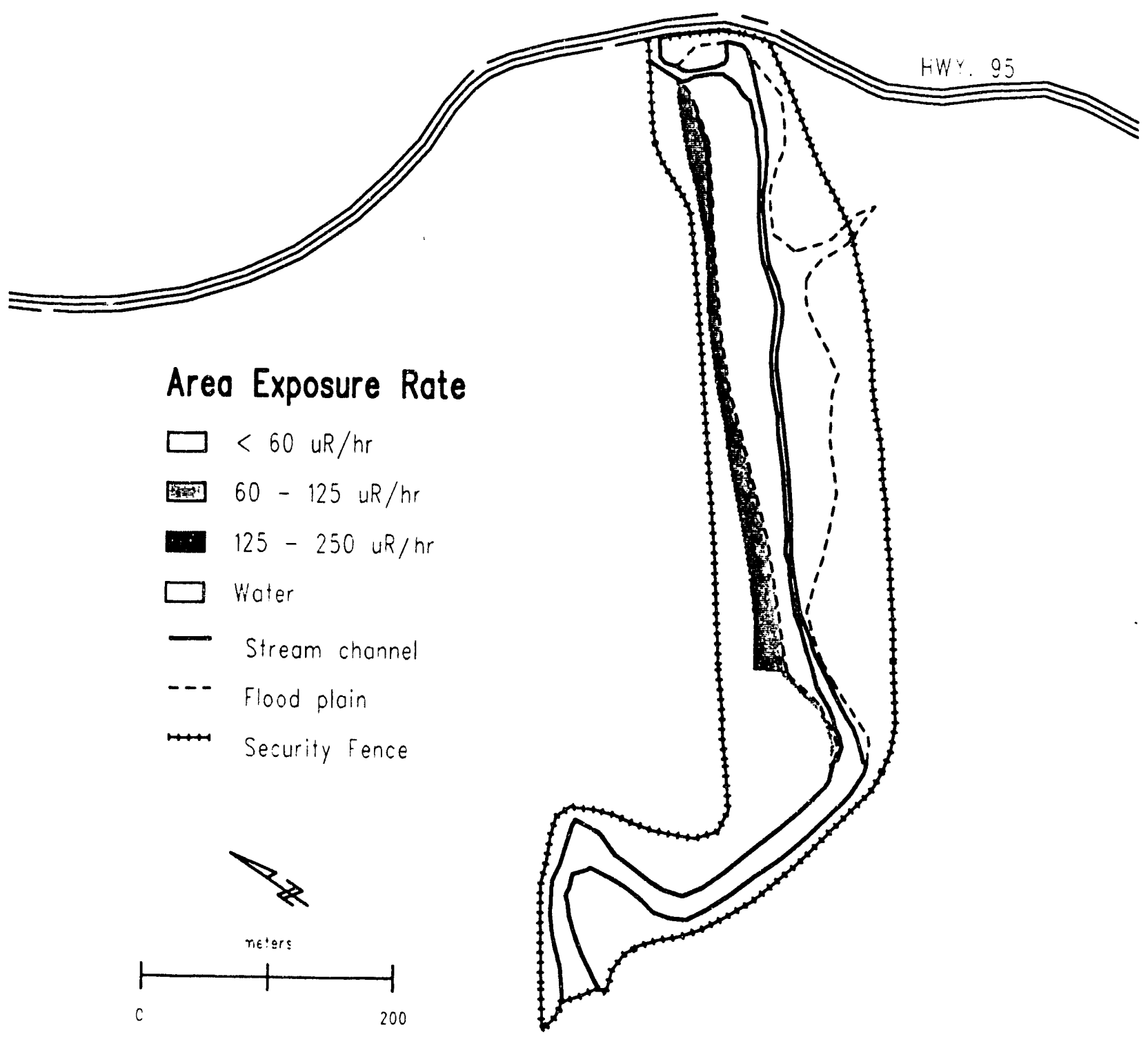

Fig. 1.11. Survey of gamma (primarily ${ }^{137} \mathrm{Cs}$ ) radiation exposure rates measured 1 meter above the ground surface when the water was at low-pool level. The shaded areas show the exposure rates on the north side from the personnel fence to the water line at full-pool level. 


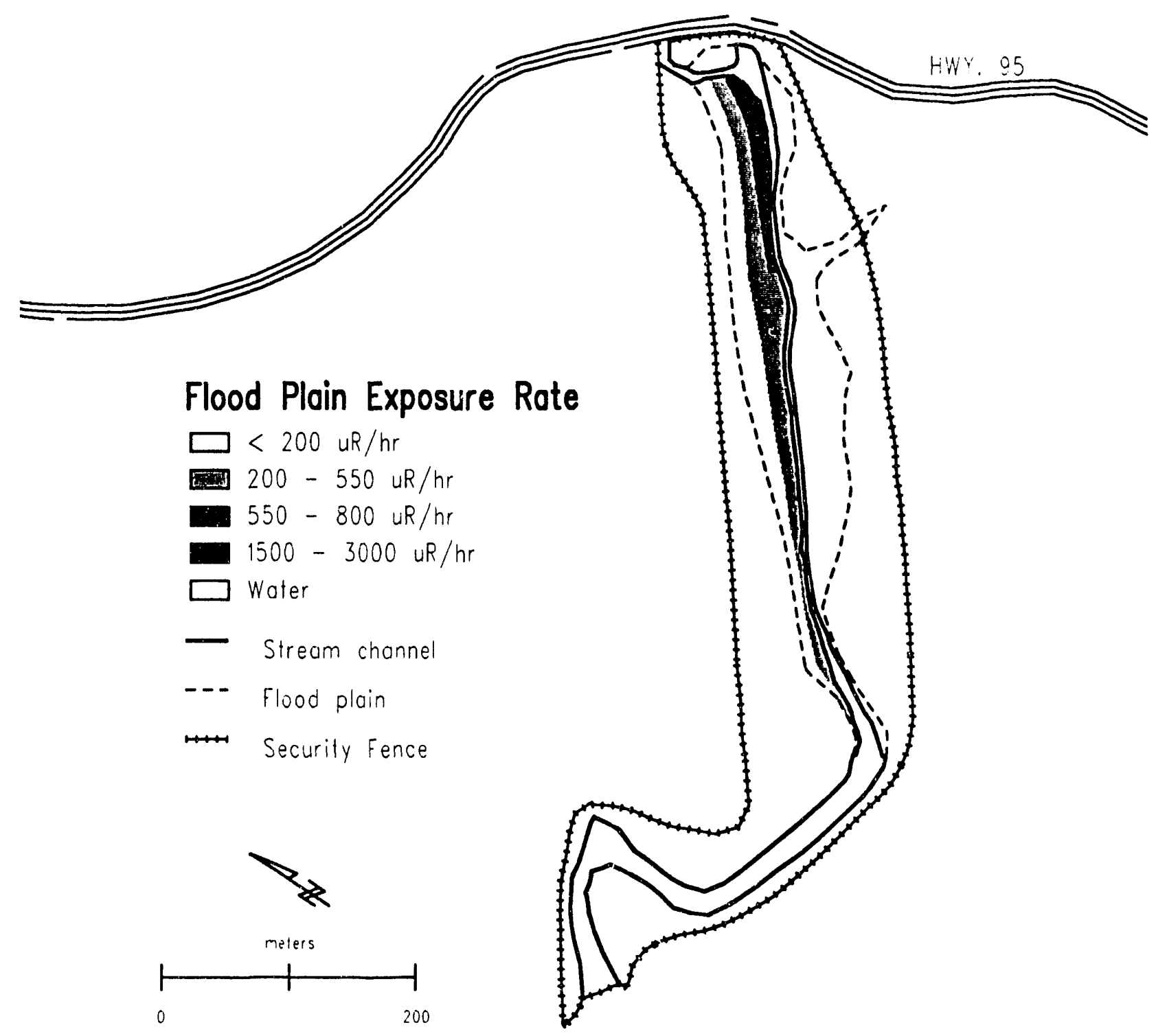

Fig. 1.12. Survey of gamma (primarily ${ }^{137} \mathrm{Cs}$ ) radiation exposure rates measured $1 \mathrm{~m}$ above the floodplain surface when the water was at low-pool level. The shaded areas show the exposure rates on the floodplain north of the stream channel. The maximum exposure rate was $3000 \mu \mathrm{R} / \mathrm{h}$. 


\section{SCREENING OF CONTAMINANTS IN THE WHITE OAK CREEK EMBAYMENT}

\subsection{INTRODUCTION}

A preliminary screening of contaminants in the off-site surface water environment (Hoffman et al. 1990) indicated that WOCE was an area of concern because of the potential for external exposure to ${ }^{137} \mathrm{Cs}$. The off-site screening analysis used historical data for WOCE. The current screening analysis of WOCE is based primarily on data collected from WOCE since the preliminary screening by Hoffman et al. (1990) was completed.

It is emphasized that the exposure pathways used in this screening analysis are entirely hypothetical. The embayment is surrounded by a security fence, and only authorized personnel are permitted entry; nevertheless, for the purpose of this contaminant screening analysis, it was assumed that the public has limited access to the area. A screening analysis based on ecological effects was not included in the present study because the embayment is a relatively small area and any ecological effects within its boundary are unlikely to have a significant impact on biota in the surrounding area.

In 1992, Clinch River RI data collected from WOCE were independently validated against EPA quality assurance criteria. This review showed that results for certain analytes in some samples were unacceptable and should not be used. Appendix summary tables for Clinch River RI data list only the validated results and qualifiers except for two notable instances. In the first case, tritium and ${ }^{90} \mathrm{Sr}$ results for water were rejected because of improper sample preservation; however, the results are within the range of ORNL radiological monitoring data collected over the same time period and are included in the summary table and in the contaminant screening analysis. In the second case, sediment grab samples analyzed for gamma-emitting radionuclides by the ORNL Health and Safety Research Division Measurement Application Development Laboratory were not validated because laboratory quality control data were not available. These nonvalidated csults were compared to historical data and/or results for co-located Clinch River RI samples tha: were validated. The results compared favorably and were considered reliable estimates of surface sediment concentrations. All nonvalidated results have a qualifier of "NOTV."

The validated results were within the ranges of the previous data; therefore, the human health screening analysis was not revised. Conclusions would not have changed by revising the screening analysis with the validated data.

\section{APPROACH}

Both conservative and nonconservative contaminant screening procedures, similar to those used by Hoffman et al. (1990), were used in this screening analysis. The conservative approach is highly unlikely to underestimate potential maximum exposures to individuals using the embayment but may substantially overestimate the majority of the actual exposures to individuals. The nonconservative approach provides a more realistic estimate of exposure and should not substantially cverestimate the maximum exposure to individuals. Under some circumstances, nonconservative screening could underestimate maximum exposures. In 
addition, calculations were made for a hypothetical intruder scenario-not for screening purposes but to determine a realistic level of risk to a fisherman who illegally enters and fishes in the embayr ient.

\section{SCREENING INDEXES}

The screening index for a carcinogen is an estimate of exposure to the contaminant via external exposure, ingestion, or inhalation multiplied by an EPA-approved or -suggested slope factor for radioactive and nonradioactive substances to indicate the potential lifetime risk of excess cancer (EPA 1990). The slope factor provides an estimate of the lifetime risk of additional cancer incidence per unit exposure.

The screening index for noncarcinogens is an estimate of the daily ingestion or inhalation of the contaminant divided by a "reference dose factor." The reference dose is an EPA-approved noncarcinogenic contaminant exposure level below which adverse effects should not occur.

To estimate the potential risk from all contaminants in a particular exposure pathway, the screening indexes are totalled among all contaminants in a pathway. Sumrnation is conducted separately for carcinogens and noncarcinogens. To estimate the potential risk from exposure to multiple pathways, the screening indexes are totalled acrnss rathways.

\section{PATHWAYS}

Because WOCE is surrounded by a personnel exclusion fence and the size of the area is relatively small, the number of exposure pathways considered ir: the present screening assessment is limited. Four pathways were considered for both conservative aid nonconservative screening: (1) exiernal exposure to shoreline sediments, (2) ingestion of sediments, (3) ingestion of fish, and (4) ingestion of water. The inhalation pathway was not considered in this analysis because it was of relatively minor consequence in the previous screening exercise (Hoffman ei al. i990).

\subsection{DATA}

The data represent measurements of contaminants in sediment, water, and fish. Appendixes A through $\mathrm{G}$ contain itemized data and data summaries from which the screening data were derived. All data are from samples collected in 1989 and 1990 except for the organic and inorganic contaminants in sediments. Because only one core sample collected in 1990 had been analyzed for organic and inorganic contaminants (Table 1 of Appendix C), data from TVA sediment cores (TVA 1986) (Appendix B) were included in the data base. Since that time, two additional sediment cores from the embayment were analyzed for organic contaminants (cores 553000 and 555000) and three for inorganic contaminants (cores $54100 \mathrm{~T}, 54300 \mathrm{~T}$, and $63500 \mathrm{~T}$ ) (Fig. 1.6). A comparison of the data from these cores (Table 2 of Appendix C) with the earlier data (Table 1 of Appendix C) is provided in Sects. 1.3.4 and 1.3.5 of this report. 
Thirty-one additional core samples (Fig. 1.6) were collected and analyzed for gamma-emitting radionuclides after core $9500 \mathrm{G}$ was collected in 1990 . Because of the large quantity of additional data contributed by these cores and the fact that concentrations of radionuclides found in the latest cores differ from those reported previously (Sect. 1.3.3), the human health screening analysis for radionuclides in sediment has been updated to include the new data.

The available data were divided into two data sets (Table 2.1) consisting of (1) contaminants for which at least one measurement for a contaminant was above the level of detection (detectable contaminants) and (2) contaminants for which all measurements were below the level of detection (nondetectable contaminants). Although values for contaminants detected at concentrations less than the contract-required quantitation were reported as estimates, these contaminants were included with the detectable contaminants. For conservative screening, the upper 95\% confidence limit of the arithmetic mean (EPA 1989) for each contamir int in both the detectable and nondetectable contaminants data sets was 'sed to represent the contaminant concentration. For nonconservative screening, the geometric mean of each contaminant in the detectable contaminants data set was used as the contaminant concentration. For the nondetectable contaminants data set, the upper $95 \%$ confidence limit of the arithmetic mean of the detection limits and the lowest detection limit that was available in the data base were used as the contaminant concentration for conservative and nonconservative screening, respectively (Table 2.1).

Table 21. Values used for contaminant concentrations in conservative and nonconservative screening and intruder scenarios

\begin{tabular}{lll}
\hline Data bas & Screening scenarios \\
\hline $\begin{array}{c}\text { Detectable } \\
\text { contaminants }\end{array}$ & $\begin{array}{l}\text { Upper } 95 \% \text { confidence limit } \\
\text { of the arithmetic mean } \\
\text { intruder }\end{array}$ & Geometric mean \\
$\begin{array}{c}\text { Nondetectable } \\
\text { contaminants }\end{array}$ & $\begin{array}{l}\text { Upper } 95 \% \text { confidence limit } \\
\text { of the arithmetic mean }\end{array}$ & $\begin{array}{l}\text { Lowest limit of detection for } \\
\text { the contaminant reported in } \\
\text { the data base }\end{array}$ \\
\hline
\end{tabular}

${ }^{a}$ The intruder scenario was not applied to the nondetectable contaminants data base.

\section{$\approx 6$ USAGE FACTORS}

The usage factors for conservative screening listed in Table 2.2 are from Hoffman et al. (1990). For nonconservative screening, usage factors were taken as one-tenth the value used for conservative screening (Table 2.2). Hoffman et al. (1990) used a 70-year lifetime exposure for radionuclides. Recently, EPA reconsidered the maximum lifetime exposure duration for an individual and now recommends using a lifetime exposure period of $350 \mathrm{~d} /$ year for 30 years (OSWER 1991). A 30-year lifetime exposure was used in the present radiological screening analysis. 
Table 2.2. Usage factors for conservative and nonconservative screening

\begin{tabular}{lcc}
\hline Exposure route & Conservative screening & Nonconservative screening \\
\hline Ingestion & & \\
Fish & $20 \mathrm{~g} / \mathrm{d}$ & $2 \mathrm{~g} / \mathrm{d}$ \\
Drinking water & $2 \mathrm{~L} / \mathrm{d}$ & $0.2 \mathrm{~L} / \mathrm{d}$ \\
$\quad$ Sediment ingestion & $0.1 \mathrm{~g} / \mathrm{d}$ & $0.01 \mathrm{~g} / \mathrm{d}$ \\
External exposure & & \\
$\quad$ Radioactive sediments & $1000 \mathrm{~h} /$ year & $100 \mathrm{~h} /$ year \\
\hline
\end{tabular}

\section{INTRUDER SCENARIO}

In addition to the conservative and nonconservative screening scenarios, calculations were made for an intruder scenario. This hypothetical scenario represents a more realistic situation that could occur under current conditions and provides a reasonable estimate of risk to a maximally exposed individual. The scenario selected was for a fisherman who illegally enters the embayment at the mouth of White Oak Creek and remains in the embayment for $4 \mathrm{~h}$ per incursion. The intruder enters the embayment 12 times each year for 10 years and each time catches enough fish for one meal of $500 \mathrm{~g}$. In this scenario, only two exposure pathways, external radiation from sediment and ingestion of fish, were considered.

\subsection{SCREENING CRITERIA}

According to EPA (Federal Register 1990c), a risk of $\geq 10^{-4}$ excess cancers for a lifetime exposure to carcinogens is considered an action level that requires immediate consideration for remedial action. Between $10^{-4}$ and $10^{-6}$ risk is an area of concern where negotiation on remedial action alternatives occurs and additional investigation is often required. Carcinogens having a risk below $10^{-6}$ are of less concern and can be assigned a lower priority for further investigation. The purpose of conservative screening is to identify contaminants that have a low priority for further investigation. In contrast, nonconservative screening is used to identify contaminants with high priority for either immediate consideration for remedial action or further study.

Screening criteria used in this report are summarized in Figs. 2.1 and 2.2. For conservative screening, carcinogens having screening indexes of $\leq 10^{-6}$ are of low priority for further consideration (Fig. 2.1). Carcinogens having screening indexes between $10^{-6}$ and $10^{-4}$ are of potentially low priority and require further investigation before either taking action or designating these contaminants as low priority. Carcinogens having screening indexes of $210^{-4}$ require further investigation before taking action.

For nonconservative screening, carcinogens having screening indexes of $210^{-4}$ are high priority contaminants requiring immediate consideration for remedial action (Fig. 2.1). Carcinogens with screening indexes between $10^{-4}$ and $10^{-6}$ are substances requiring further investigation before taking action (i.e., examination of the data base, checking parameter values, recalculating screening indexes, additional sampling, etc.). Because nonconservative 
screening employs parameter values that should not greatly overestimate maximum exposures to a contaminant, nonconservative screening is not used to identify contaminants with low priority for further consideration.

Figure 2.2 summarizes the screening criteria for noncarcinogens. For conservative screening of noncarcinogens, contaminants with screening indexes (exposure divided by a reference dose) of $\leq 0.1$ are of low priority for further consideration, and contaminants with screening indexes between 1.0 and 0.1 require further investigation before either taking action or designating them as low priority substances. Noncarcinogens with conservative screening indexes of $\geq 1.0$ require further investigation before taking action.

For nonconservative screening of noncarcinogens, contaminants with screening indexes of $\geq 1.0$ are high priority contaminants requiring immediate consideration for remedial action, and contaminants with screening indexes between 1.0 and 0.1 require further investigation before action is taken (Fig. 2.2). Screening indexes of $<0.1$ are not used to designate low priority for reasons similar to those previously stated for nonconservative screening of carcinogens. 


\section{Conservative Estimate of Exposure}

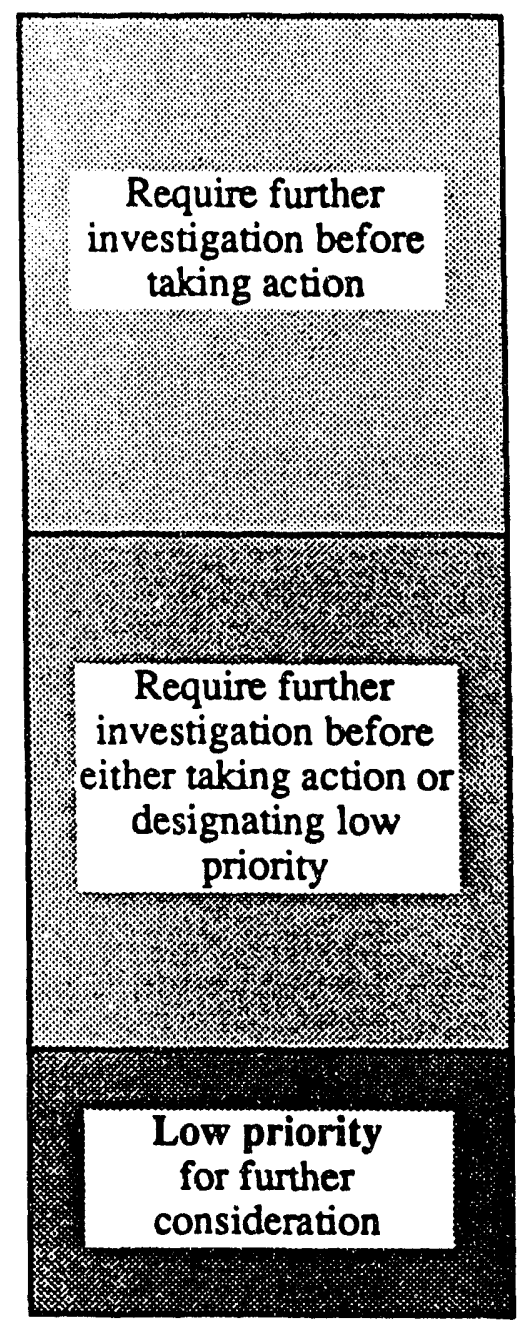

Nonconservative Estimate of Exposure

\section{SI}

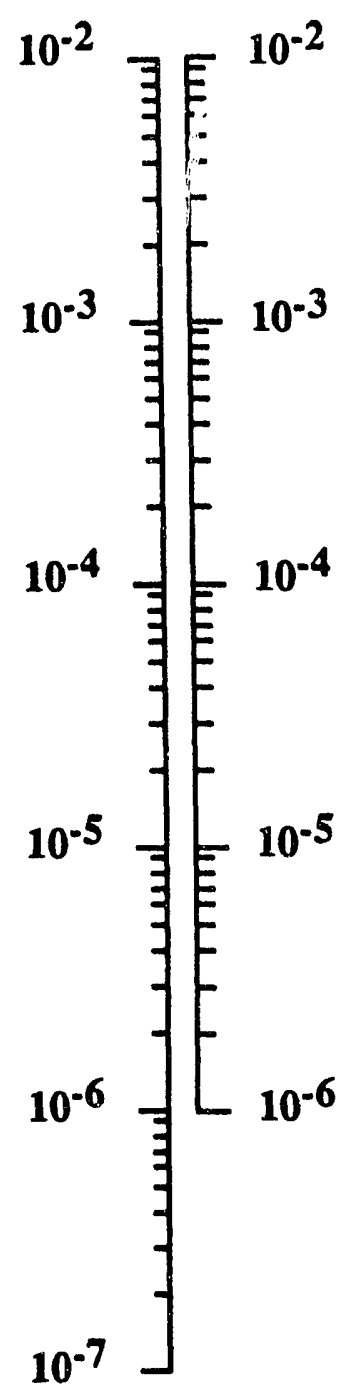

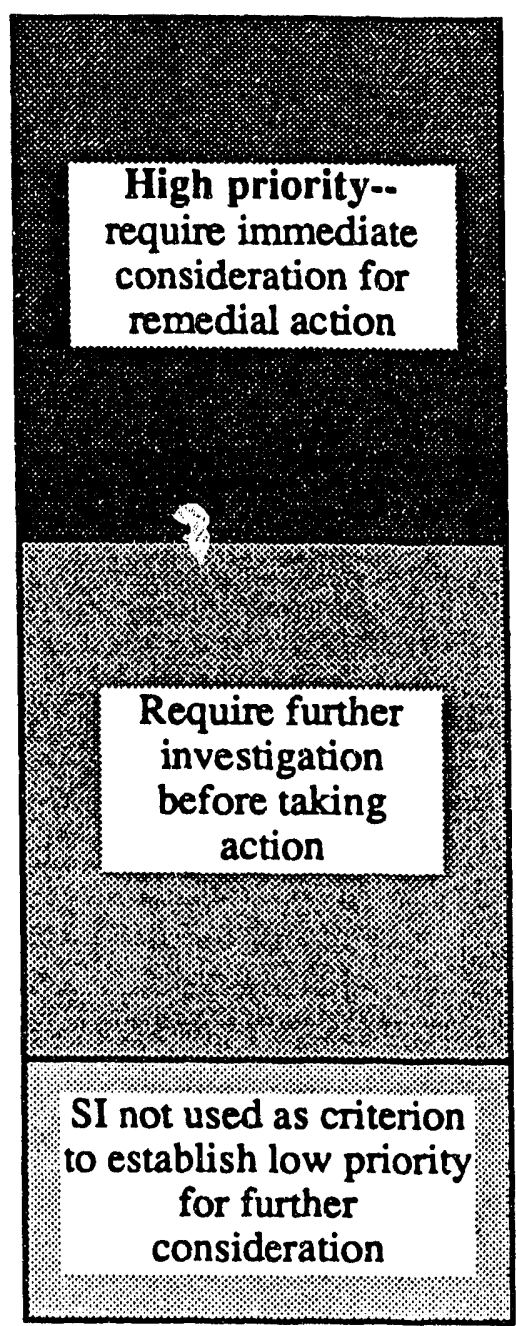

Screening index $(\mathrm{SI})=$ exposure multiplied by a lifetime cancer slope factor.

Fig. 21 Criteria for conservative and nonconservative screening of carcinogens. 

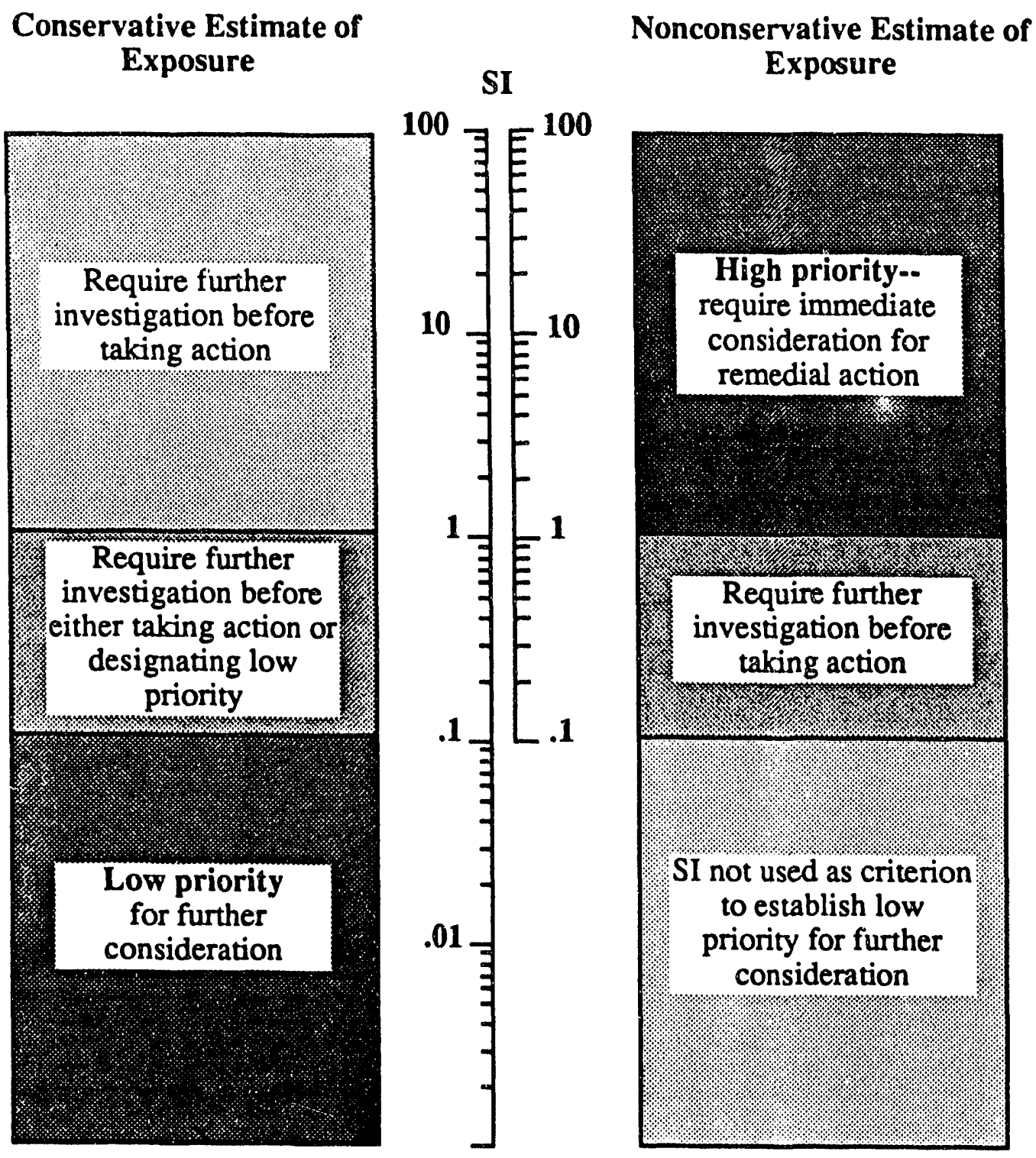

Screening index $(\mathrm{SI})=$ exposure divided by reference dose factor $(\mathrm{RfD})$.

Fig. 2.2 Criteria for conservative and nonconservative screening of noncarcinogens. 


\section{CONTAMINANT SCREENING RESULTS}

\subsection{DETECTABLE CONTAMINANTS}

Results of conservative and nonconservative screening for each contaminant which had at least one value above detection limits are given in Appendix $\mathrm{H}$ and Appendix I, respectively. Results of the screening for the intruder scenario are given in Appendix $J$.

\subsubsection{Conservative Screening}

\subsubsection{Carcinogens}

The purpose of conservative screening is to identify contaminants that can be assigned a low priority for further investigation. A summary of the screening indexes for conservative screening of carcinogens in the detectable contaminants data base is given in Table 3.1. The detectable contaminants data base includes only those contaminants with at least one value for a particular medium that was above the limits of detection. The screening indexes are summed by pathway (ingestion of fish, water, and sediment and external exposure to radiation) for each class of contaminant (organics, inorganics, and radionuclides). In Table 3.1, the screening indexes for all classes of contaminants and all exposure pathways are $\geq 10^{-6}$; therefore, no class of contaminant or exposure pathway can be designated as low priority for further consideration.

Complete results of the conservative screening of carcinogens with values above detection limits are given in Table 1 of Appendix $\mathrm{H}$. Individual contaminants are listed according to screening category in Table 3.2. One inorganic contaminant, one organic contaminant, and eight radionuclides in the sediment ingestion pathway were identified as low priority for further consideration. In addition, five radionuclides in the external exposure pathway and one in the water ingestion pathway also had screening indexes of $<10^{-6}$ and would be assigned to the same category. The remaining carcinogens in this data base had screening indexes of $>10^{-6}$ which placed them in a category requiring further investigation.

\subsubsection{Noncarcinogens}

A summary of the conservative screening indexes for classes of contaminants and exposure pathways for the noncarcinogens where at least one measurement was above detection limits is given in Table 3.3. All organics in the sediment and water ingestion pathways (screening indexes of <0.1) were identified as low priority for further consideration. Table 3.4 lists the individual contaminants that were assigned a low priority for further consideration. They are selenium, arsenic, and zinc in the fish ingestion pathway; arsenic, zinc, chromium, silver, cadmium, nickel, uranium, and beryllium in the sediment ingestion pathway; and zinc, cadmium, nickel, and mercury in the water ingestion pathway. Mercury in the fish and sediment ingestion pathways, chromium in the water ingestion pathway, and chlordane in the fish ingestion pathway have screening indexes between 0.1 and 1.0 and require further investigation before either taking action or designating these contaminants as low priority. Arsenic in the water ingestion pathway was the only contaminant that had a screening index of $>1.0$, which would require further investigation before taking action. The complete results of the conservative screening of the noncarcinogens in the data base of detected contaminants are given in Table 2 of Appendix $\mathrm{H}$. 
Table 3.1. Summary table for conservative screening of detected carcinogens

\begin{tabular}{|c|c|c|}
\hline Media & $\begin{array}{c}\text { Contaminant } \\
\text { type }\end{array}$ & $\begin{array}{c}\text { Sums of } \\
\text { carcinogen } \\
\text { screening indexes }\end{array}$ \\
\hline Fish & Inorganic & $7 \mathrm{E}-05^{a}$ \\
\hline Fish & Organic & $5 E-03$ \\
\hline Fish & Radionuclide & $9 E-05$ \\
\hline Fish & Total & $5 E-03$ \\
\hline External exposure & Radionuclide & $2 \mathrm{E}-01$ \\
\hline External exposure & External total & $2 \mathrm{E}-01$ \\
\hline Sediment & Inorganic & $4 \mathrm{E}-05$ \\
\hline Sediment & Organic & $5 E-05$ \\
\hline Sediment & Radionuclide & $3 E-04$ \\
\hline Sediment & Ingestion total & $4 \mathrm{E}-04$ \\
\hline Water & Inorganic & $3 E-03$ \\
\hline Water & Organic & $4 \mathrm{E}-04$ \\
\hline Water & Radionuclide & $1 \mathrm{E}-03$ \\
\hline Water & Total & $4 \mathrm{E}-03$ \\
\hline All & Grand total & $2 \mathrm{E}-01$ \\
\hline
\end{tabular}

${ }^{a} 7 \mathrm{E}-05=7 \times 10^{-5}$ 
Table 3.2 Carcinogens assigned to different screening categorics by conservative screening of data base where at least one value or each contaminant was above detection limits

\begin{tabular}{|c|c|c|}
\hline Contaminant type & Contaminant & Exposure pathway \\
\hline \multicolumn{3}{|c|}{$\begin{array}{l}\text { Low priority for further consideration } \\
\text { Screening indexes }<10^{-6}\end{array}$} \\
\hline Inorganic & Uranium & Sediment ingestion \\
\hline Organic & Bis(2-ethylhexyl)phthalate & Sediment ingestion \\
\hline Radionuclide & $\begin{array}{l}{ }^{238} \mathrm{Pu} \\
{ }^{239} \mathrm{Pu} \\
{ }^{239} \mathrm{Pu} \\
{ }^{234} \mathrm{U} \\
{ }^{238} \mathrm{U} \\
{ }^{60} \mathrm{Co} \\
{ }^{235} \mathrm{U} \\
{ }^{152} \mathrm{Eu} \\
{ }^{154} \mathrm{Eu} \\
{ }^{239} \mathrm{Pu} \\
{ }^{235} \mathrm{U} \\
{ }^{238} \mathrm{Pu} \\
{ }^{234} \mathrm{U} \\
{ }^{238} \mathrm{U}\end{array}$ & $\begin{array}{l}\text { Water ingestion } \\
\text { Sediment ingestion } \\
\text { Sediment ingestion } \\
\text { Sediment ingestion } \\
\text { Sediment ingestion } \\
\text { Sediment ingestion } \\
\text { Sediment ingestion } \\
\text { Sediment ingestion } \\
\text { Sediment ingestion } \\
\text { External exposure } \\
\text { External exposure } \\
\text { External exposure } \\
\text { External exposure } \\
\text { External exposure }\end{array}$ \\
\hline \multicolumn{3}{|c|}{$\begin{array}{l}\text { Require further investigation before taking action } \\
\text { or designating as low priority } \\
\text { Screening indexes } 10^{-6} \text { to } 10^{-4}\end{array}$} \\
\hline Inorganic & $\begin{array}{l}\text { Arsenic } \\
\text { Arsenic } \\
\text { Beryllium }\end{array}$ & $\begin{array}{l}\text { Fish ingestion } \\
\text { Sediment ingestion } \\
\text { Sediment ingestion }\end{array}$ \\
\hline Organic & $\begin{array}{l}\text { Chlordane } \\
4,4^{\prime} \text {-DDD } \\
\text { Aroclor-1254 } \\
\text { Aroclor-1260 } \\
\text { Trichloroethylene } \\
\text { Chloroform }\end{array}$ & $\begin{array}{l}\text { Fish ingestion } \\
\text { Fish ingestion } \\
\text { Sediment ingestion } \\
\text { Sediment ingestion } \\
\text { Water ingestion } \\
\text { Water ingestion }\end{array}$ \\
\hline Radionuclide & $\begin{array}{l}{ }^{137} \mathrm{Cs} \\
{ }^{91} \mathrm{Sr} \\
{ }^{60} \mathrm{Co} \\
{ }^{244} \mathrm{Cm} \\
{ }^{241} \mathrm{Am} \\
{ }^{228} \mathrm{Pu} \\
{ }^{90} \mathrm{Sr} \\
{ }^{241} \mathrm{Am}\end{array}$ & $\begin{array}{l}\text { Fish ingestion } \\
\text { Fish ingestion } \\
\text { Water iizestion } \\
\text { Water ingestion } \\
\text { Water ingestion } \\
\text { Water ingestion } \\
\text { Sediment ingestion } \\
\text { External exposure }\end{array}$ \\
\hline
\end{tabular}


Table 3.2 (continued)

\begin{tabular}{lll}
\hline \multicolumn{1}{c}{ Contaminant type } & \multicolumn{1}{c}{ Contaminant } & \multicolumn{1}{c}{ Exposure pathway } \\
\hline & Require further investigation before taking action \\
& \multicolumn{2}{c}{ Screening indexes $\geq 10^{-1}$} \\
Inorganic & Arsenic & Water ingestion ${ }^{a}$ \\
Organic & Aroclor-1254 & Fish ingestion \\
& Aroclor-1260 & Fish ingestion \\
& PCBs total & Water ingestion \\
Radionuclide & ${ }^{137} \mathrm{Cs}$ & External exposure \\
& ${ }^{137} \mathrm{Cs}$ & Sediment ingestion \\
& ${ }^{137} \mathrm{Cs}$ & Water ingestion \\
& ${ }^{60} \mathrm{Co}$ & External exposure \\
& ${ }^{3} \mathrm{H}$ & Water ingestion \\
& ${ }^{90} \mathrm{Sr}$ & Water ingestion \\
& ${ }^{152} \mathrm{Eu}$ & External exposure \\
& ${ }^{152} \mathrm{Eu}$ & External exposure \\
\hline
\end{tabular}

${ }^{a}$ Potential artifact

Table 3.3. Summary table for conservative screening of detected noncarcinogens

\begin{tabular}{|c|c|c|}
\hline Media & $\begin{array}{c}\text { Contaminant } \\
\text { type }\end{array}$ & $\begin{array}{c}\text { Sums of } \\
\text { noncarcinogen } \\
\text { screening indexes }\end{array}$ \\
\hline Fish & Inorganic & $3 E-01$ \\
\hline Fish & Organic & $3 \mathrm{E}-01$ \\
\hline Fish & Total & $6 E-01$ \\
\hline Sediment & Inorganic & $6 \mathrm{E}-01$ \\
\hline Sediment & Organic & $8 E-05$ \\
\hline Sediment & Total & $6 \mathrm{E}-01$ \\
\hline Water & Inorganic & $2 \mathrm{E}+00$ \\
\hline Water & Organic & $2 \mathrm{E}-02$ \\
\hline Water & Total & $2 E+\infty 0$ \\
\hline All & Grand total & $3 E+00$ \\
\hline
\end{tabular}


Table 3.4. Noncarcinogens assigned to different screening categories by conservative screening of data base where at least one value for each contaminant was above detection limits

\begin{tabular}{|c|c|c|}
\hline Contaminant type & Contaminant & Exposure pathway \\
\hline \multicolumn{3}{|c|}{$\begin{array}{l}\text { Low priority for further consideration } \\
\text { Screening indexes }<0.1\end{array}$} \\
\hline Inorganic & $\begin{array}{l}\text { Selenium } \\
\text { Arsenic } \\
\text { Arsenic } \\
\text { Zinc } \\
\text { 7inc } \\
\text { Zinc } \\
\text { Chromium } \\
\text { Silver } \\
\text { Cadmium } \\
\text { Cadmium } \\
\text { Nickel } \\
\text { Nickel } \\
\text { Uranium } \\
\text { Beryllium } \\
\text { Mercury }\end{array}$ & $\begin{array}{l}\text { Fish ingestion } \\
\text { Fish ingestion } \\
\text { Sediment ingestion } \\
\text { Fish ingestion } \\
\text { Water ingestion } \\
\text { Sediment ingestion } \\
\text { Sediment ingestion } \\
\text { Sediment ingestion } \\
\text { Sediment ingestion } \\
\text { Water ingestion } \\
\text { Sediment ingestion } \\
\text { Water ingestion } \\
\text { Sediment ingestion } \\
\text { Sediment ingestion } \\
\text { Water ingestion }\end{array}$ \\
\hline Organic & $\begin{array}{l}\text { Bis(2-ethylhexyl)phthalate } \\
\text { Diethylphthalate } \\
\text { Chloroform }\end{array}$ & $\begin{array}{l}\text { Sediment ingestion } \\
\text { Sediment ingestion } \\
\text { Water ingestion }\end{array}$ \\
\hline \multicolumn{3}{|c|}{$\begin{array}{c}\text { Require further investigation before taking action } \\
\text { or designating as low prionity } \\
\text { Screening indexes } 0.1 \text { to } 1.0\end{array}$} \\
\hline Inorganic & $\begin{array}{l}\text { Mercury } \\
\text { Mercury } \\
\text { Chromium }\end{array}$ & $\begin{array}{l}\text { Fish ingestion } \\
\text { Sediment ingestion } \\
\text { Water ingestion }\end{array}$ \\
\hline Organic & Chlordane & Fish ingestion \\
\hline \multicolumn{3}{|c|}{$\begin{array}{l}\text { Require further investigation before taking action } \\
\text { Screening indexes } \geq 1.0\end{array}$} \\
\hline Inorganic & Arsenic & Water ingestion \\
\hline
\end{tabular}

\subsubsection{Nonconservative Screening}

\subsubsection{Carcinogens}

The purpose of nonconservative screening is to identify contaminants with a high priority for immediate consideration for remedial action. Summaries of the screening indexes for the different classes of carcinogens and exposure pathways are given in Table 3.5. These indexes were calculated using the data set where each contaminant had at least one value above the limits of detection. Classes of carcinogens identified by nonconservative screening as having screening indexes of $>10^{-4}$ are radionuclides in the external exposure pathway, organics in the fish ingestion pathway, and inorganics and radionuclides in the water ingestion pathway. 
Table 3.5. Summary table for nonconservative scrcening of detected carcinogens

\begin{tabular}{lcc}
\hline Media & $\begin{array}{c}\text { Contaminant } \\
\text { type }\end{array}$ & $\begin{array}{c}\text { Sums of } \\
\text { carcinogen } \\
\text { screening indexes }\end{array}$ \\
\hline Fish & $\begin{array}{c}\text { Inorganic } \\
\text { Fish }\end{array}$ & $\begin{array}{c}4 \mathrm{E}-06 \\
\text { Radionuclide }\end{array}$ \\
Fish & Total & $4 \mathrm{E}-04$ \\
\hline Fish & & $2 \mathrm{E}-04$ \\
\hline External exposure & Radionuclide & \\
\hline External exposure & External total & $3 \mathrm{E}-03$ \\
\hline Sediment & & $3 \mathrm{E}-03$ \\
Sediment & Inorganic & $3 \mathrm{E}-06$ \\
Sediment & Organic & $8 \mathrm{E}-07$ \\
\hline Sediment & Radionuclide & $9 \mathrm{E}-06$ \\
\hline Water & Ingestion total & $1 \mathrm{E}-05$ \\
Water & & \\
Water & Inorganic & $2 \mathrm{E}-04$ \\
\hline Water & Organic & $2 \mathrm{E}-05$ \\
\hline \hline All & Radionuclide & TE-04 \\
\hline
\end{tabular}

Individual carcinogens designated as high priority (screening indexes of $>10^{-4}$ ) and those requiring further investigation (screening indexes from $10^{-4}$ to $10^{-6}$ ) are listed in Table 3.6 according to contaminant type and exposure pathway. Arsenic, $\mathrm{PCBs},{ }^{60} \mathrm{Co}$, and ${ }^{137} \mathrm{Cs}$ were identified as carcinogens in WOCE which are high priority and require immediate consideration for remedial action. Cesium-137 had the highest screening index $\left(3 \times 10^{-3}\right)$ and was the major radionuclide contributing to the external exposure pathway. Arsenic in water (Table 1 of Appendix I) may be an artifact because only 2 of the 24 samples analyzed were above the level of detection. Although the sum of the screening indexes for radionuclides in the water ingestion pathway exceeded $10^{-4}$ (Table 3.5 ), the individual radionuclides $\left({ }^{3} \mathrm{H},{ }^{137} \mathrm{Cs}\right.$, and ${ }^{90} \mathrm{Sr}$ ) had screening indexes of $<10^{-4}$ (Table 1 of Appendix $\mathrm{I}$ ) and are identified in Table 3.6 as requiring further investigation before taking action.

\subsubsection{Noncarcinogens}

A summary of the screening indexes for each class of noncarcinogen and each exposure pathway is given in Table 3.7. None of the contaminants was identified by nonconservative 
Table 3.6. Carcinogens assigned to different screening categories by nonconservative screening of data base where at least one value for each contaminant was above detection limits

\begin{tabular}{|c|c|c|}
\hline Contaminant type & Contaminant & Exposure pathway \\
\hline \multicolumn{3}{|c|}{$\begin{array}{l}\text { High priority-require immediate consideration for remedial action } \\
\text { Screening indexes } \geq 10^{-1}\end{array}$} \\
\hline Inorganic & Arsenic & water ingestion ${ }^{a}$ \\
\hline Organic & Aroclor-1254 & fish ingestion \\
\hline Radionuclide & $\begin{array}{l}{ }^{137} \mathrm{Cs} \\
{ }^{60} \mathrm{Co}\end{array}$ & $\begin{array}{l}\text { external exposure } \\
\text { external exposure }\end{array}$ \\
\hline \multicolumn{3}{|c|}{$\begin{array}{l}\text { Require further investigation before taking action } \\
\text { Screening indexes } 10^{-1} \text { to } 10^{-6}\end{array}$} \\
\hline Inorganic & $\begin{array}{l}\text { Arsenic } \\
\text { Arsenic } \\
\text { Beryllium }\end{array}$ & $\begin{array}{l}\text { fish ingestion } \\
\text { sedimient ingestion } \\
\text { sediment ingestion }\end{array}$ \\
\hline Organic & $\begin{array}{l}\text { Aroclor }-1260 \\
\text { Chlordane } \\
\text { PCBs total }\end{array}$ & $\begin{array}{l}\text { fish ingestion } \\
\text { fish ingestion } \\
\text { water ingestion }\end{array}$ \\
\hline Radionuclide & $\begin{array}{l}{ }^{137} \mathrm{Cs} \\
{ }^{137} \mathrm{Cs} \\
{ }^{137} \mathrm{Cs} \\
{ }^{3} \mathrm{H} \\
{ }^{90} \mathrm{Sr} \\
{ }^{90} \mathrm{Sr} \\
{ }^{152} \mathrm{Eu}\end{array}$ & $\begin{array}{l}\text { fish ingestion } \\
\text { sediment ingestion } \\
\text { water ingestion } \\
\text { water ingestion } \\
\text { water ingestion } \\
\text { sediment ingestion } \\
\text { external exposure }\end{array}$ \\
\hline
\end{tabular}

${ }^{a}$ Potential artifact

screening as high priority, requiring immediate consideration for remedial action. Only inorganics in the water ingestion pathway had a screening index of $>0.1$, which would require further investigation. Table 3.8 shows arsenic in the water ingestion pathway as the only contaminant requiring further investigation before taking action; however, this result may be an artifact, because only 2 of 24 samples (Table 2 of Appendix I) analyzed were above the limits of detection. Complete results of the nonconservative screening of noncarcinogens are given in Table 2 of Appendix I.

\subsubsection{Intruder Scenario}

\subsubsection{Carcinogens}

The purpose of the intruder scenario is to represent a potential, although illegal, use of the embayment under current conditions. The assumptions of this scenario appear to be reasonable but are applicable to very few, if any, individuals because of security safeguards. However, these assumptions are generally less conservative than those used for nonconservative screening. Only two pathways, fish ingestion and external exposure, and the data with contaminant values above detection limits are considered in this scenario. A 
summary of the results of the screening for carcinogens based on the intruder scenario is given in Table 3.9. Screening indexes for the fish ingestion pathway and radionuclides in the external exposure pathway were $>10^{-4}$. For the fish ingestion pathway, organics with a screening index of $2 \times 10^{-4}$ were the primary carcinogens of concern. The PCBs (Aroclors) were the main contributor to the high screening index (Table 1 of Appendix J). The external

Table 3.7. Summary table for nonconservative screening of detected noncarcinogens

\begin{tabular}{lcc}
\hline Media & $\begin{array}{c}\text { Contaminant } \\
\text { type }\end{array}$ & $\begin{array}{c}\text { Sums of } \\
\text { noncarcinogen } \\
\text { screening indexes }\end{array}$ \\
\hline $\begin{array}{l}\text { Fish } \\
\text { Fish }\end{array}$ & $\begin{array}{c}\text { Inorganic } \\
\text { Organic }\end{array}$ & $\begin{array}{c}2 \mathrm{E}-02 \\
2 \mathrm{E}-02\end{array}$ \\
\hline Fish & Total & $4 \mathrm{E}-02$ \\
\hline Sediment & Inorganic & $1 \mathrm{E}-02$ \\
Sediment & Organic & $5 \mathrm{E}-06$ \\
\hline Sediment & Total & $1 \mathrm{E}-02$ \\
\hline Water & Inorganic & $1 \mathrm{E}-01$ \\
Water & Organic & $8 \mathrm{E}-04$ \\
\hline Water & Total & $1 \mathrm{E}-01$ \\
\hline \hline All & Grand total & $2 \mathrm{E}-01$
\end{tabular}

Table 3.8. Noncarcinogens assigned to different screening categories by nonconservative screening of data base where at least one value for each contaminant was above detection limits

\begin{tabular}{ccc}
\hline Contaminant type & Contaminant & Exposure pathway \\
\hline High priority - require immediate consideration for remedial action \\
Screening indexes $\geq 1.0$ \\
None \\
\\
Require further investigation before taking action \\
Screening indexes 0.1 to 1.0 & Water ingestion \\
Inorganic & Arsenic &
\end{tabular}


Table 3.9. Summary table of intruder scenario screening indexes for detected carcinogens

\begin{tabular}{lcc}
\hline Media & $\begin{array}{c}\text { Contaminant } \\
\text { type }\end{array}$ & $\begin{array}{c}\text { Sums of } \\
\text { carcinogen } \\
\text { screening indexes }\end{array}$ \\
\hline Fish & $\begin{array}{c}\text { Inorganis } \\
\text { Organic } \\
\text { Fish }\end{array}$ & $\begin{array}{c}5 \mathrm{E}-06 \\
2 \mathrm{E}-04 \\
5 \mathrm{E}-06\end{array}$ \\
\hline Fish & Radionuclide & $2 \mathrm{E}-04$ \\
\hline Exh & Ingestion total & $2 \mathrm{E}-04$ \\
\hline External exposure & Radionuclide & $2 \mathrm{E}-04$ \\
\hline \hline All & External total & $4 \mathrm{E}-04$
\end{tabular}

exposure pathway was dominated by ${ }^{137} \mathrm{Cs}$ with a screening index of $5 \times 10^{-4}$ (Table 1 of Appendix $\mathrm{J}$ ). In the nonconservative screening analysis, external exposure to ${ }^{137} \mathrm{Cs}$ in sediment was the primary contaminant of concern with a screening index of $3 \times 10^{-3}$ (Table 1 of Appendix I). Although the exposure time in the intruder scenario ( $48 \mathrm{~h} /$ year for 10 years) was less than the exposure time in the nonconservative scenario, ${ }^{137} \mathrm{Cs}$ in the intruder external exposure pathway was still the primary contaminant of concern (screening index of $5 \times 10^{-4}$ ). However, because fish consumption was increased in the intruder scenario, ingestion of PCBs (screening index of $1.8 \times 10^{-4}$ ) was of almost equal importance to the external exposure.

\subsubsection{Noncarcinogens}

A summary of the screening indexes for the noncarcinogens in the intruder scenario is shown in Table 3.10. Only the fish ingestion pathway is applicable for noncarcinogens in the intruder scenario. Both organics and inorganics in the fish ingestion pathway had screening indexes of $>0.1$. Mercury and chlordane were the inorganic and organic contaminants, respectively, of concern (Table 2 of Appendix J).

Table 3.10. Summary table of intruder scenario screening indexes for detected noncarcinogens

\begin{tabular}{lcc}
\hline Media & $\begin{array}{c}\text { Contaminant } \\
\text { type }\end{array}$ & $\begin{array}{c}\text { Sums of } \\
\text { noncarcinogen } \\
\text { screening indexes }\end{array}$ \\
\hline Fish & Inorganic & $2 \mathrm{E}-01$ \\
Fish & Organic & $2 \mathrm{E}-01$ \\
\hline Fish & Total & $3 \mathrm{E}-01$ \\
\hline
\end{tabular}




\subsection{NONDETECTABLE CONTAMINANTS}

The nondetectable contaminants data base contains approximately three times as many contaminants as the detectable contaminants data base. Some contaminants are included in both data bases because the contaminant was present in detectable quantities in one medium and not in another. The screening would not be complete unless the nondetectable contaminant data are included in the analysis; however, caution should be exercised in interpreting the results.

\subsubsection{Conservative Screening}

The main purpose of conservative screening is to identify contaminants with a low priority for further consideration. Because the values for nondetectable contaminants are based on detection limits, contaminant concentrations that were used in the screening are greater than concentrations actually present in the samples. This bias can significantly increase the conservatism of the screening; therefore, the number of contaminants identified as low priority will probably be small.

\subsubsection{Carcinogens}

Conservative screening of the nondetectable contaminants data base for carcinogens showed that nine organics in the sediment ingestion pathway and one each in the fish and water ingestion pathways could be assigned a low priority for further consideration. All the remaining carcinogens had screening indexes of $\geq 10^{-6}$ in one or more exposure pathways. Complete results of the conservative screening for the nondetectable contaminants data base are given in Table 1 of Appendix $\mathrm{K}$. Of the 46 organic carcinogens below the level of detection, 11 had screening indexes between $10^{-4}$ and $10^{-6}$ (Table 1 of Appendix $\mathrm{K}$ ) for all pathways considered, thereby requiring further investigation before action is taken or the contaminants are designated as low priority. Beryllium, ${ }^{235} \mathrm{U}$, and ${ }^{60} \mathrm{Co}$ in the fish ingestion pathway also had screening indexes between $10^{-4}$ and $10^{-6}$ and would be assigned to the same category.

\subsubsection{Noncarcinogens}

For noncarcinogens in the nondetectable contaminants data base, all metals except thallium and antimony had conservative screening indexes of $\leq 0.1$ for all pathways considered and can be designated as low priority for further consideration (Table 2 of Appendix K). The high screening indexes for both thallium and antimony are based on only one water sample and therefore may be artifacts. Of the $\mathbf{4 6}$ organic noncarcinogens included in the screening analysis, all but 11 of these had screening indexes of $<0.1$ for all pathways considered and can be designated as low priority for further investigation. Two contaminants had screening indexes of $>1.0$ and would require further investigation before action is taken.

\subsection{Nonconservative Screening}

The results of nonconservative screening of the nondetectable contaminants are used to identify contaminants that have a high priority for either improving detection limits or determining from source-term data that releases from White Oak Lake have been in only extremely small quantities, if at all. Results of the nonconservative screening for the nondetectable contaminants data base are given in Appendix $\mathrm{L}$. 


\subsection{Carcinogens}

Seventeen organics in the nondetectable contaminants data base had nonconservative screening indexes of $\geq 10^{-4}$ (Table 1 of Appendix L) for at least one pathway, which identifies them as high priority for immediate consideration for further investigation either to improve limits of detection or to estimate concentrations from source-term data.

\subsubsection{Noncarcinogens}

Thallium in water was the only noncarcinogen with a screening index high enough (0.1) (Table 2 of Appendix L) to warrant further investigation as a result of nonconservative screening. However, this value is a potential artifact because only one water sample was analyzed.

\subsection{SPECIAL CASE LEAD}

Although an action level for lead of $0.015 \mathrm{mg} / \mathrm{L}$ has been adopted by EPA (EPA 1991), specific toxicity values are not available. Therefore, an EPA uptake/biokinetic model designed to a target population of children ( $0-6$ years old) was used to evaluate the risk posed by lead in WOCE. Results obtained using this model indicate that the concentrations of lead in water and sediment would not present a problem. This result is based on a hypothetical scenario because the embayment is a fenced area where the public is not allowed.

\subsection{NONCLASSIFIED CONTAMINANTS}

At the time this report was prepared, no reference dose or slope factors were available for the contaminants listed below. The four inorganics identified here were present in detectable quantities in either sediment, water, and/or fish collected from WOCE. None of the organics had concentrations that were above detection limits in any samples taken. The potential toxicity and/or cancer potency of these contaminants must be evaluated before their screening indexes can be calculated.

\section{- Organics}
1,3-Dichlorobenzene
2-Chloronaphthalene
2-Nitrophenol
4-Bromophenyl-phenylether
4-Chlorophenyl-phenylether
4-Nitrophenol
Bis(2-chloroethoxy)methane
Delta-BHC
Di-n-octylphthalate
Endosulfan sulfate
Endrin ketone

\section{- Inorganics}
Aluminum
Copper
Lead
Zirconium 


\section{CONCLUSIONS}

In September 1990, the finding of relatively high concentrations of ${ }^{137} \mathrm{Cs}\left[10^{6} \mathrm{~Bq} / \mathrm{kg}\right.$ dry wt $\left(>10^{4} \mathrm{pCi} / \mathrm{g}\right.$ dry $\left.\left.\mathrm{wt}\right)\right]$ in surface sediments at the mouth of WOCE resulted in the filing of an occurrence report and the notification of regulatory agencies. Available evidence indicates that large amounts of ${ }^{137} \mathrm{Cs}$-contaminated sediment were released from White Oak Lake into the embayment in the mid-1950s and that they have been eroded and transported downstream. Analyses of additional sediment cores collected after July 1990 show that sediment in the depositional zone of the old stream channel is contaminated with ${ }^{137} \mathrm{Cs}$ to a depth of $\sim 1 \mathrm{~m}$. This contaminated sediment could eventually be eroded and transported into the Clinch River.

A conservative and nonconservative screening analysis was conducted on fish, water, and sediment data collected in 1990 and 1991 from White Oak Creek embayment to identify contaminants that might pose a threat to human health. The nonconservative screening of detectable carcinogens identified arsenic in water, Aroclor-1254 (a PCB) in fish, and ${ }^{60} \mathrm{Co}$ and ${ }^{137} \mathrm{Cs}$ in sediment as high-priority contaminants requiring immediate consideration. Arsenic in water is possibly an artifact because only 2 of 24 samples analyzed had concentrations above the limits of detection. Nonconservative screening did not identify any noncarcinogens as high priority contaminants requiring immediate attention. Conservative screening of carcinogens identified ten carcinogens in the sediment ingestion pathway, one in the water ingestion pathway, and five in the external exposure pathway that could be designated as low priority for further study. Ten inorganic and three organic noncarcinogens were identified by conservative screening as low priority for further consideration.

Approximately two-thirds of the contaminants had concentrations that were below the limits of detection. Results of the screening of these nondetectable contaminants must be viewed with caution because the values used in the screening analysis are based on the detection limits. Using detection limits for concentrations increases the conservatism of the screening results. For this reason, conservative screening of nondetectable contaminants identified only a few contaminants as low priority for further consideration. Nonconservative screening of the nondetectable contaminants is useful in identifying contaminants that have a high priority for improving their detection limits. Sixteen organic carcinogens were identified as high priority for either improving detection limits or using source-term data to verify the presence of these contaminants.

Other assumptions (an intruder scenario) were used to evaluate the risk to a maximally exposed individual under current conditions. An individual (assumed to be an illegal intruder with intermittent visits over a period of 10 years) using the embayment for fishing purposes would be exposed to a potential lifetime risk of $>10^{-4}$ excess cancers from external exposure to ${ }^{137} \mathrm{Cs}$ and ingestion of PCBs in fish.

Radiological data from sediment samples were used to estimate inventories of radionuclides contained in the embayment sediment. Cesium-137 is the dominant radionuclide, and the estimated inventory ranges from 6.6 to $11.8 \mathrm{Ci}$, depending on the method of calculation. The second highest inventory is for ${ }^{90} \mathrm{Sr}$, which has an estimated $0.2 \mathrm{Ci}$ in the sediment. Other radionuclides are present but occur in much lower quantities. 
A walk-over radiation survey identified an area in the upper embayment with a relatively high external exposure rate $\left(3 \mathrm{mRh}^{-1}\right)$, which indicates that the ${ }^{137} \mathrm{Cs}$ inventory may be underestimated. Additional samples are required to reduce the uncertainty associated with the estimated inventory in the upper embayment.

As a result of the discovery of relatively high levels of contamination in the surface sediments in the lower portion of WOCE and the subsequent site characterization efforts described in this report, DOE, acting through Energy Systems, conducted a time-critical removal action (led and funded by DOE) at WOCE pursuant to the Comprehensive ENvironmental Response, Compensation, and Liability Act (CERCLA) as amended by the Superfund Amendments and Reauthorization Act and provisions of the latest version of the National Contingency Plan, 40 CFR Part 300, March 1980. The time-critical CERCLA removal action specifically consisted of design and construction of a sediment-retention structure across the mouth of WOCE to prevent off-site migration of contaminated sediments into the CLinch River. 


\section{REFERENCES}

Abee, H. H. 1953. Radioactivity in the Mud of White Oak Lake. ORNL-1580. Oak Ridge National Laboratory, Oak Ridge, Tennessee.

Boyle, J. W. et al. 1982. Environmental Analysis of the Operation of Oak Ridge National Laboratory ( $X$-10 Site), ORNL-5870, Oak Ridge National Laboratory, Oak Ridge, Tennessee.

Cerling, T. E., and B. P. Spalding. 1981. Areal Distribution of ${ }^{60} \mathrm{Co},{ }^{137} \mathrm{Cs}$, and ${ }^{90} \mathrm{Sr}$ In Streambed Gravels of White Oak Creek Watershed Oak Ridge, Tennessee. ORNL/TM-7318. Oak Ridge National Laboratory, Oak Ridge, Tennessee.

Cox, D. K, et al. (1991) The New Definitive Map of White Oak Lake, ORNL/TM-11204, Oak Ridge National Laboratory, Oak Ridge, Tennessee.

DOE (Department of Energy). 1988. Historical Radionuclides Releases from Current DOE Oak Ridge Operations Office Facilities. U.S. Department of Energy Oak Ridge Field Office, Oak Ridge, Tennessee, pp. 36.

Edgar, D. E. 1987. An Analysis of Infrequent Hydrologic Events With Regards to Existing Streamflow Monitoring Capabilities in White Oak Creek Watershed. ORNL/TM-6542. Oak Ridge National Laboratory, Oak Ridge, Tennessee.

Energy Systems (Martin Marietta Energy Systems, Inc.). 1990. Clinch River RCRA Facility Investigation Plan, Draft, ES,ER-1/D1, Oak Ridge National Laboratory, Oak Ridge, Tennessee.

Energy Systems (Martin Marietta Energy Systems, Inc.). 1991. White Oak Creek Embayment Time-Critical CERCLA Removal Action Project. Functional Requirements Document. ORNL/M-1546. Originated by J. T. Etheridge. Oak Ridge National Laboratory, Oak Ridge, Tennessee, pp. 6.

EPA (U.S. Environmental Protection Agency). 1991. Drinking Water Regulations: Maximum Contaminant Level Goals and National Primary Drinking Water Regulations For Lead and Copper. Federal Register, Vol. 55, No. 110, June 7, 1991, pp. 26460-26564.

EPA (U.S. Environmental Protection Agency). 1990. Health Effects Assessment Summary Tables. Third Quarter, FY 1990, OERR 9200.6-303(89-4), EPA Office of Emergency and Remedial Response, Washington, D.C.

EPA (U.S. Environmental Protection Agency). 1989. Exposure Factors Handbook, EPA Office of Health and Environmental Assessment, Research and Development. EPA 600/8/89/043. Washington, DC.

ERDA (Energy Research and Development Administration). 1975. Preliminary Draft Environmental Analysis - Oak Ridge Operations, Vol. VI, Sect. 2.5.5 Mimeograph, 145 pp. plus appendixes.

Federal Register. 1990a. Toxicity Characteristic Leachate Procedures. Vol. 55, No. 61, March 29, 1990, pp. 111846.

Federal Register. 1990b. Toxicity Characteristic Leachate Procedures. Vol. 55, No. 61, March 29, 1990, pp. 11798-11877.

Federal Register. 1990c. Rules and Regulations. Volume 55, No. 45, March 8, 1991, pp. 8713. 
Fritzsche, A. E. 1987. An Aerial Radiological Survey of the White Oak Creek Floodplain Oak Ridge Reservation, Oak Ridge, Tennessee. EGG-10282-1136. EG\&G Energy Measurements, Las Vegas, Nevada.

Hoffman, F. O., et al. 1990. Preliminary Screening of Contaminants in the Off-Site Surface Water Environment Downstream of the U.S. Department of Energy Oak Ridge Reservation, Review Draft, ORNL/ER-9. Oak Ridge National Laboratory, Oak Ridge, Tennessee.

Kolehmainen, S. E., and D. J. Nelson. 1969. The Balances of ${ }^{137} \mathrm{Cs}$, Stable Cesium, and the Feeding Rates of Bluegill (Lepomis macrochirus Raf.) in White Oak Lake, ORNL-4445, Oak Ridge National Laboratory, Oak Ridge, Tennessee, pp. 114.

Krumholz, I. A. 1954. An Ecological Survey of White Oak Creek, 1950-1953, ORO-587 (Vol. I), U.S. Atomic Energy Commission, Division of Technical Information, Oak Ridge, Tennessee, pp. 158.

Lackey, J. B. 1957. The Suspended Microbiota of the Clinch River and Adjacent Waters, in Relation to Radioactivity in the Summer of 1956, ORNL-2410, Oak Ridge National Laboratory, Oak Ridge, Tennessee.

Lee, P. K, and S. I. Auerbach. 1959. Determination and Evaluation of the Radiation Field Above White Oak Lake Bed. ORNL-2755. Oak Ridge National Laboratory, Oak Ridge, Tennessee.

Loar, J. M. (ed). 1981. Ecological Studies of the Biotic Communities in the Vicinity of the Oak Ridge Gaseous Diffusion Plant. ORNL/TM-6714. Oak Ridge National Laboratory, Oak Ridge, Tennessee.

Loar, J. M. (ed). 1989. Third Annual Report on the ORNL Biological Monitoring and Abatement Program. ORNL/TM-Draft. Oak Ridge National Laboratory, Oak Ridge, Tennessee.

Loar, J. M. (ed). 1990. Fourth Annual Report on the ORNL Biological Monitoring and Abatement Program, Draft ORNL/TM Report, Oak Ridge National Laboratory, Oak Ridge, Tennessee.

Loar, J. M., J. A. Solomon, and G. F. Cada. 1981. Technical Background Information for the ORNL Environmental and Safety Report, Vol. 2, A Description of the Aquatic Ecology of White Oak Creek Watershed and the Clinch River Below Melton Hill Dam, ORNL/TM-7509/V2, Oak Ridge National Laboratory, Oak Ridge, Tennessee, pp. 198.

Lomenick, T. F., and D. A. Gardiner. 1965. The Occurrence and Retention of Radionuclides in Sediment of White Oak Lake. Health Physics 11:567-577.

McMaster, W. M., and H. D. Waller. 1965. Geology and Soils of White Oak Creek Basin, Tennessee, ORNL/TM-1108, Oak Ridge National Laboratory, Oak Ridge, Tennessee, 37 pp.

Morton, R. J. (ed). 1961. Status Report No. 1 on Clinch River Study. ORNL-3119. Oak Ridge National Laboratory, Oak Ridge, Tennessee.

McMaster, W. M. 1967. Hydrologic Data for the Oak Ridge Area, Tennessee, U.S. Geological Survey Water-Supply Paper 1839-N.

Oakes, T. W. et al. 1982a. Technical Background Information for the ORNL Environmental and Safety Report, Vol. 4: White Oak Lake and Dam, ORNL-5681, Oak Ridge National Laboratory, Oak Ridge, Tennessee.

Oakes, T. W. et al. 1982b. Technical Background Information for the ORNL Environmental and Safety Report, Vol. 5: The 1977 Clinch River Sediment Survey-Data Presentation. ORNL-5878. Oak Ridge National Laboratory, Oak Ridge, Tennessee. 
OSWER (Office of Solid Waste and Emergency Response). 1991. OSWER Directive 9285.6-03, March 25, 1991. Office of Emergency and Remedial Response Toxic Integration Branch, U.S. EPA, Washington, DC 20460.

Patania, V. P. 1991. White Oak Creek Embayment Exposure Rate Survey: High Pool Phase. (Letter to B. G. Blaylock, January 17, 1991). Oak Ridge National Laboratory, Oak Ridge, Tennessee.

Patania, V. P. 1991b. White Oak Creek Embayment Exposure Rate Survey: Low Pool Phase. (Letter to B. G. Blaylock, September 6, 1991). Oak Ridge National Laboratory, Oak Ridge, Tennessee.

Setter, L. R., and O. W. Kochtitzky. 1950. Studies of the White Oak Lake Drainage, ORNL-562, Oak Ridge National Laboratory, Oak Ridge, Tennessee, 16 pp.

Sherwood, C. B., and J. M. Loar. 1987. Environmental Data for the White Oak Creek/White Oak Lake Watershed, ORNL/TM-10062, Oak Ridge National Laboratory, Oak Ridge, Tennessee, pp. 92.

Smith, M. S. 1945. Report on White Oak Creek Dam Structure and Flood Operation. CL-455. Nuclear Division-Union Carbide Corporation, Oak Ridge, Tennessee.

Tschantz, B. A. 1987. White Oak Creek Hydrologic and Spillway Adequacy Analysis. ORNL/SUB/87-32-CT213V-1. Department of Civil Engineering, The university of Tennessee, Knoxville, Tennessee.

TVA (Tennessee Valley Authority). 1984. Preconstruction Radioactivity Levels in the Vicinity of the Proposed Clinch River Breeder Reactor Project. TVA/PUB-84-65. Muscle Shoals, Alabama.

TVA (Tennessee Valley Authority). 1985a. Instream Contaminant Study, Task 2: Sediment Characterization, Volume 1, Report to U.S. Department of Energy, Oak Ridge Operations Office, Tennessee Valley Authority, Office of Natural Resources and Economic Development, Knoxville, Tennessee, 82 pp.

TVA (Tennessee Valley Authority). 1985b. Instream Contaminant Study, Task 2: Sediment Characterization Volume II-Appendices, Report to U. S. Department of Energy, Oak Ridge Operations Office, Tennessee Valiey Authority, Office of Natural Resources and Economic Development, Knoxville, Tennessee, 450 pp.

TVA (Tennessee Valley Authority). 1986. Instream Contaminant Study-Task 5: Summary Report. Report to U.S. Department of Energy, Oak Ridge Operations. Tennessee Valley Authority, Office of Natural Resources and Economic Development, Knoxville, Tennessee.

U.S. Army Corps of Engineers. 1991. Evaluation of Alternatives for White Oak Creek Embayment Oak Ridge National Laboratory, Oak Ridge, Tennessee. January 1991, pp. 30. U.S. Army Corps of Engineers, Nashville District. 


\begin{abstract}
Appendix A
CONCENTRATIONS OF RADIONUCLIDES

IN WHITE OAK CREEK EMBAYMENT CORE SAMPLES

COLLECTED IN 1977
\end{abstract}


Table A 1. Summary of radionuclide concentrations in White Oak Creek Embayment core samples collected in 1977

\begin{tabular}{|c|c|c|c|c|c|c|}
\hline Compound & Number & $\begin{array}{c}\text { Minimum } \\
\text { Value }\end{array}$ & $\begin{array}{l}\text { Maximum } \\
\text { Value }\end{array}$ & $\begin{array}{c}\text { Mean } \\
\text { value }\end{array}$ & $\begin{array}{l}\text { Standard } \\
\text { Deviation }\end{array}$ & Units \\
\hline $\begin{array}{l}\text { Co- } 60 \\
\text { Cs-137 }\end{array}$ & $\begin{array}{l}242 \\
319\end{array}$ & $\begin{array}{l}6.18 \\
6.18\end{array}$ & $\begin{array}{r}35899.99 \\
3750653.00\end{array}$ & $\begin{array}{r}2450.56 \\
76087.64\end{array}$ & $\begin{array}{r}4704.06 \\
279432.80\end{array}$ & $\begin{array}{l}\mathrm{BQ} / \mathrm{KG} \\
\mathrm{BO} / \mathrm{KG}\end{array}$ \\
\hline
\end{tabular}


Table A2. Radionuclide concentrations in White Oak Creek Embayment core samples collected in 1977

\begin{tabular}{|c|c|c|c|c|}
\hline$\underset{10^{4}}{\text { Core }}$ & $\begin{array}{l}\text { Sample } \\
\text { Depth (in) }\end{array}$ & $\frac{\text { Co }}{\text { Cs-137 }}$ & $\frac{d}{C 0-60}$ & Units \\
\hline 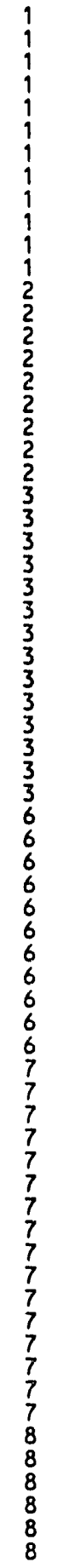 & $\begin{array}{l}1 \\
2 \\
3 \\
4 \\
5 \\
6 \\
6 \\
7 \\
8 \\
13 \\
14 \\
16 \\
17 \\
1 \\
2 \\
3 \\
4 \\
5 \\
6 \\
7 \\
13 \\
22 \\
1 \\
2 \\
3 \\
4 \\
5 \\
6 \\
7 \\
8 \\
10 \\
11 \\
12 \\
13 \\
14 \\
15 \\
1 \\
2 \\
3 \\
4 \\
5 \\
6 \\
7 \\
8 \\
9 \\
12 \\
18 \\
1 \\
2 \\
3 \\
4 \\
5 \\
6 \\
7 \\
8 \\
9 \\
10 \\
11 \\
12 \\
13 \\
14 \\
17 \\
20 \\
1 \\
2 \\
3 \\
4 \\
6\end{array}$ & $\begin{array}{r}25086.74 \\
24716.00 \\
16992.25 \\
17362.99 \\
15014.97 \\
13840.96 \\
4819.62 \\
741.48 \\
80.33 \\
37.07 \\
12.36 \\
30338.89 \\
3027.71 \\
2780.55 \\
1421.17 \\
679.69 \\
185.37 \\
185.37 \\
43.25 \\
556.11 \\
19093.11 \\
19649.22 \\
10504.30 \\
3954.56 \\
1421.17 \\
494.32 \\
308.95 \\
308.95 \\
49.43 \\
43.25 \\
37.07 \\
308.95 \\
123.58 \\
1359.38 \\
38618.75 \\
31698.27 \\
25333.90 \\
24407.05 \\
16065.40 \\
1915.49 \\
803.27 \\
247.16 \\
185.37 \\
30.89 \\
1359.38 \\
97628.20 \\
96392.40 \\
23912.73 \\
22800.51 \\
21317.55 \\
38927.70 \\
24530.63 \\
5993.63 \\
803.27 \\
432.53 \\
308.95 \\
432.53 \\
123.58 \\
123.58 \\
61.79 \\
741.48 \\
59874.51 \\
19525.64 \\
15385.71 \\
2409.81 \\
308.90\end{array}$ & $\begin{array}{r}3089.50 \\
2904.13 \\
2286.23 \\
2224.44 \\
1112.22 \\
865.06 \\
370.74 \\
49.43 \\
43.25 \\
55.61 \\
12.36 \\
6.18 \\
3027.71 \\
370.74 \\
370.74 \\
247.16 \\
123.58 \\
49.43 \\
30.89 \\
12.36 \\
49.43 \\
2595.18 \\
2533.39 \\
1421.17 \\
494.32 \\
185.37 \\
61.79 \\
37.07 \\
24.72 \\
12.36 \\
12.36 \\
6.18 \\
24.72 \\
30.89 \\
185.37 \\
4387.09 \\
3892.77 \\
3027.71 \\
2904.13 \\
1977.28 \\
185.37 \\
123.58 \\
30.89 \\
30.89 \\
24.72 \\
185.37 \\
7909.12 \\
7229.43 \\
1977.28 \\
1853.70 \\
1482.96 \\
2409.81 \\
1421.17 \\
370.74 \\
80.33 \\
30.89 \\
24.72 \\
24.72 \\
12.36 \\
18.54 \\
18.54 \\
61 . .79 \\
3583.82 \\
1112 . .22 \\
988.64 \\
123.58 \\
49.43 \\
18.54\end{array}$ & 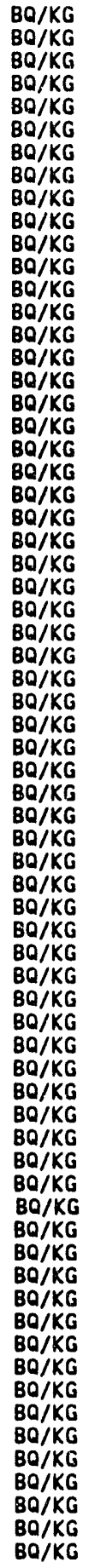 \\
\hline
\end{tabular}


Table A2 (continued)

\begin{tabular}{|c|c|c|c|c|}
\hline$\underset{10}{\text { Core }}$ & $\begin{array}{c}\text { Sample } \\
\text { Depth (in) }\end{array}$ & $\frac{C_{0}}{C s-137}$ & $\frac{n d}{C 0.60}$ & Units \\
\hline $\begin{array}{l}8 \\
8 \\
8 \\
8 \\
8 \\
8 \\
8 \\
11 \\
11 \\
11 \\
11 \\
11 \\
11 \\
11 \\
11 \\
11 \\
11 \\
11 \\
11 \\
11 \\
11 \\
12 \\
12 \\
12 \\
12 \\
12 \\
12 \\
12 \\
12 \\
12 \\
12 \\
12 \\
12 \\
12 \\
12 \\
12 \\
12 \\
12 \\
13 \\
13 \\
13 \\
13 \\
13 \\
13 \\
13 \\
13 \\
13 \\
16 \\
16 \\
16 \\
16 \\
16 \\
16 \\
16 \\
16 \\
16 \\
16 \\
17 \\
17 \\
17 \\
17 \\
17 \\
17 \\
17 \\
17 \\
17 \\
17 \\
17 \\
17 \\
17\end{array}$ & $\begin{array}{l}7 \\
8 \\
9 \\
10 \\
13 \\
16 \\
20 \\
1 \\
2 \\
3 \\
4 \\
5 \\
6 \\
7 \\
9 \\
10 \\
11 \\
12 \\
13 \\
14 \\
18 \\
1 \\
2 \\
3 \\
4 \\
5 \\
6 \\
7 \\
8 \\
9 \\
10 \\
11 \\
12 \\
13 \\
14 \\
15 \\
16 \\
23 \\
1 \\
2 \\
3 \\
4 \\
5 \\
6 \\
7 \\
8 \\
9 \\
1 \\
2 \\
3 \\
4 \\
5 \\
6 \\
7 \\
9 \\
10 \\
13 \\
1 \\
2 \\
3 \\
4 \\
5 \\
6 \\
7 \\
8 \\
9 \\
10 \\
11 \\
12 \\
13\end{array}$ & $\begin{array}{r}123.58 \\
123.58 \\
185.37 \\
247.16 \\
61.79 \\
61.79 \\
370.74 \\
41522.88 \\
39360.23 \\
35776.41 \\
26816.86 \\
26322.54 \\
18042.68 \\
8465.23 \\
10195.35 \\
24716.00 \\
62407.90 \\
76743.18 \\
57279.33 \\
25519.27 \\
3089.50 \\
137297.38 \\
147369.15 \\
150149.70 \\
167080.16 \\
41893.62 \\
17239.41 \\
17362.99 \\
6179.00 \\
2533.39 \\
1482.96 \\
1482.96 \\
1297.59 \\
1297.59 \\
537.57 \\
222.44 \\
61 . .79 \\
1977 . .28 \\
173938.85 \\
132786.71 \\
57897.23 \\
4387.09 \\
865.06 \\
1359.38 \\
926.85 \\
432 . .53 \\
1977.28 \\
18104.47 \\
7785.54 \\
4448.88 \\
2904.13 \\
1853.70 \\
1297.59 \\
803 . .27 \\
240.98 \\
173 . .01 \\
185.37 \\
305798.71 \\
227201.83 \\
271876.00 \\
368762.72 \\
440377 . .33 \\
325695 . .09 \\
220404.93 \\
141931 . .63 \\
88668.65 \\
52768.66 \\
37691.90 \\
14149.91 \\
8032.70\end{array}$ & $\begin{array}{r}24.72 \\
24.72 \\
18.54 \\
18.54 \\
12.36 \\
6.18 \\
30.89 \\
3027.71 \\
2965.92 \\
2471.60 \\
1297.59 \\
926.85 \\
803.27 \\
308.95 \\
67.97 \\
123.58 \\
160.65 \\
80.33 \\
55.61 \\
24.72 \\
37.07 \\
7538.38 \\
7847.33 \\
7661.96 \\
5561.10 \\
1606.54 \\
741.48 \\
741.48 \\
327.49 \\
160.65 \\
1117.40 \\
166.83 \\
123.58 \\
105.04 \\
86.51 \\
30.89 \\
12.36 \\
67.97 \\
9762.82 \\
9083.13 \\
3954.56 \\
494.32 \\
185.37 \\
123.58 \\
123.58 \\
49.43 \\
185.37 \\
1606.54 \\
741.48 \\
488.14 \\
346.02 \\
203.91 \\
117.40 \\
43.25 \\
18.54 \\
18.54 \\
6.18 \\
8835.97 \\
7414.80 \\
8527.02 \\
9515.66 \\
10751.46 \\
9083.13 \\
7909.12 \\
6117.21 \\
4078.14 \\
2471.60 \\
1730.12 \\
617.90 \\
537.57\end{array}$ & $\begin{array}{l}\mathrm{BQ} / \mathrm{KG} \\
\mathrm{BQ} / \mathrm{KG} \\
\mathrm{BQ} / \mathrm{KG} \\
\mathrm{BQ} / \mathrm{KG} \\
\mathrm{BQ} / \mathrm{KG} \\
\mathrm{BQ} / \mathrm{KG} \\
\mathrm{BQ} / \mathrm{KG} \\
\mathrm{BQ} / \mathrm{KG} \\
\mathrm{BQ} / \mathrm{KG} \\
\mathrm{BQ} / \mathrm{KG} \\
\mathrm{BQ} / \mathrm{KG} \\
\mathrm{BQ} / \mathrm{KG} \\
\mathrm{BQ} / \mathrm{KG} \\
\mathrm{BQ} / \mathrm{KG} \\
\mathrm{BQ} / \mathrm{KG} \\
\mathrm{BQ} / \mathrm{KG} \\
\mathrm{BQ} / \mathrm{KG} \\
\mathrm{BO} / \mathrm{KG} \\
\mathrm{BO} / \mathrm{KG} \\
\mathrm{BQ} / \mathrm{KG} \\
\mathrm{BQ} / \mathrm{KG} \\
\mathrm{BQ} / \mathrm{KG} \\
\mathrm{BO} / \mathrm{KG} \\
\mathrm{BQ} / \mathrm{KG} \\
\mathrm{BQ} / \mathrm{KG} \\
\mathrm{BO} / \mathrm{KG} \\
\mathrm{BQ} / \mathrm{KG} \\
\mathrm{BQ} / \mathrm{KG} \\
\mathrm{BQ} / \mathrm{KG} \\
\mathrm{BQ} / \mathrm{KG} \\
\mathrm{BQ} / \mathrm{KG} \\
\mathrm{BQ} / \mathrm{KG} \\
\mathrm{BQ} / \mathrm{KG} \\
\mathrm{BQ} / \mathrm{KG} \\
\mathrm{BQ} / \mathrm{KG} \\
\mathrm{BQ} / \mathrm{KG} \\
\mathrm{BQ} / \mathrm{KG} \\
\mathrm{BO} / \mathrm{KG} \\
\mathrm{BQ} / \mathrm{KG} \\
\mathrm{BQ} / \mathrm{KG} \\
\mathrm{BQ} / \mathrm{KG} \\
\mathrm{BQ} / \mathrm{KG} \\
\mathrm{BQ} / \mathrm{KG} \\
\mathrm{BQ} / \mathrm{KG} \\
\mathrm{BQ} / \mathrm{KG} \\
\mathrm{BQ} / \mathrm{KG} \\
\mathrm{BQ} / \mathrm{KG} \\
\mathrm{BQ} / \mathrm{KG} \\
\mathrm{BQ} / \mathrm{KG} \\
\mathrm{BQ} / \mathrm{KG} \\
\mathrm{BQ} / \mathrm{KG} \\
\mathrm{BQ} / \mathrm{KG} \\
\mathrm{BQ} / \mathrm{KG} \\
\mathrm{BQ} / \mathrm{KG} \\
\mathrm{BQ} / \mathrm{KG} \\
\mathrm{BQ} / \mathrm{KG} \\
\mathrm{BQ} / \mathrm{KG} \\
\mathrm{BQ} / \mathrm{KG} \\
\mathrm{BQ} / \mathrm{KG} \\
\mathrm{BQ} / \mathrm{KG} \\
\mathrm{BQ} / \mathrm{KG} \\
\mathrm{BQ} / \mathrm{KG} \\
\mathrm{BQ} / \mathrm{KG} \\
\mathrm{BQ} / \mathrm{KG} \\
\mathrm{BQ} / \mathrm{KG} \\
\mathrm{BQ} / \mathrm{KG} \\
\mathrm{BQ} / \mathrm{KG} \\
\mathrm{BQ} / \mathrm{KG} \\
\mathrm{BQ} / \mathrm{KG} \\
\mathrm{BQ} / \mathrm{KG}\end{array}$ \\
\hline
\end{tabular}


Table A2 (continued)

\begin{tabular}{|c|c|c|c|c|}
\hline $\begin{array}{c}\text { Core } \\
\text { ID }\end{array}$ & $\begin{array}{c}\text { Sample } \\
\text { Depth (in) }\end{array}$ & $\frac{\text { Comp }}{\text { Cs }-137}$ & $\mathrm{Co}-60$ & Units \\
\hline $\begin{array}{l}17 \\
17 \\
17 \\
17 \\
17 \\
18 \\
18 \\
18 \\
18 \\
18 \\
18 \\
18 \\
18 \\
18 \\
18 \\
18 \\
18 \\
18 \\
18 \\
18 \\
18 \\
19 \\
19 \\
19 \\
19 \\
19 \\
19 \\
19 \\
19 \\
19 \\
20 \\
20 \\
20 \\
20 \\
20 \\
20 \\
20 \\
20 \\
20 \\
20 \\
20 \\
20 \\
20 \\
20 \\
20 \\
20 \\
23 \\
23 \\
23 \\
23 \\
23 \\
23 \\
23 \\
23 \\
23 \\
23 \\
23 \\
23 \\
23 \\
23 \\
23 \\
23 \\
23 \\
23 \\
23 \\
23 \\
23 \\
23 \\
23 \\
23\end{array}$ & $\begin{array}{l}14 \\
15 \\
16 \\
18 \\
22 \\
1 \\
2 \\
3 \\
4 \\
5 \\
6 \\
7 \\
8 \\
9 \\
10 \\
11 \\
12 \\
13 \\
15 \\
16 \\
21 \\
1 \\
2 \\
3 \\
4 \\
5 \\
6 \\
7 \\
8 \\
25 \\
1 \\
2 \\
3 \\
4 \\
5 \\
6 \\
7 \\
8 \\
9 \\
10 \\
11 \\
12 \\
13 \\
15 \\
16 \\
17 \\
1 \\
2 \\
3 \\
4 \\
5 \\
6 \\
7 \\
8 \\
9 \\
10 \\
11 \\
12 \\
13 \\
14 \\
15 \\
16 \\
17 \\
18 \\
19 \\
20 \\
21 \\
22 \\
23 \\
24\end{array}$ & $\begin{array}{r}5931.84 \\
1915.49 \\
617.90 \\
247.16 \\
10504.30 \\
184504.94 \\
237088.23 \\
251670.667 \\
250805 . .61 \\
250496.66 \\
244070.50 \\
211816.12 \\
109244.72 \\
76125 . .28 \\
30091.73 \\
25210.32 \\
1544.75 \\
4634.25 \\
1359.38 \\
865.06 \\
5066.78 \\
75507.38 \\
57402.91 \\
18598.79 \\
8341.65 \\
7167.64 \\
1359.38 \\
1174.01 \\
253.34 \\
1050.43 \\
27125.81 \\
16559.72 \\
14026.33 \\
5622.89 \\
2656.97 \\
1791.91 \\
2348.02 \\
2100.86 \\
543.75 \\
296.59 \\
451.07 \\
129.76 \\
346.02 \\
352.20 \\
339.84 \\
3089.50 \\
63025.80 \\
60924.94 \\
62469.69 \\
71367.45 \\
81686.38 \\
86567.79 \\
96145.24 \\
107391.02 \\
101768.13 \\
102386.03 \\
98307.89 \\
99111.16 \\
106031.64 \\
113446.44 \\
111283.79 \\
113878.97 \\
113508.23 \\
126669.50 \\
130376.90 \\
195071.03 \\
470221.90 \\
797091.00 \\
1099862.00 \\
1309948.00\end{array}$ & $\begin{array}{r}420.17 \\
160.65 \\
67.97 \\
30.89 \\
203.91 \\
6426.16 \\
7229.43 \\
7229.43 \\
7291.22 \\
6858.69 \\
6673.32 \\
5499.31 \\
2842.34 \\
1977 . .28 \\
803.27 \\
741.48 \\
49.43 \\
117.40 \\
37.07 \\
18.54 \\
129.76 \\
5313.94 \\
3769.19 \\
988.64 \\
451.07 \\
389.28 \\
74.15 \\
61.79 \\
18.54 \\
661.79 \\
2224.44 \\
1730.12 \\
1544.75 \\
679.69 \\
271.88 \\
123.58 \\
123.58 \\
135.94 \\
80.33 \\
49.43 \\
61.79 \\
37.07 \\
49.43 \\
30.89 \\
30.89 \\
240.98 \\
2286.23 \\
2162.65 \\
2286.23 \\
2656.97 \\
3274.87 \\
3274.87 \\
3151.29 \\
3089.50 \\
2904.13 \\
2965.92 \\
3089.50 \\
2656.97 \\
2409.81 \\
2595.18 \\
2595.18 \\
2595.18 \\
2533.39 \\
2718.76 \\
2348.02 \\
3645.61 \\
7661.96 \\
14458.86 \\
17424.78 \\
14026.33\end{array}$ & 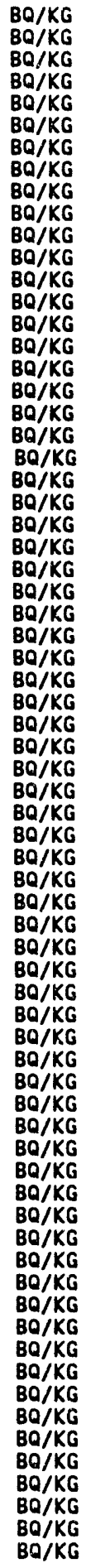 \\
\hline
\end{tabular}


Table A2 (continued)

\begin{tabular}{|c|c|c|c|c|}
\hline \multirow{2}{*}{ Core } & \multirow{2}{*}{$\begin{array}{c}\text { Sample } \\
\text { Depth (in) }\end{array}$} & \multicolumn{2}{|c|}{ Compound } & \multirow[b]{2}{*}{ Units } \\
\hline & & $\overline{c s-137}$ & $\mathrm{Co}-60$ & \\
\hline $\begin{array}{l}23 \\
23 \\
23 \\
23 \\
23 \\
23 \\
23 \\
23 \\
23 \\
23 \\
23 \\
23 \\
24 \\
24 \\
24 \\
24 \\
24 \\
24 \\
24 \\
24 \\
24 \\
24 \\
24 \\
24 \\
24 \\
24 \\
24 \\
24 \\
24 \\
24 \\
24 \\
24 \\
24 \\
24\end{array}$ & $\begin{array}{l}25 \\
26 \\
27 \\
28 \\
29 \\
30 \\
30.5 \\
31 \\
32 \\
33 \\
34 \\
35 \\
1 \\
2 \\
3 \\
4 \\
5 \\
6 \\
7 \\
8 \\
9 \\
10 \\
11 \\
12 \\
13 \\
14 \\
15 \\
16 \\
17 \\
18 \\
19 \\
20 \\
21 \\
22\end{array}$ & $\begin{array}{r}1810447.00 \\
3750653.00 \\
1371738.00 \\
982461.00 \\
766196.00 \\
363016.25 \\
98246.10 \\
56661.43 \\
95589.13 \\
36456.10 \\
33490.18 \\
180859.33 \\
32501.54 \\
29226.67 \\
33366.60 \\
36085.36 \\
29041.30 \\
27125.81 \\
15941.82 \\
10133.56 \\
59689.14 \\
146380.51 \\
252659.31 \\
267612.49 \\
192166.90 \\
265944.16 \\
219416.29 \\
66177.09 \\
21193.99 \\
18351.63 \\
18475.21 \\
36641.47 \\
116968.47 \\
88174.33\end{array}$ & $\begin{array}{r}23665.57 \\
35899.99 \\
30771.42 \\
27558.34 \\
20514.28 \\
8897.76 \\
3954.56 \\
2471.60 \\
3707.40 \\
2904.13 \\
2965.92 \\
4696.04 \\
741.48 \\
679.69 \\
803.27 \\
865.06 \\
617.90 \\
679.69 \\
444.89 \\
302.77 \\
988.64 \\
2100.86 \\
2100.86 \\
1668.33 \\
1359.38 \\
1977.28 \\
1174.01 \\
407.81 \\
173.01 \\
179.19 \\
210.09 \\
494.32 \\
1853.70 \\
18.54\end{array}$ & $\begin{array}{l}B Q / K G \\
B Q / K G \\
B O / K G \\
B O / K G \\
B Q / K G \\
B O / K G \\
B Q / K G \\
B Q / K G \\
B Q / K G \\
B Q / K G \\
B Q / K G \\
B Q / K G \\
B Q / K G \\
B Q / K G \\
B Q / K G \\
B Q / K G \\
B Q / K G \\
B Q / K G \\
B Q / K G \\
B Q / K G \\
B Q / K G \\
B Q / K G \\
B Q / K G \\
B Q / K G \\
B Q / K G \\
B Q / K G \\
B Q / K G \\
B Q / K G \\
B O / K G \\
B Q / K G \\
B Q / K G \\
B Q / K G \\
B Q / K G \\
B Q / K G\end{array}$ \\
\hline
\end{tabular}

'Cores 13, 18, 19, 23, and 24 were used to calculate radionuclide inventories. 
Appendix B

CONCENTRATIONS OF CONTAMINANTS

IN TVA CORE SAMPLES COLLECTED IN WHITE OAK CREEK IN 1984 
61

Table B1. Summary of contaminant concentrations in TVA core samples collected in 1984

\begin{tabular}{|c|c|c|c|c|c|c|c|c|c|}
\hline $\begin{array}{c}\text { Analysis } \\
\text { Type }\end{array}$ & Compound & Number & $\begin{array}{l}\text { Minimum } \\
\text { Qual ifier }\end{array}$ & $\begin{array}{c}\text { Minimum } \\
\text { Value }\end{array}$ & $\begin{array}{l}\text { Maximum } \\
\text { Qualifier }\end{array}$ & $\begin{array}{l}\text { Maximum } \\
\text { Value }\end{array}$ & $\begin{array}{l}\text { Mean } \\
\text { Value }\end{array}$ & $\begin{array}{l}\text { Standard } \\
\text { Deviation }\end{array}$ & Units \\
\hline \multicolumn{10}{|l|}{ METALS } \\
\hline & $\begin{array}{l}\text { ARSENIC } \\
\text { CADMIUM } \\
\text { CHROMIUM } \\
\text { CYANIDE } \\
\text { LEAD } \\
\text { MERCURY } \\
\text { NICKEL } \\
\text { SILVER } \\
\text { URANIUM } \\
\text { ZIRCONIUM }\end{array}$ & $\begin{array}{r}4 \\
4 \\
4 \\
4 \\
4 \\
4 \\
4 \\
4 \\
23 \\
4\end{array}$ & A & $\begin{array}{r}5.00 \\
0.60 \\
66.00 \\
1.00 \\
33.00 \\
2.20 \\
25.00 \\
2.00 \\
0.30 \\
260.00\end{array}$ & A & $\begin{array}{r}12.00 \\
2.60 \\
290.00 \\
1.00 \\
51.00 \\
6.00 \\
30.00 \\
10.00 \\
18.00 \\
450.00\end{array}$ & $\begin{array}{r}8.25 \\
1.62 \\
183.00 \\
1.00 \\
40.25 \\
3.40 \\
26.25 \\
6.25 \\
4.71 \\
352.50\end{array}$ & $\begin{array}{r}3.77 \\
0.93 \\
118.48 \\
0.00 \\
7.63 \\
1.75 \\
2.50 \\
3.86 \\
3.87 \\
96.39\end{array}$ & $\begin{array}{l}M G / K G \\
M G / K G \\
M G ! K G \\
M G / K G \\
M G / K G \\
M G / K G \\
M G / K G \\
M G / K G \\
M G / K G \\
M G / K G\end{array}$ \\
\hline \multicolumn{10}{|l|}{ ORGAHICS } \\
\hline & 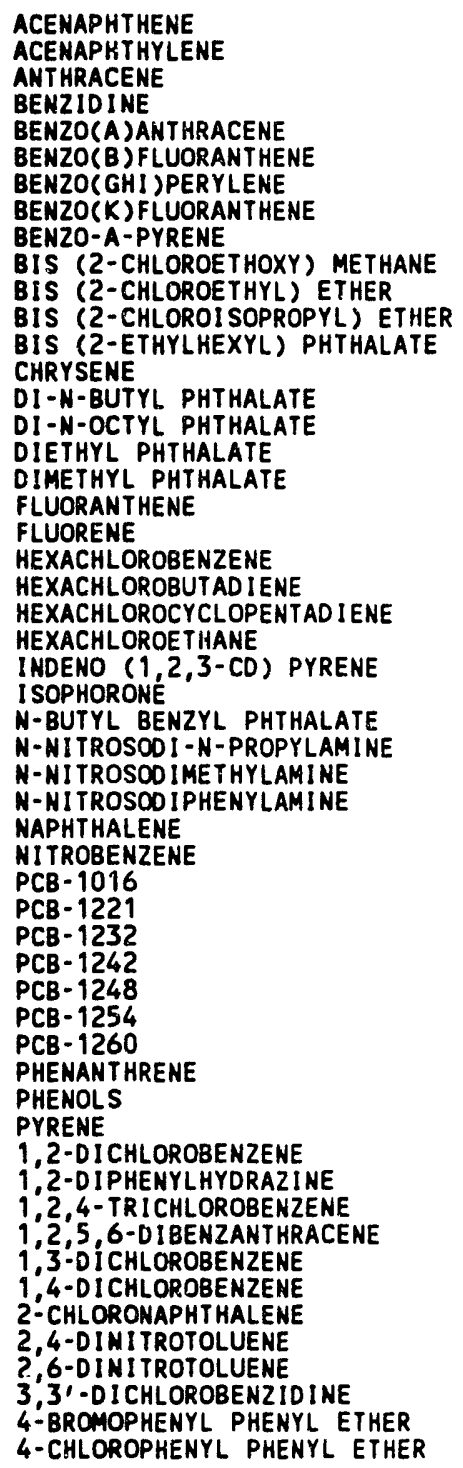 & $\begin{array}{l}4 \\
4 \\
4 \\
4 \\
4 \\
4 \\
4 \\
4 \\
4 \\
4 \\
4 \\
4 \\
4 \\
4 \\
4 \\
4 \\
4 \\
4 \\
4 \\
4 \\
4 \\
4 \\
4 \\
4 \\
4 \\
4 \\
4 \\
4 \\
4 \\
4 \\
4 \\
4 \\
4 \\
4 \\
4 \\
4 \\
4 \\
4 \\
4 \\
4 \\
4 \\
4 \\
4 \\
4 \\
4 \\
4 \\
4 \\
4 \\
4\end{array}$ & $\begin{array}{l}U \\
U \\
U \\
U \\
U \\
U \\
U \\
U \\
U \\
U \\
U \\
U \\
U \\
U \\
U \\
U \\
U \\
U \\
U \\
U \\
U \\
U \\
U \\
U \\
U \\
U \\
U \\
U \\
U \\
U \\
U \\
U \\
U \\
U \\
U \\
U \\
U \\
U \\
U \\
U \\
U \\
U \\
U \\
U \\
U \\
U \\
U \\
U \\
U \\
U \\
U \\
U \\
U \\
U\end{array}$ & $\begin{array}{l}0.63 \\
0.63 \\
0.63 \\
3.20 \\
0.63 \\
0.63 \\
0.63 \\
0.63 \\
0.63 \\
0.63 \\
0.63 \\
0.63 \\
0.63 \\
0.63 \\
0.63 \\
0.63 \\
0.63 \\
0.63 \\
0.63 \\
0.63 \\
0.63 \\
0.63 \\
0.63 \\
0.63 \\
0.63 \\
0.63 \\
0.63 \\
0.63 \\
0.63 \\
0.63 \\
0.63 \\
0.63 \\
0.10 \\
0.10 \\
0.10 \\
0.10 \\
0.10 \\
0.10 \\
0.10 \\
0.63 \\
0.40 \\
0.63 \\
0.63 \\
0.63 \\
0.63 \\
0.63 \\
0.63 \\
0.63 \\
0.63 \\
0.63 \\
0.63 \\
1.60 \\
0.63 \\
0.63\end{array}$ & 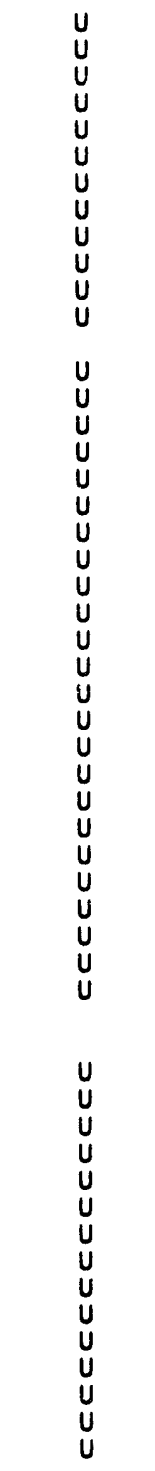 & $\begin{array}{l}0.82 \\
0.82 \\
0.82 \\
4.10 \\
0.82 \\
0.82 \\
0.82 \\
0.82 \\
0.82 \\
0.82 \\
0.82 \\
0.82 \\
1.60 \\
0.82 \\
0.82 \\
0.82 \\
0.82 \\
0.82 \\
0.82 \\
0.82 \\
0.82 \\
0.82 \\
0.82 \\
0.82 \\
0.82 \\
0.82 \\
0.82 \\
0.82 \\
0.82 \\
0.82 \\
0.82 \\
0.82 \\
0.10 \\
0.10 \\
0.10 \\
0.10 \\
0.10 \\
1.20 \\
1.60 \\
0.82 \\
0.40 \\
0.82 \\
0.82 \\
0.82 \\
0.82 \\
0.82 \\
0.82 \\
0.82 \\
0.82 \\
0.82 \\
0.82 \\
2.10 \\
0.82 \\
0.82\end{array}$ & $\begin{array}{l}0.75 \\
0.75 \\
0.75 \\
3.80 \\
0.75 \\
0.75 \\
0.75 \\
0.75 \\
0.75 \\
0.75 \\
0.75 \\
0.75 \\
0.95 \\
0.75 \\
0.75 \\
0.75 \\
0.75 \\
0.75 \\
0.75 \\
0.75 \\
0.75 \\
0.75 \\
0.75 \\
0.75 \\
0.75 \\
0.75 \\
0.75 \\
0.75 \\
0.75 \\
0.75 \\
0.75 \\
0.75 \\
0.10 \\
0.10 \\
0.10 \\
0.10 \\
0.10 \\
0.37 \\
0.47 \\
0.75 \\
0.40 \\
0.75 \\
0.75 \\
0.75 \\
0.75 \\
0.75 \\
0.75 \\
0.75 \\
0.75 \\
0.75 \\
0.75 \\
1.92 \\
0.75 \\
0.75\end{array}$ & $\begin{array}{l}0.09 \\
0.09 \\
0.09 \\
0.42 \\
0.09 \\
0.09 \\
0.09 \\
0.09 \\
0.09 \\
0.09 \\
0.09 \\
0.09 \\
0.44 \\
0.09 \\
0.09 \\
0.09 \\
0.09 \\
0.09 \\
0.09 \\
0.09 \\
0.09 \\
0.09 \\
0.09 \\
0.09 \\
0.09 \\
0.09 \\
0.09 \\
0.09 \\
0.09 \\
0.09 \\
0.09 \\
0.09 \\
0.00 \\
0.00 \\
0.00 \\
0.00 \\
0.00 \\
0.55 \\
0.75 \\
0.09 \\
0.00 \\
0.09 \\
0.09 \\
0.09 \\
0.09 \\
0.09 \\
0.09 \\
0.09 \\
0.09 \\
0.09 \\
0.09 \\
0.24 \\
0.09 \\
0.09\end{array}$ & $\begin{array}{l}M G / K G \\
M G / K G \\
M G / K G \\
M G / K G \\
M G / K G \\
M G / K G \\
M G / K G \\
M G / K G \\
M G / K G \\
M G / K G \\
M G / K G \\
M G / K G \\
M G / K G \\
M G / K G \\
M G / K G \\
M G / K G \\
M G / K G \\
M G / K G \\
M G / K G \\
M G / K G \\
M G / K G \\
M G / K G \\
M G / K G \\
M G / K G \\
M G / K G \\
M G / K G \\
M G / K G \\
M G / K G \\
M G / K G \\
M G / K G \\
M G / K G \\
M G / K G \\
M G / K G \\
M G / K G \\
M G / K G \\
M G / K G \\
M G / K G \\
M G / K G \\
M G / K G \\
M G / K G \\
M G / K G \\
M G / K G \\
M G / K G \\
M G / K G \\
M G / K G \\
M G / K G \\
M G / K G \\
M G / K G \\
M G / K G \\
M G / K G \\
M G / K G \\
M G / K G \\
M G / K G \\
M G / K G\end{array}$ \\
\hline
\end{tabular}


Table B1 (continued)

\begin{tabular}{|c|c|c|c|c|c|c|c|c|c|}
\hline $\begin{array}{l}\text { Analysis } \\
\text { Type }\end{array}$ & & Compound & Number & $\begin{array}{l}\text { Minimum } \\
\text { Qualifier }\end{array}$ & $\begin{array}{l}\text { Minimum } \\
\text { Value }\end{array}$ & $\begin{array}{l}\text { Maximum Maximum } \\
\text { Qualifier Value }\end{array}$ & $\begin{array}{l}\text { Mean } \\
\text { Value }\end{array}$ & $\begin{array}{l}\text { Standard } \\
\text { Deviation }\end{array}$ & Units \\
\hline \multicolumn{10}{|c|}{ RADIONUCLIDES } \\
\hline & $\begin{array}{l}A C-228 \\
A M-241 \\
B 1-212 \\
B 1-214 \\
C O-60 \\
C S-134 \\
C S-137 \\
C M-244 \\
E U-152 \\
E U-154 \\
P B-212 \\
P B-214 \\
P U-238 \\
P U-239 \\
\text { SR }-89 \\
\text { SR }-90 \\
T H-234 \\
T L-208\end{array}$ & & $\begin{array}{l}20 \\
15 \\
2 \\
15 \\
23 \\
18 \\
23 \\
9 \\
7 \\
19 \\
20 \\
5 \\
9 \\
9 \\
23 \\
23 \\
1 \\
7\end{array}$ & 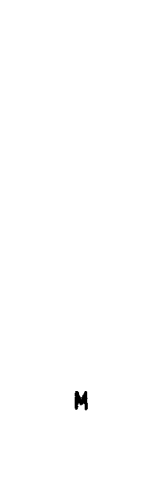 & $\begin{array}{r}37.00 \\
15.91 \\
111.00 \\
22.20 \\
444.00 \\
7.40 \\
6956.00 \\
0.52 \\
48.10 \\
19.98 \\
37.00 \\
37.00 \\
0.26 \\
13.32 \\
11.10 \\
74.00 \\
74.00 \\
14.80\end{array}$ & $\begin{array}{r}259.00 \\
2701 . .00 \\
111.00 \\
62 . .90 \\
16169.00 \\
62.90 \\
1737076.00 \\
444.00 \\
329.30 \\
518.00 \\
185.00 \\
51.80 \\
151.70 \\
2553.00 \\
6327.00 \\
29600.00 \\
74.00 \\
51.80\end{array}$ & $\begin{array}{r}94.90 \\
402.02 \\
111.00 \\
45.39 \\
4275.91 \\
24.46 \\
291650.09 \\
121.02 \\
216.71 \\
197.54 \\
81.03 \\
44.40 \\
23.07 \\
335.10 \\
1256.87 \\
5809.00 \\
74.00 \\
26.27\end{array}$ & $\begin{array}{r}55.32 \\
671.23 \\
0.00 \\
10.42 \\
3545.68 \\
15.34 \\
417175.81 \\
155.80 \\
106.25 \\
162.29 \\
44.99 \\
6.92 \\
48.63 \\
832.16 \\
1640.39 \\
7931.53 \\
12.29\end{array}$ & $\begin{array}{l}B Q / K G \\
B O / K G \\
B Q / K G \\
B Q / K G \\
B Q / K G \\
B O / K G \\
B O / K G \\
B Q / K G \\
B Q / K G \\
B O / K G \\
B Q / K G \\
B Q / K G \\
B O / K G \\
B O / K G \\
B Q / K G \\
B Q / K G \\
B O / K G \\
B Q / K G\end{array}$ \\
\hline
\end{tabular}

$U=$ below the limit of detection.

$A=$ dupl icate samples averaged.

$\hat{M}=$ presence of material verified but not quantified. 
63

Table B2. Contaminant concentrations in TVA core samples collected in 1984

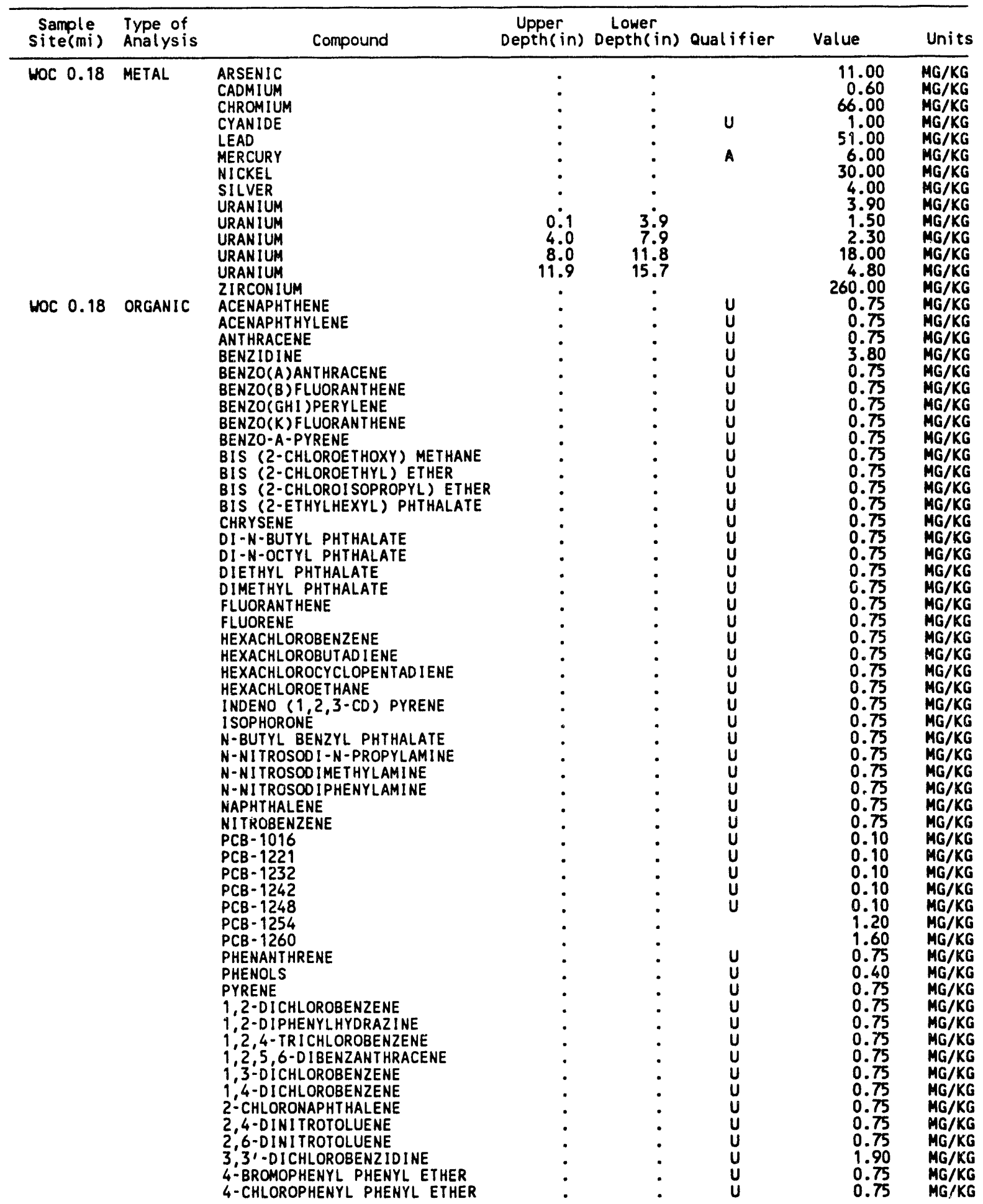


64

Table B2 (continued)

\begin{tabular}{|c|c|c|c|c|c|c|c|c|}
\hline $\begin{array}{c}\text { Sample } \\
\text { site(mi) }\end{array}$ & $\begin{array}{l}\text { Type of } \\
\text { Analys is }\end{array}$ & & Compound & $\begin{array}{l}\text { Upper } \\
\text { Depth(in) }\end{array}$ & $\begin{array}{l}\text { Lower } \\
\text { Depth(in) }\end{array}$ & Qualifier & Value & Units \\
\hline WOC 0.18 & $\begin{array}{l}\text { RADIO- } \\
\text { NUCLIDES }\end{array}$ & 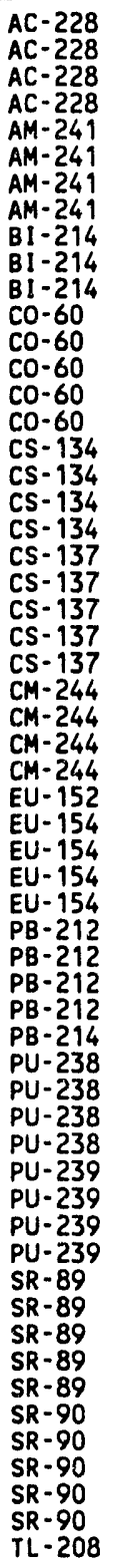 & & $\begin{array}{r}0.1 \\
4.0 \\
11.9 \\
0.1 \\
4.0 \\
8.0 \\
11.9 \\
0.1 \\
4.0 \\
11.9 \\
0.1 \\
4.0 \\
8.0 \\
11.9 \\
0.1 \\
0.1 \\
4.0 \\
4.0 \\
0.1 \\
4.1 \\
8.0 \\
11.0 \\
0.1 \\
4.0 \\
8.0 \\
11.9 \\
4.0 \\
0.1 \\
4.0 \\
8.0 \\
0.1 \\
4.1 \\
4.0 \\
11.9 \\
11.9 \\
0.1 \\
4.0 \\
8.0 \\
11.9 \\
0.1 \\
4.0 \\
8.0 \\
11.9 \\
0.9 \\
4.0 \\
8.0 \\
11.9 \\
0.9 \\
4.0 \\
8.0 \\
11.9 \\
11.9\end{array}$ & $\begin{array}{r}3.9 \\
7.9 \\
15.7 \\
3.9 \\
7.9 \\
11.8 \\
15.7 \\
3.9 \\
7.9 \\
15.7 \\
3.9 \\
7.9 \\
11.8 \\
15.7 \\
3.9 \\
3.9 \\
7.9 \\
7.9 \\
3.9 \\
7.9 \\
11.8 \\
15.7 \\
3.9 \\
7.9 \\
11.8 \\
15.7 \\
7.9 \\
3.9 \\
7.9 \\
11.8 \\
3.9 \\
7.9 \\
15.7 \\
15.7 \\
3.9 \\
7.9 \\
11.8 \\
15.7 \\
3.9 \\
7.9 \\
11.8 \\
15.7 \\
3.9 \\
7.9 \\
11.8 \\
15.7 \\
3.9 \\
7.9 \\
11.8 \\
15.7 \\
15.7\end{array}$ & $\begin{array}{l}K \\
M \\
M\end{array}$ & $\begin{array}{r}148.00 \\
37.00 \\
92.50 \\
81.40 \\
81.40 \\
133.20 \\
518.00 \\
17.76 \\
44.40 \\
51.80 \\
44.40 \\
4033.00 \\
1998.00 \\
4625.00 \\
16169.00 \\
1332.00 \\
11.10 \\
22.20 \\
18.50 \\
62.90 \\
448366.00 \\
7337.00 \\
78218.00 \\
1737076.00 \\
23532.00 \\
23.31 \\
255.30 \\
14.80 \\
0.52 \\
259.00 \\
111.00 \\
59.20 \\
296.00 \\
518.00 \\
148.00 \\
66.60 \\
111.00 \\
66.60 \\
51.80 \\
33.33 \\
12.21 \\
151.70 \\
0.33 \\
45.83 \\
88.80 \\
2553.00 \\
32.93 \\
2960.00 \\
111.00 \\
148.00 \\
4292.00 \\
1258.00 \\
29600.00 \\
74.00 \\
74.00 \\
20831.00 \\
5661.00 \\
22.20\end{array}$ & 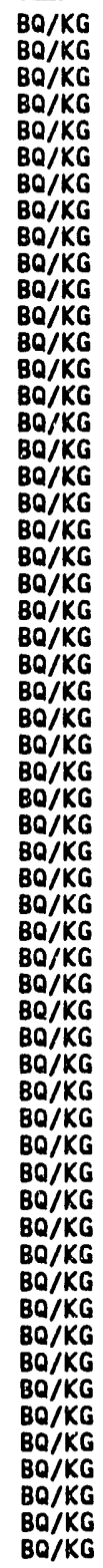 \\
\hline
\end{tabular}


65

Table B2 (continued)

\begin{tabular}{|c|c|c|c|c|c|c|c|}
\hline $\begin{array}{c}\text { Sample } \\
\text { site(mi) }\end{array}$ & $\begin{array}{l}\text { Type of } \\
\text { Analysis }\end{array}$ & Compound & $\begin{array}{l}\text { Upper } \\
\text { Depth(in) }\end{array}$ & $\begin{array}{l}\text { Lower } \\
\text { Depth(in) }\end{array}$ & Qualifier & Value & Units \\
\hline HOC 0.38 & ORGANIC & 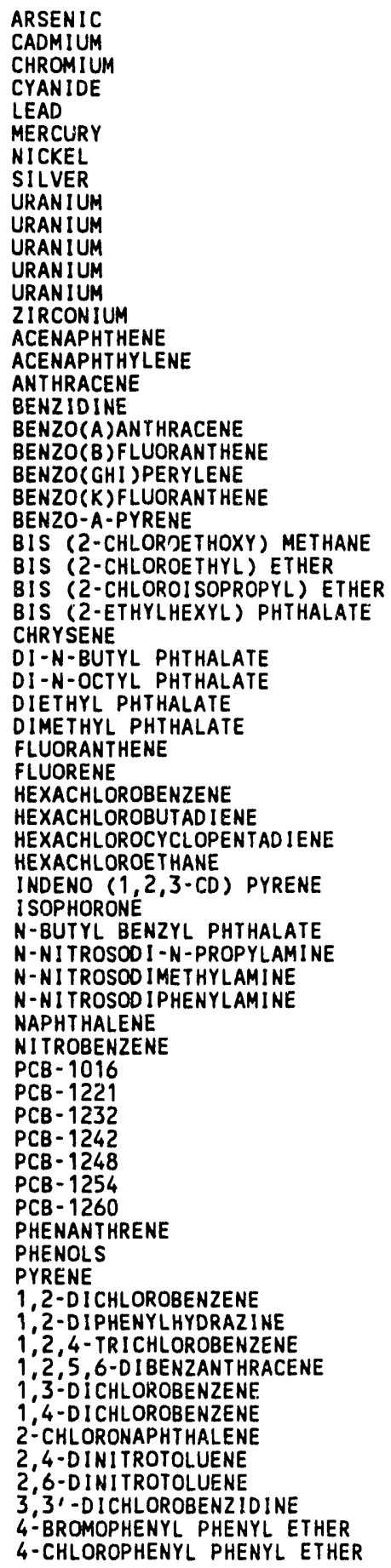 & $\begin{array}{l}: \\
: \\
: \\
: \\
0: \\
3: \\
0 . \\
: \\
: \\
: \\
: \\
: \\
: \\
: \\
: \\
: \\
: \\
: \\
: \\
: \\
: \\
: \\
: \\
: \\
: \\
: \\
: \\
: \\
: \\
: \\
: \\
: \\
: \\
: \\
: \\
: \\
: \\
: \\
: \\
: \\
:\end{array}$ & 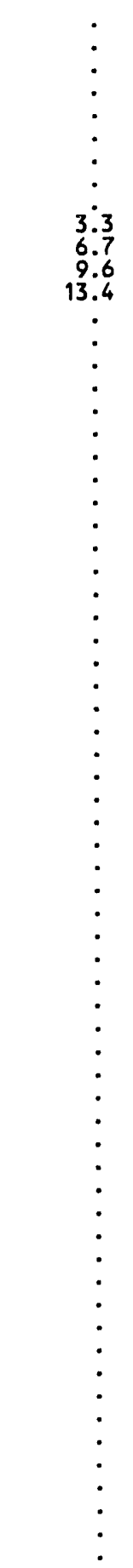 & $\begin{array}{l}U \\
U \\
U \\
U \\
U \\
U \\
U \\
U \\
U \\
U \\
U \\
U \\
U \\
U \\
U \\
U \\
U \\
U U \\
U \\
U \\
U \\
U \\
U \\
U \\
U \\
U \\
U \\
U \\
U \\
U \\
U \\
U \\
U \\
U \\
U \\
U \\
U \\
U \\
U \\
U \\
U U \\
U \\
U \\
U \\
U \\
U \\
U \\
U \\
U \\
U \\
U \\
U \\
U\end{array}$ & $\begin{array}{r}12.00 \\
1.10 \\
96.00 \\
1.00 \\
33.00 \\
2.20 \\
25.00 \\
2.00 \\
1.60 \\
0.30 \\
11.00 \\
7.00 \\
3.70 \\
280.00 \\
0.63 \\
0.63 \\
0.63 \\
3.20 \\
0.63 \\
0.63 \\
0.63 \\
0.63 \\
0.63 \\
0.63 \\
0.63 \\
0.63 \\
0.63\end{array}$ & $\begin{array}{l}M G / K G \\
M G / K G \\
M G / K G \\
M G / K G \\
M G / K G \\
M G / K G \\
M G / K G \\
M G / K G \\
M G / K G \\
M G / K G \\
M G / K G \\
M G / K G \\
M G / K G \\
M G / K G \\
M G / K G \\
M G / K G \\
M G / K G \\
M G / K G \\
M G / K G \\
M G / K G \\
M G / K G \\
M G / K G \\
M G / K G \\
M G / K G \\
M G / K G \\
M G / K G \\
M G / K G \\
M G / K G \\
M G / K G \\
M G / K G \\
M G / K G \\
M G / K G \\
M G / K G \\
M G / K G \\
M G / K G \\
M G / K G \\
M G / K G \\
M G / K G \\
M G / K G \\
M G / K G \\
M G / K G \\
M G / K G \\
M G / K G \\
M G / K G \\
M G / K G \\
M G / K G \\
M G / K G \\
M G / K G \\
M G / K G \\
M G / K G \\
M G / K G \\
M G / K G \\
M G / K G \\
M G / K G \\
M G / K G \\
M G / K G \\
M G / K G \\
M G / K G \\
M G / K G \\
M G / K G \\
M G / K G \\
M G / K G \\
M G / K G \\
M G / K G \\
M G / K G \\
M G / K G \\
M G / K G \\
M G / K G \\
M\end{array}$ \\
\hline
\end{tabular}


66

Table B2 (continued)

\begin{tabular}{|c|c|c|c|c|c|c|c|c|}
\hline $\begin{array}{r}\text { Sample } \\
\text { site(mi) }\end{array}$ & $\begin{array}{l}\text { Type of } \\
\text { Analysis }\end{array}$ & & Compound & $\begin{array}{l}\text { Upper } \\
\text { Depth(in) }\end{array}$ & $\begin{array}{c}\text { Lower } \\
\text { Depth(in) }\end{array}$ & Qualifier & Value & Units \\
\hline WOC 0.51 & $\begin{array}{l}\text { RADIO- } \\
\text { NUCLIDES }\end{array}$ & 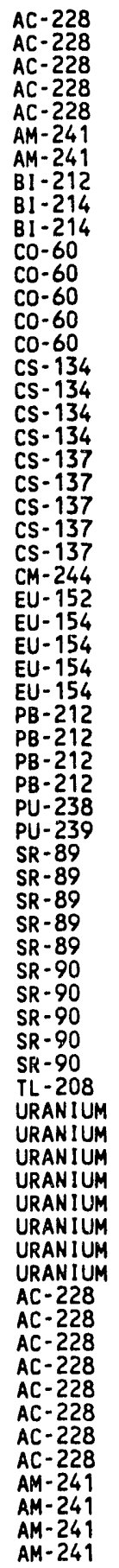 & & $\begin{array}{c}0.1 \\
3.4 \\
6.8 \\
9.7 \\
3.4 \\
9.7 \\
6.8 \\
9.7 \\
0.1 \\
3.4 \\
6.8 \\
9.7 \\
.0 \\
0.1 \\
0.1 \\
0.1 \\
3.4 \\
6.8 \\
9.7 \\
0.1 \\
0.1 \\
3.4 \\
6.8 \\
0.1 \\
3.4 \\
6.8 \\
9.7 \\
. \\
.0 \\
0.1 \\
3.4 \\
6.8 \\
9.7 \\
0.1 \\
3.4 \\
6.8 \\
9.7 \\
9.7 \\
0.1 \\
0.1 \\
5.0 \\
5.0 \\
9.9 \\
9.9 \\
14.9 \\
14.9 \\
0.1 \\
0.1 \\
5.0 \\
5.0 \\
9.9 \\
9.9 \\
14.9 \\
0.1 \\
5.0 \\
0.0\end{array}$ & $\begin{array}{r}3.3 \\
6.7 \\
9.6 \\
13.4 \\
6.7 \\
13.4 \\
9.6 \\
13.4 \\
3.3 \\
6.7 \\
9.6 \\
13.4 \\
. \\
3.3 \\
3.3 \\
3.3 \\
6.7 \\
9.6 \\
13.4 \\
3.3 \\
3.3 \\
6.7 \\
9.6 \\
3.3 \\
6.7 \\
9.6 \\
13.4 \\
. \\
. \\
3.3 \\
6.7 \\
9.6 \\
13.4 \\
3.3 \\
6.7 \\
9.6 \\
13.4 \\
13.4 \\
4.9 \\
4.9 \\
9.8 \\
9.8 \\
14.8 \\
14.8 \\
19.7 \\
19.7 \\
4.9 \\
4.9 \\
9.8 \\
9.8 \\
14.8 \\
14.8 \\
19.7 \\
19.7 \\
9.8 \\
9.8 \\
\end{array}$ & $\begin{array}{l}\mathbf{M} \\
\mathbf{M} \\
\mathbf{M} \\
\mathbf{M}\end{array}$ & $\begin{array}{r}66.60 \\
51.80 \\
148.00 \\
74.00 \\
66.60 \\
15.91 \\
481.00 \\
111.00 \\
40.70 \\
62.90 \\
2849.00 \\
2035.00 \\
10286.00 \\
4033.00 \\
629.00 \\
7.40 \\
25.90 \\
14.80 \\
18.50 \\
152477.00 \\
58941.00 \\
773485.00 \\
203759.00 \\
10249.00 \\
0.52 \\
48.10 \\
66.00 \\
40.70 \\
185.00 \\
25.90 \\
37.00 \\
148.00 \\
74.00 \\
59.20 \\
0.26 \\
37.74 \\
259.00 \\
111.00 \\
6327.00 \\
3367.00 \\
444.00 \\
999.00 \\
444.00 \\
20054.00 \\
9879.00 \\
259.00 \\
29.60 \\
0.70 \\
3.40 \\
3.00 \\
6.00 \\
6.80 \\
8.00 \\
4.50 \\
7.00 \\
74.00 \\
92.50 \\
148.00 \\
259.00 \\
148.00 \\
148.00 \\
55.50 \\
62.90 \\
370.00 \\
2701.00 \\
444.00 \\
703.00\end{array}$ & $\begin{array}{l}B Q / K G \\
B Q / K G \\
B Q / K G \\
B Q / K G \\
B Q / K G \\
B Q / K G \\
B Q / K G \\
B Q / K G \\
B Q / K G \\
B Q / K G \\
B Q / K G \\
B Q / K G \\
B Q / K G \\
B Q / K G \\
B Q / K G \\
B Q / K G \\
B Q / K G \\
B Q / K G \\
B Q / K G \\
B Q / K G \\
B Q / K G \\
B Q / K G \\
B Q / K G \\
B Q / K G \\
B Q / K G \\
B Q / K G \\
B Q / K G \\
B Q / K G \\
B Q / K G \\
B Q / K G \\
B Q / K G \\
B Q / K G \\
B Q / K G \\
B Q / K G \\
B Q / K G \\
B Q / K G \\
B Q / K G \\
B Q / K G \\
B Q / K G \\
B Q / K G \\
B Q / K G \\
B Q / K G \\
B Q / K G \\
B Q / K G \\
B Q / K G \\
8 Q / K G \\
B Q / K G \\
M G / K G \\
M G / K G \\
M G / K G \\
M G / K G \\
M G / K G \\
M G / K G \\
M G / K G \\
M G / K G \\
B Q / K G \\
B Q / K G \\
B Q / K G \\
B Q / K G \\
B Q / K G \\
B Q / K G \\
B Q / K G \\
B Q / K G \\
B Q / K G \\
B Q / K G \\
B Q / K G \\
B Q / K G \\
\end{array}$ \\
\hline
\end{tabular}


67

Table B2 (continued)

\begin{tabular}{|c|c|c|c|c|c|c|c|c|}
\hline $\begin{array}{r}\text { Sample } \\
\text { site(mi) }\end{array}$ & $\begin{array}{l}\text { Type of } \\
\text { Analysis }\end{array}$ & & Compound & $\begin{array}{c}\text { Upper } \\
\text { Depth( in) }\end{array}$ & $\begin{array}{c}\text { Lower } \\
\text { Depth(in) }\end{array}$ & Qualifier & Value & Units \\
\hline HOC 0.51 & $\begin{array}{l}\text { RADIO- } \\
\text { NUCLIDES }\end{array}$ & 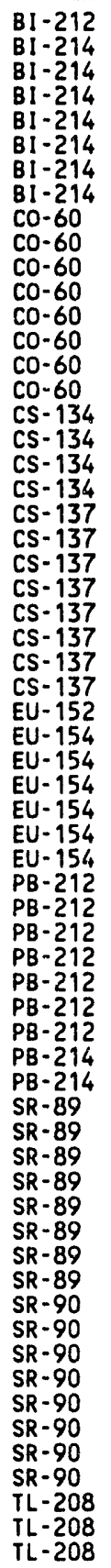 & & $\begin{array}{r}14.9 \\
0.1 \\
5.0 \\
5.0 \\
9.9 \\
9.9 \\
14.9 \\
14.9 \\
0.1 \\
0.1 \\
5.0 \\
5.0 \\
9.9 \\
9.9 \\
14.9 \\
14.9 \\
0.1 \\
0.1 \\
0.1 \\
0.1 \\
0.1 \\
0.1 \\
5.0 \\
5.0 \\
9.9 \\
9.9 \\
14.9 \\
14.9 \\
0.1 \\
0.1 \\
0.1 \\
5.0 \\
5.0 \\
9.9 \\
9.9 \\
0.1 \\
5.0 \\
5.0 \\
9.9 \\
9.9 \\
14.9 \\
14.9 \\
14.9 \\
14.9 \\
0.1 \\
0.1 \\
5.0 \\
5.0 \\
9.9 \\
9.9 \\
14.9 \\
14.9 \\
0.1 \\
0.1 \\
5.0 \\
5.0 \\
9.9 \\
9.9 \\
14.9 \\
14.9 \\
9.9 \\
14.9 \\
14.9\end{array}$ & $\begin{array}{r}19.7 \\
4.9 \\
9.8 \\
9.8 \\
14.8 \\
14.8 \\
19.7 \\
19.7 \\
4.9 \\
4.9 \\
9.8 \\
9.8 \\
14.8 \\
14.8 \\
19.7 \\
19.7 \\
4.9 \\
4.9 \\
4.9 \\
4.9 \\
4.9 \\
4.9 \\
9.8 \\
9.8 \\
14.8 \\
14.8 \\
19.7 \\
19.7 \\
4.9 \\
4.9 \\
4.9 \\
9.8 \\
9.8 \\
14.8 \\
14.8 \\
4.9 \\
9.8 \\
9.8 \\
14.8 \\
14.8 \\
19.7 \\
19.7 \\
19.7 \\
19.7 \\
4.9 \\
4.9 \\
9.8 \\
9.8 \\
14.8 \\
14.8 \\
19.7 \\
19.7 \\
4.9 \\
4.9 \\
9.8 \\
9.8 \\
14.8 \\
14.8 \\
19.7 \\
19.7 \\
14.8 \\
19.7 \\
19.7\end{array}$ & $\begin{array}{l}M \\
M \\
M \\
M \\
M \\
M \\
M \\
M\end{array}$ & $\begin{array}{r}111.00 \\
51.80 \\
37.00 \\
48.10 \\
55.50 \\
59.20 \\
40.70 \\
48.10 \\
4366.00 \\
4477.00 \\
5661.00 \\
6512.00 \\
4921.00 \\
6290.00 \\
444.00 \\
555.00 \\
14.80 \\
38.50 \\
33.30 \\
33.30 \\
160099.00 \\
319791.00 \\
702630.00 \\
969659.00 \\
314167.00 \\
468346.00 \\
12876.00 \\
20646.00 \\
259.00 \\
407.00 \\
481.00 \\
92.50 \\
333.00 \\
44.40 \\
55.50 \\
74.00 \\
148.00 \\
185.00 \\
81.40 \\
111.00 \\
44.40 \\
51.80 \\
37.00 \\
51.80 \\
296.00 \\
370.00 \\
1443.00 \\
2849.00 \\
1073.00 \\
1147.00 \\
962.00 \\
1110.00 \\
1332.00 \\
2775 . .00 \\
4699.00 \\
9139.00 \\
8510.00 \\
10249.00 \\
2627.00 \\
4033.00 \\
51.80 \\
22.20 \\
25.90\end{array}$ & $\begin{array}{l}B Q / K G \\
B Q / K G \\
B Q / K G \\
B Q / K G \\
B Q / K G \\
B Q / K G \\
B Q / K G \\
B Q / K G \\
B Q / K G \\
B Q / K G \\
B Q / K G \\
B Q / K G \\
B Q / K G \\
B Q / K G \\
B Q / K G \\
B Q / K G \\
B Q / K G \\
B Q / K G \\
B Q / K G \\
B Q / K G \\
B Q / K G \\
B Q / K G \\
B Q / K G \\
B Q / K G \\
B Q / K G \\
B Q / K G \\
B Q / K G \\
B Q / K G \\
B Q / K G \\
B Q / K G \\
B Q / K G \\
B Q / K G \\
B Q / K G \\
B Q / K G \\
B Q / K G \\
B Q / K G \\
B Q / K G \\
B Q / K G \\
B Q / K G \\
B Q / K G \\
B Q / K G \\
B Q / K G \\
B Q / K G \\
B Q / K G \\
B Q / K G \\
B Q / K G \\
B Q / K G \\
B Q / K G \\
B Q / K G \\
B Q / K G \\
B Q / K G \\
B Q / K G \\
B Q / K G \\
B Q / K G \\
B Q / K G \\
B Q / K G \\
B Q / K G \\
B Q / K G \\
B Q / K G \\
B Q / K G \\
B Q / K G \\
B Q / K G \\
B Q / K G\end{array}$ \\
\hline
\end{tabular}


68

Table B2 (continued)

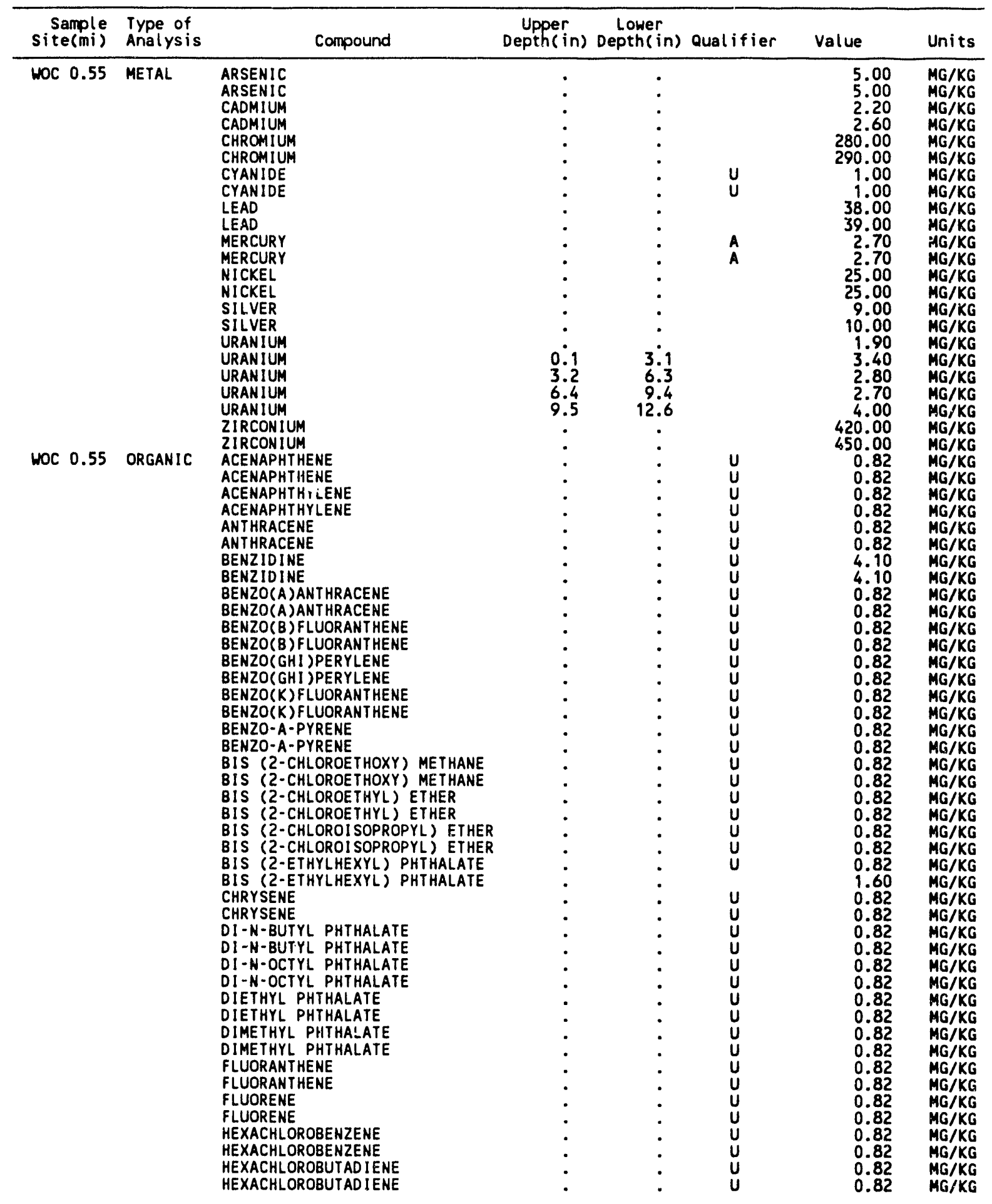


69

Table B2 (continued)

\begin{tabular}{|c|c|c|c|c|c|c|c|}
\hline $\begin{array}{r}\text { Sample } \\
\text { Site(mi) }\end{array}$ & $\begin{array}{l}\text { Type of } \\
\text { Analysis }\end{array}$ & Compound & $\begin{array}{c}\text { Upper } \\
\text { Depth(in) }\end{array}$ & $\begin{array}{l}\text { Lower } \\
\text { Depth(in) }\end{array}$ & Qualifier & Value & Units \\
\hline WOC 0.55 & ORGANIC & 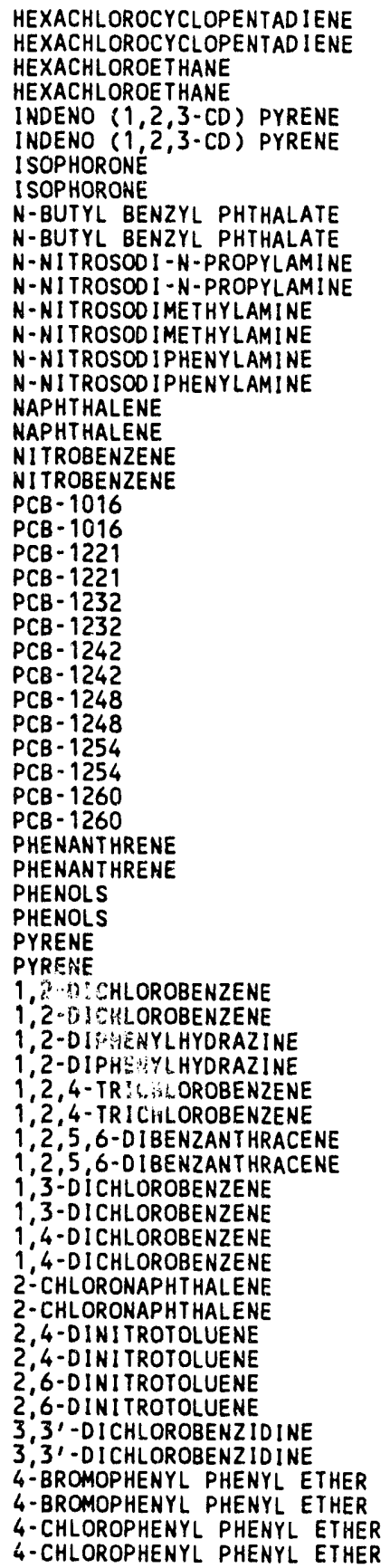 & $\begin{array}{l}: \\
: \\
: \\
: \\
: \\
: \\
: \\
: \\
: \\
: \\
: \\
: \\
: \\
: \\
: \\
: \\
: \\
: \\
: \\
: \\
: \\
: \\
: \\
: \\
: \\
: \\
: \\
: \\
: \\
: \\
: \\
: \\
: \\
: \\
: \\
: \\
: \\
: \\
: \\
: \\
: \\
: \\
: \\
: \\
: \\
: \\
: \\
:\end{array}$ & $\begin{array}{l}: \\
: \\
: \\
: \\
: \\
: \\
: \\
: \\
: \\
: \\
: \\
: \\
: \\
: \\
: \\
: \\
: \\
: \\
: \\
: \\
: \\
: \\
: \\
: \\
: \\
: \\
: \\
: \\
: \\
: \\
: \\
: \\
: \\
: \\
: \\
: \\
: \\
:\end{array}$ & 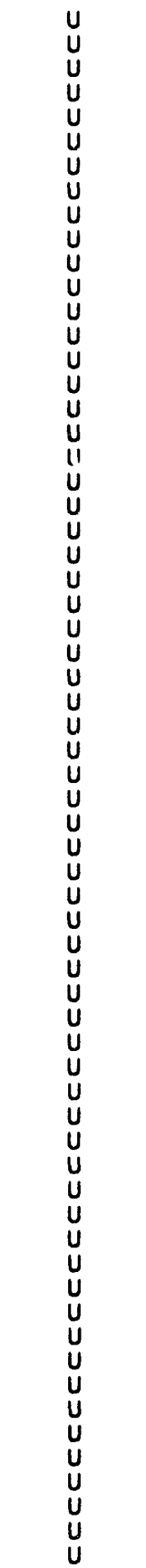 & $\begin{array}{l}0.82 \\
0.82 \\
0.82 \\
0.82 \\
0.82 \\
0.82 \\
0.82 \\
0.82 \\
0.82 \\
0.82 \\
0.82 \\
0.82 \\
0.82 \\
0.82 \\
0.82 \\
0.82 \\
0.82 \\
0.82 \\
0.82 \\
0.82 \\
0.10 \\
0.10 \\
0.10 \\
0.10 \\
0.10 \\
0.10 \\
0.10 \\
0.10 \\
0.10 \\
0.10 \\
0.10 \\
0.10 \\
0.10 \\
0.10 \\
0.82 \\
0.82 \\
0.40 \\
0.40 \\
0.82 \\
0.82 \\
0.82 \\
0.82 \\
0.82 \\
0.82 \\
0.82 \\
0.82 \\
0.82 \\
0.82 \\
0.82 \\
0.82 \\
0.82 \\
0.82 \\
0.82 \\
0.82 \\
0.82 \\
0.82 \\
0.82 \\
0.82 \\
2.10 \\
2.10 \\
0.82 \\
0.82 \\
0.82 \\
0.82\end{array}$ & $\begin{array}{l}M G / K G \\
M G / K G \\
M G / K G \\
M G / K G \\
M G / K G \\
M G / K G \\
M G / K G \\
M G / K G \\
M G / K G \\
M G / K G \\
M G / K G \\
M G / K G \\
M G / K G \\
M G / K G \\
M G / K G \\
M G / K G \\
M G / K G \\
M G / K G \\
M G / K G \\
M G / K G \\
M G / K G \\
M G / K G \\
M G / K G \\
M G / K G \\
M G / K G \\
M G / K G \\
M G / K G \\
M G / K G \\
M G / K G \\
M G / K G \\
M G / K G \\
M G / K G \\
M G / K G \\
M G / K G \\
M G / K G \\
M G / K G \\
M G / K G \\
M G / K G \\
M G / K G \\
M G / K G \\
M G / K G \\
M G / K G \\
M G / K G \\
M G / K G \\
M G / K G \\
M G / K G \\
M G / K G \\
M G / K G \\
M G / K G \\
M G / K G \\
M G / K G \\
M G / K G \\
M G / K G \\
M G / K G \\
M G / K G \\
M G / K G \\
M G / K G \\
M G / K G \\
M G / K G \\
M G / K G \\
M G / K G \\
M G / K G \\
M G / K G \\
M G / K G\end{array}$ \\
\hline
\end{tabular}


70

Table B2 (continued)

\begin{tabular}{|c|c|c|c|c|c|c|c|c|}
\hline $\begin{array}{c}\text { Sample } \\
\text { site(mi) }\end{array}$ & $\begin{array}{l}\text { Type of } \\
\text { Analys is }\end{array}$ & & Compound & $\begin{array}{l}\text { Upper } \\
\text { Depth(in) }\end{array}$ & $\begin{array}{l}\text { Lower } \\
\text { Depth(in) }\end{array}$ & Qualifier & Value & Units \\
\hline HOC 0.55 & $\begin{array}{l}\text { RADIO- } \\
\text { NUCLIDES }\end{array}$ & $\begin{array}{l}\text { AC- }-228 \\
A C-228 \\
A C-228 \\
A M-241 \\
A M-241 \\
A M-241 \\
A M-241 \\
A M-241 \\
A M-241 \\
B 1-214 \\
B I-214 \\
B I-214 \\
C O-60 \\
C O-60 \\
C O-60 \\
C O-60 \\
C O-60 \\
C S-134 \\
C S-134 \\
C S-134 \\
C S-134 \\
C S-134 \\
C S-134 \\
C S-137 \\
C S-137 \\
C S-137 \\
C S-137 \\
C S-137 \\
C M-244 \\
C M-244 \\
C M-244 \\
C M-244 \\
E U-152 \\
E U-152 \\
E U-152 \\
E U-152 \\
E U-154 \\
E U-154 \\
E U-154 \\
E U-154 \\
E U-154 \\
P B-212 \\
P B-212 \\
P B-212 \\
P B-212 \\
P B-212 \\
P B-214 \\
P B-214 \\
P U-238 \\
P U-238 \\
P U-238 \\
P U-238 \\
P U-239 \\
P U-239 \\
P U-239 \\
P U-239 \\
S R-89 \\
S R-89 \\
S R-89 \\
S R-89 \\
S R-89 \\
S R-90 \\
S R-90 \\
S R-90 \\
S R-90 \\
S R-90 \\
T H-234 \\
T L-208 \\
T L-208\end{array}$ & & $\begin{array}{l}3.2 \\
6.4 \\
9.5 \\
0.1 \\
3.2 \\
6.4 \\
9.5 \\
0.4 \\
9.5 \\
0.1 \\
3.2 \\
6.4 \\
9.5 \\
0 \\
0.1 \\
0.1 \\
3.2 \\
3.2 \\
0.1 \\
3.2 \\
6.4 \\
9.5 \\
0.1 \\
3.2 \\
6.4 \\
9.5 \\
0.1 \\
3.2 \\
6.4 \\
0.1 \\
3.2 \\
6.4 \\
9.5 \\
0.1 \\
3.2 \\
6.4 \\
9.5 \\
6.4 \\
9.5 \\
0.9 \\
3.2 \\
6.4 \\
9.5 \\
0.1 \\
3.2 \\
6.4 \\
9.5 \\
0.1 \\
3.2 \\
6.4 \\
9.5 \\
0.1 \\
3.2 \\
6.4 \\
9.5 \\
9.5 \\
9.5\end{array}$ & 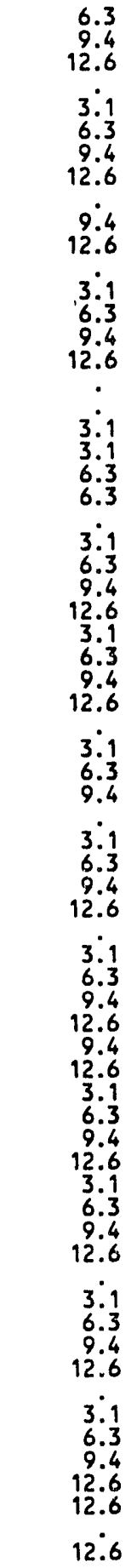 & $\begin{array}{l}M \\
M \\
M \\
M \\
M\end{array}$ & $\begin{array}{r}51.80 \\
40.70 \\
51.80 \\
148.00 \\
199.80 \\
133.20 \\
59.20 \\
24.79 \\
22.20 \\
40.70 \\
33.30 \\
4810.00 \\
5920.00 \\
4366.00 \\
1443.00 \\
592.00 \\
7.40 \\
44.40 \\
14.80 \\
48.10 \\
11.10 \\
33.30 \\
40145.00 \\
44807.00 \\
54057.00 \\
3733.00 \\
6956.00 \\
444.00 \\
236.80 \\
70.30 \\
43.66 \\
296.00 \\
329.30 \\
236.80 \\
88.80 \\
259.00 \\
329.30 \\
296.00 \\
133.20 \\
19.98 \\
40.70 \\
44.40 \\
44.40 \\
40.70 \\
44.40 \\
40.70 \\
40.70 \\
17.02 \\
13.32 \\
8.14 \\
1.33 \\
85.10 \\
88.80 \\
70.30 \\
13.32 \\
148.00 \\
11.10 \\
111.00 \\
37.00 \\
74.00 \\
629.00 \\
666.00 \\
444.00 \\
407.00 \\
222.00 \\
74.00 \\
14.80 \\
17.39\end{array}$ & $\begin{array}{l}B Q / K G \\
B Q / K G \\
B Q / K G \\
B Q / K G \\
B Q / K G \\
B Q / K G \\
B Q / K G \\
B Q / K G \\
B Q / K G \\
B Q / K G \\
B Q / K G \\
B Q / K G \\
B Q / K G \\
B Q / K G \\
B Q / K G \\
B Q / K G \\
B Q / K G \\
B Q / K G \\
B Q / K G \\
B Q / K G \\
B Q / K G \\
B Q / K G \\
B Q / K G \\
B Q / K G \\
B Q / K G \\
B Q / K G \\
B Q / K G \\
B Q / K G \\
B Q / K G \\
B Q / K G \\
B Q / K G \\
B Q / K G \\
B Q / K G \\
B Q / K G \\
B Q / K G \\
B Q / K G \\
B Q / K G \\
B Q / K G \\
B Q / K G \\
B Q / K G \\
B Q / K G \\
B Q / K G \\
B Q / K G \\
B Q / K G \\
B Q / K G \\
B Q / K G \\
B Q / K G \\
B Q / K G \\
B Q / K G \\
B Q / K G \\
B Q / K G \\
B Q / K G \\
B Q / K G \\
B Q / K G \\
B Q / K G \\
B Q / K G \\
B Q / K G \\
B Q / K G \\
B Q / K G \\
B Q / K G \\
B Q / K G \\
B Q / K G \\
B Q / K G \\
B Q / K G \\
B Q / K G \\
B Q / K G \\
B Q / K G \\
B Q / K G \\
\end{array}$ \\
\hline
\end{tabular}

$U, K=$ less than detection limit, $A=d u p l i c a t e$ samples averaged, $M=p r e s e n c e$ verified but not quantified Repeat of upper and lower depths for an analys is indicates dupl icate samples. 
Appendix C

CONLENTRATIONS OF INORGANIC AND ORGANIC CONTAMINANTS IN WHITE OAK CREEK EMBAYMENT CORE SAMPLES COLLECTED IN 1990 
Table C1. Sumbry of inorganic and organic contaminant concentrations in thite Oak Creek Embayment core samples collected in $1990^{\circ}$.

\begin{tabular}{|c|c|c|c|c|c|c|c|c|c|}
\hline $\begin{array}{l}\text { Analys is } \\
\text { Type }\end{array}$ & Compound & Number & $\min _{\text {Qual }}$ & $\begin{array}{l}\text { Minimum } \\
\text { Value }\end{array}$ & $\begin{array}{l}\text { Max } \\
\text { Qual }\end{array}$ & $\begin{array}{l}\text { Maximun } \\
\text { Value }\end{array}$ & $\begin{array}{l}\text { Mean } \\
\text { Volue }\end{array}$ & $\begin{array}{l}\text { Standard } \\
\text { Deviation }\end{array}$ & Units \\
\hline METALS & $\begin{array}{l}\text { ANTIMONY } \\
\text { ARSENIC } \\
\text { BERYLLIUM } \\
\text { CADMIUM } \\
\text { CHROMIIUM } \\
\text { COPPER } \\
\text { LEAD } \\
\text { MERCURY } \\
\text { NICKEL } \\
\text { SELENIU } \\
\text { SILVER } \\
\text { THALLIUH } \\
\text { ZINC }\end{array}$ & $\begin{array}{l}11 \\
23 \\
23 \\
23 \\
23 \\
23 \\
23 \\
18 \\
23 \\
23 \\
23 \\
22 \\
23\end{array}$ & $\begin{array}{l}U J \\
J \\
V / V \\
V / V \\
V / V \\
V / V \\
J \\
U \\
V / V \\
U J \\
U \\
U \\
V / V\end{array}$ & $\begin{array}{r}8.600 \\
0.030 \\
0.730 \\
1.000 \\
24.000 \\
13.000 \\
13.900 \\
0.120 \\
17.900 \\
0.000 \\
2.900 \\
0.280 \\
51.600\end{array}$ & $\begin{array}{l}J \\
J \\
V / V \\
V / V \\
V / V \\
V / V \\
V / V \\
J \\
V / V \\
U J \\
V / V \\
V / V \\
V / V\end{array}$ & $\begin{array}{r}14.40 \\
7.60 \\
2.80 \\
4.40 \\
101.00 \\
43.20 \\
138.00 \\
360.00 \\
30.10 \\
0.70 \\
18.40 \\
0.78 \\
123.00\end{array}$ & $\begin{array}{r}9.71 \\
4.09 \\
1.57 \\
2.51 \\
57.08 \\
25.32 \\
66.11 \\
81.37 \\
23.53 \\
0.53 \\
8.41 \\
0.63 \\
80.25\end{array}$ & $\begin{array}{r}1.67 \\
1.67 \\
0.77 \\
1.04 \\
32.27 \\
12.29 \\
45.86 \\
96.24 \\
3.27 \\
0.23 \\
6.75 \\
0.10 \\
24.95\end{array}$ & $\begin{array}{l}M G / K G \\
M G / K G \\
M G / K G \\
M G / K G \\
M G / K G \\
M G / K G \\
M G / K G \\
M G / K G \\
M G / K G \\
M G / K G \\
M G / K G \\
M G / K G \\
M G / K G\end{array}$ \\
\hline ORGANICS & 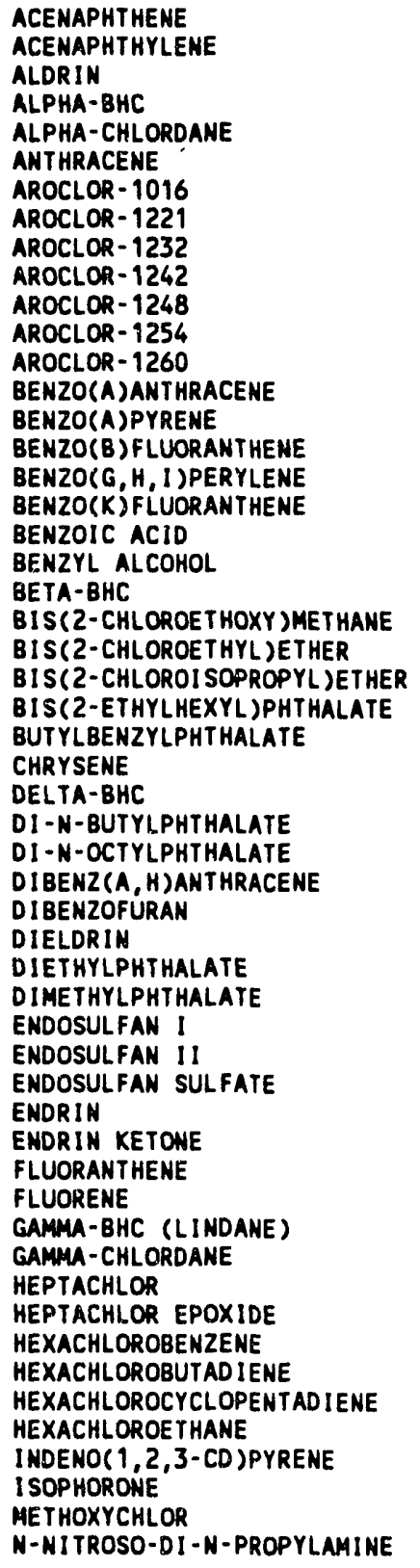 & $\begin{array}{l}26 \\
26 \\
25 \\
25 \\
25 \\
26 \\
25 \\
25 \\
25 \\
25 \\
25 \\
25 \\
25 \\
26 \\
26 \\
26 \\
26 \\
26 \\
26 \\
26 \\
25 \\
26 \\
26 \\
26 \\
26 \\
26 \\
26 \\
25 \\
26 \\
26 \\
26 \\
26 \\
25 \\
26 \\
26 \\
25 \\
25 \\
25 \\
25 \\
25 \\
26 \\
26 \\
25 \\
25 \\
25 \\
25 \\
26 \\
26 \\
26 \\
26 \\
26 \\
26 \\
25 \\
26\end{array}$ & 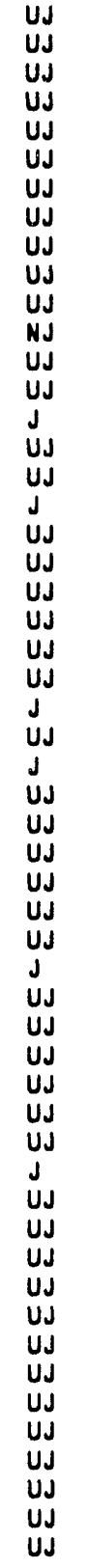 & $\begin{array}{l}0.920 \\
0.920 \\
0.013 \\
0.013 \\
0.110 \\
0.920 \\
0.110 \\
0.110 \\
0.110 \\
0.110 \\
0.110 \\
0.044 \\
0.220 \\
0.920 \\
0.320 \\
0.920 \\
0.920 \\
0.110 \\
4.500 \\
0.920 \\
0.013 \\
0.920 \\
0.920 \\
0.920 \\
0.330 \\
0.920 \\
0.120 \\
0.013 \\
0.920 \\
0.920 \\
0.920 \\
0.920 \\
0.022 \\
0.140 \\
0.920 \\
0.013 \\
0.022 \\
0.022 \\
0.022 \\
0.022 \\
0.140 \\
0.920 \\
0.013 \\
0.110 \\
0.013 \\
0.013 \\
0.920 \\
0.920 \\
0.920 \\
0.920 \\
0.920 \\
0.920 \\
0.110 \\
0.920\end{array}$ & 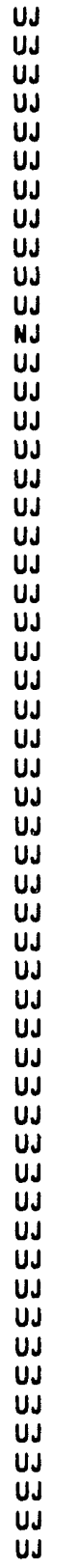 & $\begin{array}{l}6.10 \\
6.10 \\
0.15 \\
0.15 \\
1.50 \\
6.10 \\
1.50 \\
1.50 \\
1.50 \\
1.50 \\
1.50 \\
4.70 \\
2.90 \\
6.10 \\
6.10 \\
6.10 \\
6.10 \\
6.10 \\
29.00 \\
6.10 \\
0.15 \\
6.10 \\
6.10 \\
6.10 \\
6.10 \\
6.10 \\
6.10 \\
0.15 \\
6.10 \\
6.10 \\
6.10 \\
6.10 \\
0.29 \\
6.10 \\
6.10 \\
0.15 \\
0.29 \\
0.29 \\
0.29 \\
0.29 \\
6.10 \\
6.10 \\
0.15 \\
1.50 \\
0.15 \\
0.15 \\
9.50 \\
6.10 \\
6.10 \\
6.10 \\
6.10 \\
6.10 \\
1.50 \\
6.10\end{array}$ & $\begin{array}{l}2.82 \\
2.82 \\
0.12 \\
0.12 \\
1.22 \\
2.82 \\
1.22 \\
1.22 \\
1.22 \\
1.22 \\
1.22 \\
1.82 \\
2.45 \\
2.82 \\
2.43 \\
2.82 \\
2.82 \\
2.79 \\
13.73 \\
2.82 \\
0.12 \\
2.82 \\
2.82 \\
2.82 \\
2.56 \\
2.82 \\
2.65 \\
0.12 \\
2.82 \\
2.82 \\
2.82 \\
2.82 \\
0.25 \\
2.79 \\
2.82 \\
0.12 \\
0.25 \\
0.25 \\
0.25 \\
0.25 \\
2.66 \\
2.82 \\
0.12 \\
1.22 \\
0.12 \\
0.12 \\
3.11 \\
2.82 \\
2.82 \\
2.82 \\
2.82 \\
2.82 \\
1.22 \\
2.82\end{array}$ & $\begin{array}{c}2.10 \\
2.10 \\
0.03 \\
0.03 \\
0.26 \\
2.10 \\
0.26 \\
0.26 \\
0.26 \\
0.26 \\
0.26 \\
1.43 \\
0.51 \\
2.10 \\
2.37 \\
2.10 \\
2.10 \\
2.14 \\
10.17 \\
2.10 \\
0.03 \\
2.10 \\
2.10 \\
2.10 \\
2.12 \\
2.10 \\
2.28 \\
0.03 \\
2.10 \\
2.10 \\
2.10 \\
2.10 \\
0.05 \\
2.14 \\
2.10 \\
0.03 \\
0.05 \\
0.05 \\
0.05 \\
0.05 \\
2.27 \\
2.10 \\
0.03 \\
0.26 \\
0.03 \\
0.03 \\
2.47 \\
2.10 \\
2.10 \\
2.10 \\
2.10 \\
2.10 \\
0.26 \\
2.10\end{array}$ & $\begin{array}{l}M G / K G \\
M G / K G \\
M G / K G \\
M G / K G \\
M G / K G \\
M G / K G \\
M G / K G \\
M G / K G \\
M G / K G \\
M G / K G \\
M G / K G \\
M G / K G \\
M G / K G \\
M G / K G \\
M G / K G \\
M G / K G \\
M G / K G \\
M G / K G \\
M G / K G \\
M G / K G \\
M G / K G \\
M G / K G \\
M G / K G \\
M G / K G \\
M G / K G \\
M G / K G \\
M G / K G \\
M G / K G \\
M G / K G \\
M G / K G \\
M G / K G \\
M G / K G \\
M G / K G \\
M G / K G \\
M G / K G \\
M G / K G \\
M G / K G \\
M G / K G \\
M G / K G \\
M G / K G \\
M G / K G \\
M G / K G \\
M G / K G \\
M G / K G \\
M G / K G \\
M G / K G \\
M G / K G \\
M G / K G \\
M G / K G \\
M G / K G \\
M G / K G \\
M G / K G \\
M G / K G \\
M G / K G\end{array}$ \\
\hline
\end{tabular}


Table C1 (cont inued)

\begin{tabular}{|c|c|c|c|c|c|c|c|c|c|}
\hline $\begin{array}{c}\text { Analysis } \\
\text { Type }\end{array}$ & Compound & Number & $\begin{array}{l}\text { Min } \\
\text { Qual }\end{array}$ & $\begin{array}{l}\text { Minimum } \\
\text { Value }\end{array}$ & $\begin{array}{l}\text { Max } \\
\text { Qual }\end{array}$ & $\begin{array}{l}\text { Maximum } \\
\text { Value }\end{array}$ & $\begin{array}{l}\text { Mean } \\
\text { Value }\end{array}$ & $\begin{array}{l}\text { Standard } \\
\text { Deviation }\end{array}$ & Units \\
\hline ORGANICS & 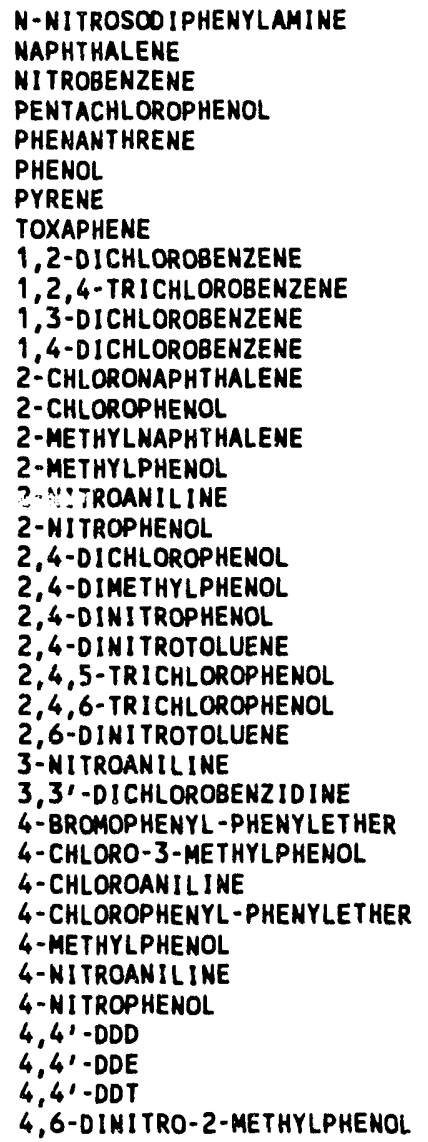 & $\begin{array}{l}26 \\
26 \\
26 \\
26 \\
26 \\
26 \\
26 \\
25 \\
26 \\
26 \\
26 \\
26 \\
26 \\
26 \\
26 \\
26 \\
26 \\
26 \\
26 \\
26 \\
26 \\
26 \\
26 \\
26 \\
26 \\
26 \\
26 \\
26 \\
26 \\
26 \\
26 \\
26 \\
26 \\
26 \\
25 \\
25 \\
25 \\
26\end{array}$ & 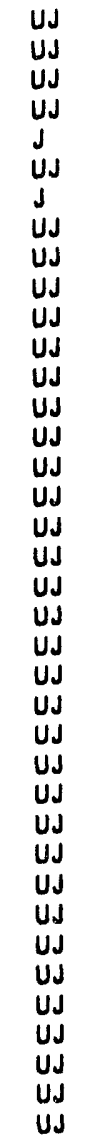 & $\begin{array}{l}0.920 \\
0.920 \\
0.920 \\
4.500 \\
0.140 \\
0.920 \\
0.100 \\
0.220 \\
0.920 \\
0.920 \\
0.920 \\
0.920 \\
0.920 \\
0.920 \\
0.920 \\
0.920 \\
4.500 \\
0.920 \\
0.920 \\
0.920 \\
4.500 \\
0.920 \\
4.500 \\
0.920 \\
0.920 \\
2.900 \\
1.800 \\
0.920 \\
0.920 \\
0.920 \\
0.920 \\
0.920 \\
4.500 \\
4.500 \\
0.022 \\
0.022 \\
0.022 \\
4.500\end{array}$ & $\begin{array}{l}\text { UJ } \\
U J J \\
U J \\
U J J \\
U J J \\
U J J \\
U J J \\
U J \\
U J \\
U J \\
U J \\
U J \\
U J \\
U J \\
U J J \\
U J J \\
U J \\
U J \\
U J \\
U J \\
U J \\
U J \\
U J \\
U J \\
U J \\
U J \\
U J \\
U J \\
U J \\
U J \\
U J \\
U J \\
U J \\
U J \\
U J \\
U J \\
U J \\
U J \\
U J \\
U J \\
U J \\
U J \\
U J\end{array}$ & $\begin{array}{r}8.50 \\
6.10 \\
6.10 \\
29.00 \\
6.10 \\
6.10 \\
6.10 \\
2.90 \\
6.10 \\
6.10 \\
6.10 \\
6.10 \\
6.10 \\
6.10 \\
6.10 \\
6.10 \\
29.00 \\
6.10 \\
6.10 \\
6.10 \\
29.00 \\
6.10 \\
29.00 \\
6.10 \\
6.10 \\
29.00 \\
12.00 \\
9.50 \\
6.10 \\
6.10 \\
6.10 \\
6.10 \\
29.00 \\
29.00 \\
0.29 \\
0.29 \\
0.29 \\
29.00\end{array}$ & $\begin{array}{r}3.11 \\
2.82 \\
2.82 \\
13.73 \\
2.66 \\
2.82 \\
2.59 \\
2.45 \\
2.82 \\
2.82 \\
2.82 \\
2.82 \\
2.82 \\
2.82 \\
2.82 \\
2.82 \\
13.73 \\
2.82 \\
2.82 \\
2.82 \\
13.73 \\
2.82 \\
13.73 \\
2.82 \\
2.82 \\
12.73 \\
5.67 \\
3.11 \\
2.82 \\
2.82 \\
2.82 \\
2.82 \\
13.73 \\
13.73 \\
0.25 \\
0.25 \\
0.25 \\
13.73\end{array}$ & $\begin{array}{r}2.47 \\
2.10 \\
2.10 \\
10.17 \\
2.27 \\
2.10 \\
2.33 \\
0.51 \\
2.10 \\
2.10 \\
2.10 \\
2.10 \\
2.10 \\
2.10 \\
2.10 \\
2.10 \\
10.17 \\
2.10 \\
2.10 \\
2.10 \\
10.17 \\
2.10 \\
10.17 \\
2.10 \\
2.10 \\
9.89 \\
4.21 \\
2.47 \\
2.10 \\
2.10 \\
2.10 \\
2.10 \\
10.17 \\
10.17 \\
0.05 \\
0.05 \\
0.05 \\
10.17\end{array}$ & $\begin{array}{l}M G / K G \\
M G / K G \\
M G / K G \\
M G / K G \\
M G / K G \\
M G / K G \\
M G / K G \\
M G / K G \\
M G / K G \\
M G / K G \\
M G / K G \\
M G / K G \\
M G / K G \\
M G / K G \\
M G / K G \\
M G / K G \\
M G / K G \\
M G / K G \\
M G / K G \\
M G / K G \\
M G / K G \\
M G / K G \\
M G / K G \\
M G / K G \\
M G / K G \\
M G / K G \\
M G / K G \\
M G / K G \\
M G / K G \\
M G / K G \\
M G / K G \\
M G / K G \\
M G / K G \\
M G / K G \\
M G / K G \\
M G / K G \\
M G / K G \\
M G / K G\end{array}$ \\
\hline
\end{tabular}

"Core collected for metal analysis: $9400 \mathrm{~T}$

core collected for organic analysis: 107000

'QUALIFIER COOES:

$U=$ Compound was analyzed for but not detected.

$J=$ Indicates an estimated value.

$U J=$ Compound was analyzed for but not detected and quantitation limit is an estimated value.

$N J=$ Tentative compound identification only and estimated concentration. No second colum confirmation of pesticides.

$V / V=$ Indicates that the result has been reviewed and is a valid result. 
Table C2. Sumary of inorganic and organic contaminant concentrations in WOCE core samples collected after July $1990^{\circ}$ 。

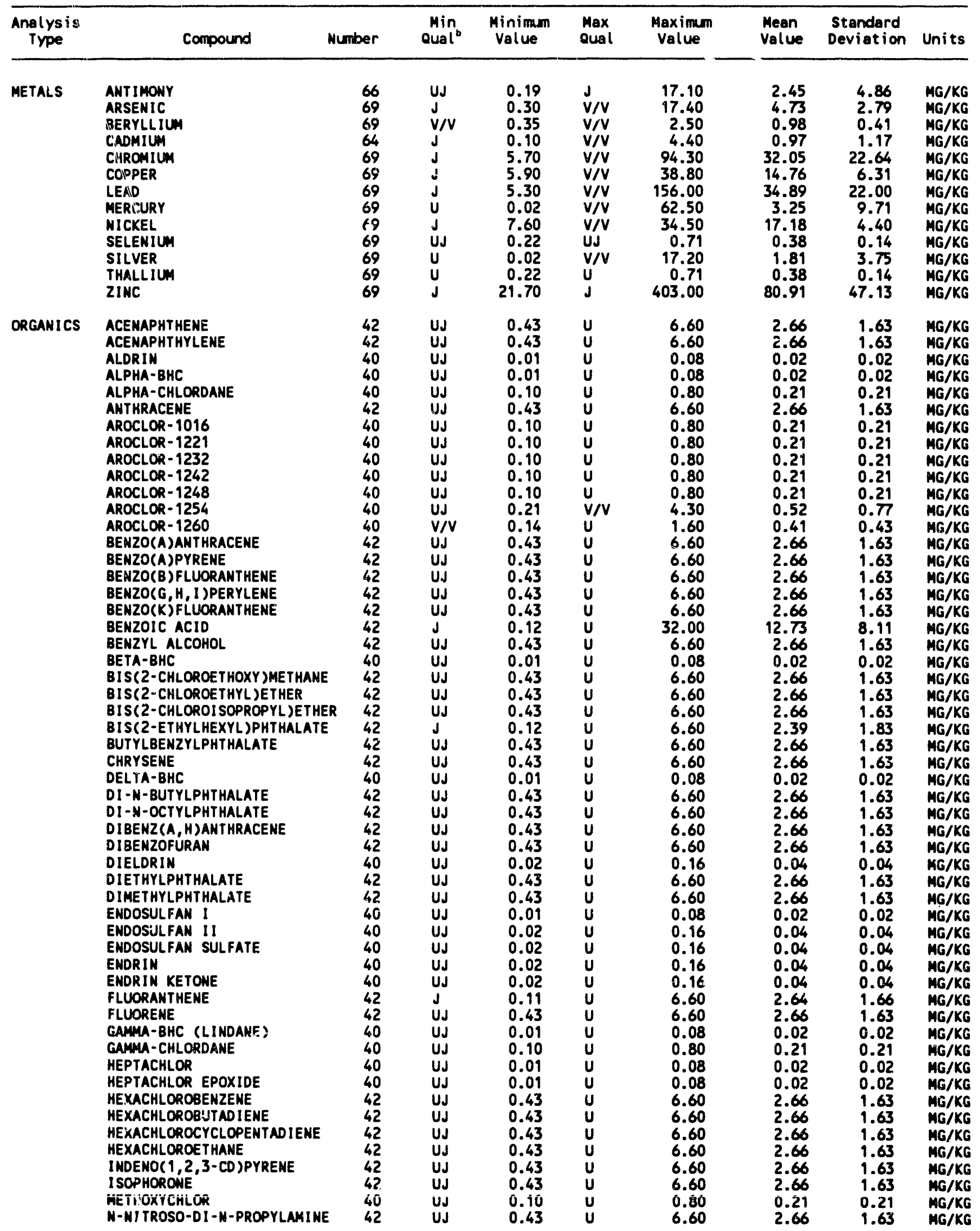


Table 02 (continued)

\begin{tabular}{|c|c|c|c|c|c|c|c|c|c|}
\hline $\begin{array}{c}\text { Analys is } \\
\text { Type }\end{array}$ & Compound & Number & $\begin{array}{l}\text { Min } \\
\text { Qual }\end{array}$ & $\begin{array}{l}\text { Minimum } \\
\text { Value }\end{array}$ & $\begin{array}{l}\text { Max } \\
\text { Qual }\end{array}$ & $\begin{array}{l}\text { Maximum } \\
\text { Value }\end{array}$ & $\begin{array}{l}\text { Mean } \\
\text { Volue }\end{array}$ & $\begin{array}{l}\text { Standard } \\
\text { Deviation }\end{array}$ & Units \\
\hline ORGANICS & 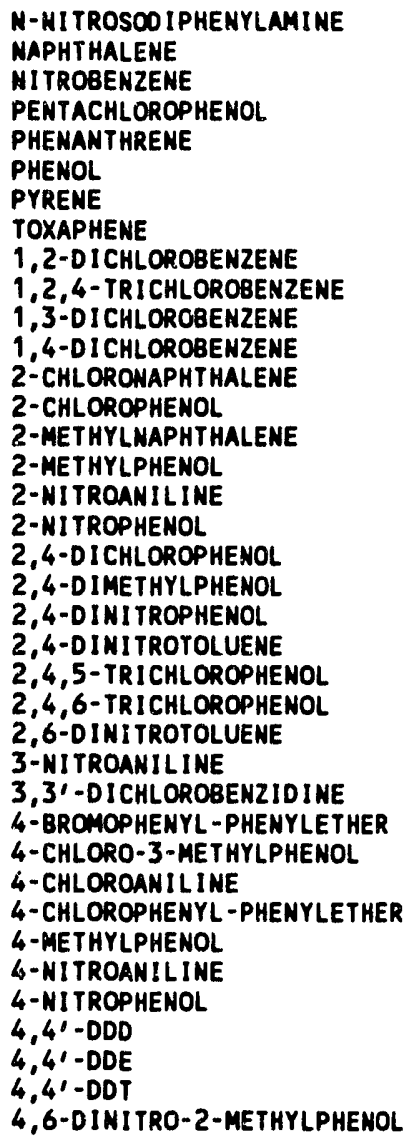 & $\begin{array}{l}42 \\
42 \\
42 \\
42 \\
42 \\
42 \\
42 \\
40 \\
42 \\
42 \\
42 \\
42 \\
42 \\
42 \\
42 \\
42 \\
42 \\
42 \\
42 \\
42 \\
42 \\
42 \\
42 \\
42 \\
42 \\
42 \\
42 \\
42 \\
42 \\
42 \\
42 \\
42 \\
42 \\
42 \\
40 \\
40 \\
40 \\
42\end{array}$ & $\begin{array}{l}\text { UJ } \\
\text { UJ } \\
\text { UJ } \\
J \\
\text { UJ } \\
J \\
\text { UJ } \\
\text { UJ } \\
\text { UJ } \\
\text { UJ } \\
\text { UJ } \\
\text { UJ } \\
\text { UJ } \\
\text { UJ } \\
\text { UJ } \\
\text { UJ } \\
\text { UJ } \\
\text { UJ } \\
\text { UJ } \\
\text { UJ } \\
\text { UJ } \\
\text { UJ } \\
\text { UJ } \\
\text { UJ } \\
\text { UJ } \\
\text { UJ } \\
\text { UJ } \\
\text { UJ } \\
\text { UJ } \\
\text { UJ } \\
\text { UJ } \\
\text { UJ } \\
\text { UJ } \\
\text { UJ } \\
\text { UJ } \\
\text { UJ }\end{array}$ & $\begin{array}{l}0.43 \\
0.43 \\
0.43 \\
2.10 \\
0.34 \\
0.43 \\
0.11 \\
0.21 \\
0.43 \\
0.43 \\
0.43 \\
0.43 \\
0.43 \\
0.43 \\
0.43 \\
0.43 \\
2.10 \\
0.43 \\
0.43 \\
0.43 \\
2.10 \\
0.43 \\
2.10 \\
0.43 \\
0.43 \\
2.10 \\
0.86 \\
0.43 \\
0.43 \\
0.43 \\
0.43 \\
0.43 \\
2.10 \\
2.10 \\
0.02 \\
0.02 \\
0.02 \\
2.10\end{array}$ & $\begin{array}{l}U \\
U \\
U \\
U \\
U \\
U \\
U \\
U \\
U \\
U \\
U \\
U \\
U \\
U \\
U \\
U \\
U \\
U \\
U \\
U \\
U \\
U \\
U \\
U \\
U \\
U \\
U \\
U \\
U \\
U \\
U \\
U \\
U \\
U \\
U \\
U \\
U \\
U\end{array}$ & $\begin{array}{r}6.60 \\
6.60 \\
6.60 \\
32.00 \\
6.60 \\
6.60 \\
6.60 \\
1.60 \\
6.60 \\
6.60 \\
6.60 \\
6.60 \\
6.60 \\
6.60 \\
6.60 \\
6.60 \\
32.00 \\
6.60 \\
6.60 \\
6.60 \\
32.00 \\
6.60 \\
32.00 \\
6.60 \\
6.60 \\
32.00 \\
13.00 \\
6.60 \\
6.60 \\
6.60 \\
6.60 \\
6.60 \\
32.00 \\
32.00 \\
0.16 \\
0.16 \\
0.16 \\
32.00\end{array}$ & $\begin{array}{r}2.66 \\
2.66 \\
2.66 \\
12.85 \\
2.61 \\
2.66 \\
2.56 \\
0.41 \\
2.66 \\
2.66 \\
2.66 \\
2.66 \\
2.66 \\
2.66 \\
2.66 \\
2.66 \\
12.86 \\
2.66 \\
2.66 \\
2.66 \\
12.86 \\
2.85 \\
12.86 \\
2.85 \\
2.66 \\
12.86 \\
5.35 \\
2.66 \\
2.66 \\
2.66 \\
2.66 \\
2.66 \\
12.86 \\
12.85 \\
0.05 \\
0.04 \\
0.04 \\
12.85\end{array}$ & $\begin{array}{l}1.63 \\
1.63 \\
1.63 \\
7.96 \\
1.67 \\
1.63 \\
1.70 \\
0.43 \\
1.63 \\
1.63 \\
1.63 \\
1.63 \\
1.63 \\
1.63 \\
1.63 \\
1.63 \\
7.96 \\
1.63 \\
1.63 \\
1.63 \\
7.96 \\
1.63 \\
7.96 \\
1.63 \\
1.63 \\
7.96 \\
3.25 \\
1.63 \\
1.63 \\
1.63 \\
1.63 \\
1.63 \\
7.96 \\
7.96 \\
0.06 \\
0.04 \\
0.04 \\
7.96\end{array}$ & $\begin{array}{l}M G / K G \\
M G / K G \\
M G / K G \\
M G / K G \\
M G / K G \\
M G / K G \\
M G / K G \\
M G / K G \\
M G / K G \\
M G / K G \\
M G / K G \\
M G / K G \\
M G / K G \\
M G / K G \\
M G / K G \\
M G / K G \\
M G / K G \\
M G / K G \\
M G / K G \\
M G / K G \\
M G / K G \\
M G / K G \\
M G / K G \\
M G / K G \\
M G / K G \\
M G / K G \\
M G / K G \\
M G / K G \\
M G / K G \\
M G / K G \\
M G / K G \\
M G / K G \\
M G / K G \\
M G / K G \\
M G / K G \\
M G / K G \\
M G / K G \\
M G / K G\end{array}$ \\
\hline
\end{tabular}

'Cores collected for metal analysis: 54100T, 54300T, 63500T

Cores collected for organic analysis: 553000,555000

'QUALIFIER COOES:

$U=$ Compound was analyzed for but not detected.

$J=$ Indicates an estimated value.

$U J=$ Compound was analyzed for but not detected and quantitation limit is an estimated value.

NJ = Tentative compound identification only and estimated concentration. No second colum confirmation of pesticides.

$V / V=$ Indicates that the result has been reviewed and is a valid result. 
Appendix D

CONCENTRATIONS OF RADIONUCLIDES IN WHITE OAK CREEK EMBAYMENT

SURFACE SEDIMENT SAMPLES

COLLECTED IN 1990 
Table D1. Sumary of radionuclide concentrations in WOCE grab samples

\begin{tabular}{|c|c|c|c|c|c|c|c|c|c|}
\hline $\begin{array}{l}\text { Analysi } \\
\text { Type }\end{array}$ & $\begin{array}{l}\text { is } \\
\text { Compound }\end{array}$ & Number & $\begin{array}{l}\text { Minimum } \\
\text { Qualifier" }\end{array}$ & $\begin{array}{l}\text { Minimum } \\
\text { Value }\end{array}$ & $\begin{array}{l}\text { Maximum } \\
\text { Qualifier }\end{array}$ & $\begin{array}{l}\text { Maximum } \\
\text { Value }\end{array}$ & $\begin{array}{l}\text { Mean } \\
\text { Value }\end{array}$ & $\begin{array}{l}\text { Standard } \\
\text { Deviation }\end{array}$ & Units \\
\hline RAD & $\begin{array}{l}C O-60 \\
C S-137 \\
E U-152 \\
E U-154\end{array}$ & $\begin{array}{l}75 \\
77 \\
40 \\
39\end{array}$ & $\begin{array}{l}\text { J } \\
\text { V/V } \\
\text { NOTV } \\
\text { NOTV }\end{array}$ & $\begin{array}{r}10.68 \\
151.22 \\
36.32 \\
12.77\end{array}$ & $\begin{array}{l}\text { J } \\
\text { NOTV } \\
\text { NOTV } \\
\text { NOTV }\end{array}$ & $\begin{array}{r}6080.06 \\
1129569.94 \\
1072.93 \\
309.80\end{array}$ & $\begin{array}{r}939.44 \\
100598.23 \\
237.58 \\
82.46\end{array}$ & $\begin{array}{r}1029.99 \\
188749.70 \\
200.18 \\
57.42\end{array}$ & $\begin{array}{l}B Q / K G \\
B Q / K G \\
B Q / K G \\
B Q / K G\end{array}$ \\
\hline
\end{tabular}

"QUALIFIER COOES:

$U=$ Compound was analyzed for but not detected.

$J=$ Indicates on estimated value.

UJ $=$ Compound was analyzed for but not detected and quantitation limit is an estimated value.

$H J=$ Tentative compound identification only ard estimated concentration. No second colum confirmation of pesticides.

$V / V=$ Indicates that the result has been reviewed and is a valid result .

NOTV = Result has not been validated. Value corroborated by historical data and/or validated results for co-located samples and should be considered a reliable estimate. 
80

Table 02. Radionuclide concentrations in WOCE grab samples

\begin{tabular}{|c|c|c|c|c|c|}
\hline $\begin{array}{l}\text { Sample } \\
10\end{array}$ & $\begin{array}{c}\text { Co-60 } \\
\text { Qualifier" }\end{array}$ & $\begin{array}{l}\text { Co- } 60 \\
\text { Value }\end{array}$ & $\begin{array}{c}\text { CS-137 } \\
\text { Qualifier }\end{array}$ & $\begin{array}{l}\text { CS-137 } \\
\text { Value }\end{array}$ & Units \\
\hline $\begin{array}{l}30200 B \\
30300 B \\
30400 B \\
30500 B \\
30600 B \\
30700 B \\
30800 B \\
30900 B \\
31000 B \\
31100 B \\
31200 B \\
31300 B \\
31400 B \\
31500 B \\
31600 B \\
31700 B \\
31800 B \\
31900 B \\
32000 B \\
32100 B \\
32200 B \\
32300 B \\
32400 B \\
32500 B \\
32600 B \\
32700 B \\
32800 B \\
32900 B \\
33000 B \\
33100 B \\
33200 B \\
36900 B \\
37000 B \\
37100 B \\
37200 B \\
37300 B \\
37400 B \\
37500 B \\
37600 B \\
37700 B \\
37800 B \\
37900 B \\
38000 B \\
38100 B \\
38200 B \\
38300 B \\
38400 B \\
38500 B \\
38600 B \\
38700 B \\
38800 B \\
38900 B \\
39000 B \\
39100 B \\
39200 B \\
39300 B \\
39400 B \\
39500 B \\
39600 B \\
39700 B \\
39800 B \\
39900 B \\
40000 B \\
40100 B \\
40200 B \\
40300 B \\
40400 B \\
40500 B \\
40600 B\end{array}$ & $\begin{array}{l}J \\
U \\
J \\
J \\
J \\
J \\
J \\
J \\
J \\
J \\
J \\
J \\
J \\
J \\
J \\
J \\
J \\
\text { VIV } \\
J \\
J \\
J \\
J \\
J \\
J \\
J \\
J \\
J \\
J \\
J \\
U \\
J \\
J \\
\text { NOTV } \\
\text { NOTV } \\
\text { NOTV } \\
\text { NOTV } \\
\text { NOTV } \\
\text { NOTV } \\
\text { NOTV } \\
\text { NOTV } \\
\text { NOTV } \\
\text { NOTV } \\
\text { NOTV } \\
\text { NOTV } \\
\text { NOTV } \\
\text { NOTV } \\
\text { NOTV } \\
\text { NOTV } \\
\text { NOTV } \\
\text { NOTV } \\
\text { NOTV } \\
\text { NOTV } \\
\text { HOTV } \\
\text { HOTV } \\
\text { NOTV } \\
\text { NOTV } \\
\text { NOTV } \\
\text { NOTV } \\
\text { NOTV } \\
\text { NOTV } \\
\text { NOTV } \\
\text { NOTV } \\
\text { NOTV } \\
\text { NOTV } \\
\text { NOTV } \\
\text { NOTV } \\
\text { NOTV } \\
\text { NOTV } \\
\text { NOTV } \\
J\end{array}$ & 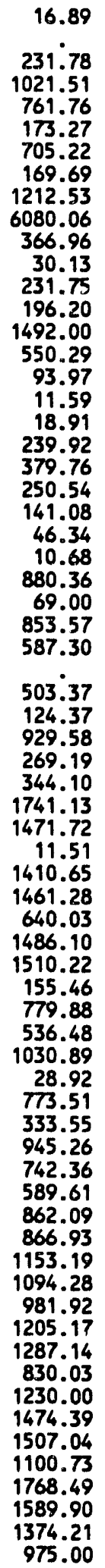 & 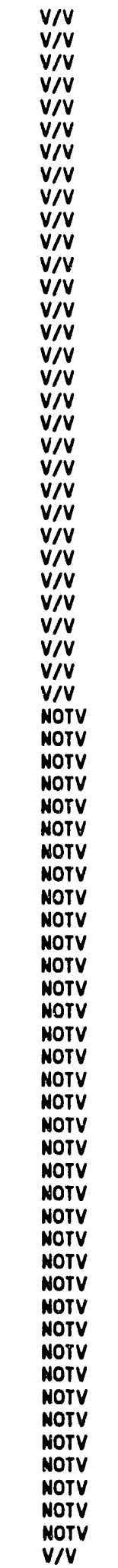 & $\begin{array}{r}631.59 \\
151.22 \\
49364.68 \\
444237.56 \\
285359.48 \\
9193.25 \\
270496.08 \\
8774.05 \\
193469.88 \\
587219.10 \\
22473.79 \\
1862.86 \\
15102.73 \\
10038.12 \\
793163.38 \\
33452.05 \\
8552.58 \\
594.44 \\
783.71 \\
15563.23 \\
82316.51 \\
4604.26 \\
6280.44 \\
1196.21 \\
6529.41 \\
95095.40 \\
3138.93 \\
131210.68 \\
79481.48 \\
238444.44 \\
264162.79 \\
3132.07 \\
1129569.94 \\
9810.06 \\
18870.39 \\
112169.20 \\
91289.96 \\
322.54 \\
76733.50 \\
96961.11 \\
8819.16 \\
79362.63 \\
97373.79 \\
5442.34 \\
27835.30 \\
20256.79 \\
55312.06 \\
908.66 \\
25770.28 \\
6602.58 \\
86609.54 \\
31796.73 \\
12582.06 \\
19209.01 \\
22642.64 \\
62956.20 \\
32556.73 \\
23550.50 \\
31716.81 \\
33202.49 \\
20655.22 \\
22824.09 \\
37125.88 \\
84629.47 \\
39687.96 \\
78017.14 \\
37835.54 \\
26992.28 \\
20471.92\end{array}$ & 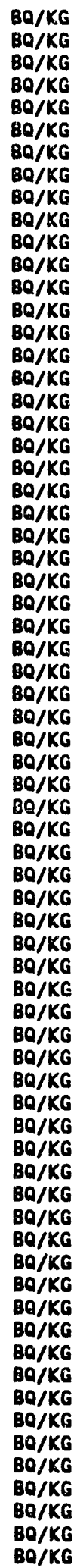 \\
\hline
\end{tabular}


81

Table D2 (continued)

\begin{tabular}{ccrccc}
\hline $\begin{array}{c}\text { Sample } \\
\text { ID }\end{array}$ & $\begin{array}{c}\text { CO-60 } \\
\text { Qualifier }\end{array}$ & $\begin{array}{c}\text { CO-60 } \\
\text { Value }\end{array}$ & $\begin{array}{c}\text { CS-137 } \\
\text { Qualifier }\end{array}$ & $\begin{array}{c}\text { CS-137 } \\
\text { Value }\end{array}$ & Units \\
\hline $40700 B$ & NOTV & 585.87 & NOTV & 15411.10 & BQ/KG \\
$40800 B$ & NOTV & 1337.26 & NOTV & 63555.83 & BQ/KG \\
$40900 B$ & NOTV & 1493.23 & NOTV & 34242.73 & BQ/KG \\
$42600 B$ & V/V & 5093.43 & V/V & 481761.26 & BQ/KG \\
$42800 B$ & V/V & 1067.34 & V/V & 91077.39 & BQ/KG \\
$59300 B$ & NOTV & 401.47 & NOTV & 16169.18 & BQ/KG \\
$59400 B$ & NOTV & 4182.09 & NOTV & 505474.42 & BQ/KG \\
$59600 B$ & NOTV & 2354.71 & NOTV & 283822.60 & BQ/KG \\
\hline
\end{tabular}

"QUALIFIER COOES:

$U=$ Compound was analyzed for but not detected.

$J=$ Indicates an est imated value.

UJ = Compound was analyzed for but not detected ano' quantitation limit is an estimated value.

NJ = Tentative compound identification only and estimsted concentration. No second colum confirmation of pesticides.

$V / V=$ Indicates that the result has been reviewed and is a valid result.

NOTV = Result has not been validated. Value corroborated by historical data and/or validated results for co-located samples and should be considered a reliable estimate. 
Table 03. Sumary of radionuclide concentrations in WOCE core samples

\begin{tabular}{|c|c|c|c|c|c|c|c|c|c|}
\hline $\begin{array}{l}\text { Analys is } \\
\text { Type }\end{array}$ & s compound & Number & $\begin{array}{l}\text { Minimum } \\
\text { Qualifier. }\end{array}$ & $\begin{array}{c}\text { Minimum } \\
\text { Value }\end{array}$ & $\begin{array}{l}\text { Maximum } \\
\text { oualifier }\end{array}$ & $\begin{array}{l}\text { Maximum } \\
\text { Value }\end{array}$ & $\begin{array}{l}\text { Mean } \\
\text { Value }\end{array}$ & $\begin{array}{l}\text { Standard } \\
\text { Deviation }\end{array}$ & Units \\
\hline RAD & $\begin{array}{l}A M-241 \\
C M-243,244 \\
C M-245,246 \\
C M-248 \\
C O-60 \\
C S-137 \\
E U-152 \\
E U-154 \\
P U-238 \\
P U-239,240 \\
S R-90 \\
U-234 \\
U-235 \\
U-238\end{array}$ & $\begin{array}{r}24 \\
24 \\
7 \\
16 \\
519 \\
525 \\
266 \\
75 \\
24 \\
24 \\
24 \\
24 \\
107 \\
24\end{array}$ & $\begin{array}{l}J \\
J \\
V / V \\
J \\
U J \\
V / V \\
U \\
U \\
V / V \\
V / V \\
J \\
J \\
\text { NOTV } \\
J\end{array}$ & $\begin{array}{r}0.00 \\
0.00 \\
0.26 \\
0.26 \\
0.00 \\
1.47 \\
8.10 \\
2.51 \\
0.37 \\
31.08 \\
836.94 \\
60.68 \\
0.74 \\
58.46\end{array}$ & $\begin{array}{l}J \\
V / V \\
V / V \\
V / V \\
J \\
V / V \\
u \\
u \\
V / V \\
J \\
J \\
V / V \\
u \\
V / V\end{array}$ & $\begin{array}{r}1272.80 \\
1.05 \\
4.99 \\
1.84 \\
7074.91 \\
2186065.09 \\
1694.60 \\
520.56 \\
655.27 \\
11927.32 \\
42094.90 \\
444.74 \\
1517.57 \\
253.82\end{array}$ & $\begin{array}{r}288.29 \\
0.21 \\
2.06 \\
0.69 \\
757.25 \\
119992.53 \\
104.99 \\
72.66 \\
68.91 \\
3059.81 \\
16459.94 \\
210.76 \\
162.40 \\
146.67\end{array}$ & $\begin{array}{r}376.73 \\
0.28 \\
2.04 \\
0.53 \\
1571.67 \\
261983.21 \\
237.56 \\
103.03 \\
137.87 \\
3700.81 \\
15727.34 \\
130.51 \\
268.55 \\
70.64\end{array}$ & $\begin{array}{l}B Q / K G \\
B Q / K G \\
B Q / K G \\
B Q / K G \\
B Q / K G \\
B Q / K G \\
B Q / K G \\
B Q / K G \\
B Q / K G \\
B Q / K G \\
B Q / K G \\
B Q / K G \\
B Q / K G \\
B Q / K G\end{array}$ \\
\hline
\end{tabular}

\section{-QuAlifier CODEs:}

$U=$ Compound was analyzed for but not detected.

$J=$ Indicates an est imated value.

$U J=$ Compound was analyzed for but not detected and quantitation limit is an estimated value.

NJ = Tentative compound identification only and estimated concentration. Ho second colum confirmation of pesticides.

$V / V=$ Indicates that the result has been reviewed and is a valid result.

NOTV = Result has not been validated. Value corroborated by historical data and/or validated results for colocated samples and should be considered a reliable estimate. 
83

Table D4. Summary of individual core radionuclide concentrations in WOCE

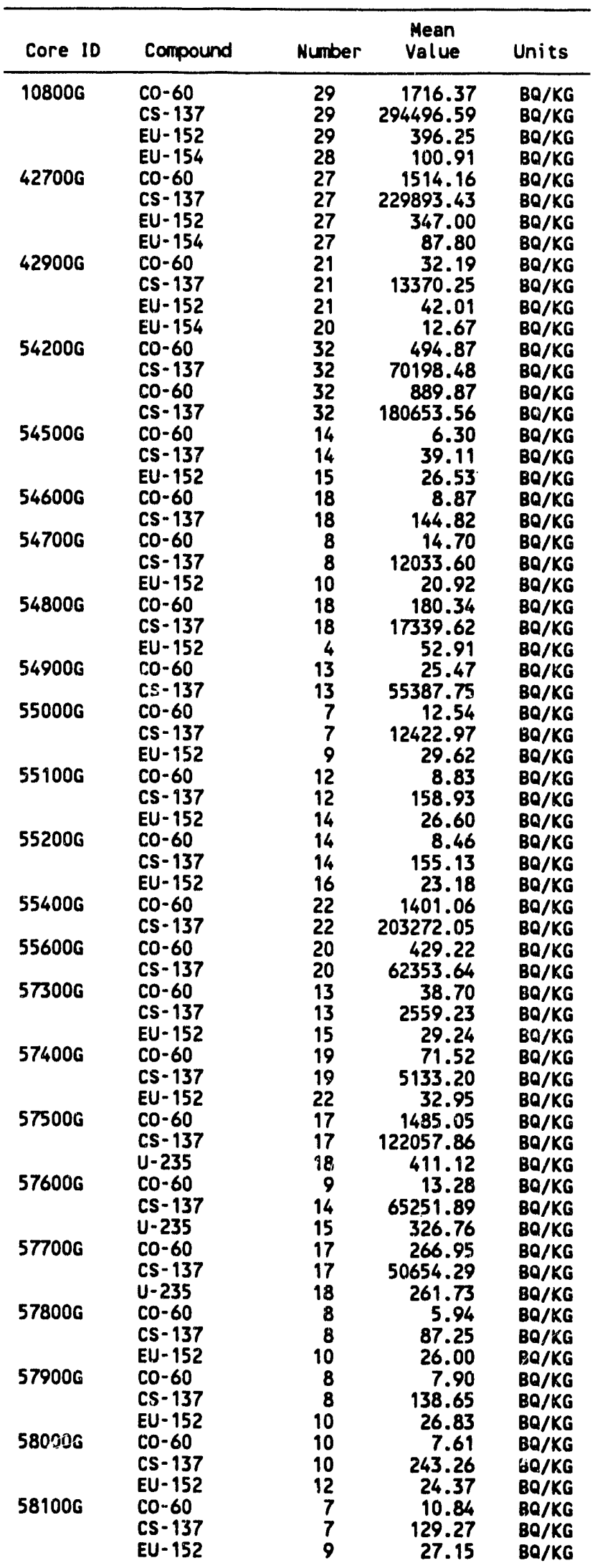


84

Table D4 (continued)

\begin{tabular}{|c|c|c|c|c|}
\hline Core ID & Compound & Number & $\begin{array}{l}\text { Mean } \\
\text { Value }\end{array}$ & Units \\
\hline $\begin{array}{l}58300 G \\
58400 G \\
58500 G \\
58600 G \\
63400 G \\
9500 G \\
9500 R\end{array}$ & 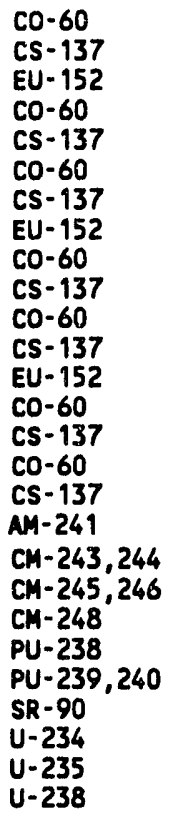 & $\begin{array}{r}21 \\
21 \\
23 \\
18 \\
18 \\
22 \\
22 \\
3 \\
21 \\
21 \\
13 \\
13 \\
17 \\
6 \\
6 \\
23 \\
24 \\
24 \\
24 \\
7 \\
16 \\
24 \\
24 \\
24 \\
24 \\
56 \\
24\end{array}$ & $\begin{array}{r}825.95 \\
103606.83 \\
64.60 \\
1682.50 \\
188266.97 \\
2116.07 \\
369981.54 \\
33.87 \\
1096.18 \\
300250.93 \\
94.56 \\
4021.03 \\
31.84 \\
1180.19 \\
85948.81 \\
2441.99 \\
351494.98 \\
288.29 \\
0.21 \\
2.06 \\
0.69 \\
68.91 \\
3059.81 \\
16459.94 \\
210.76 \\
6.49 \\
146.67\end{array}$ & $\begin{array}{l}B Q / K G \\
B Q / K G \\
B Q / K G \\
B Q / K G \\
B Q / K G \\
B Q / K G \\
B Q / K G \\
B Q / K G \\
B Q / K G \\
B Q / K G \\
B Q / K G \\
B Q / K G \\
B Q / K G \\
B Q / K G \\
B Q / K G \\
B Q / K G \\
B Q / K G \\
B Q / K G \\
B Q / K G \\
B Q / K G \\
B Q / K G \\
B Q / K G \\
B Q / K G \\
B Q / K G \\
B Q / K G \\
B Q / K G \\
B Q / K G\end{array}$ \\
\hline
\end{tabular}

"Core 9500 was a resubmittal of 95000 


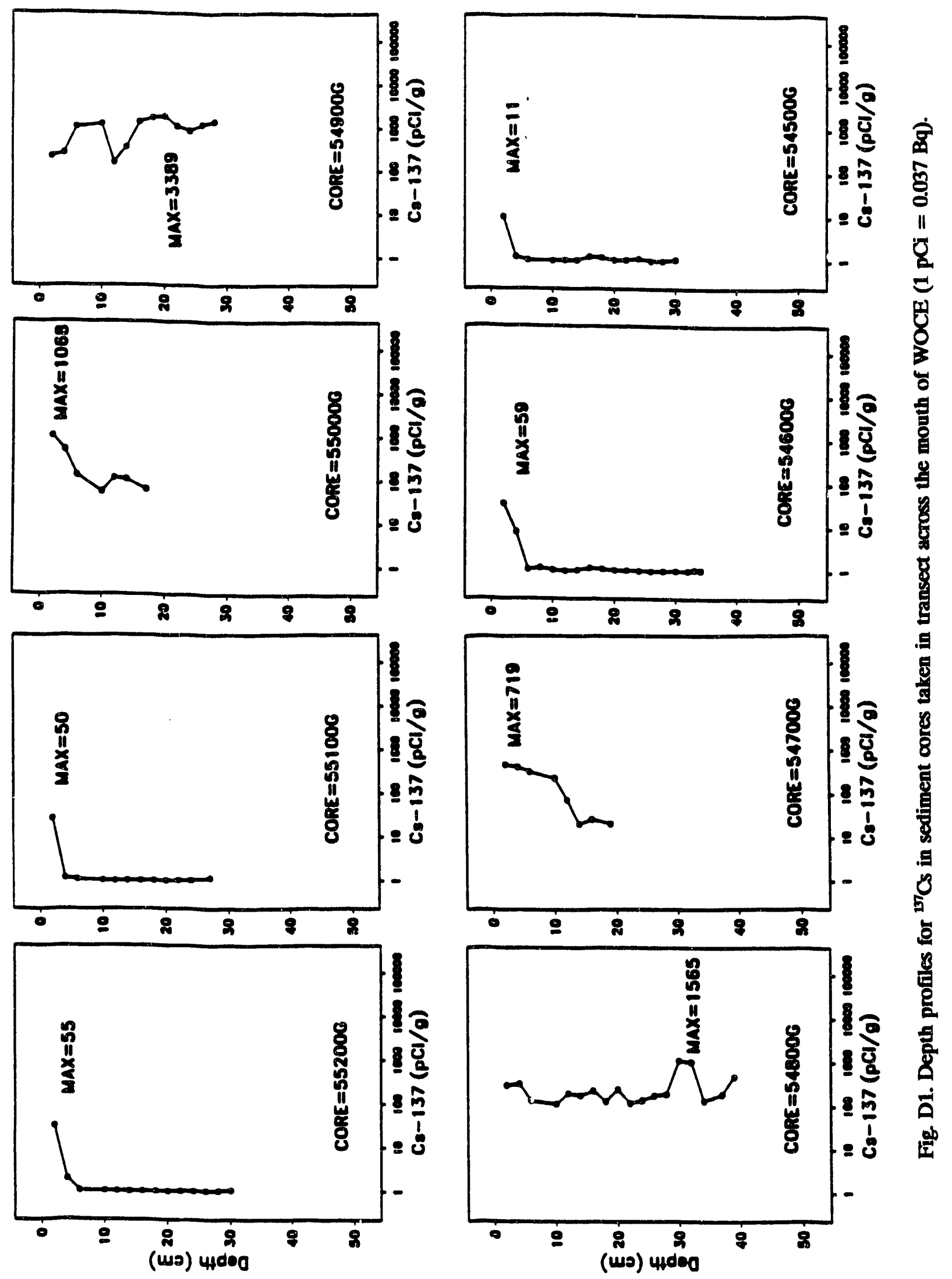



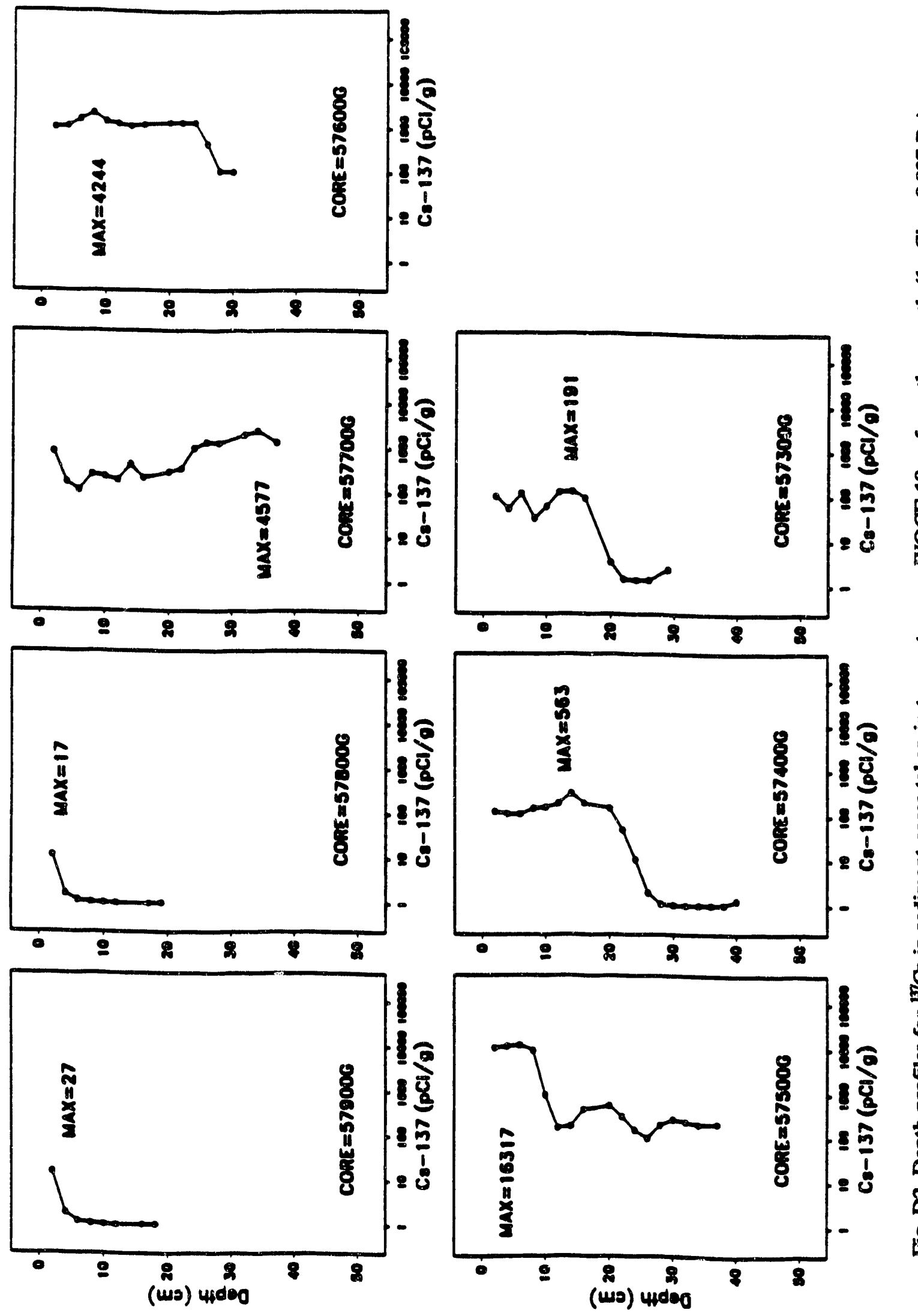

8 


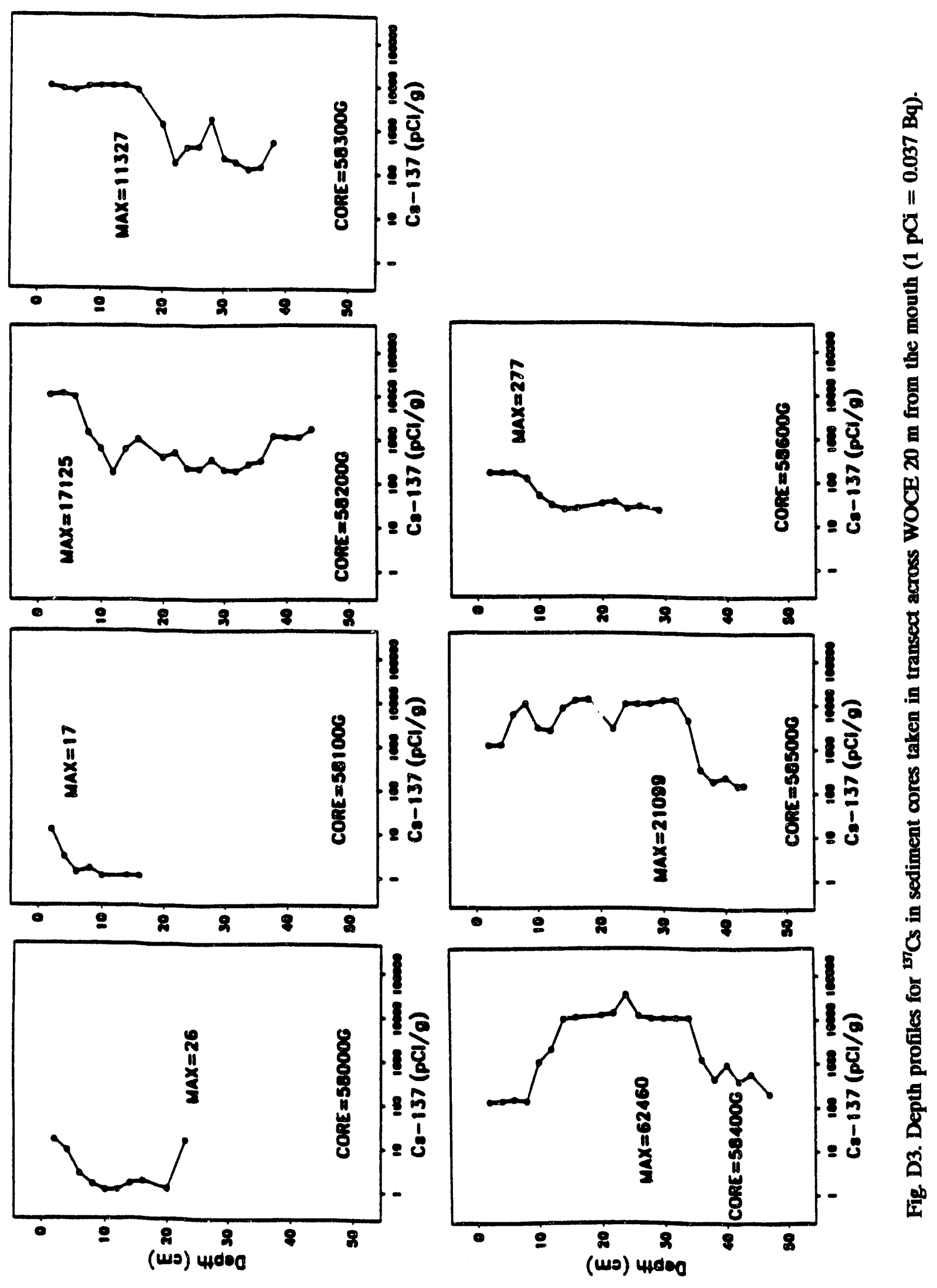



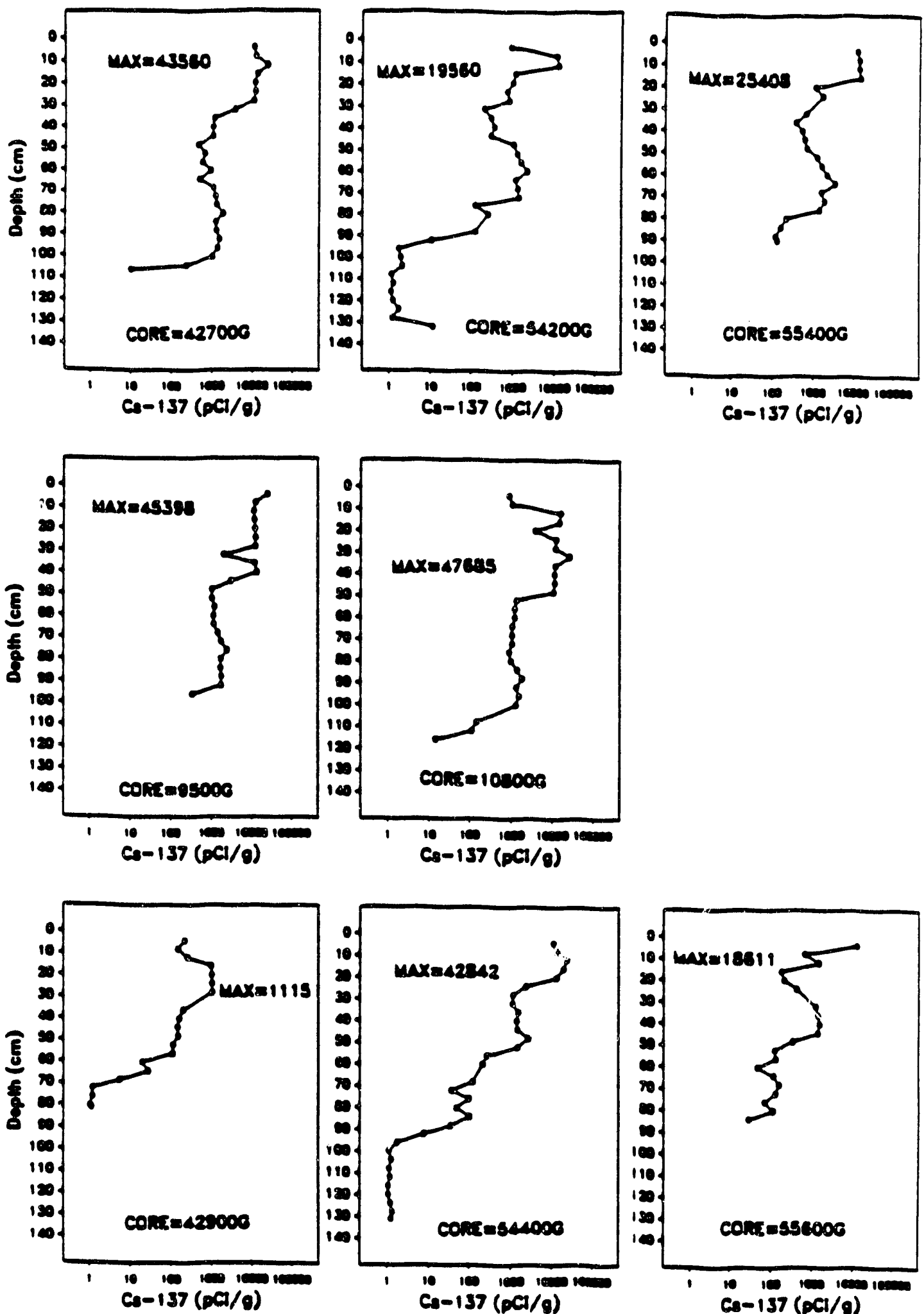

Fig. D4. Depth profiles for ${ }^{137} \mathrm{Cs}$ in sediment cores taken adjacent to each other at three locations in the embayment (Fig. 1.6). 
Appendix E

SUMMARY OF NATIONAL POLLUTANT DISCHARGE ELIMINATION SYSTEM (NPDES) DATA COILECTED AT WHITE OAK CREEK DAM FROM JANUARY 1989 TO SEPTEMBER 1990 
Table E1. Summary of White Oak Creek Dam NPDES and radiological data collected from January 1989 - September 1990

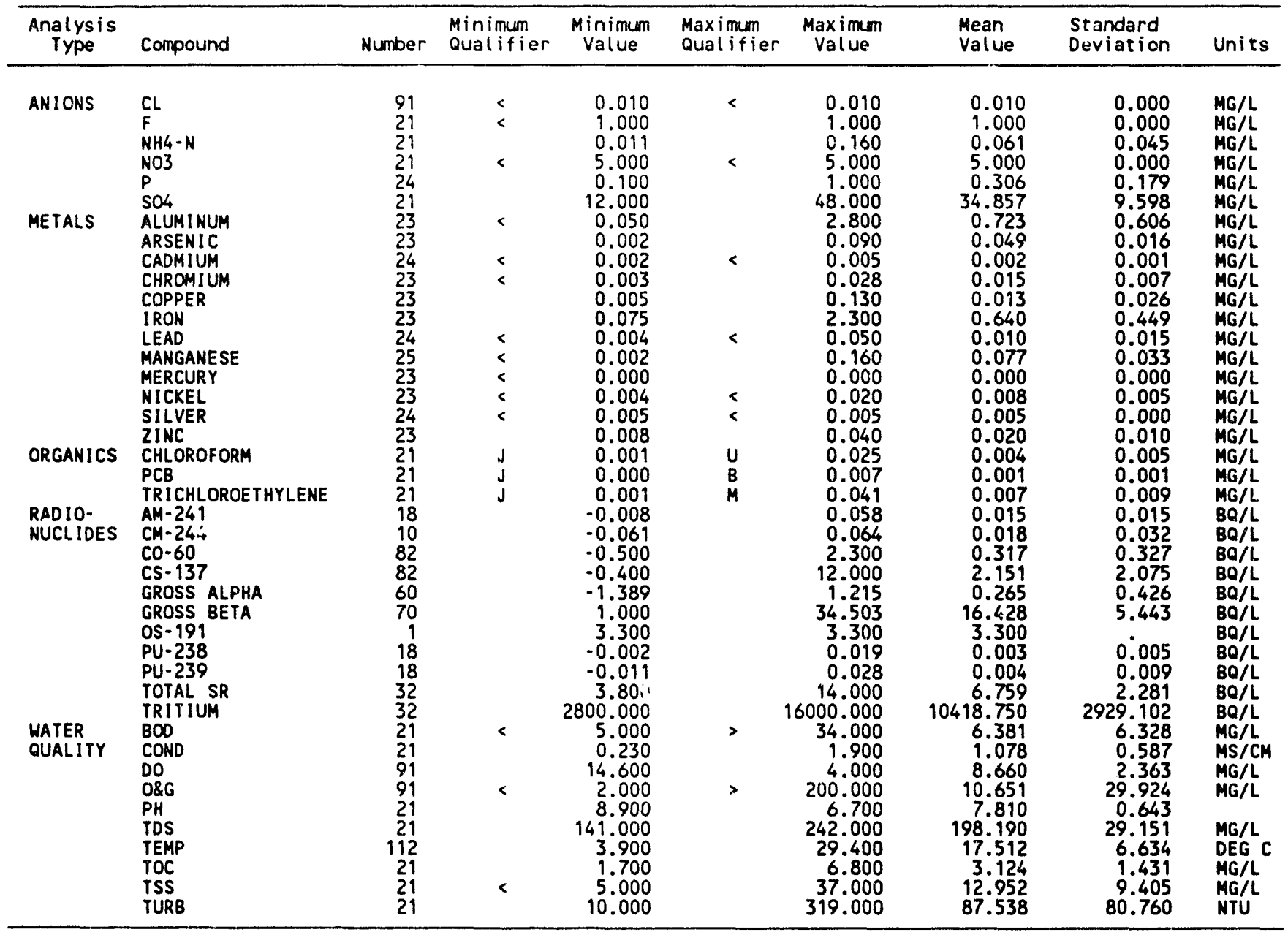

$<=$ less than detection limit.

$J=$ value is estimated .. compound identified but value less than cotract required quantitation limit.

$B=$ compound also detected in blank sample. 
Appendix F

SUMMARY OF CONTAMINANT CONCENTRATIONS IN WHITE OAK CREEK EMBAYMENT WATER SAMPLES COLLECTED IN 1990 
Table F1. Summery of inorganic, organic, and radioactive contaminant concentrations in woce water samples collected in 1990 .

\begin{tabular}{|c|c|c|c|c|c|c|c|c|}
\hline $\begin{array}{c}\text { Analys is } \\
\text { Type }\end{array}$ & Compound & Number & $\operatorname{Min}_{\text {Qual• }}$ & $\underset{\text { Value }}{\text { Minimum }}$ & $\begin{array}{l}\text { Max } \\
\text { Qual }\end{array}$ & $\begin{array}{l}\text { Maximum } \\
\text { Value }\end{array}$ & $\begin{array}{l}\text { Mean } \\
\text { Value }\end{array}$ & Units \\
\hline ETALS & 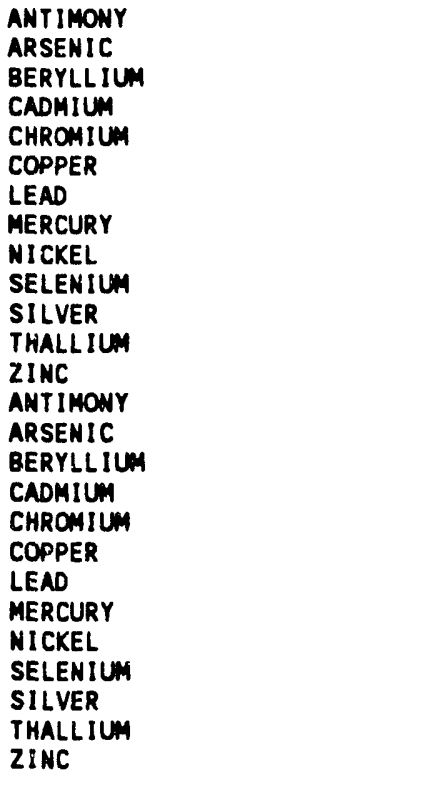 & $\begin{array}{l}1 \\
1 \\
1 \\
1 \\
1 \\
1 \\
1 \\
1 \\
1 \\
1 \\
1 \\
1 \\
1 \\
1 \\
1 \\
1 \\
1 \\
1 \\
1 \\
1 \\
1 \\
1 \\
1 \\
1 \\
1 \\
1\end{array}$ & $\begin{array}{l}U \\
U \\
U \\
V / V \\
U \\
U \\
U \\
U \\
U \\
U \\
U \\
U \\
V / V \\
U \\
U \\
U \\
V / V \\
V / V \\
U \\
U \\
U \\
U \\
U \\
U \\
U \\
V / V\end{array}$ & $\begin{array}{l}0.00190 \\
0.00130 \\
0.00390 \\
0.00240 \\
0.00980 \\
0.00440 \\
0.00100 \\
0.00020 \\
0.01900 \\
0.00097 \\
0.00074 \\
0.00270 \\
0.02000 \\
0.00190 \\
0.00130 \\
0.00390 \\
0.00036 \\
0.01000 \\
0.00440 \\
0.00180 \\
0.00020 \\
0.01900 \\
0.00097 \\
0.00074 \\
0.00270 \\
0.01900\end{array}$ & $\begin{array}{l}U \\
U \\
U \\
V / V \\
U \\
U \\
U \\
U \\
U \\
U \\
U \\
U \\
V / V \\
U \\
U \\
U \\
V / V \\
V / V \\
U \\
U \\
U \\
U \\
U \\
U \\
U \\
V / V\end{array}$ & $\begin{array}{l}0.00190 \\
0.00130 \\
0.00390 \\
0.00240 \\
0.00980 \\
0.00440 \\
0.00100 \\
0.00020 \\
0.01900 \\
0.00097 \\
0.00074 \\
0.00270 \\
0.02000 \\
0.00190 \\
0.00130 \\
0.00390 \\
0.00036 \\
0.01000 \\
0.00440 \\
0.00180 \\
0.00020 \\
0.01900 \\
0.00097 \\
0.00074 \\
0.00270 \\
0.01900\end{array}$ & $\begin{array}{l}0.00190 \\
0.00130 \\
0.00390 \\
0.00240 \\
0.00980 \\
0.00440 \\
0.00100 \\
0.00020 \\
0.01900 \\
0.00097 \\
0.00074 \\
0.00270 \\
0.02000 \\
0.00190 \\
0.00130 \\
0.00390 \\
0.00036 \\
0.01000 \\
0.00440 \\
0.00180 \\
0.00020 \\
0.01900 \\
0.00097 \\
0.00074 \\
0.00270 \\
0.01900\end{array}$ & $\begin{array}{l}M G / L \\
M G / L \\
M G / L \\
M G / L \\
M G / L \\
M G / L \\
M G / L \\
M G / L \\
M G / L \\
M G / L \\
M G / L \\
M G / L \\
M G / L \\
M G / L \\
M G / L \\
M G / L \\
M G / L \\
M G / L \\
M G / L \\
M G / L \\
M G / L \\
M G / L \\
M G / L \\
M G / L \\
M G / L \\
M G / L\end{array}$ \\
\hline ORGANICS & 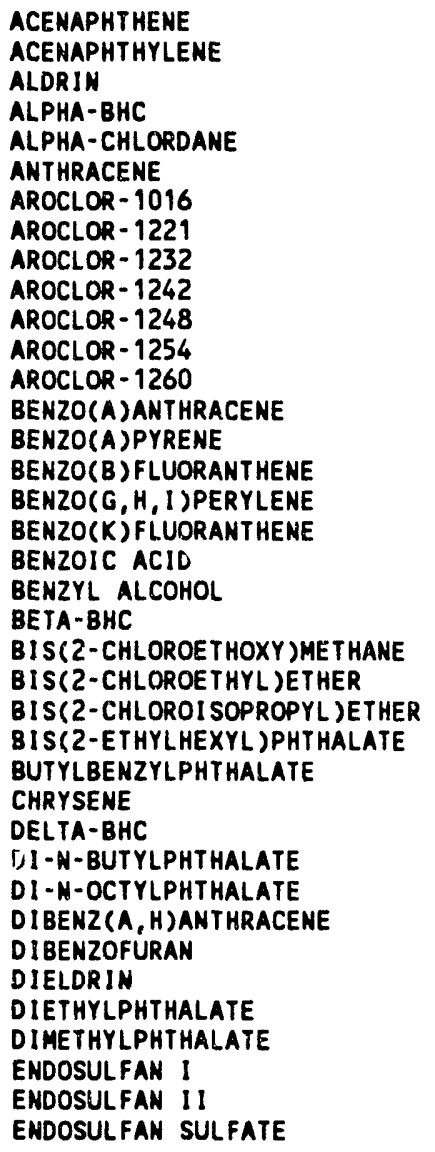 & $\begin{array}{l}1 \\
1 \\
1 \\
1 \\
1 \\
1 \\
1 \\
1 \\
1 \\
1 \\
1 \\
1 \\
1 \\
1 \\
1 \\
1 \\
1 \\
1 \\
1 \\
1 \\
1 \\
1 \\
1 \\
1 \\
1 \\
1 \\
1 \\
1 \\
1 \\
1 \\
1 \\
1 \\
1 \\
1 \\
1 \\
1 \\
1 \\
1\end{array}$ & $\begin{array}{l}U \\
U \\
U \\
U \\
U \\
U U \\
U \\
U \\
U \\
U \\
U \\
U \\
U \\
U \\
U \\
U \\
U \\
U \\
U \\
U \\
U \\
U \\
U \\
U \\
U \\
U \\
U \\
U \\
U \\
U \\
U U \\
U \\
U \\
U \\
U \\
U \\
U \\
U \\
U \\
U\end{array}$ & $\begin{array}{l}0.01000 \\
0.01000 \\
0.00005 \\
0.00005 \\
0.00050 \\
0.01000 \\
0.00050 \\
0.00050 \\
0.00050 \\
0.00050 \\
0.00050 \\
0.00100 \\
0.00100 \\
0.01000 \\
0.01000 \\
0.01000 \\
0.01000 \\
0.01000 \\
0.05000 \\
1.01000 \\
0.00005 \\
0.01000 \\
0.01000 \\
0.01000 \\
0.01000 \\
0.01000 \\
0.01000 \\
0.00005 \\
0.01000 \\
0.01000 \\
0.01000 \\
0.01000 \\
0.00010 \\
0.01000 \\
0.01000 \\
0.00005 \\
0.00010 \\
0.00010\end{array}$ & $\begin{array}{l}U \\
U U \\
U \\
U \\
U \\
U \\
U \\
U \\
U \\
U \\
U \\
U \\
U \\
U \\
U \\
U \\
U \\
U \\
U \\
U \\
U \\
U \\
U \\
U \\
U \\
U \\
U \\
U \\
U \\
U \\
U \\
U \\
U \\
U \\
U \\
U \\
U \\
U \\
U \\
U\end{array}$ & $\begin{array}{l}0.01000 \\
0.01000 \\
0.00005 \\
0.00005 \\
0.00050 \\
0.01000 \\
0.00050 \\
0.00050 \\
0.00050 \\
0.00050 \\
0.00050 \\
0.00100 \\
0.00100 \\
0.01000 \\
0.01000 \\
0.01000 \\
0.01000 \\
0.01000 \\
0.05000 \\
0.01000 \\
0.00005 \\
0.01000 \\
0.01000 \\
0.01000 \\
0.01000 \\
0.01000 \\
0.01000 \\
0.00005 \\
0.01000 \\
0.01000 \\
0.01000 \\
0.01000 \\
0.00010 \\
0.01000 \\
0.01000 \\
0.00005 \\
0.00010 \\
0.00010\end{array}$ & $\begin{array}{l}0.01000 \\
0.01000 \\
0.00005 \\
0.00005 \\
0.00050 \\
0.01000 \\
0.00050 \\
0.00050 \\
0.00050 \\
0.00050 \\
0.00050 \\
0.00100 \\
0.00100 \\
0.01000 \\
0.01000 \\
0.01000 \\
0.01000 \\
0.01000 \\
0.05000 \\
0.01000 \\
0.00005 \\
0.01000 \\
0.01000 \\
0.01000 \\
0.01000 \\
0.01000 \\
0.01000 \\
0.00005 \\
0.01000 \\
0.01000 \\
0.01000 \\
0.01000 \\
0.00010 \\
0.01000 \\
0.01000 \\
0.00005 \\
0.00010 \\
0.00010\end{array}$ & $\begin{array}{l}M G / L \\
M G / L \\
M G / L \\
M G / L \\
M G / L \\
M G / L \\
M G / L \\
M G / L \\
M G / L \\
M G / L \\
M G / L \\
M G / L \\
M G / L \\
M G / L \\
M G / L \\
M G / L \\
M G / L \\
M G / L \\
M G / L \\
M G / L \\
M G / L \\
M G / L \\
M G / L \\
M G / L \\
M G / L \\
M G / L \\
M G / L \\
M G / L \\
M G / L \\
M G / L \\
M G / L \\
M G / L \\
M G / L \\
M G / L \\
M G / L \\
M G / L \\
M G / L \\
M G / L\end{array}$ \\
\hline
\end{tabular}


Table F1 (continued)

\begin{tabular}{|c|c|c|c|c|c|c|c|c|}
\hline $\begin{array}{c}\text { Analys is } \\
\text { Type }\end{array}$ & Compound & Number & $\begin{array}{l}\text { Min } \\
\text { Qual. }\end{array}$ & $\begin{array}{l}\text { Minimum } \\
\text { Value }\end{array}$ & $\begin{array}{l}\text { Max } \\
\text { Qual }\end{array}$ & $\begin{array}{l}\text { Maximum } \\
\text { Value }\end{array}$ & $\begin{array}{l}\text { Mean } \\
\text { Velue }\end{array}$ & Units \\
\hline ORGANICS & 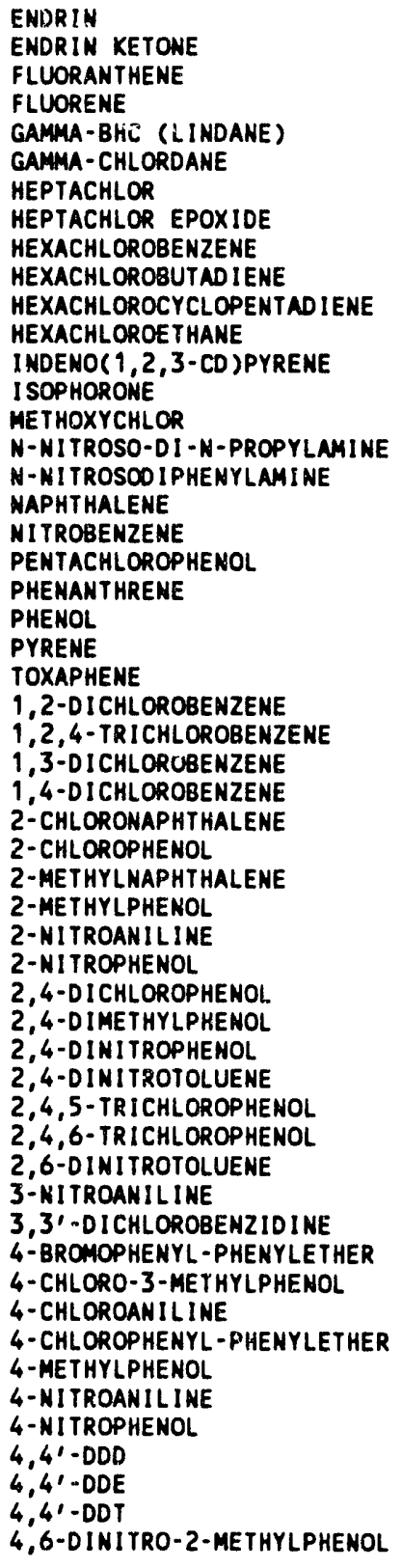 & $\begin{array}{l}1 \\
1 \\
1 \\
1 \\
1 \\
1 \\
1 \\
1 \\
1 \\
1 \\
1 \\
1 \\
1 \\
1 \\
1 \\
1 \\
1 \\
1 \\
1 \\
1 \\
1 \\
1 \\
1 \\
1 \\
1 \\
1 \\
1 \\
1 \\
1 \\
1 \\
1 \\
1 \\
1 \\
1 \\
1 \\
1 \\
1 \\
1 \\
1 \\
1 \\
1 \\
1 \\
1 \\
1 \\
1 \\
1 \\
1 \\
1 \\
1 \\
1 \\
1 \\
1 \\
1 \\
1\end{array}$ & $\begin{array}{l}U \\
U \\
U \\
U \\
U \\
U \\
U \\
U \\
U \\
U \\
U \\
U \\
U \\
U \\
U \\
U \\
U \\
U \\
U \\
U \\
U \\
U \\
U \\
U \\
U \\
U \\
U \\
U \\
U \\
U \\
U \\
U \\
U \\
U \\
U \\
U \\
U \\
U \\
U \\
U \\
U \\
U \\
U \\
U \\
U \\
U \\
U \\
U \\
U \\
U \\
U \\
U \\
U\end{array}$ & $\begin{array}{l}0.00010 \\
0.00010 \\
0.01000 \\
0.01000 \\
0.00005 \\
0.00050 \\
0.00005 \\
0.00005 \\
0.01000 \\
0.01000 \\
0.01000 \\
0.01000 \\
0.01000 \\
0.01000 \\
0.00050 \\
0.01000 \\
0.01000 \\
0.01000 \\
0.01000 \\
0.05000 \\
0.01000 \\
0.01000 \\
0.01000 \\
0.00100 \\
0.01000 \\
0.01000 \\
0.01000 \\
0.01000 \\
0.01000 \\
0.01000 \\
0.01000 \\
0.01000 \\
0.05000 \\
0.01000 \\
0.01000 \\
0.01000 \\
0.05000 \\
0.01000 \\
0.05000 \\
0.01000 \\
0.01000 \\
0.05000 \\
0.02000 \\
0.01000 \\
0.01000 \\
0.11000 \\
0.01000 \\
0.11000 \\
0.45000 \\
0.05000 \\
0.00010 \\
0.00010 \\
0.00010 \\
0.05000\end{array}$ & $\begin{array}{l}U \\
U \\
U \\
U \\
U \\
U \\
U \\
U \\
U \\
U \\
U \\
U \\
U \\
U \\
U \\
U \\
U \\
U \\
U \\
U \\
U \\
U \\
U \\
U \\
U \\
U \\
U \\
U \\
U \\
U \\
U \\
U \\
U \\
U \\
U \\
U \\
U \\
U \\
U \\
U \\
U \\
U \\
U \\
U \\
U \\
U \\
U \\
U \\
U \\
U \\
U \\
U \\
U \\
U \\
U\end{array}$ & $\begin{array}{l}0.00010 \\
0.00010 \\
0.01000 \\
0.01000 \\
0.00005 \\
0.00050 \\
0.00005 \\
0.00005 \\
0.01000 \\
0.01000 \\
0.01000 \\
0.01000 \\
0.01000 \\
0.01000 \\
0.00050 \\
0.01000 \\
0.01000 \\
0.01000 \\
0.01000 \\
0.05000 \\
0.01000 \\
0.01000 \\
0.01000 \\
0.00100 \\
0.01000 \\
0.01000 \\
0.01000 \\
0.01000 \\
0.01000 \\
0.01000 \\
0.01000 \\
0.01000 \\
0.05000 \\
0.01000 \\
0.01000 \\
0.01000 \\
0.05000 \\
0.01000 \\
0.05000 \\
0.01000 \\
0.01000 \\
0.05000 \\
0.02000 \\
0.01000 \\
0.01000 \\
0.01000 \\
0.01000 \\
0.01000 \\
0.05000 \\
0.05000 \\
0.00010 \\
0.00010 \\
0.00010 \\
0.05000\end{array}$ & $\begin{array}{l}0.00010 \\
0.00010 \\
0.01000 \\
0.01000 \\
0.00005 \\
0.00050 \\
0.00005 \\
0.00005 \\
0.01000 \\
0.01000 \\
0.01000 \\
0.01000 \\
0.01000 \\
0.01000 \\
0.00050 \\
0.01000 \\
0.01000 \\
0.01000 \\
0.01000 \\
0.05000 \\
0.01000 \\
0.01000 \\
0.01000 \\
0.00100 \\
0.01000 \\
0.01000 \\
0.01000 \\
0.01000 \\
0.01000 \\
0.01000 \\
0.01000 \\
0.01000 \\
0.05000 \\
0.01000 \\
0.01000 \\
0.01000 \\
0.05000 \\
0.01000 \\
0.05000 \\
0.01000 \\
0.01000 \\
0.05000 \\
0.02000 \\
0.01000 \\
0.01000 \\
0.01000 \\
0.01000 \\
0.01000 \\
0.05000 \\
0.05000 \\
0.00010 \\
0.00010 \\
0.00010 \\
0.05000\end{array}$ & $\begin{array}{l}M G / L \\
M G / L \\
M G / L \\
M G / L \\
M G / L \\
M G / L \\
M G / L \\
M G / L \\
M G / L \\
M G / L \\
M G / L \\
M G / L \\
M G / L \\
M G / L \\
M G / L \\
M G / L \\
M G / L \\
M G / L \\
M G / L \\
M G / L \\
M G / L \\
M G / L \\
M G / L \\
M G / L \\
M G / L \\
M G / L \\
M G / L \\
M G / L \\
M G / L \\
M G / L \\
M G / L \\
M G / L \\
M G / L \\
M G / L \\
M G / L \\
M G / L \\
M G / L \\
M G / L \\
M G / L \\
M G / L \\
M G / L \\
M G / L \\
M G / L \\
M G / L \\
M G / L \\
M G / L \\
M G / L \\
M G / L \\
M G / L \\
M G / L \\
M G / L \\
M G / L \\
M G / L \\
M G / L\end{array}$ \\
\hline RAD & $\begin{array}{l}H-3 \\
S R-90\end{array}$ & $\begin{array}{l}2 \\
3\end{array}$ & $\begin{array}{l}\text { NOTV } \\
\text { NOTV }\end{array}$ & $\begin{array}{r}10926.10 \\
7.27420\end{array}$ & NOTV & $\begin{array}{r}11037.10 \\
8.09560\end{array}$ & $\begin{array}{r}10981.60 \\
7.82180\end{array}$ & $\begin{array}{l}80 / L \\
B O / L\end{array}$ \\
\hline
\end{tabular}

"QuALIFIER COOES:

$U=$ Compound was analyzed for but not detected.

$J=$ Indicates an estimated value.

$\mathrm{UJ}=$ Compound was analyzed for but not detected and quantitation limit is on estimated value.

$\mathrm{NJ}=$ Tentative compound identification only and estimated concentration. No second column confirmation of pesticides.

$V / V=$ Indicates that the result has been reviewed and is a valid result .

NOTV = Result not valid and for limited use in this report only. Value corroborated by ORNL radiological monitoring data but should be considered approximate. 
Appendix G

SUMMARY OF CONTAMINANT CONCENTRATIONS

IN WHITE OAK CREEK EMBAYMENT FISH

COLLECTED IN 1990 
Table G1. Summary of contaminant concentrations in WOCE fish samples collected in 1990

\begin{tabular}{|c|c|c|c|c|c|c|c|c|c|}
\hline $\begin{array}{c}\text { Analys is } \\
\text { Type }\end{array}$ & Compound & Number & $\begin{array}{l}\text { Min } \\
\text { Qual. }\end{array}$ & $\begin{array}{l}\text { Minimum } \\
\text { Value }\end{array}$ & $\begin{array}{l}\text { Max } \\
\text { Qual }\end{array}$ & $\begin{array}{l}\text { Maximum } \\
\text { Value }\end{array}$ & $\begin{array}{l}\text { Mean } \\
\text { Value }\end{array}$ & $\begin{array}{l}\text { Standard } \\
\text { Deviation }\end{array}$ & Units \\
\hline METALS & $\begin{array}{l}\text { ANT IMONY } \\
\text { ARSENIC } \\
\text { BERYLLIUM } \\
\text { CADMIUM } \\
\text { CHROMIUW } \\
\text { COPPER } \\
\text { LEAD } \\
\text { MERCURY } \\
\text { NICKEL } \\
\text { SELENIUM } \\
\text { SILVER } \\
\text { THALLIUM } \\
\text { ZINC }\end{array}$ & $\begin{array}{r}14 \\
14 \\
8 \\
14 \\
14 \\
14 \\
14 \\
16 \\
14 \\
14 \\
14 \\
14 \\
14\end{array}$ & $\begin{array}{l}\text { UJ } \\
\text { UJ } \\
\text { UJ } \\
\text { UJ } \\
\text { UJ } \\
\text { UJ } \\
\text { UJ } \\
J \\
\text { UJ } \\
\text { UJ } \\
\text { UJ } \\
\text { UJ } \\
J\end{array}$ & $\begin{array}{l}0.330 \\
0.050 \\
0.003 \\
0.130 \\
0.330 \\
0.330 \\
0.330 \\
0.055 \\
0.330 \\
0.380 \\
0.130 \\
0.020 \\
4.600\end{array}$ & $\begin{array}{l}\text { UJ } \\
J \\
\text { UJ } \\
\text { UJ } \\
\text { UJ } \\
J \\
\text { UJ } \\
J \\
\text { UJ } \\
J \\
\text { UJ } \\
\text { UJ } \\
J\end{array}$ & $\begin{array}{r}0.490 \\
0.250 \\
0.003 \\
0.200 \\
0.490 \\
1.000 \\
0.490 \\
0.256 \\
0.490 \\
1.100 \\
0.200 \\
0.020 \\
12.000\end{array}$ & $\begin{array}{l}0.404 \\
0.097 \\
0.003 \\
0.160 \\
0.404 \\
0.484 \\
0.404 \\
0.146 \\
0.404 \\
0.631 \\
0.160 \\
0.020 \\
6.921\end{array}$ & $\begin{array}{l}0.062 \\
0.067 \\
0.000 \\
0.026 \\
0.062 \\
0.192 \\
0.062 \\
0.062 \\
0.062 \\
0.204 \\
0.026 \\
0.000 \\
1.926\end{array}$ & $\begin{array}{l}M G / K G \\
M G / K G \\
M G / K G \\
M G / K G \\
M G / K G \\
M G / K G \\
M G / K G \\
M G / K G \\
M G / K G \\
M G / K G \\
M G / K G \\
M G / K G \\
M G / K G\end{array}$ \\
\hline ORGANICS & 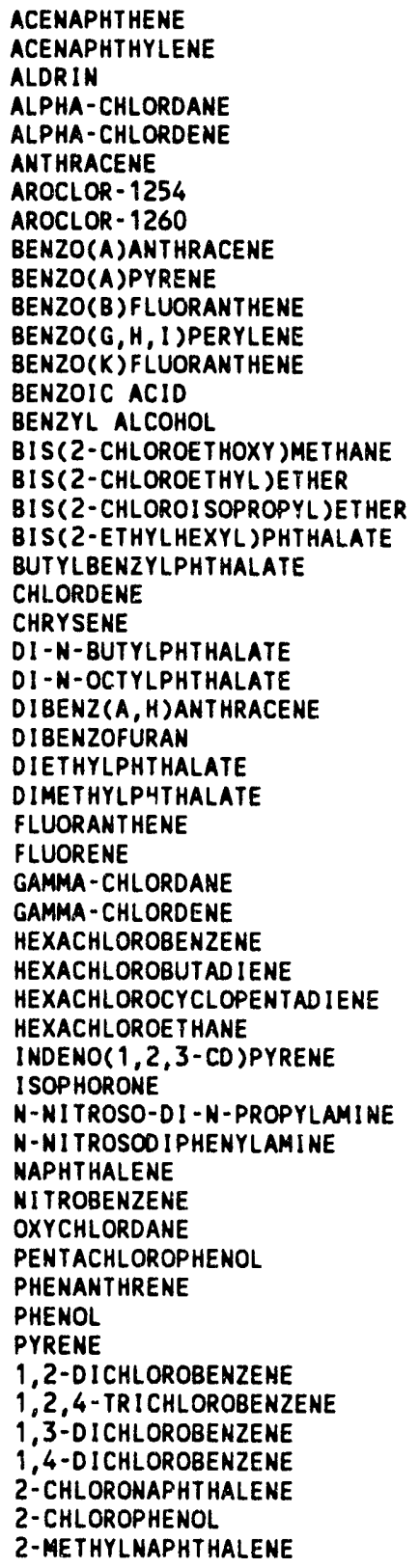 & $\begin{array}{l}8 \\
8 \\
8 \\
8 \\
8 \\
8 \\
8 \\
8 \\
8 \\
8 \\
8 \\
8 \\
8 \\
8 \\
8 \\
8 \\
8 \\
8 \\
8 \\
8 \\
8 \\
8 \\
8 \\
8 \\
8 \\
8 \\
8 \\
8 \\
8 \\
8 \\
8 \\
8 \\
8 \\
8 \\
8 \\
8 \\
8 \\
8 \\
8 \\
8 \\
8 \\
8 \\
8 \\
8 \\
8 \\
8 \\
8 \\
8 \\
8 \\
8 \\
8 \\
8\end{array}$ & $\begin{array}{l}U X \\
U X \\
U X \\
J \\
J \\
U J \\
U J \\
U J \\
U X \\
U X \\
U X \\
U X \\
U X \\
U X \\
U X \\
U X \\
U X \\
U X \\
U X \\
U X \\
U X \\
U X \\
J \\
U X \\
U J \\
U X \\
U X \\
U X \\
U X \\
U X \\
U X \\
U J \\
U X \\
J \\
J \\
U J \\
U X \\
U X \\
U X \\
U X \\
U X \\
U X \\
U X \\
U J \\
U X \\
U X \\
J \\
U J \\
U J \\
U X \\
U X \\
U X \\
U X \\
U X \\
U X \\
U X \\
U X \\
U X \\
U X \\
\end{array}$ & $\begin{array}{l}0.540 \\
0.540 \\
0.100 \\
0.016 \\
0.001 \\
0.540 \\
0.040 \\
0.380 \\
0.540 \\
0.540 \\
0.540 \\
0.540 \\
0.540 \\
2.700 \\
0.540 \\
0.540 \\
0.540 \\
0.540 \\
0.540 \\
0.540 \\
0.001 \\
0.540 \\
0.540 \\
0.540 \\
0.540 \\
0.540 \\
0.540 \\
0.540 \\
0.540 \\
0.540 \\
0.008 \\
0.002 \\
0.540 \\
0.540 \\
0.540 \\
0.540 \\
0.540 \\
0.540 \\
0.540 \\
0.540 \\
0.540 \\
0.540 \\
0.003 \\
2.700 \\
0.540 \\
0.540 \\
0.540 \\
0.540 \\
0.540 \\
0.540 \\
0.540 \\
0.540 \\
0.540 \\
0.540\end{array}$ & $\begin{array}{l}U X \\
U X \\
U X \\
J \\
U X \\
U J \\
U J \\
U J J \\
N J \\
U X \\
U X \\
U X \\
U X \\
U X \\
U X \\
U X \\
U X \\
U X \\
U X \\
U X \\
U X \\
U X \\
U X \\
U X \\
U X \\
U J \\
U X \\
U X \\
U X \\
U X \\
U X \\
U X \\
U J \\
U X \\
J \\
U X \\
U J \\
U X \\
U X \\
U X \\
U X \\
U X \\
U X \\
U X \\
U J \\
U X \\
U X \\
U X \\
J \\
U J \\
U J \\
U X \\
U X \\
U X \\
U X \\
U X \\
U X \\
U X \\
U X \\
U X \\
U X\end{array}$ & $\begin{array}{l}0.790 \\
0.790 \\
0.100 \\
0.039 \\
0.100 \\
0.790 \\
1.210 \\
1.530 \\
0.790 \\
0.790 \\
0.790 \\
0.790 \\
0.790 \\
3.900 \\
0.790 \\
0.790 \\
0.790 \\
0.790 \\
0.790 \\
0.790 \\
0.100 \\
0.790 \\
0.790 \\
0.790 \\
0.790 \\
0.790 \\
0.790 \\
0.790 \\
0.790 \\
0.790 \\
0.027 \\
0.100 \\
0.790 \\
0.790 \\
0.790 \\
0.790 \\
0.790 \\
0.790 \\
0.790 \\
0.790 \\
0.790 \\
0.790 \\
0.012 \\
3.900 \\
0.790 \\
0.790 \\
0.790 \\
0.790 \\
0.790 \\
0.790 \\
0.790 \\
0.790 \\
0.790 \\
0.790\end{array}$ & $\begin{array}{l}0.667 \\
0.667 \\
0.100 \\
0.022 \\
0.064 \\
0.667 \\
0.554 \\
0.984 \\
0.667 \\
0.667 \\
0.667 \\
0.667 \\
0.667 \\
3.312 \\
0.667 \\
0.667 \\
0.667 \\
0.667 \\
0.667 \\
0.667 \\
0.075 \\
0.667 \\
0.667 \\
0.667 \\
0.667 \\
0.667 \\
0.667 \\
0.667 \\
0.667 \\
0.667 \\
0.013 \\
0.054 \\
0.667 \\
0.667 \\
0.667 \\
0.667 \\
0.667 \\
0.667 \\
0.667 \\
0.667 \\
0.667 \\
0.667 \\
0.005 \\
3.3112 \\
0.667 \\
0.667 \\
0.667 \\
0.667 \\
0.667 \\
0.667 \\
0.667 \\
0.6677 \\
0.6667 \\
0.667\end{array}$ & $\begin{array}{l}0.082 \\
0.082 \\
0.000 \\
0.007 \\
0.049 \\
0.082 \\
0.378 \\
0.507 \\
0.082 \\
0.082 \\
0.082 \\
0.082 \\
0.082 \\
0.398 \\
0.082 \\
0.082 \\
0.082 \\
0.082 \\
0.082 \\
0.082 \\
0.046 \\
0.082 \\
0.082 \\
0.082 \\
0.082 \\
0.082 \\
0.082 \\
0.082 \\
0.082 \\
0.082 \\
0.006 \\
0.049 \\
0.082 \\
0.082 \\
0.82 \\
0.082 \\
0.082 \\
0.082 \\
0.082 \\
0.082 \\
0.082 \\
0.082 \\
0.003 \\
0.398 \\
0.082 \\
0.082 \\
0.082 \\
0.082 \\
0.082 \\
0.082 \\
0.082 \\
0.082 \\
0.082 \\
0.082\end{array}$ & $\begin{array}{l}M G / K G \\
M G / K G \\
M G / K G \\
M G / K G \\
M G / K G \\
M G / K G \\
M G / K G \\
M G / K G \\
M G / K G \\
M G / K G \\
M G / K G \\
M G / K G \\
M G / K G \\
M G / K G \\
M G / K G \\
M G / K G \\
M G / K G \\
M G / K G \\
M G / K G \\
M G / K G \\
M G / K G \\
M G / K G \\
M G / K G \\
M G / K G \\
M G / K G \\
M G / K G \\
M G / K G \\
M G / K G \\
M G / K G \\
M G / K G \\
M G / K G \\
M G / K G \\
M G / K G \\
M G / K G \\
M G / K G \\
M G / K G \\
M G / K G \\
M G / K G \\
M G / K G \\
M G / K G \\
M G / K G \\
M G / K G \\
M G / K G \\
M G / K G \\
M G / K G \\
M G / K G \\
M G / K G \\
M G / K G \\
M G / K G \\
M G / K G \\
M G / K G \\
M G / K G \\
M G / K G \\
M G / K G\end{array}$ \\
\hline
\end{tabular}


Table G1 (continued)

\begin{tabular}{|c|c|c|c|c|c|c|c|c|c|}
\hline $\begin{array}{c}\text { Analys is } \\
\text { Type }\end{array}$ & Compound & Number & $\begin{array}{l}\text { Min } \\
\text { Qual }\end{array}$ & $\begin{array}{l}\text { Minimum } \\
\text { Value }\end{array}$ & $\begin{array}{l}\text { Max } \\
\text { Qual }\end{array}$ & $\begin{array}{l}\text { Maximum } \\
\text { Value }\end{array}$ & $\begin{array}{l}\text { Mean } \\
\text { Value }\end{array}$ & $\begin{array}{l}\text { Standard } \\
\text { Deviation }\end{array}$ & Units \\
\hline ORGANICS & 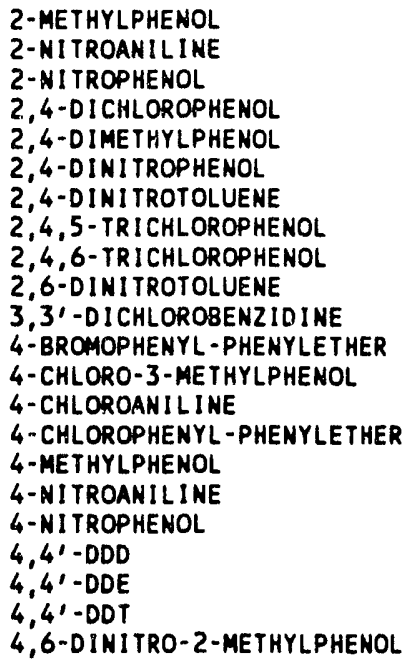 & $\begin{array}{l}8 \\
8 \\
8 \\
8 \\
8 \\
8 \\
8 \\
8 \\
8 \\
8 \\
8 \\
8 \\
8 \\
8 \\
8 \\
8 \\
8 \\
8 \\
8 \\
8 \\
8 \\
8\end{array}$ & $\begin{array}{l}U X \\
U X \\
U X \\
U X \\
U X \\
U X \\
U X \\
U X \\
U X \\
U X \\
U X \\
U J \\
U X \\
U J \\
U X \\
U X \\
U X \\
U X \\
J \\
U X \\
U X \\
U J\end{array}$ & $\begin{array}{l}0.540 \\
2.700 \\
0.540 \\
0.540 \\
0.540 \\
2.700 \\
0.540 \\
2.700 \\
0.540 \\
0.540 \\
1.100 \\
0.540 \\
0.540 \\
0.540 \\
0.540 \\
0.540 \\
2.700 \\
2.700 \\
0.008 \\
0.100 \\
0.100 \\
2.700\end{array}$ & $\begin{array}{l}U X \\
U X \\
U X \\
U X \\
U X \\
U X \\
U X \\
U X \\
U X \\
U X \\
U X \\
U J \\
U X \\
U J \\
U X \\
U X \\
U X \\
U X \\
U X \\
U X \\
U X \\
U J\end{array}$ & $\begin{array}{l}0.790 \\
3.900 \\
0.790 \\
0.790 \\
0.790 \\
3.900 \\
0.790 \\
3.900 \\
0.790 \\
0.790 \\
1.600 \\
0.790 \\
0.790 \\
0.790 \\
0.790 \\
0.790 \\
3.900 \\
3.900 \\
0.100 \\
0.100 \\
0.100 \\
3.900\end{array}$ & $\begin{array}{l}0.667 \\
3.312 \\
0.667 \\
0.667 \\
0.667 \\
3.312 \\
0.667 \\
3.312 \\
0.667 \\
0.667 \\
1.337 \\
0.667 \\
0.667 \\
0.667 \\
0.667 \\
0.667 \\
3.312 \\
3.312 \\
0.088 \\
0.100 \\
0.100 \\
3.312\end{array}$ & $\begin{array}{l}0.082 \\
0.398 \\
0.082 \\
0.082 \\
0.082 \\
0.398 \\
0.082 \\
0.398 \\
0.082 \\
0.082 \\
0.169 \\
0.082 \\
0.082 \\
0.082 \\
0.082 \\
0.082 \\
0.398 \\
0.398 \\
0.033 \\
0.000 \\
0.000 \\
0.398\end{array}$ & $\begin{array}{l}M G / K G \\
M G / K G \\
M G / K G \\
M G / K G \\
M G / K G \\
M G / K G \\
M G / K G \\
M G / K G \\
M G / K G \\
M G / K G \\
M G / K G \\
M G / K G \\
M G / K G \\
M G / K G \\
M G / K G \\
M G / K G \\
M G / K G \\
M G / K G \\
M G / K G \\
M G / K G \\
M G / K G \\
M G / K G\end{array}$ \\
\hline RAD & $\begin{array}{l}C O-60 \\
C S-137 \\
U-235\end{array}$ & $\begin{array}{l}24 \\
24 \\
14\end{array}$ & $\begin{array}{l}\text { UJ } \\
\text { UJ } \\
U\end{array}$ & $\begin{array}{l}2.398 \\
4.849 \\
8.773\end{array}$ & $\begin{array}{l}U J \\
V / V \\
U\end{array}$ & $\begin{array}{r}56.616 \\
647.574 \\
458.534\end{array}$ & $\begin{array}{r}12.607 \\
152.114 \\
63.687\end{array}$ & $\begin{array}{r}13.167 \\
139.909 \\
117.350\end{array}$ & $\begin{array}{l}B Q / K G \\
B Q / K G \\
B Q / K G\end{array}$ \\
\hline
\end{tabular}

QQUALIFIER COOES:

$U=$ Compound was analyzed for but not detected.

$J=$ Indicates an estimated value.

UJ or UX = Compound was analyzed for but not detected and quantitation limit is an estimated value. See "X" description.

NJ = Tentative compound identification only and estimated concentration. No second colum confirmation of pesticides.

$x=F i s h$ tissues were held frozen while awaiting extraction. Exceeded holding time for water samples but criteria are not applicable to biological samples. Results considered valid.

$V / V=$ Indicates that the result has been verified and is a valid result . 
Appendix $\mathbf{H}$

CONSERVATIVE SCREENING OF THE DETECTABLE CONTAMINANTS DATA BASE FOR CARCINOGENS AND NONCARCINOGENS 

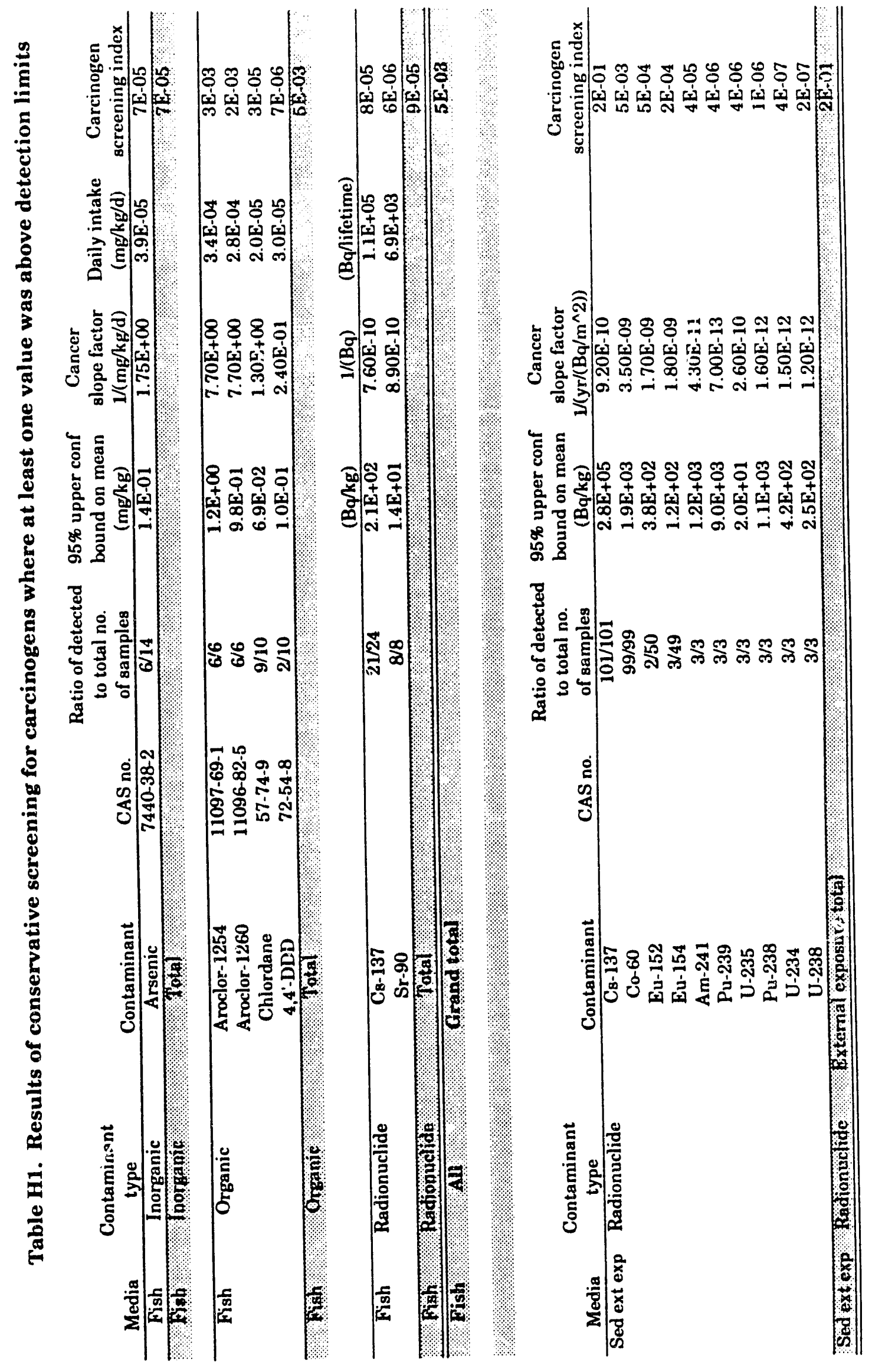


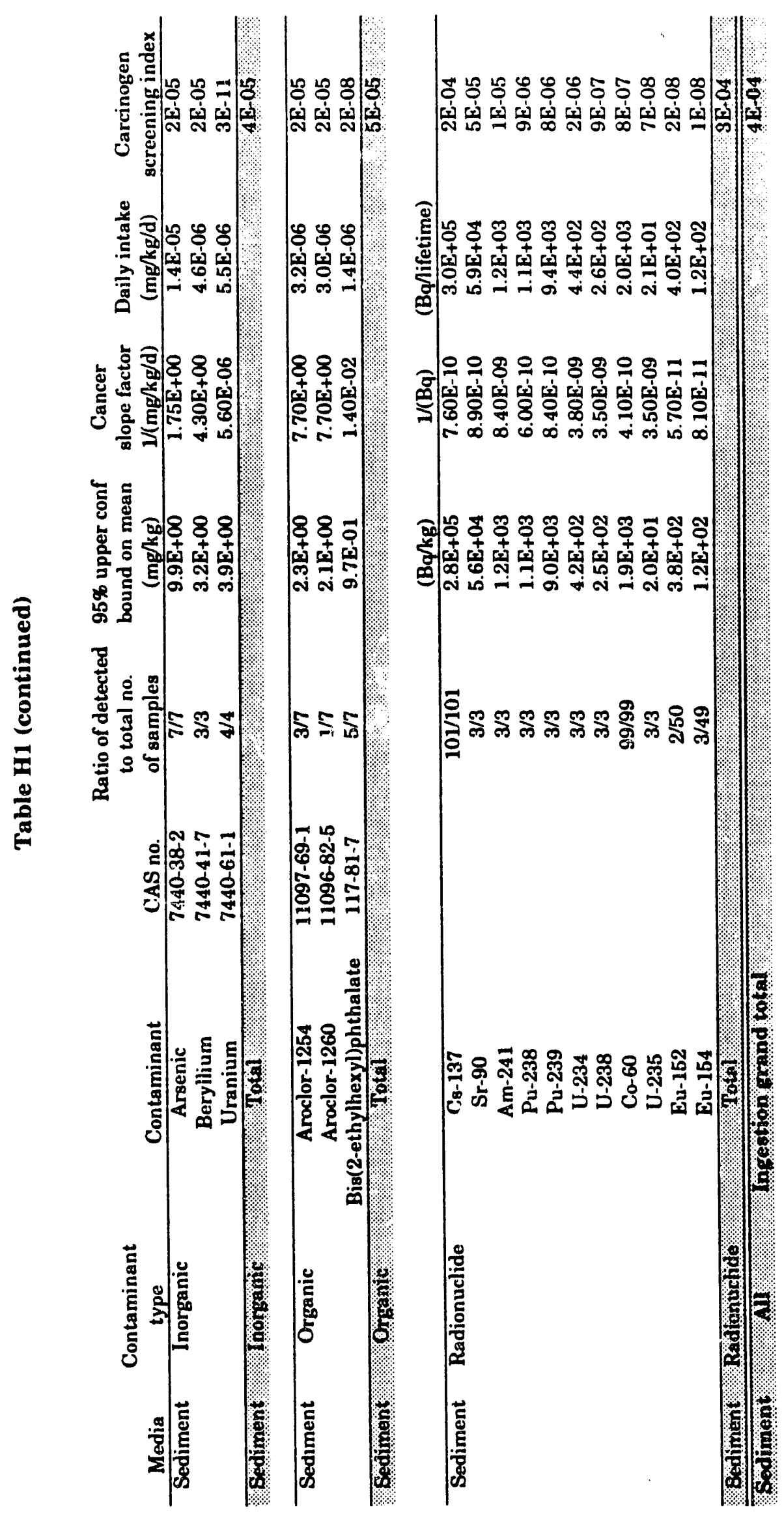


105

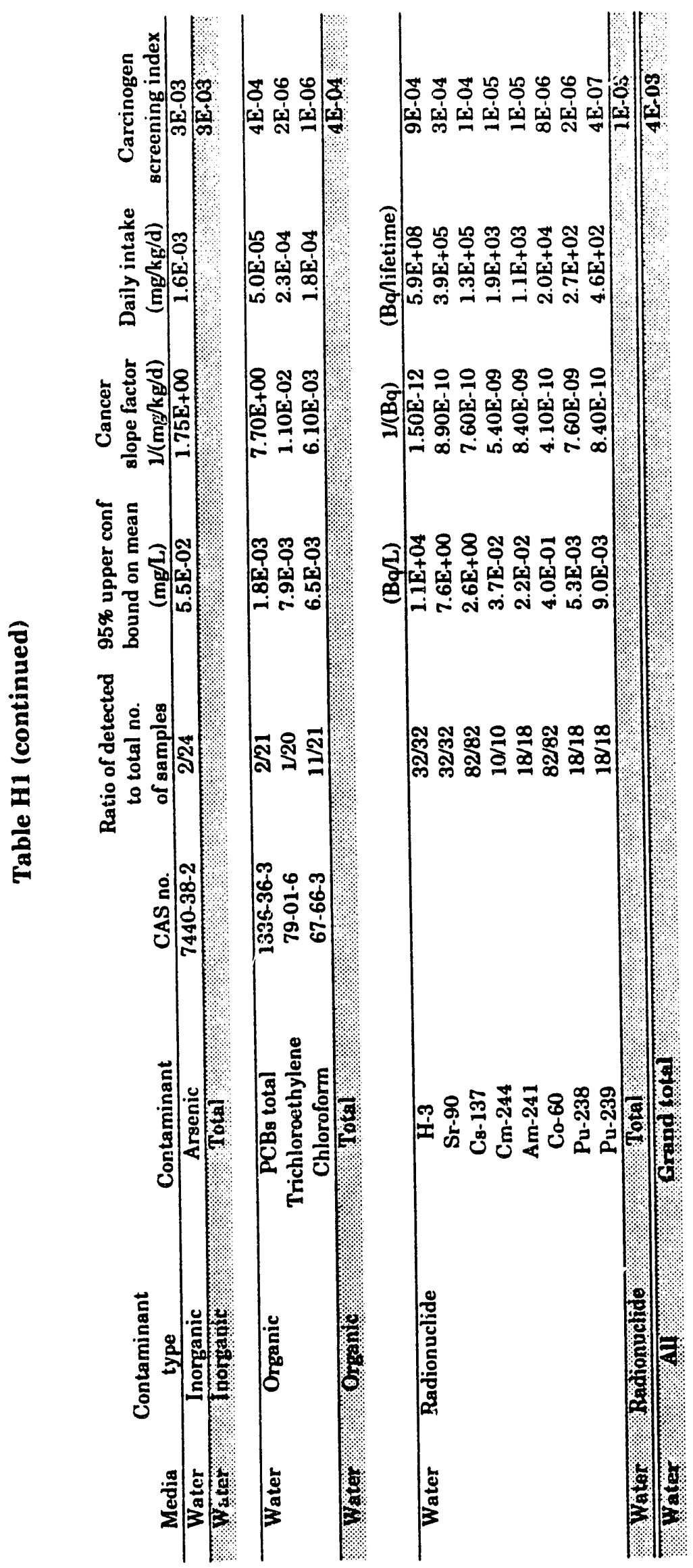


ב.

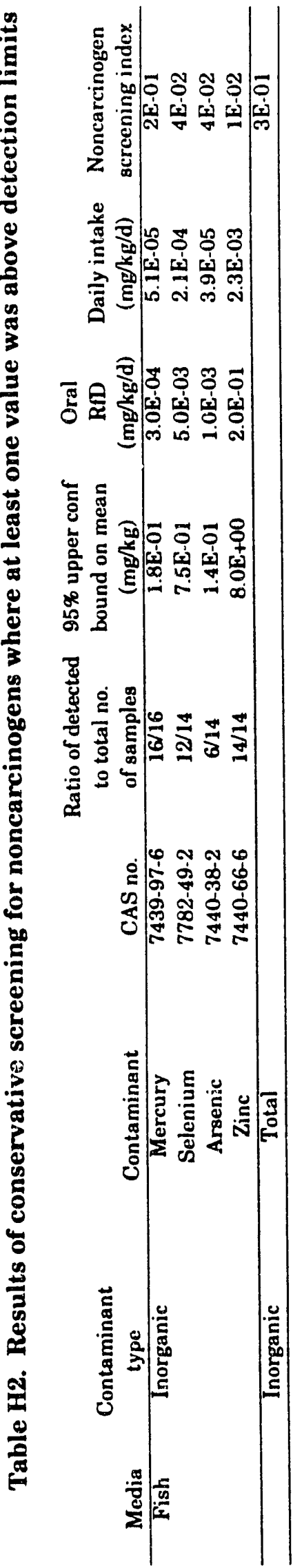

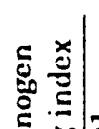

든

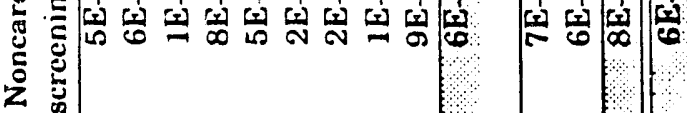

이 ल)

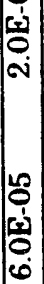

竞

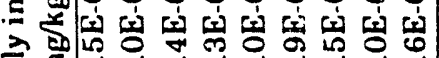

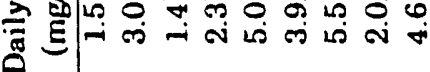

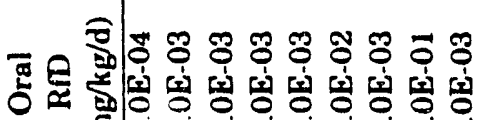
हा ம

둥

每

ะ

ล

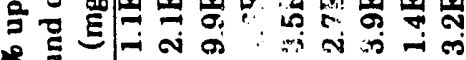

용

马

o 10

造

ミミミミミミฟ゙矛 今

2.

.

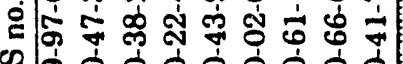

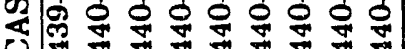

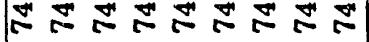

ஜ 묄 면 चั

ธี ซี 될 oi $\infty$

6 8 乐 के का ब. 55

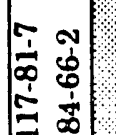

$\cong \frac{1}{\infty}$

竎

를

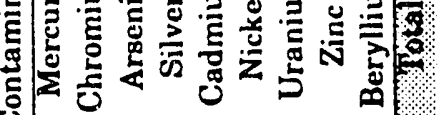
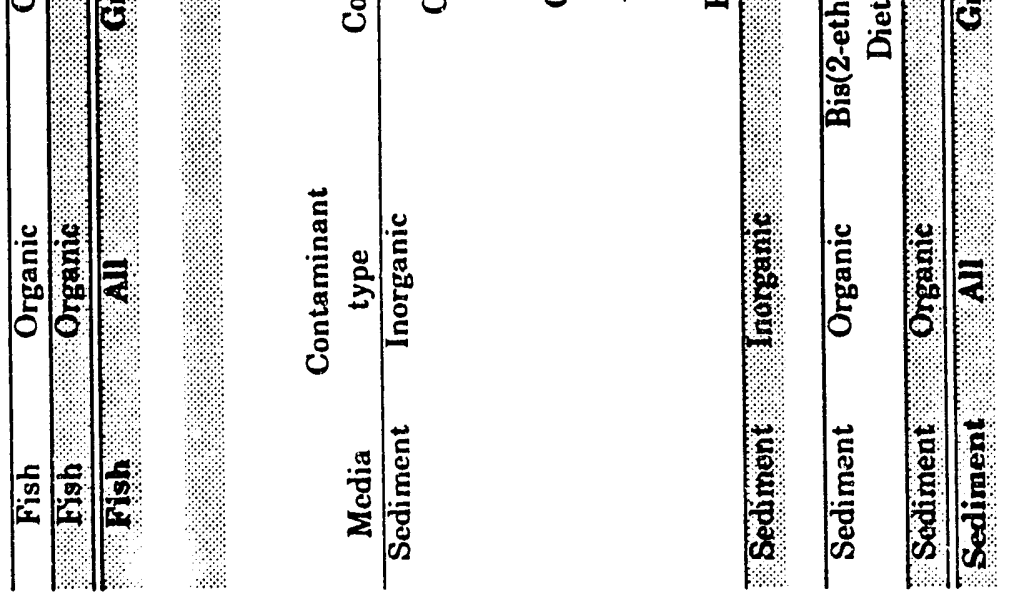


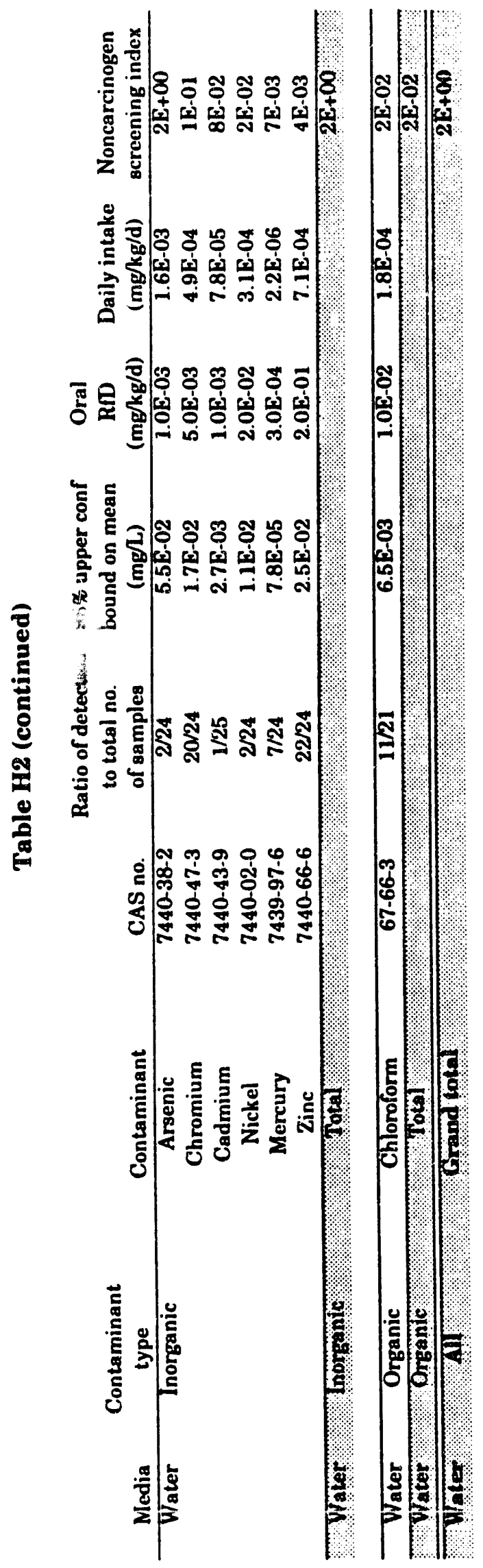


Appendix I

NONCONSERVATIVE SCREENING OF THE DETECTABLE CONTAMINANTS DATA BASE FOR CARCINOGENS AND NONCARCINOGENS 

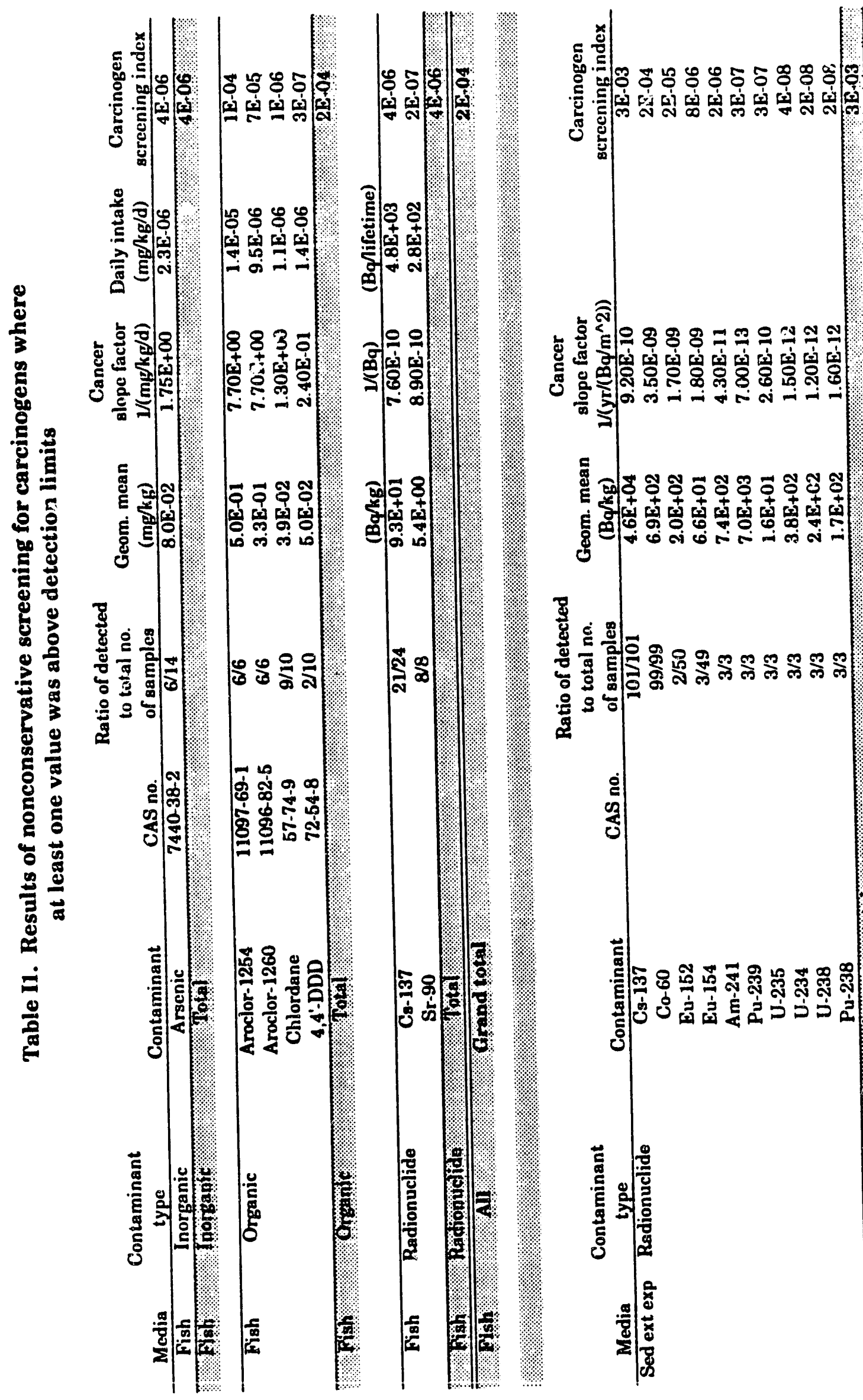
옳

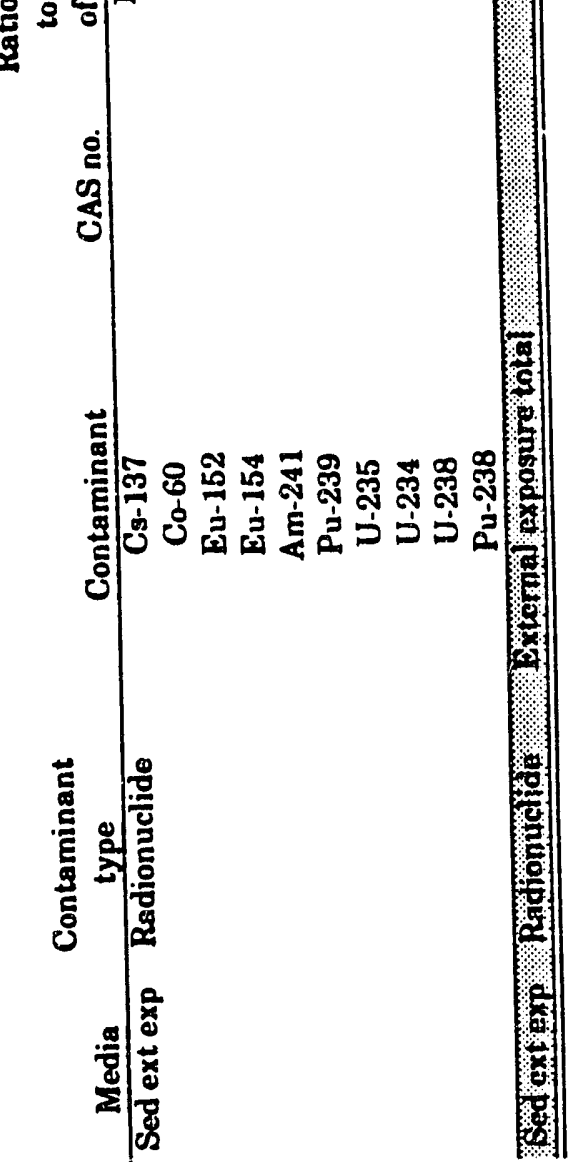




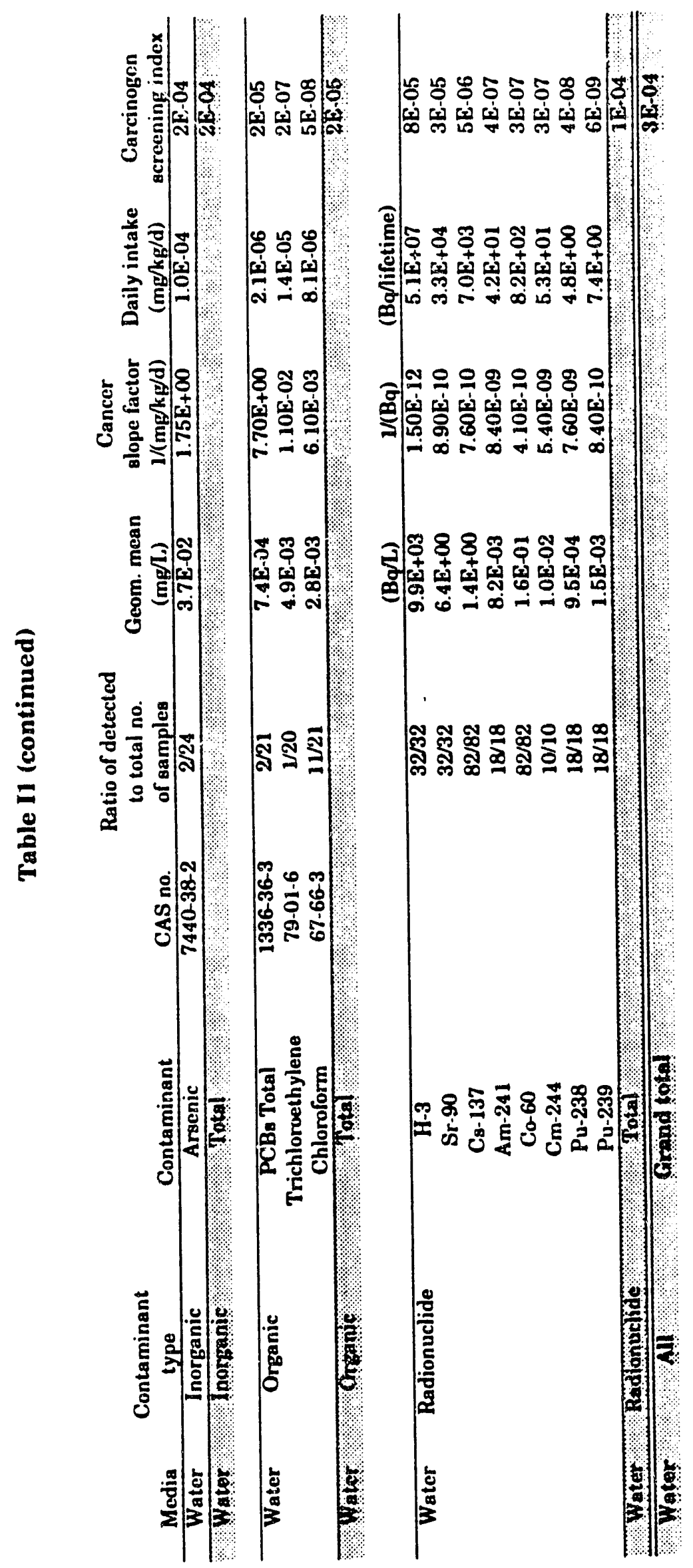




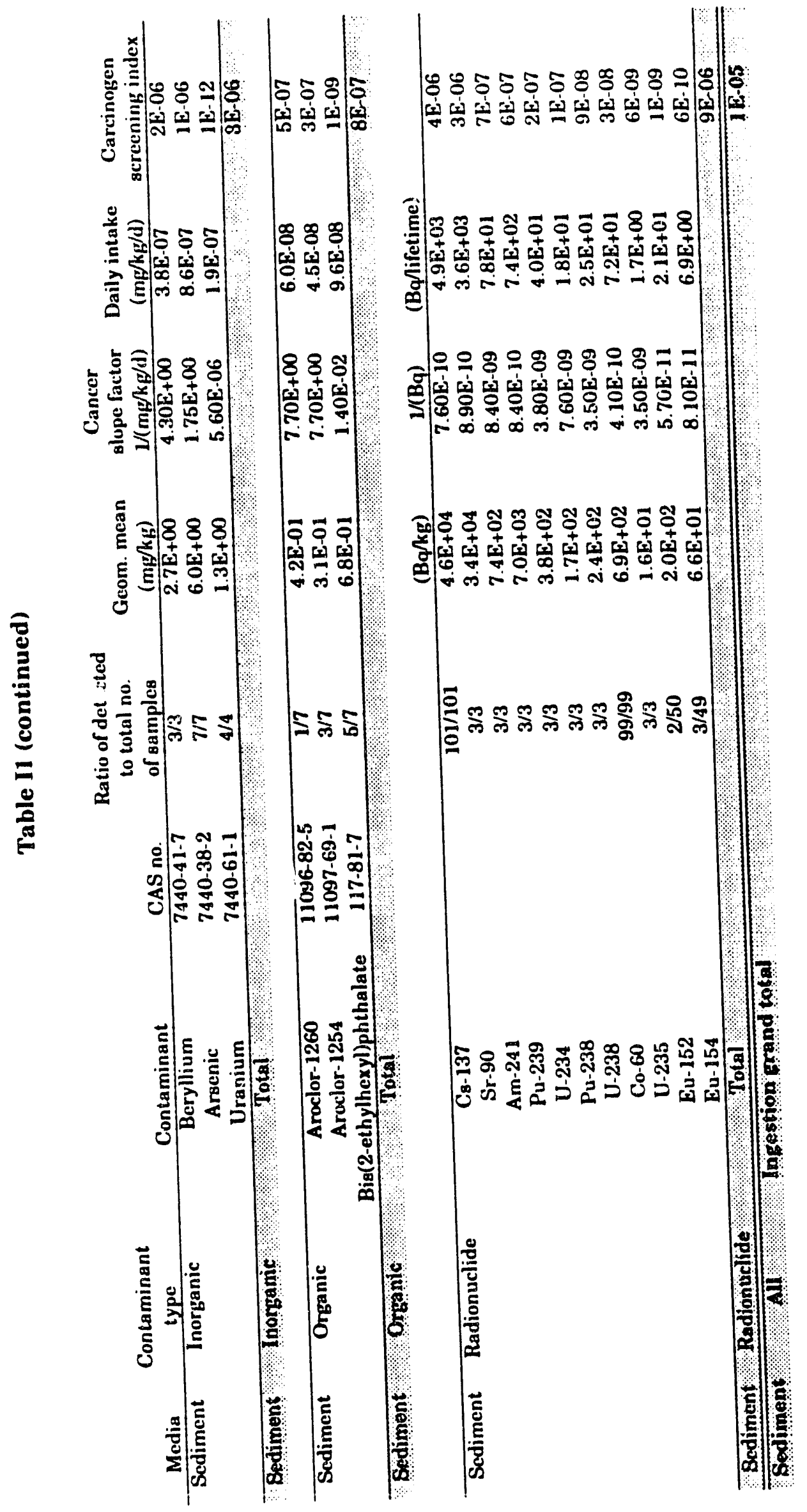




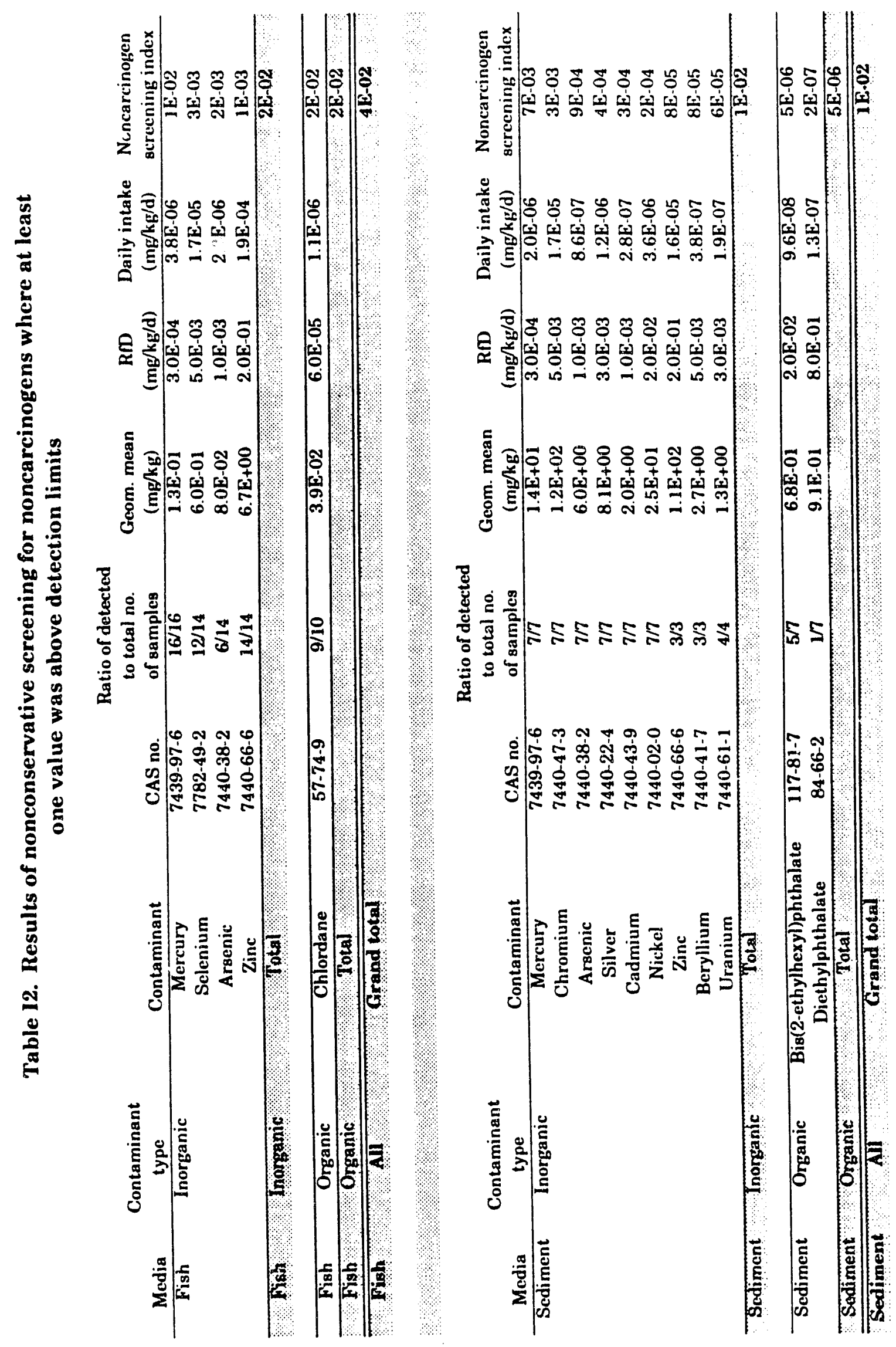




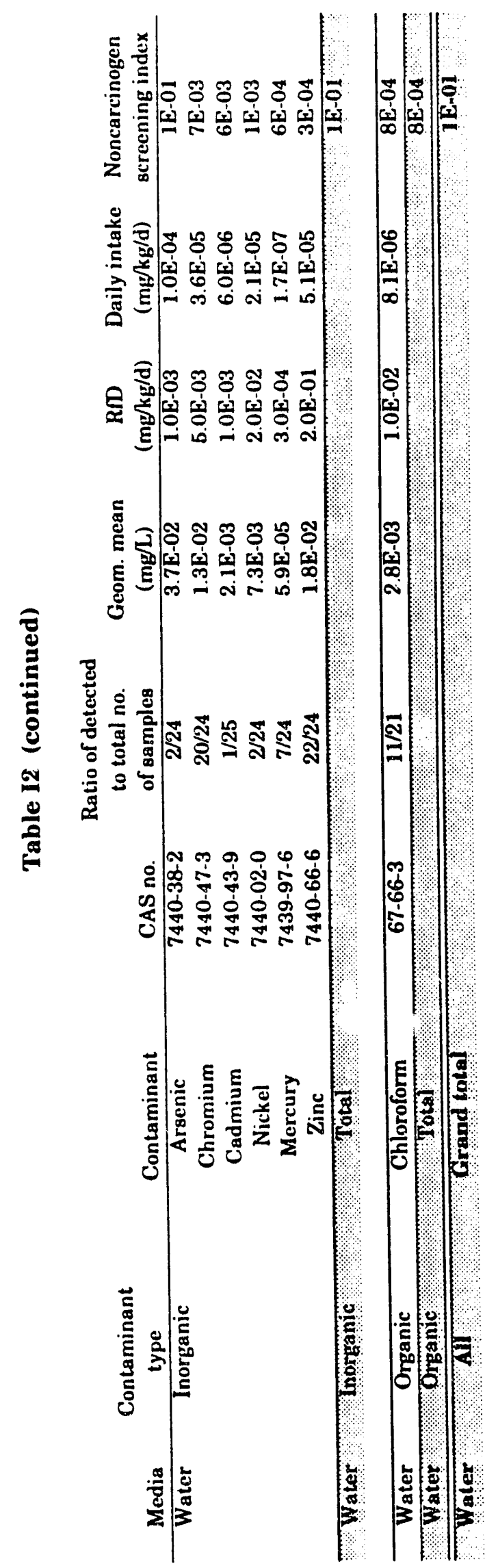




\section{Appendix J}

SCREENING OF THE INTRUDER SCENARIO FOR DETECTED

CARCINOGENS AND NONCARCINOGENS 


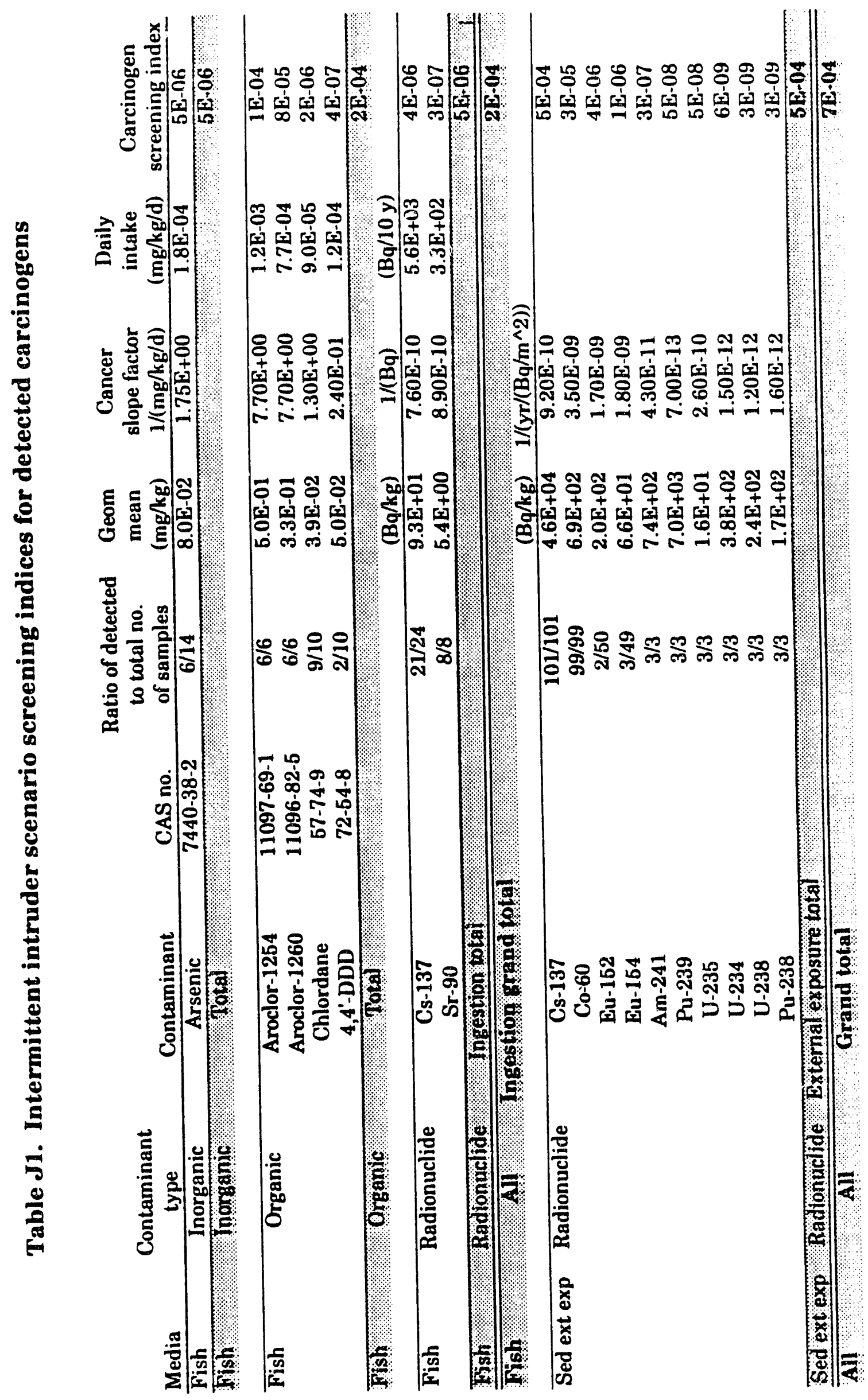




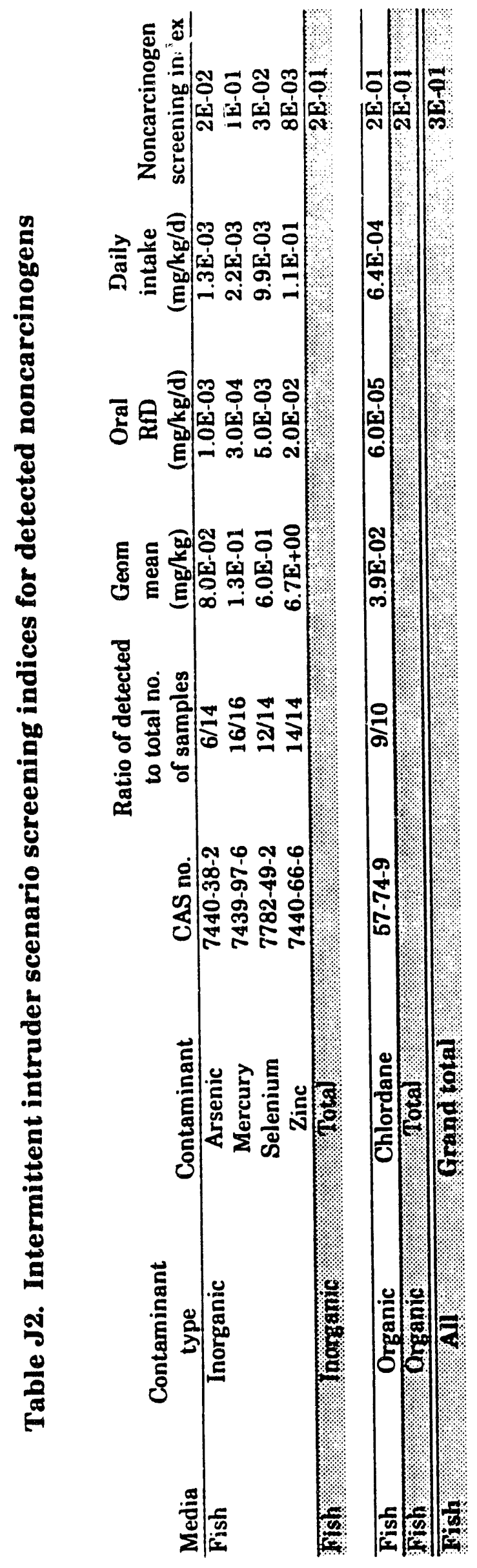


Appendix K

CONSERVATIVE SCREENING OF THE NONDETECTABLE CONTAMINANTS DATA BASE FOR CARCINOGENS

AND NONCARCINOGENS 


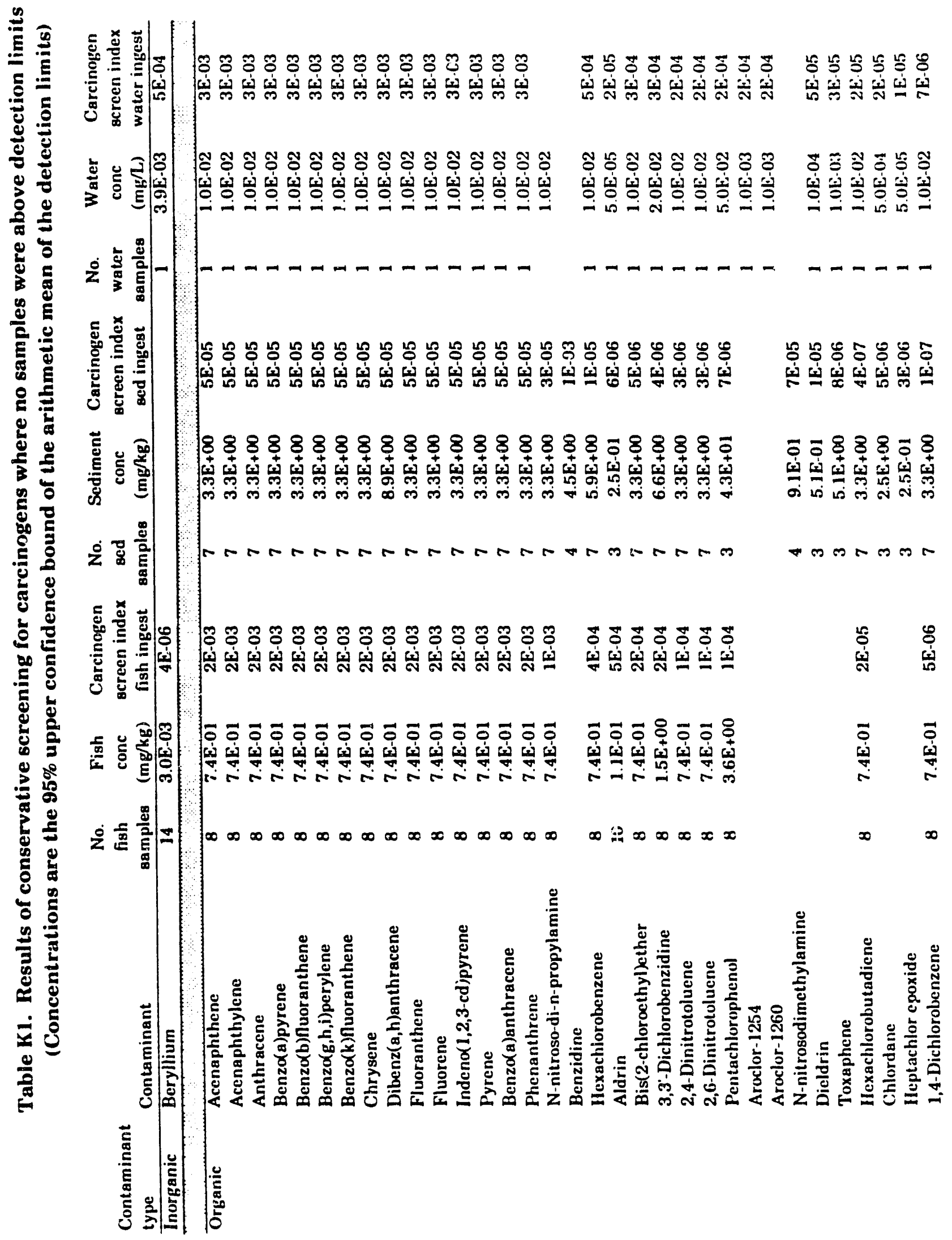




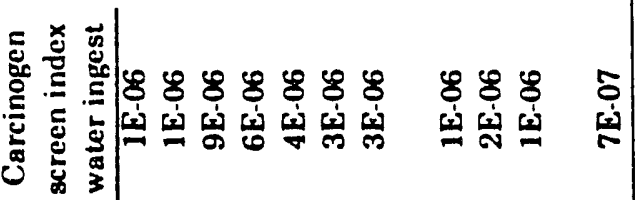

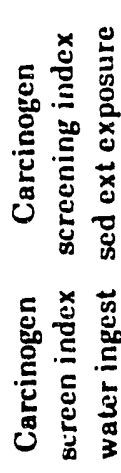

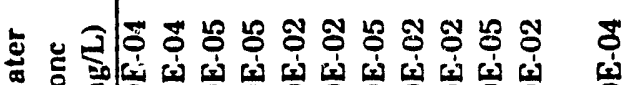

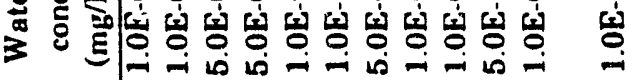

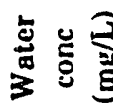

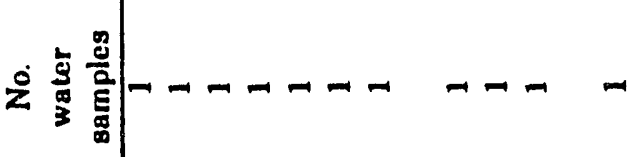

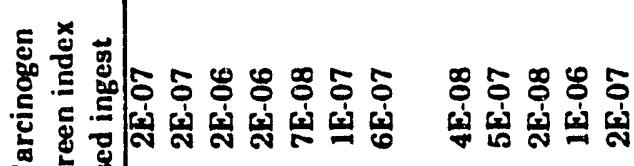
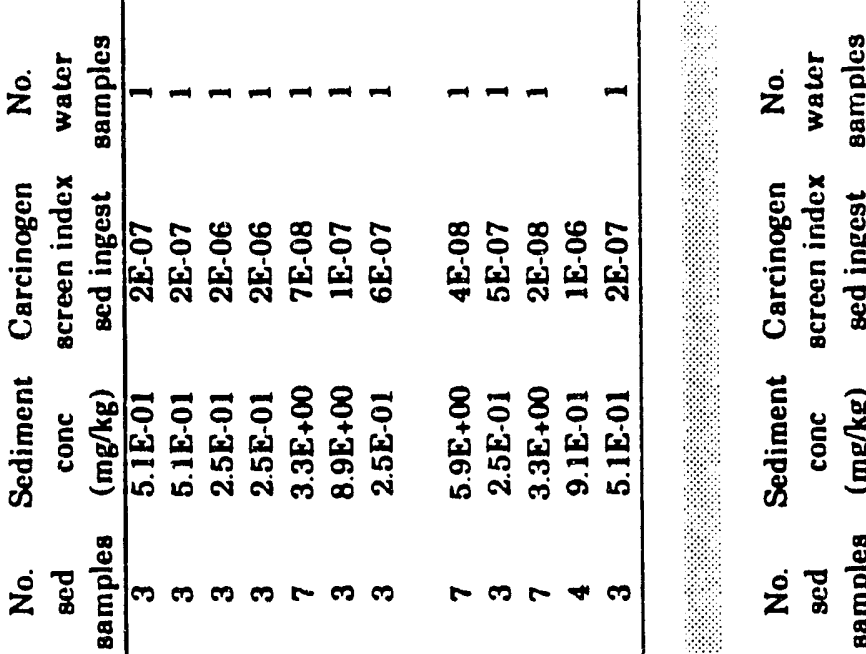

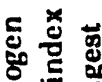

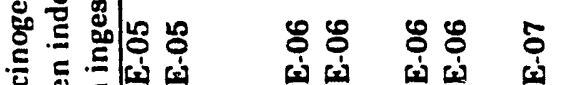

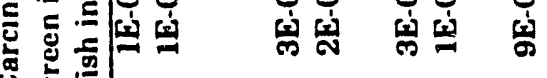

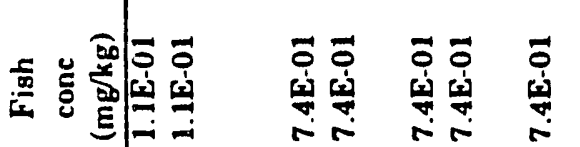

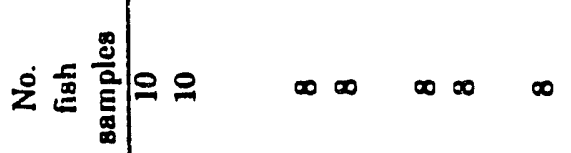
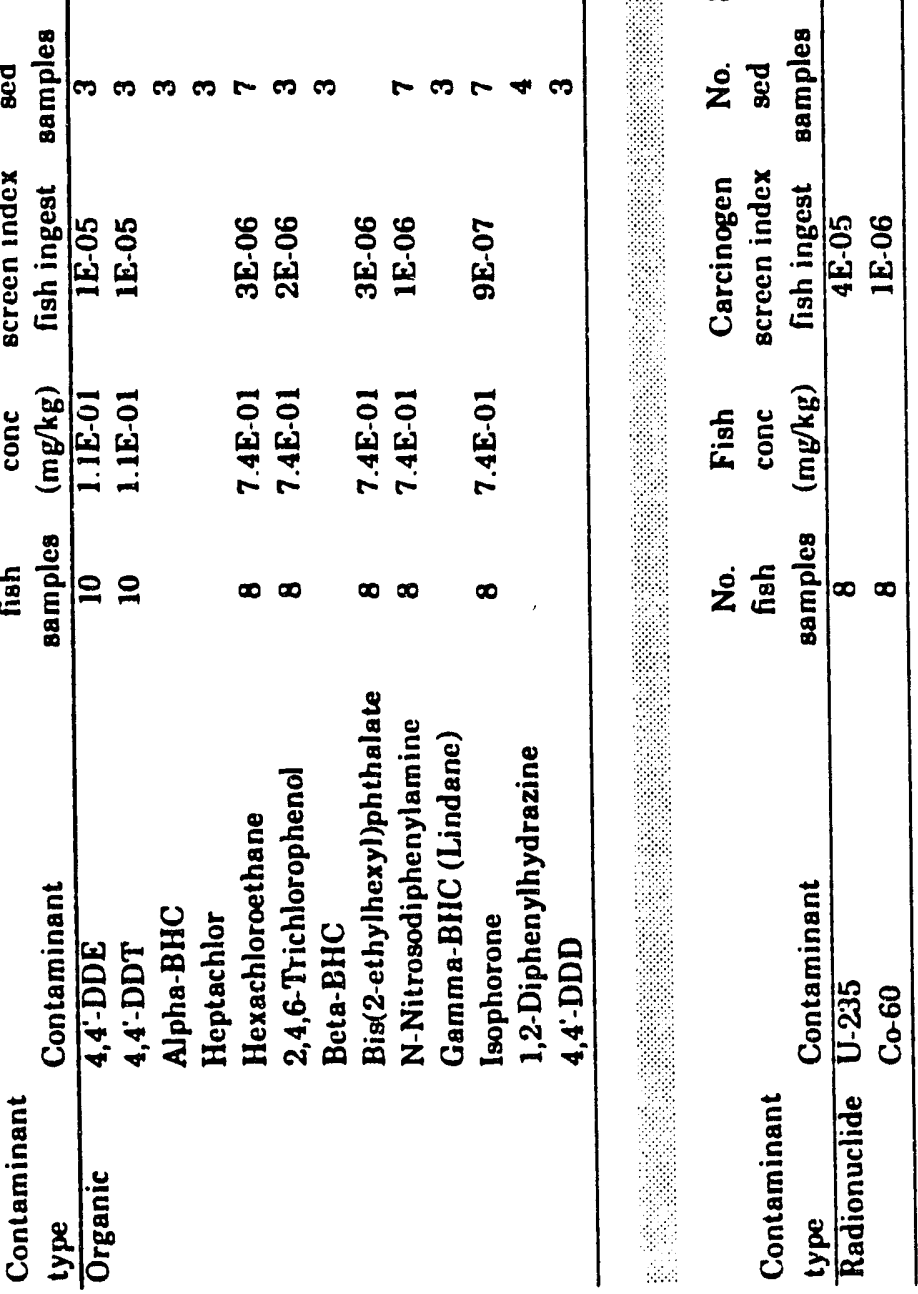


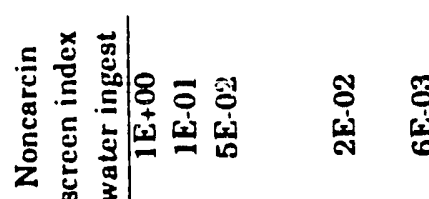

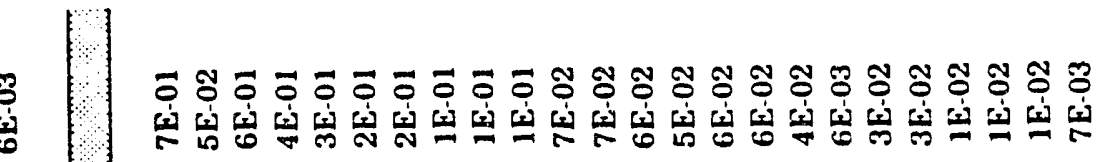

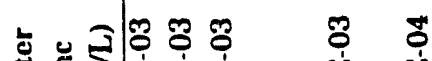

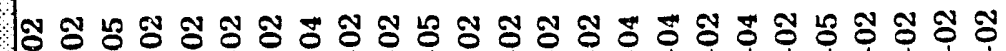
३

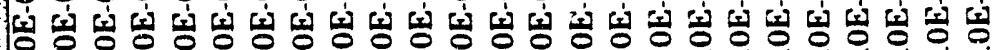

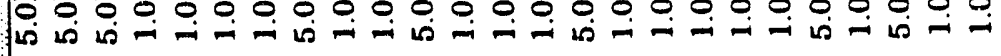

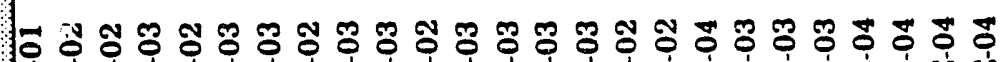

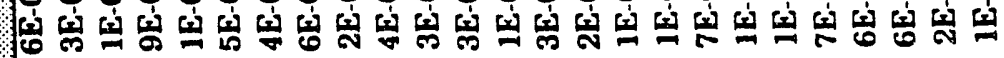

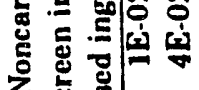

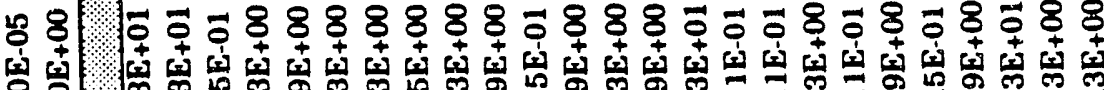

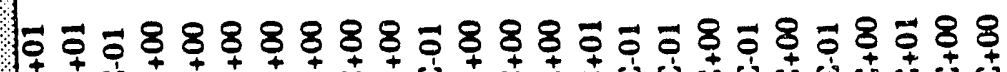
를 ช $\because$ O

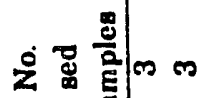

משn

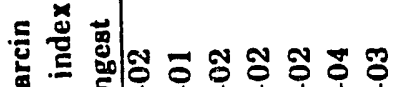

政.

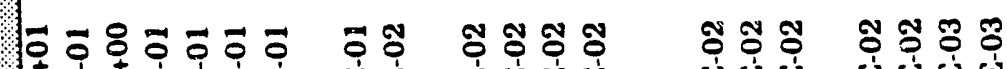

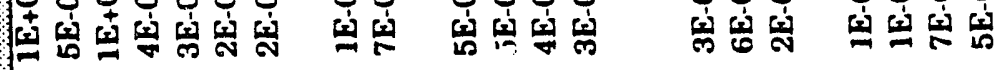

之总焉

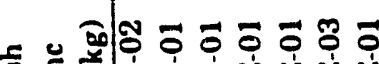

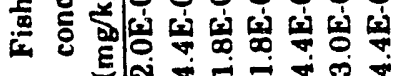

ठ유

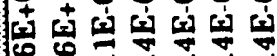

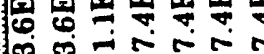

후 $\overline{0} \overline{0} \overline{0}$

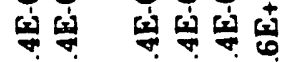

ธีอ

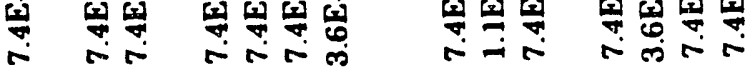

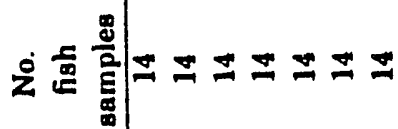

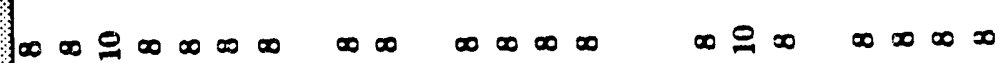

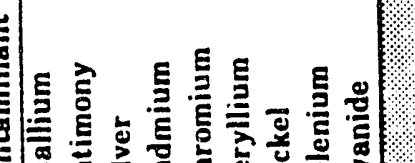




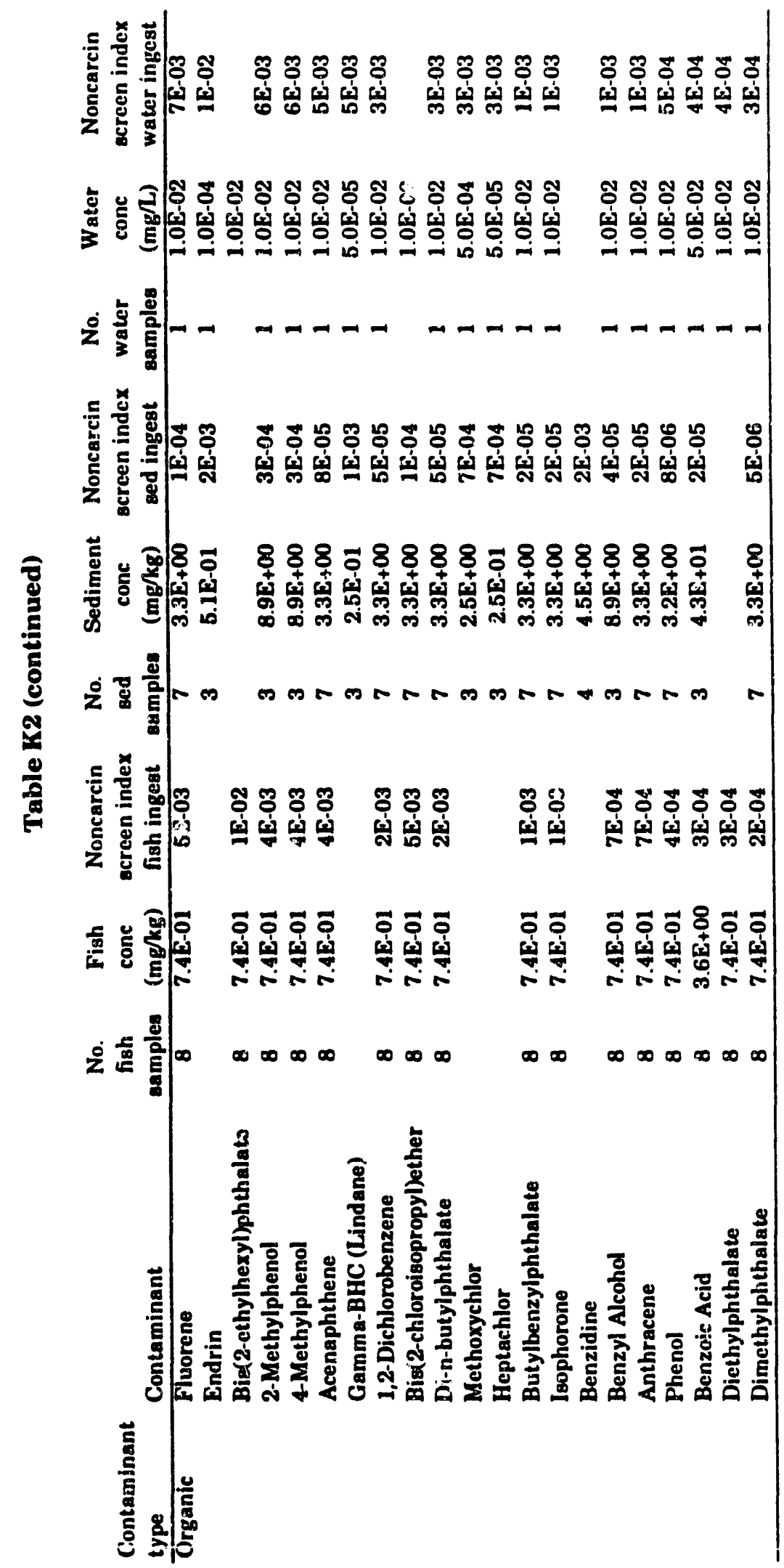


Appendix L

NONCONSERVATIVE SCREENING OF THE NONDETECTABLE CONTAMINANTS DATA BASE FOR CARCINOGENS

AND NONCARCINOGENS 


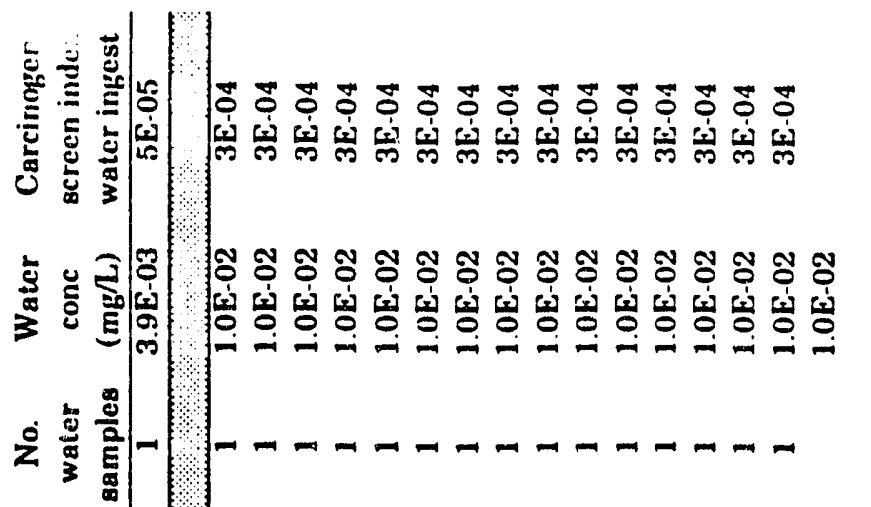

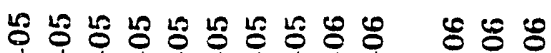

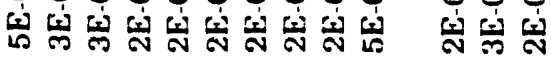

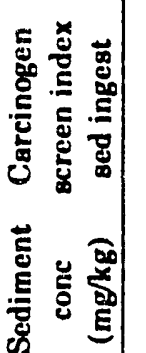

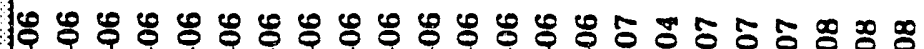

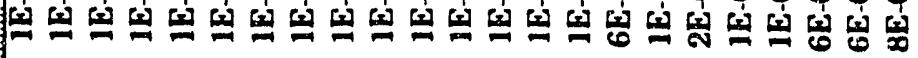

䆑 중

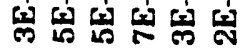

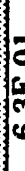

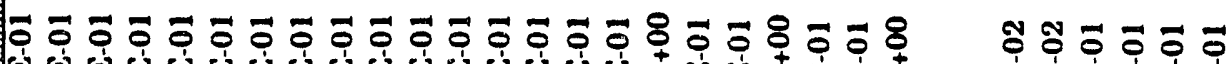
ஸ் 之 ت $-$ $r a$ ᄃ

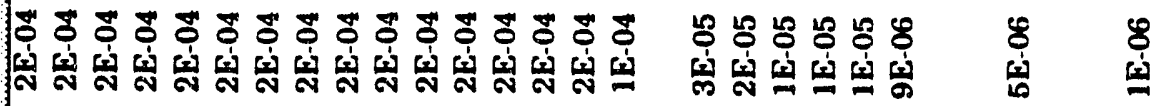

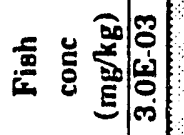

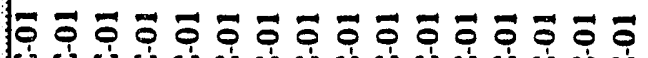

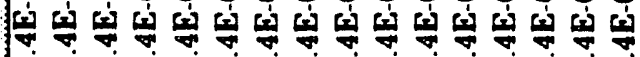

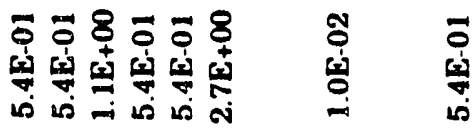

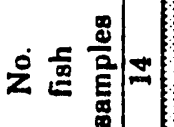

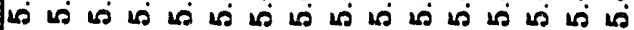
$\infty \infty \infty \infty \infty \quad \stackrel{0}{=} \quad \infty$

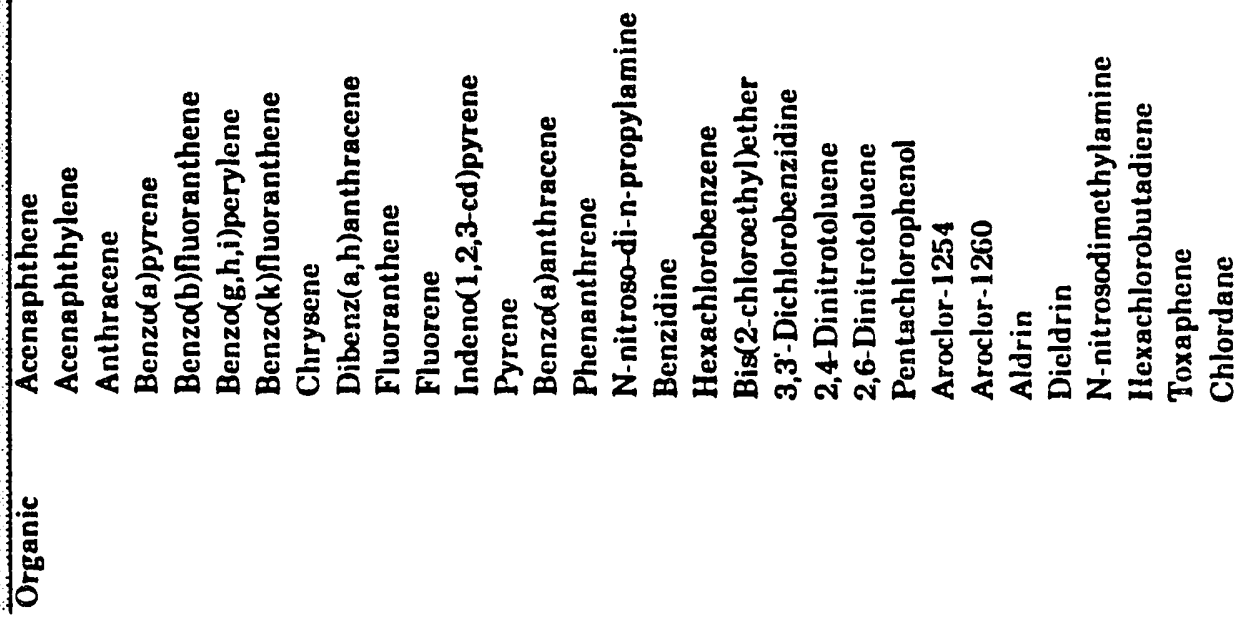




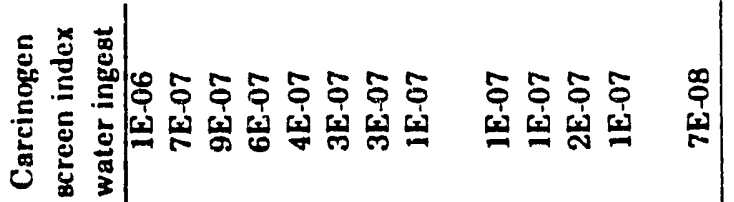

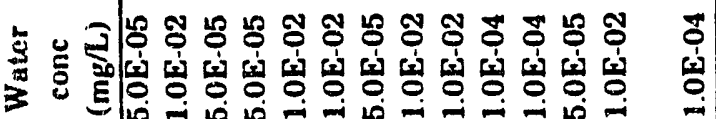

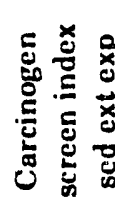

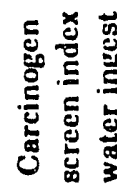

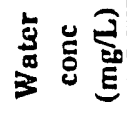

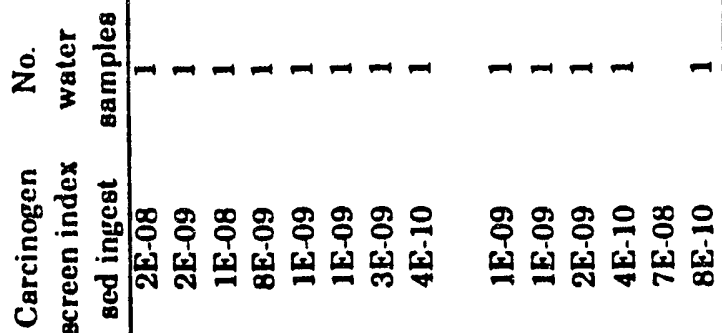

है

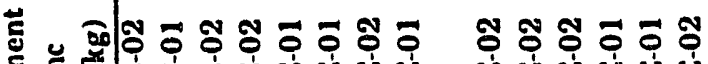

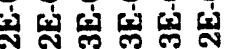
हु E E

$\dot{z} \frac{\mathrm{e}}{3}$

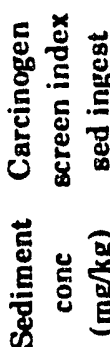

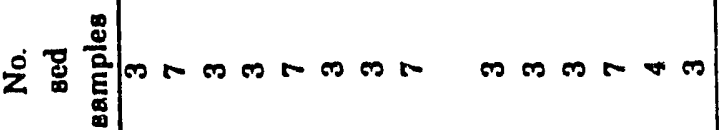

总总

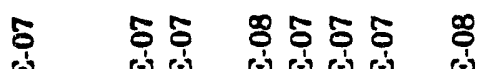

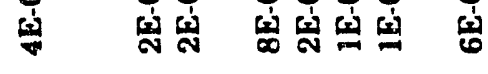

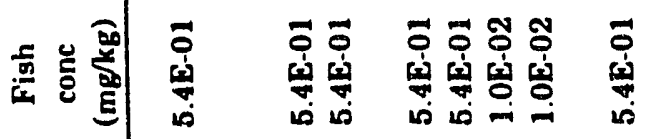

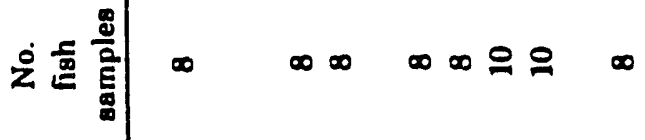

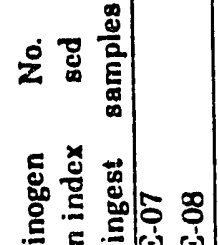

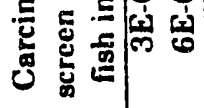

要旨尊

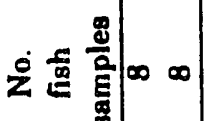
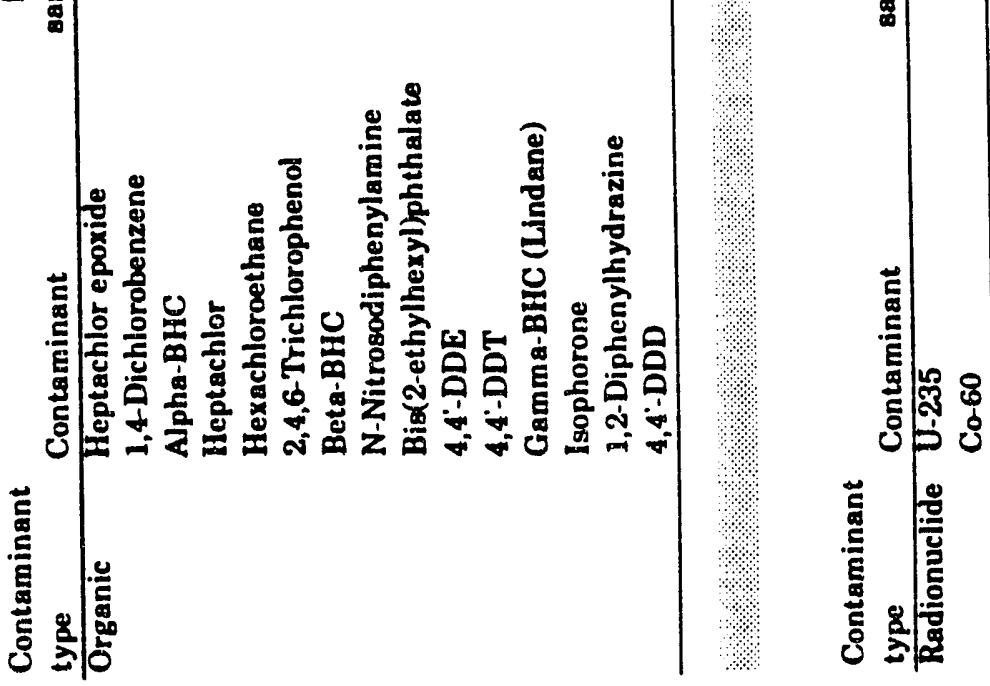


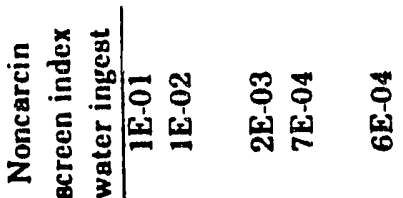

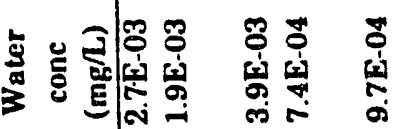

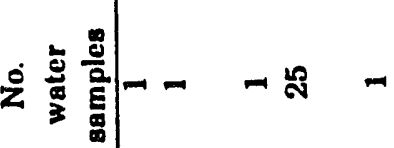

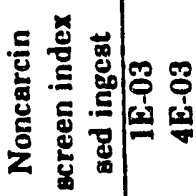

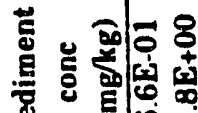
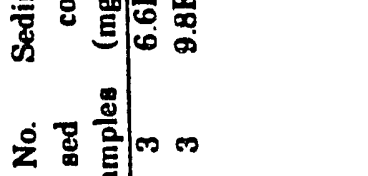

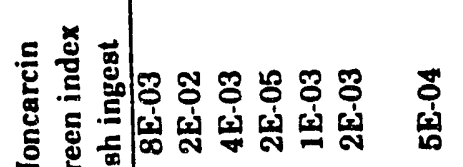

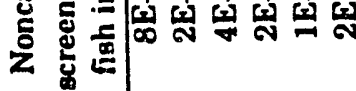

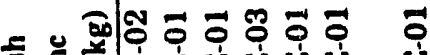

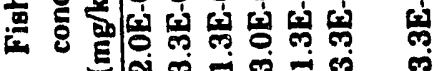

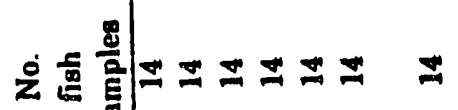

ำำ

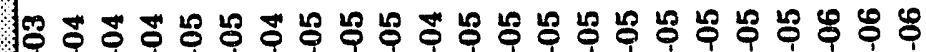

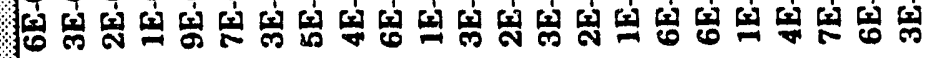

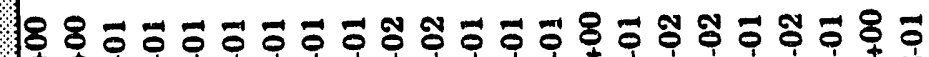

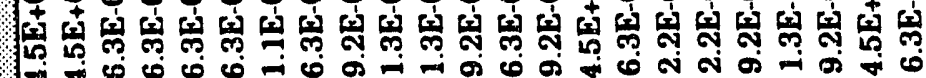

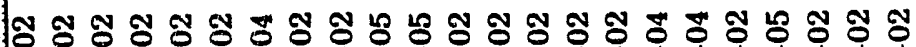

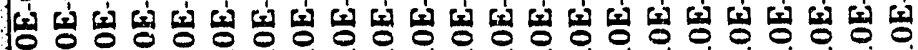

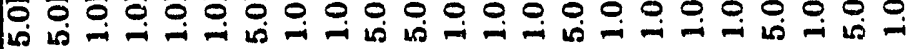

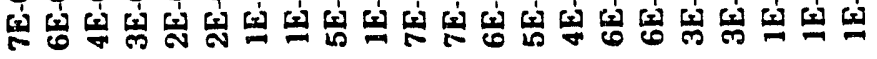

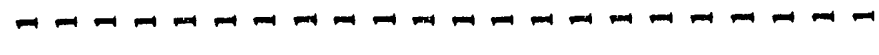
-

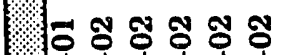

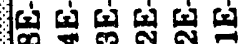

ชั ช ช

\% $8 \%$

\%

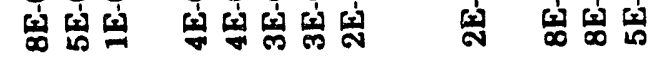

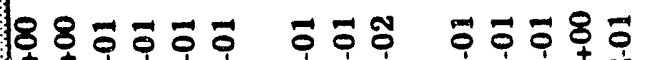

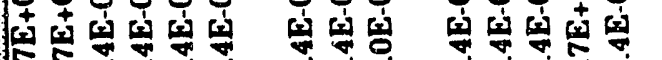

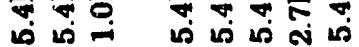

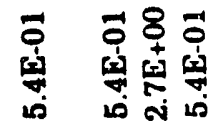
बi่ ง

$\infty \infty$ 에 $\infty \infty \infty \infty \infty \infty \infty$ 


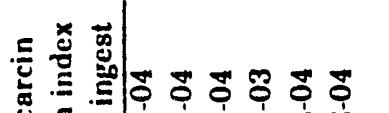

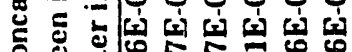

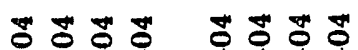

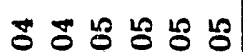

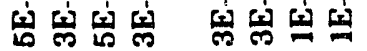

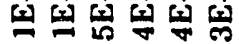

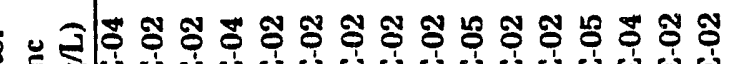

ชิ ชิ ชิ ชิ ชิ ชี

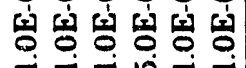

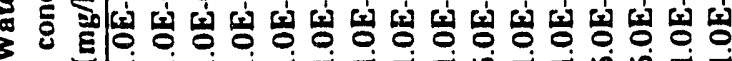
z 总

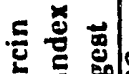

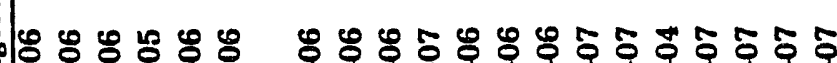

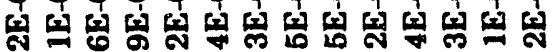

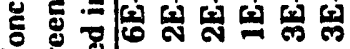
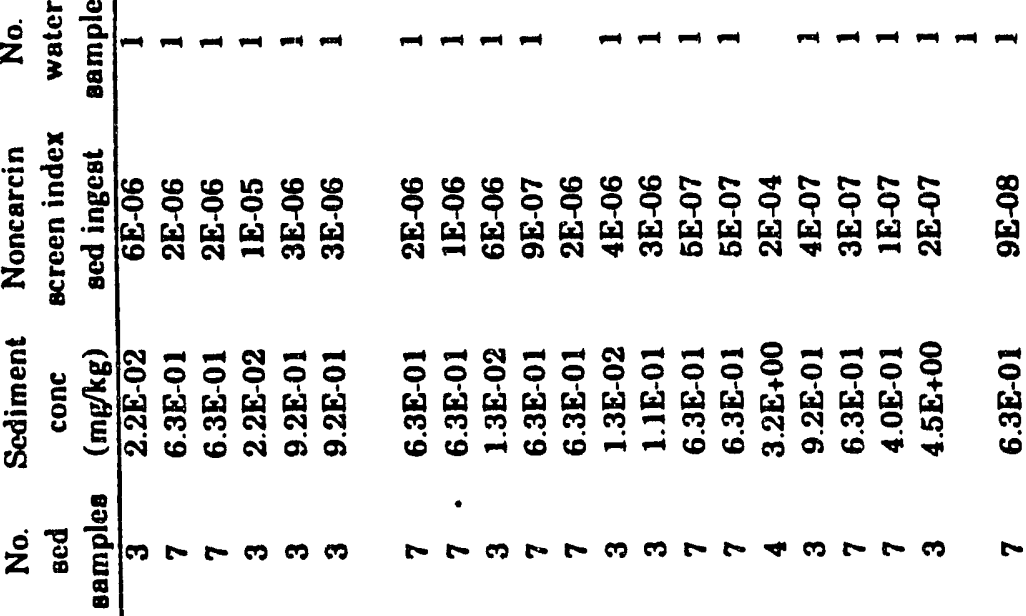

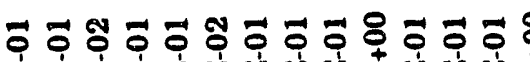

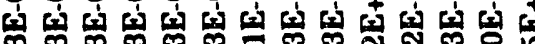
Еّ

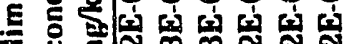

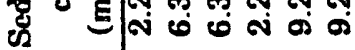

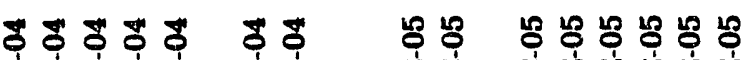

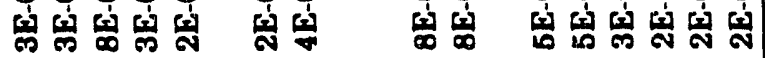

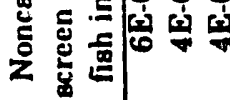

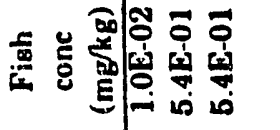

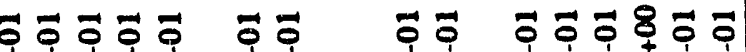

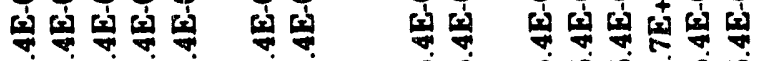

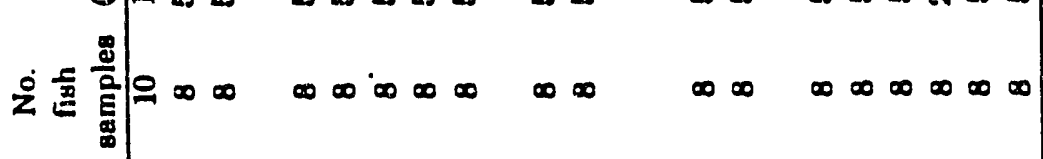

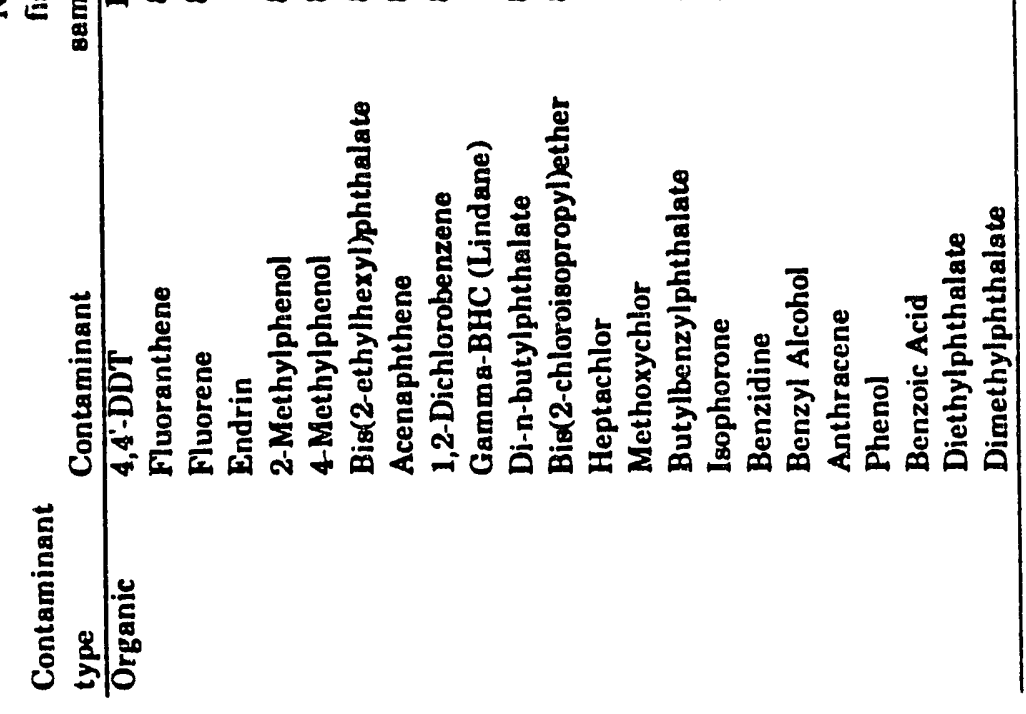


Appendix M

CLASSIFICATION OF SEDIMENT WASTE FROM WHITE OAK CREEK EMBAYMENT BY TOXICITY CHARACTERISTIC LEACHATE PROCEDURE 


\section{INTRODUCTION}

Waste management concerns associated with construction of the White Oak Creek Embayment (WOCE) sediment-retention structure have focused on radiological contaminants; however, WOCE sediment also contains elevated levels of inorganic contaminants (Tables C1 and $\mathrm{C2}$ ). Based on the concentrations of the contaminants present in the sediment, there is a potential for waste generated from the sediment to be classified as mixed waste. Such a classification would greatly increase the effort necessary to manage the waste created by the construction of the retention structure. Therefore, sediment from the embayment was subjected to a Toxicity Characteristic Leachate Procedure (TCLP) to determine whether the sediment should be classified as mixed waste. The TCLP is required by the U. S. Environmental Protection Agency (EPA) for the classification of waste (Sect. V of 40 CFR Parts 261, 264, 265, 268, 271, and 302; Federal Register Vol. 55, No. 61, March 29, 1990, pp. 11846). A discussion of the TCLP, including methods, regulated constituents and regulatory levels, is given in Federal Register, Vol. 55, No. 61, March 29, 1990, pp. 1179811877.

\section{METHODS}

Prior to performing the TCLP, samples were screened by comparing the levels of inorganic or organic contaminants detected by conventional analyses (atomic absorption plus inductively coupled plasma for inorganic and gas chromatograph plus gas chromatograph/MS for organic analytes) with guidance values. If the concentrations in dried sediment were above or close to the guidance level, the TCLP was performed on the material. The location of sites in the embayment from which samples were collected to perform the TCLP are shown in Fig. M1.

\section{RESULTS}

Results from conventional analytical methods from samples taken in the same area of lower WOCE as the TCLP samples indicate that the maximum concentration for mercury $(27.4 \mu \mathrm{g} / \mathrm{g}$ dry sediment) from a depth of 8 to $12 \mathrm{~cm}$, was above the TCLP guidance level but well below any level of concern for human health (Tables $\mathrm{C} 1$ and $\mathrm{C2}$ ). Four other inorganics (cadmium at $2.8 \mu \mathrm{g} / \mathrm{g}$ ) (Tables $\mathrm{C} 1$ and $\mathrm{C} 2$ ) had maximum concentrations that were within $10 \%$ of the TCLP guidance levels at a depth of 4 to $8 \mathrm{~cm}$, which corresponds to ${ }^{137} \mathrm{Cs}$ peak values. TCLP results for arsenic and mercury in samples collected April 1, 1991, had at least one value greater than $10 \%$ of the guidance value; however, none of the TCLP results for inorganics approached the guidance values (Table M1). No trends in concentrations of inorganics were detected which could be associated with changes in ${ }^{137} \mathrm{Cs}$ concentrations or with sediment depth. Because all values obtained from the TCLP were below guidance values, any sediment waste generated by the construction of the retention structure should not be classified as mixed waste. 


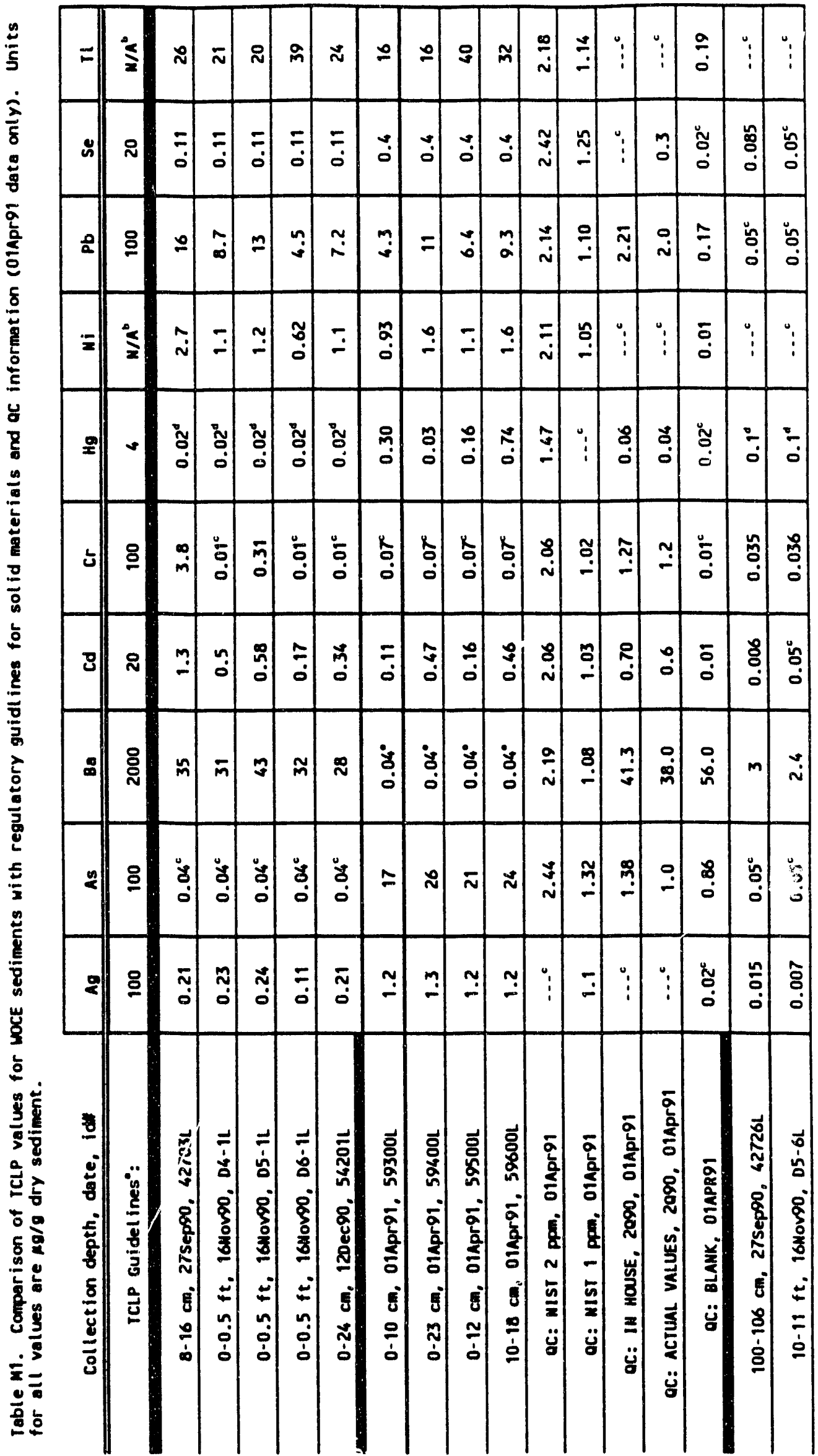




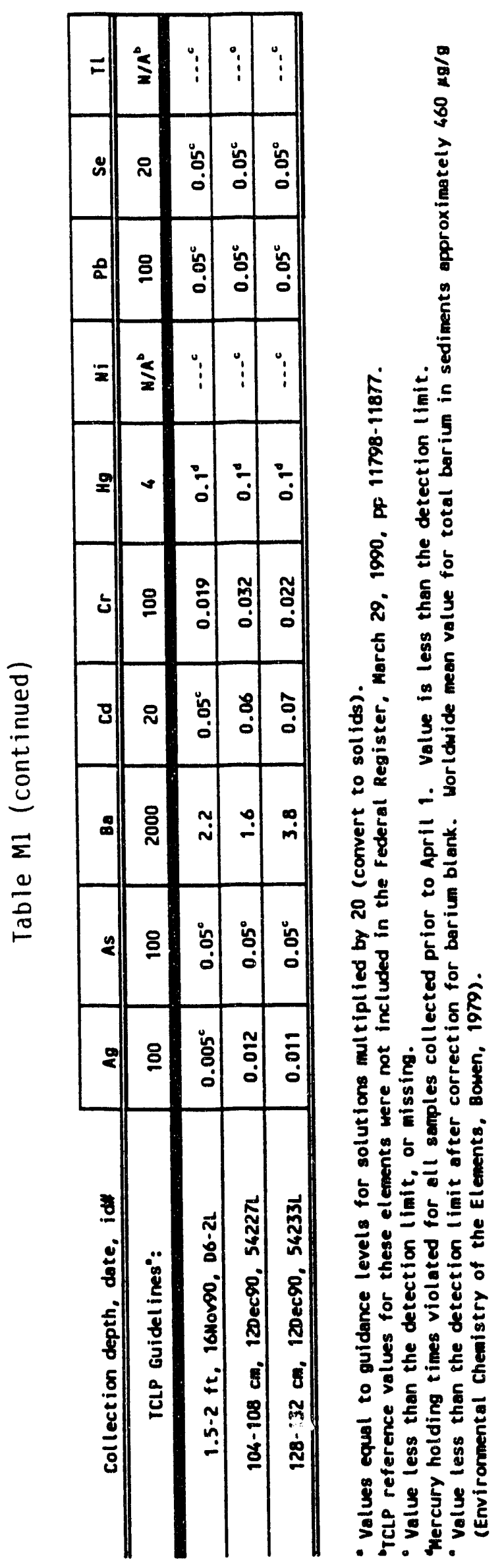




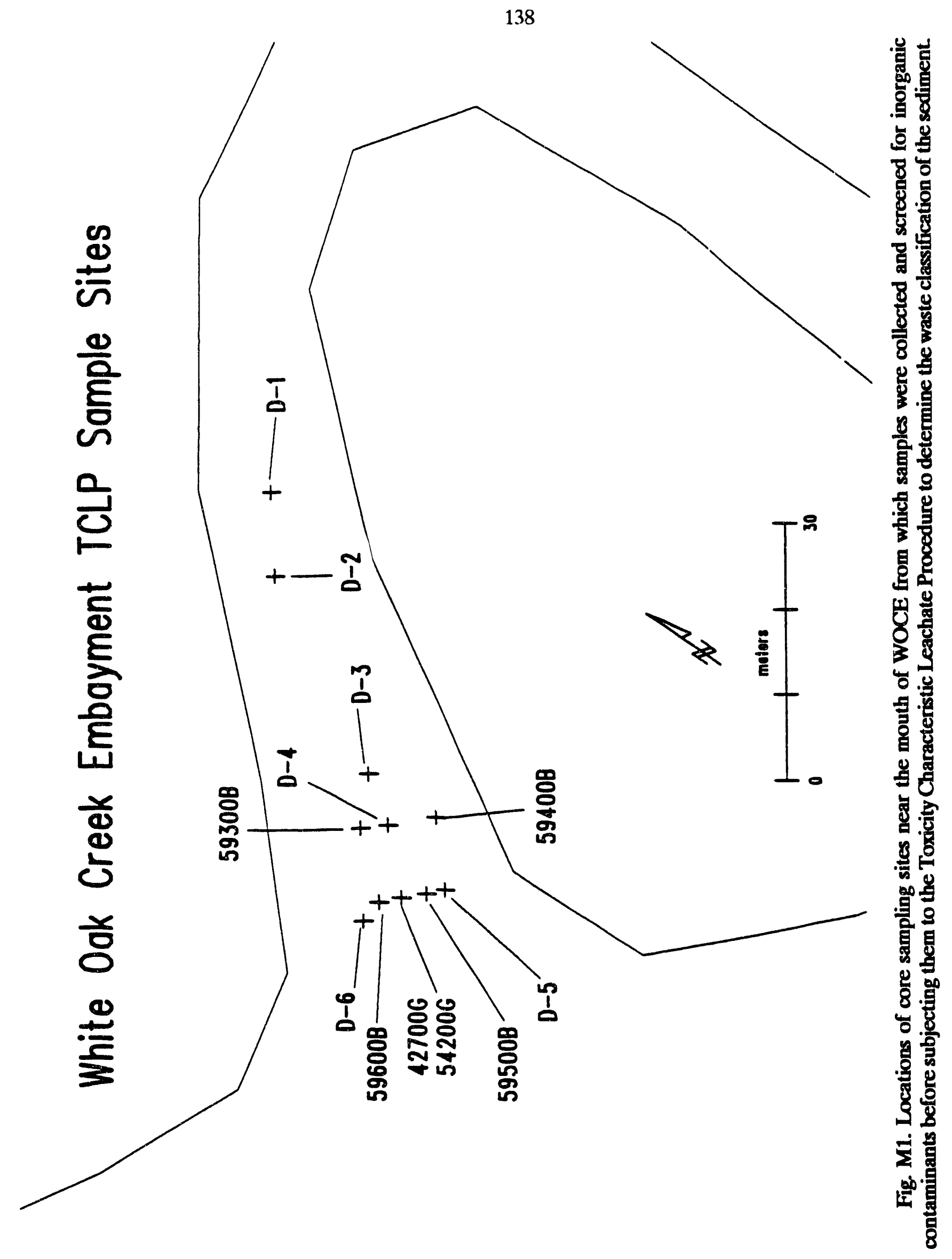


ORNL/ER-81

\section{DISTRIBUTION}

1. L. D. Bates

2. D. T. Bell

3. B. G. Blaylock

4. R. B. Cook

5. M. F. P. DeLozier

6. N. W. Durfee

7. J. T. Etheridge

8. C. J. Ford

9. M. L. Frank

10. S. B. Garland

11. C. W. Gehrs

12. C. D. Goins

13 P. J. Halsey

14. F. O. Hoffman

15. R. O. Hultgren

16. K. G. Kahl

17. B. L. Kimmel

18. T. M. Koepp

19. F. C. Kornegay

20. E. H. Krieg

21. J. R. Lawson

22. D. M. Matteo
23. J. R. Merriman

24-25. P. T. Owen

26. F. S. Patton

27. M. W. Rosenthal

28. T. H. Row

29. G. E. Rymer

30. S. D. Van Hoesen

31. R. I. Van Hook

32. D. Watkins

33. R. K. White

34. R. Williams

35. P. Wood

36. Central Research Library

37. Environmental Sciences Division Library

38. Clinch River Program Document Management Center

39-43. ER Document Management Center-RC

44. ORNL Laboratory Records

45. Office of Assistant Manager for Energy Research and Development, Department of Energy Oak Ridge Field Office, P.O. Box 2001, Oak Ridge, Tennessee 37831-8600

46-48. J. Bilyeu, Department of Energy, Office of Environmental Restoration, Eastern Area D\&D Branch, EM-423 (GTN), Washington, DC 20545

49-51. M. Ferre, Department of Energy Oak Ridge Field Office, P. O. Box 2001, Oak Ridge, TN 37831-8541

52. C. S. Gist, Department of Energy Oak Ridge Field Office, P.O. Box 2001, Oak Ridge, TN 37831-8541

53. Mary Leslie, CDM Federal Programs, 800 Oak Ridge Turnpike, Oak Ridge, TN 37830

54. Richard Nace, Branch Chief, Nonenrichment Facilities, Oak Ridge Program Division, Office of Eastern Area Programs, Office of Environmental Restoration, EM-423, Trevion 2, U.S. Department of Energy, Washington, DC 20585

55-57. D. G. Page, Department of Energy Oak Ridge Field Office, P.O. Box 2001, Oak Ridge, TN 37831-8541

58-60. R. C. Sleeman, Department of Energy Oak Ridge Field Office, P.O. Box 2001, Oak Ridge, TN 37831-8541

61-63. J. T. Sweeney, Department of Energy Oak Ridge Field Office, P.O. Box 2001, Oak Ridge, TN 37831-8541

64. D. W. Swindle, Radian Corporation, 120 South Jefferson Circle, Oak Ridge, TN 37830

65. H, M. Thron, Chief, Enrichment Facilities, Oak Ridge Program Division, Office of Eastern Area Programs, Office of Environmental Restoration, EM-423, Trevion 2, U.S. Department of Energy, Washington, DC 20585

66-67. Office of Scientific and Technical Information, P.O. Box 62, Oak Ridge, TN 37831 

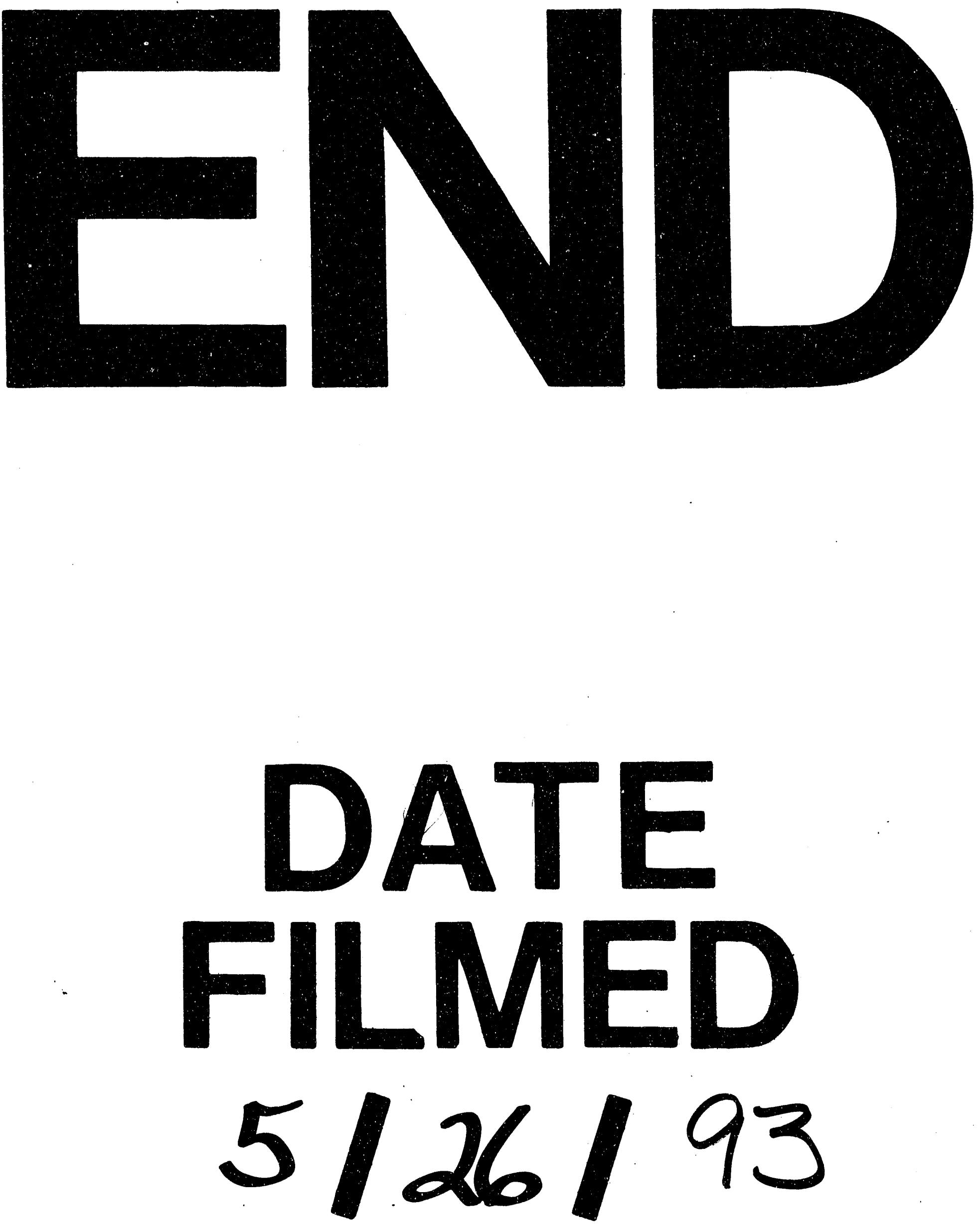

i 
